\author{
UNIVERSIDADE DE SÃO PAULO \\ INSTITUTO DE QUÍMICA DE SÃO CARLOS
}

\title{
Espectroscopias de infravermelho próximo e médio na quantificação de atributos do solo, com ênfase na matéria orgânica e na biomassa microbiana
}

Tatiana Maris Ferraresi

Orientador

Dr. Ladislau Martin Neto

São Carlos

2010 
Tatiana Maris Ferraresi

\section{Espectroscopias de infravermelho próximo e médio na quantificação de atributos do solo, com ênfase na matéria orgânica e na biomassa microbiana}

Dissertação apresentada ao Instituto de Química de São Carlos da Universidade de São Paulo, para obtenção do título de mestre em Ciências. Área de concentração: Química Analítica.

Orientador: Dr. Ladislau Martin Neto

São Carlos 2010 
Q̀ minha familia:

Liiz Antonio Ferraresi

Sirlei Rissoli fFerraresi

Seila Cristina Ferraresi

Paula Daniele Ferraresi

Dedice

Qos pesquisadores, estudankes e amantes da terra que buscam, ao mesmo tempo, cultivá-la, estudá-la e respeitá-la 


\section{AGRADECIMENTOS}

Quero agradecer a Deus por ter misericórdia de mim, aceitar-me apesar das falhas, dar-me sempre uma nova chance, amar-me infinitamente.

Quero agradecer à minha mãe Sirlei e ao meu pai Luiz, que me apoiam e querem sempre o melhor para mim. E às minhas irmãs Dani, pela ajuda nas pesquisas, e Leila pela correção gramatical e ortográfica e as duas pelo carinho. Ao Gláucio por seu auxílio como estagiário e orientador honorário e por sua companhia, paciente e confortadora, e à sua família acolhedora: Vânia, Galvão, Lucas e Nilo.

Agradeço ao Dr. Ladislau Martin Neto por me aceitar como aluna de mestrado, pela orientação e por abrir caminhos para mim. Agradeço à Embrapa Instrumentação Agropecuária, especialmente ao Dr. Wilson, por me encaminhar nas atividades, dispor da estrutura e dos equipamentos desta unidade da Embrapa para a realização deste trabalho e pela orientação. Meu agradecimento também à Joana, Renê e Marcelo. À Silviane e à Natália por me ajudarem nas análises e a resolver vários problemas. Aos amigos Úrsula, Larissa, Lívia, Lílian, Vivian, Aline, Zé Renato, Fernanda, Edilene, Lucimar, Luíza, Rafael, Poliana, Humberto, Mateus e André pelo auxílio e companhia.

Agradeço aos colegas da Embrapa Pecuária Sudeste, que me auxiliaram neste trabalho: Dr. ${ }^{a}$ Ana Rita, Dr. Gilberto, Malaguti, Cristina, Victor, Marcos, Tatiana, Jorge, Amadeu e Paulo. Obrigada pela acolhida, direcionamento, análises, coletas de solo, conversas e fotografias!!

Às minhas amigas de mestrado Regina, Malu, Catarinie, Patrícia Toniolo e ao pessoal do GOU.

À USP, uma universidade-mãe, à qual devo a minha formação como farmacêutica e para a qual retornei. A essa universidade a minha admiração e gratidão. Obrigada Instituto de Química de São Carlos, todos os seus funcionários, Silvia e Andréia da pós-graduação e Eliana bibliotecária. Agradeço também à Universidade Federal de São Carlos. Obrigada especialmente ao professor Dr. Edenir, por suas aulas extremamente didáticas e por sua disponibilidade aos alunos.

Quero agradecer à Embrapa Arroz e Feijão pela grande oportunidade, aprovando o projeto e disponibilizando os recursos necessários. Aos pesquisadores dessa unidade: Dr. a Beáta, Dr. Enderson, Dr. ${ }^{a}$ Márcia Taís e Dr. Silvando, pelos esclarecimentos e financiamentos. Aos amigos Adriana, Tatiely, Sílvio, Adriano, Cristiano, Ecion, Janne, Adilson, Luciano, Diego, Wesley, Ivã, Lorrana, Wellington, Laura, Gláucia e Melissa, que me ajudaram na realização dos experimentos e me trouxeram alegria suavizando o trabalho árduo! ’̀ Selma Koakuzu e Patrícia Valle, minhas maiores incentivadoras; sem elas eu não teria me candidatado à pós-graduação na Embrapa. $\grave{A}$ Dr. a Ana Cristina e ao Dr. Pedro Machado, que me ajudaram a pensar no projeto. Aos analistas e assistentes Márcio, Cida, Zé Francisco e Rodrigo e ao pessoal que me ajudou nas coletas de solo: Ailton, João Mula, Eric, Japão, Elídio, Tiquinho e Tião. 


\section{SUMÁRIO}

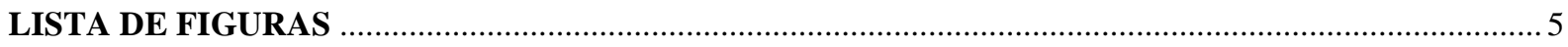

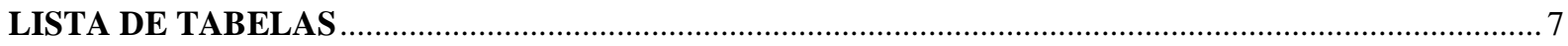

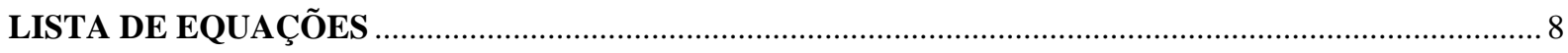

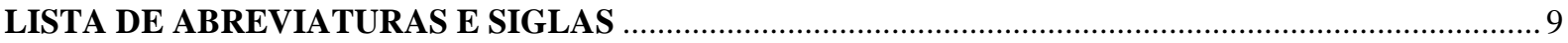

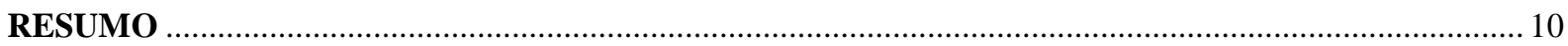

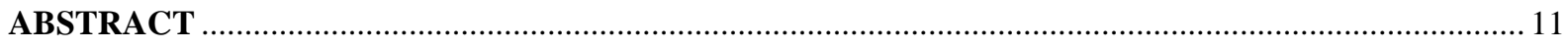

1 INTRODUÇÃ $\mathbf{O}$

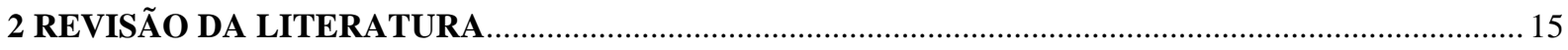

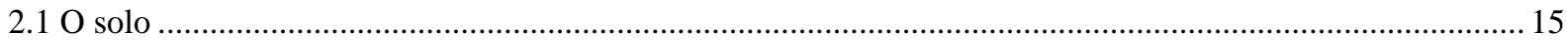

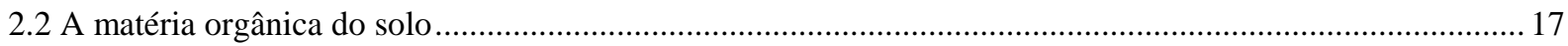

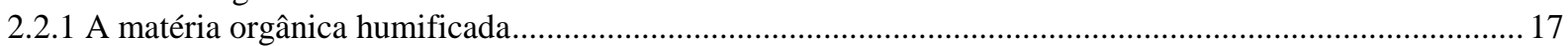

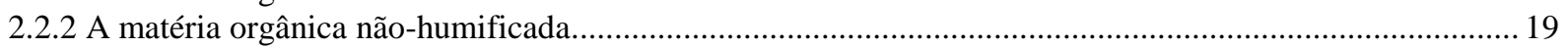

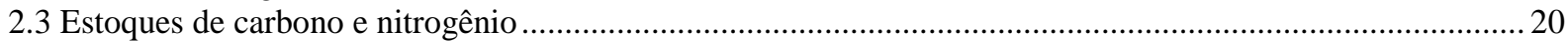

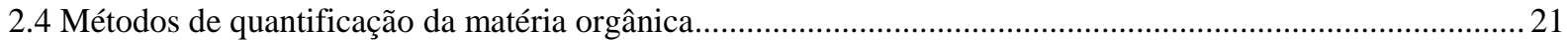

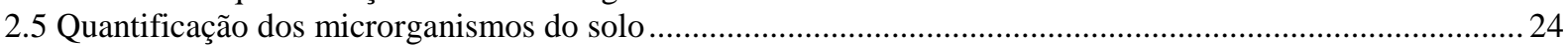

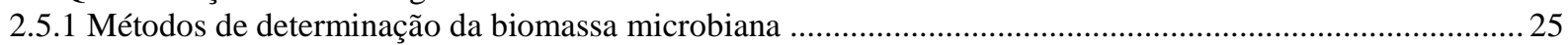

2.6 Espectroscopia .

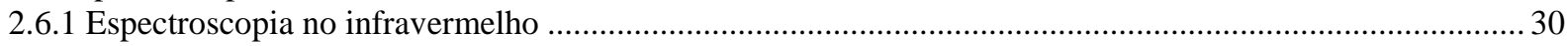

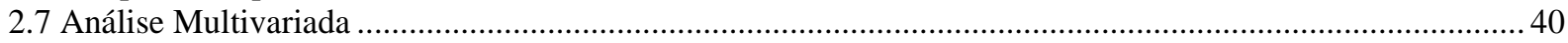

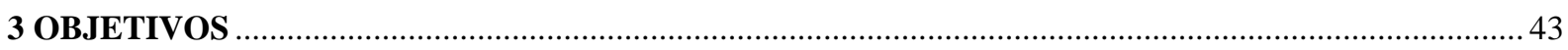

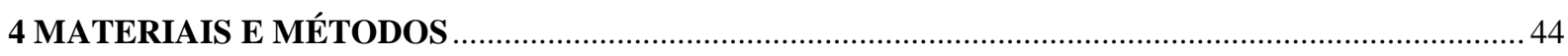

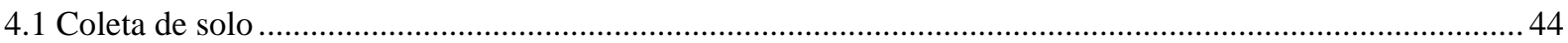

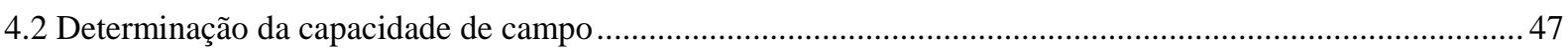

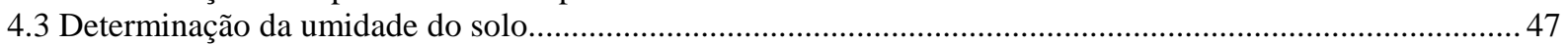

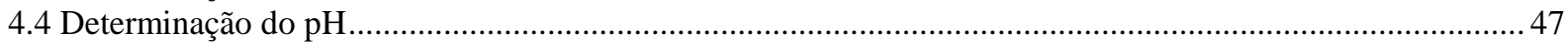

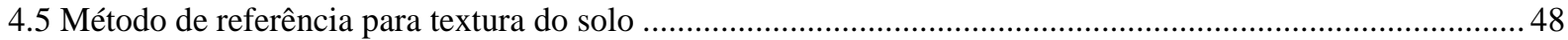

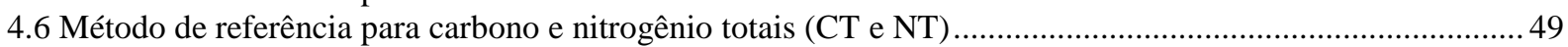

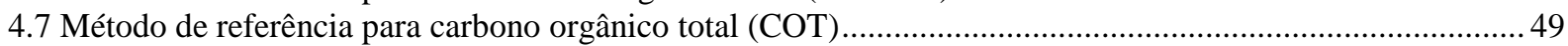

4.8 Método de referência para biomassa microbiana …………....................................................................... 50

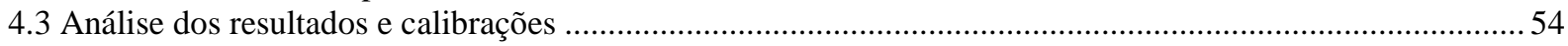

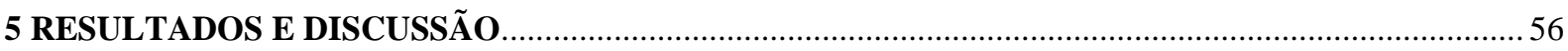

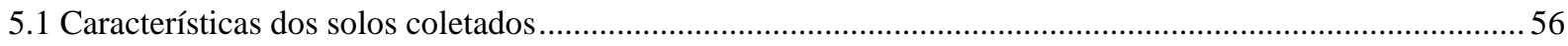

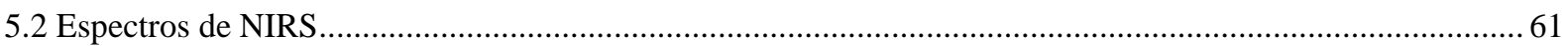

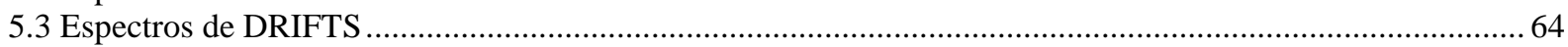

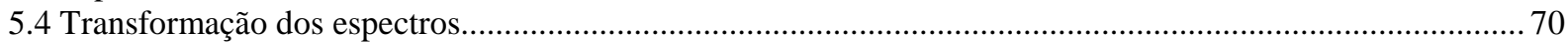

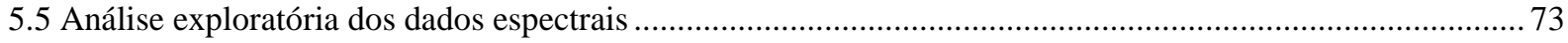

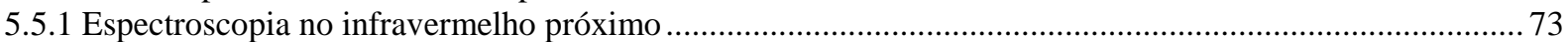

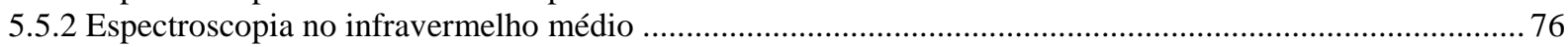

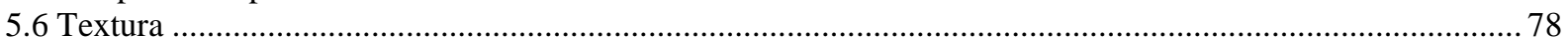

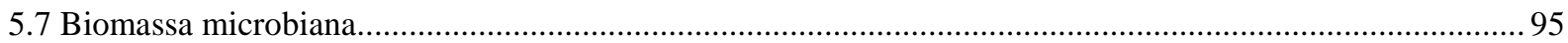

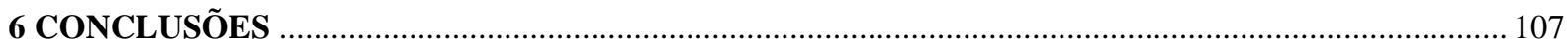

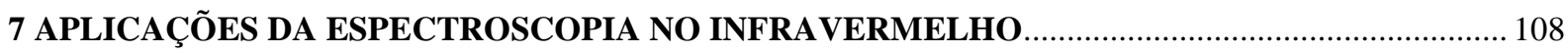

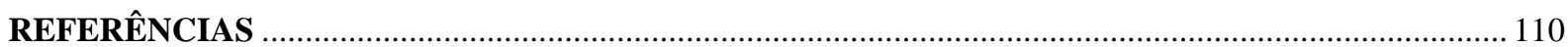




\section{LISTA DE FIGURAS}

Figura 1 Estrutura de um agregado de solo com destaque ao papel cimentante e agregador da matéria orgânica e dos microrganismos em interação com partículas de areia e argila.............................................................. 16

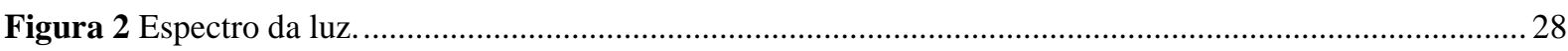

Figura 3 Relação entre níveis de energia, frequência da radiação eletromagnética e vibrações moleculares .......29

Figura 4 Tipos de vibrações das ligações em uma dada molécula ................................................................. 31

Figura 5 Modos de reflexão que ocorrem juntamente com a refletância difusa ............................................ 32

Figura 6 Esquema do interferômetro de Michelson utilizado na espectroscopia no infravermelho com transformada de Fourier.

Figura 7 Espectro no infravermelho médio de matéria orgânica do solo ..........................................................36

Figura 8 Espectros no infravermelho médio de Xylella depositada em janela silício (A) após 30 dias e (B) após

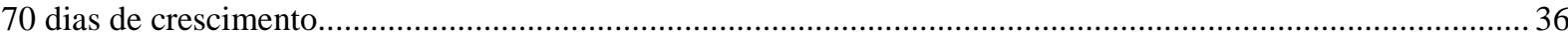

Figura 9 Espectro de NIRS de solos afetados por diferentes ocorrências de fogo. .......................................... 38

Figura 10 Croqui da área experimental da Fazenda Agroecológica da Embrapa Arroz e Feijão, Santo Antônio de

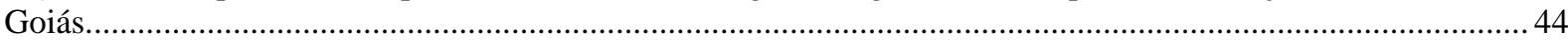

Figura 11 Mapa da fazenda experimental Capivara da Embrapa Arroz e Feijão, em Santo Antônio de Goiás. .. 45

Figura 12 Mapa da fazenda experimental Canchim da Embrapa Pecuária Sudeste, em São Carlos-SP. ............ 46

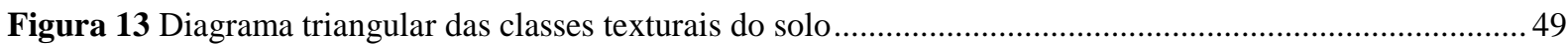

Figura 14 Quantificação da biomassa microbiana do solo pelo método de fumigação-extração ........................51

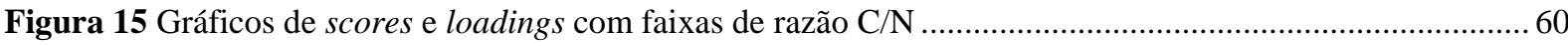

Figura 16 Espectros de absorbância em infravermelho próximo com bandas assinaladas................................61

Figura 17 Espectros de absorbância em infravermelho próximo de diferentes subgrupos amostrais, segundo uso

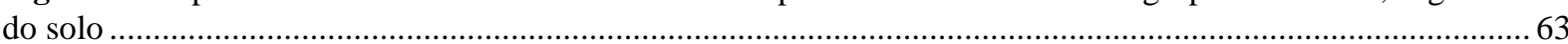

Figura 18 Espectros de absorbância em infravermelho médio com bandas assinaladas. ................................. 64

Figura 19 Espectros de absorbância em infravermelho médio de diferentes subgrupos amostrais, segundo uso do

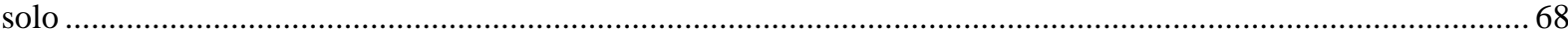

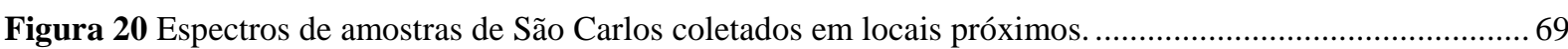

Figura 21 Espectros de solos com diferentes teores de areia e carbono orgânico. ............................................ 69

Figura 22 Espectros Absorbância e Kubelka-Munk para a amostra AF7 ...................................................... 70

Figura 23 Espectros DRIFTS da amostra PS 56 sem transformação e com o cálculo da $1^{\text {a }}$ e $2^{\text {a }}$ derivadas.......... 72

Figura 24 Gráficos de PRESS VAL e \% Variância acumulada versus número de fatores incluídos na PCA NIRS

Figura 25 Gráficos de scores (A, B e C) e de loadings (D), Fator 1 versus Fator 2 resultantes de PCAs com espectros NIRS centrados na média

Figura 26 Gráficos de PRESS VAL e \% Variância acumulada versus número de fatores incluídos na PCA DRIFTS.

Figura 27 Gráficos de scores (A, B e C) e de loadings (D), Fator 1 versus Fator 2 resultantes de PCAs com espectros DRIFTS centrados na média.

Figura 28 Gráficos de PRESS VAL e \% de variância acumulada versus número de fatores incluídos na PCA Textura.

Figura 29 Gráficos de scores e de loadings, Fator 1 versus Fator 2 resultantes de PCAs com dados autoescalados de argila, silte e areia

Figura 30 Gráficos de poder de modelagem e resíduos para os atributos Argila, Silte e Areia.

Figura 31 Gráficos dos valores medidos (de referência) versus valores preditos por modelos calculados com dados de NIRS para atributos de textura.

Figura 32 Gráficos dos valores medidos versus valores preditos por modelos calculados com dados de DRIFTS para atributos de textura. 
Figura 33 Gráfico de PRESS VAL versus número de fatores incluídos na PCA Matéria orgânica. 86

Figura 34 Gráficos de scores (A, B e C) e de loadings (D), Fator 1 versus Fator 2 resultantes de PCAs com dados auto-escalados de carbono orgânico, carbono total, nitrogênio total e razão C/N. 87

Figura 35 Gráficos apresentando poder de modelagem e resíduos associados a cada atributo componente do carbono orgânico e da análise elementar.

Figura 36 Gráficos dos valores medidos (referência) versus valores preditos, resultantes da validação cruzada (A, C e E) e da validação externa (B, D e F) de modelos calculados com dados de NIRS para atrbutos de matéria orgânica.

Figura 37 Gráficos dos valores medidos versus valores preditos, resultantes da validação cruzada (A, C e E) e da validação externa (B, D e F) de modelos calculados com dados de DRIFTS para atributos de matéria orgânica 94

Figura 38 Gráfico de PRESS VAL versus número de fatores incluídos na PCA Biomassa Microbiana. 95

Figura 39 Gráficos de scores (A, B e C) e de loadings (D), Fator 1 versus Fator 2 resultantes de PCAs com dados auto-escalados de biomassa microbiana.

Figura 40 Gráficos apresentando poder de modelagem e resíduos associados a cada atributo componente da biomassa microbiana do solo: $\mathrm{N}_{\mathrm{MIC}}, \mathrm{C}_{\mathrm{MIC}}, \mathrm{RB}, \mathrm{qCO}_{2}, \mathrm{CN}_{\mathrm{MIC}}$ e qMIC.

Figura 41 Gráficos dos valores medidos (de referência) versus valores preditos por modelos calculados com dados de NIRS para atributos da biomassa microbiana. 104

Figura 42 Gráficos dos valores medidos (de referência) versus valores preditos por modelos calculados com dados de NIRS para atributos de biomassa microbiana. 106 


\section{LISTA DE TABELAS}

Tabela 1 Tentativa de atribuição de bandas comumente encontradas em espectros de bactérias no infravermelho médio.

Tabela 2 Bandas de absorção das vibrações de estiramento dos principais grupos funcionais no espectro no infravermelho próximo $\left(\mathrm{cm}^{-1}\right)$.

Tabela 3 Classificação dos solos coletados segundo o uso do solo e a textura..................................................56

Tabela 4 Atributos do solo quantificados pelos métodos de referência............................................................5

Tabela 5 Atribuições para as bandas observadas nos espectros no infravermelho próximo..............................62

Tabela 6 Atribuições orgânicas para as bandas observadas nos espectros no infravermelho médio .....................66

Tabela 7 Atribuições inorgânicas para as bandas observadas nos espectros no infravermelho médio .................67

Tabela 8 Solos com diferentes teores de areia e carbono orgânico............................................................. 70

Tabela 9 Comparação entre modelos de calibração calculados com espectros NIRS em A e K-M .....................71

Tabela 10 Variância dos dados espectrais de NIRS explicada para as 10 PCs e erros de calibração e validação da

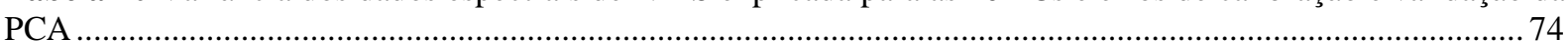

Tabela 11 Variância dos dados espectrais de DRIFTS explicada pelas 10 PCs e erros de calibração e validação

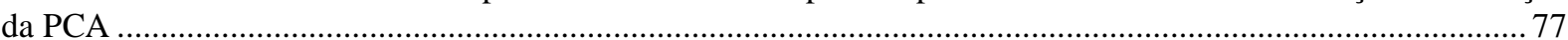

Tabela 12 Variância dos dados de textura explicada pelas 3 PCs e erros de calibração e validação da PCA ...... 79

Tabela 13 Dados de validação cruzada e externa para os modelos de calibração em NIRS e DRIFTS para Argila . 81

Tabela 14 Dados de validação cruzada e externa para os modelos de calibração em NIRS e DRIFTS para Silte82

Tabela 15 Dados de validação cruzada e externa para os modelos de calibração em NIRS e DRIFTS para Areia

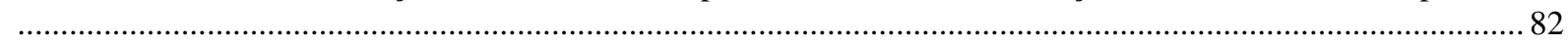

Tabela 16 Valores medidos de referência e preditos pelo modelo MATAS NIRS para Argila, Silte e Areia......83

Tabela 17 Variância dos dados de matéria orgânica explicada pelas 3 PCs e erros de calibração e validação da

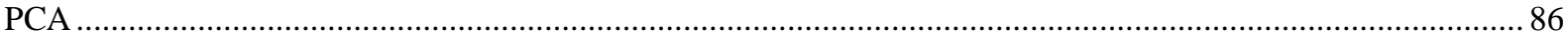

Tabela 18 Dados de validação cruzada e externa para os modelos de calibração em NIRS e DRIFTS para COT

Tabela 19 Dados de validação cruzada e externa para os aos modelos de calibração em NIRS e DRIFTS para CT

Tabela 20 Dados de validação cruzada e externa para os aos modelos de calibração em NIRS e DRIFTS para NT

Tabela 21 Dados de validação cruzada e externa para os modelos de calibração em NIRS e DRIFTS para C/N 90 Tabela 22 Valores medidos de referência e preditos pelos modelos CNPAF DRIFTS (COT E CT) E MATAS. 91

Tabela 23 Variância dos dados de biomassa microbiana explicada pelas 6 PCs e erros de calibração e validação da PCA

Tabela 24 Dados de validação cruzada e externa para os modelos de calibração em NIRS e DRIFTS para $C_{\text {MIC }} 98$

Tabela 25 Dados de validação cruzada e externa para os modelos de calibração em NIRS e DRIFTS para $\mathrm{N}_{\text {MIC }}$

Tabela 26 Dados de validação cruzada e externa para os modelos de calibração em NIRS e DRIFTS para RB .98

Tabela 27 Dados de validação cruzada e externa para os modelos de calibração em NIRS e DRIFTS para qCO

Tabela 28 Dados de validação cruzada e externa para os modelos de calibração em NIRS e DRIFTS para C/N $\mathrm{N}_{\text {MIC }}$

Tabela 29 Dados de validação cruzada e externa para os modelos de calibração em NIRS e DRIFTS para qMIC

Tabela 30 Valores medidos de referência e preditos pelos modelos CNPAF DRIFTS $\left(\mathrm{C}_{\text {MIC }}\right.$ e $\left.\mathrm{N}_{\text {MIC }}\right)$ e MATAS 


\section{LISTA DE EQUAÇÕES}

Equação 1 Reação de oxidação da matéria orgânica por dicromato de potássio em meio ácido..........................22

Equação 2 Reação de titulação do dicromato de potássio com sulfato ferroso ................................................22

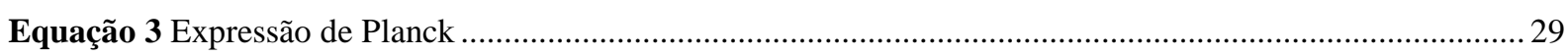

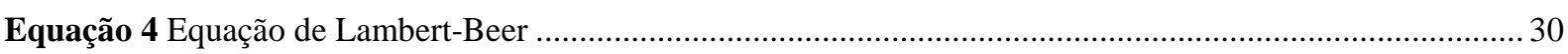

Equação 5 Equação de Kubelka-Munk ................................................................................................. 32

Equação 6 Equação de transformação de dados de reflectância para absorbância ..............................................33

Equação 7 Equação de regressão com vários comprimentos de onda derivada da equação de Lambert-Beer..... 40

Equação 8 Relação entre concentração e dados ópticos ............................................................................. 41

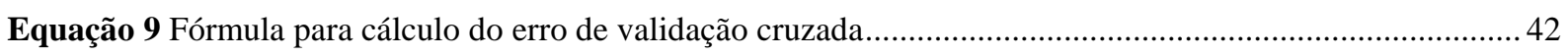

Equação 10 Fórmula para cálculo do erro percentual médio da validação externa..............................................42

Equação 11 Fórmula para cálculo da umidade do solo .......................................................................47

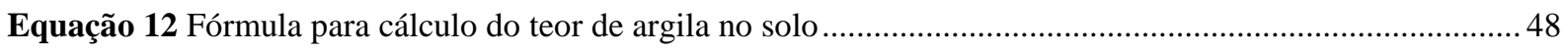

Equação 13 Fórmula para cálculo do teor de areia no solo .......................................................................48

Equação 14 Fórmula para cálculo do teor de silte no solo .......................................................................48

Equação 15 Fórmula para cálculo do teor de carbono orgânico total no solo ...................................................50

Equação 16 Reação de captura do $\mathrm{CO}_{2}$ pela solução de hidróxido de potássio................................................50

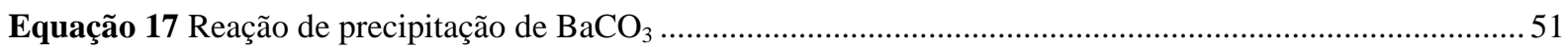

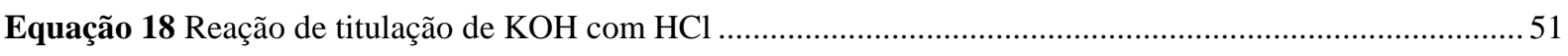

Equação 19 Fórmula para a determinação da respiração basal do solo........................................................52

Equação 20 Fórmula para o cálculo do teor de carbono microbiano no solo .....................................................53

Equação 21 Fórmula para o cálculo do teor de nitrogênio microbiano no solo.................................................53 


\section{LISTA DE ABREVIATURAS E SIGLAS}

$\mathrm{C}_{\mathrm{MIC}}$

$\mathrm{CN}$ total

$\mathrm{CN}_{\mathrm{MIC}}$

CNPAF

COT

CPPSE

CT

CTC

$\mathrm{CV}$

DRIFTS

FTIR

IARC

$\mathrm{Kc}$

MO

MOS

NIRS

$\mathrm{N}_{\text {MIC }}$

NT

$\mathrm{PC}$

PCA

PLS

PRESS VAL

$\mathrm{qCO}_{2}$

qMIC

RVC

RVE

SEV

$\mathrm{SH}$

TOC

VIS

Y FIT
Carbono microbiano

Razão CT / NT

Razão $\mathrm{C}_{\mathrm{MIC}} / \mathrm{N}_{\mathrm{MIC}}$

Centro Nacional de Pesquisa em Arroz e Feijão

Carbono orgânico total

Centro Nacional de Pesquisa em Pecuária Sudeste

Carbono total

Capacidade de troca de cátions

Coeficiente de variação

Diffuse reflectance Fourier Transformed Spectroscopy

Espectroscopia no infravermelho com Transformada de Fourier

International Agency for Research on Cancer

Constante de velocidade da reação de mineralização de carbono

Matéria orgânica

Matéria orgânica do solo

Near Infrared Spectroscopy

Nitrogênio microbiano

Nitrogênio total

Componente principal

Analise de componentes principais

Cálculo dos mínimos quadrados parciais

Soma dos quadrados dos erros de validação cruzada

Quociente metabólico

Quociente microbiano

Coeficiente de regressão obtido com validação cruzada

Coeficiente de regressão obtido com validação externa

Erro de validação cruzada

Substâncias húmicas

Total organic carbon

Região do espectro da luz correspondente à faixa visível

Ajuste dos dados preditos à linha identidade com dados de referência 


\title{
Espectroscopia no infravermelho próximo e médio na quantificação de atributos do solo, com ênfase na matéria orgânica e na biomassa microbiana
}

Autora: Tatiana Maris Ferraresi

Orientador: Dr. Ladislau Martin Neto

\begin{abstract}
RESUMO
A matéria orgânica e a biomassa microbiana do solo consistem em sensíveis indicadores de qualidade do solo e de seus estoques de carbono e nitrogênio que, juntamente com a textura, têm auxiliado na escolha de formas de manejo agronômico mais sustentáveis. Os métodos disponíveis para a determinação da matéria orgânica (Walkley-Black modificado da EMBRAPA SOLOS, 1997) e da biomassa microbiana (Vance et al., 1987a) têm sido largamente utilizados, porém possuem alguns inconvenientes como a geração de resíduos altamente tóxicos e a grande demanda de tempo para analisar um pequeno número de amostras. A espectroscopia, por sua vez, tem se mostrado uma alternativa mais rápida e limpa para a identificação e quantificação de compostos orgânicos. Por esse motivo, este trabalho teve como objetivo testar métodos espectroscópicos, tanto no infravermelho próximo (NIRS) quanto no médio com refletância difusa (DRIFTS), com o uso de calibração multivariada, para a quantificação destes indicadores. Os teores de argila, silte, areia, carbono orgânico total e carbono microbiano, assim como o quociente microbiano $\left(\mathrm{C}_{\mathrm{MIC}} / \mathrm{COT}\right)$, foram espectrometricamente preditos de modo satisfatório. Em geral, obtiveram-se melhores resultados utilizando DRIFTS.
\end{abstract}




\title{
Near and Mid-infrared spectroscopy for quantification of soil attributes focusing organic matter and microbial biomass
}

\author{
Author: Tatiana Maris Ferraresi \\ Adviser: Dr. Ladislau Martin Neto
}

\begin{abstract}
Organic matter and microbial biomass are sensible ways to indicate soil quality as well as carbon and nitrogen stocks. These properties, added to clay, silt and sand contents, have been helped to choose sustainable agronomic soil managements. Current methods for organic matter (Walkley-Black modified by EMBRAPA SOLOS, 1997) and microbial biomass (Vance et al., 1987a) determinations have been widely used despite the generation of toxic waste and large time requirement for analyzing a small number of samples. Spectroscopy, in turn, has been shown a clean and rapid alternative method for this purpose. Thus, the aim of the study was to evaluate the near-infrared reflectance spectroscopy (NIRS) and the midinfrared diffuse reflectance spectroscopy (DRIFTS) on soil organic matter, microbial biomass and texture determination. Clay, silt, sand, total organic carbon and microbial carbon contents as even as microbial quotient are accurately quantified by infrared spectroscopy. In general, DRIFTS provided better results.
\end{abstract}




\section{INTRODUÇÃO}

O Brasil tem uma grande variedade de solos - mais de 30 tipos de acordo com o IBGE (2005, Anexo I) - a maioria com grande aptidão agrícola, somando uma área de pelo menos 200 milhões de hectares de terras agricultáveis (LIMA; CAPOBIANCO, 2009; RODRIGUES, 2009). Desde os primórdios da colonização, a agricultura é a principal atividade econômica do país, sendo responsável ainda por $25 \%$ do Produto Interno Bruto, o que torna o Brasil candidato a "celeiro do mundo" ( ${ }^{1}$ CERRI, 2009; ${ }^{2}$ FRANÇA, 2009).

Tendo em vista a sua importância econômica e também social, a agricultura necessita cada vez mais estabelecer estratégias de manejo adequado do solo e da biodiversidade que considerem sua aptidão e potencial de uso (LEONARDO, 2003).

O emprego de processos agrícolas intensivos em insumos energéticos - como fertilizantes, mecanização (ex. aração e gradagem), irrigação e pesticidas - provoca, direta e indiretamente, um aumento da emissão de gases de efeito estufa. Além disso, as práticas de ocupação de terras e transformação do uso e cobertura vegetal, como desmatamentos e queimadas, também contribuem para grande parte dessas emissões (EMBRAPA SOLOS, 2009).

Na mesma velocidade e amplitude em que ocorrem as transformações ambientais e climáticas, cresce a demanda por indicadores de qualidade. A expectativa é que eles permitam monitorar e, de alguma forma, antever os danos, a fim de evitar impactos negativos ao meio ambiente. A partir do conhecimento de tais consequiências, é possível selecionar práticas que mantenham maiores estoques de matéria orgânica no solo e que reduzam a emissão de gases de efeito estufa.

\footnotetext{
1 Informação fornecida por: TRAVELIN, C. Agricultura de baixo carbono, $2009 . \quad$ Disponível em: <http://mercadoetico.terra.com.br/arquivo/agricultura-de-baixo-carbono>. Acesso em: 21 jan. 2010.

2 Informação fornecida por: COSTA, N. Embrapa e o "celeiro do mundo", 2009. Disponível em: <http://www.alerta.inf.br/agropecuaria/1504.html>. Acesso em: 21 jan. 2010.
} 
Por sua sensibilidade e correlação com a fertilidade e estrutura de agregados do solo, a matéria orgânica e sua fração viva predominante, a biomassa microbiana, tornam-se elegíveis como indicadores da qualidade do solo, com grande utilidade no monitoramento das mudanças nos estoques de carbono (ISLAM; WEIL, 2000). Entretanto, os métodos atualmente utilizados para esta quantificação não oferecem resultados satisfatórios quanto à confiabilidade e precisão. Ademais, envolvem experimentos demorados e de difícil execução quando se trata de um número grande de amostras.

Nesse contexto, a espectroscopia de refletância difusa nas regiões do infravermelho próximo (NIRS) e infravermelho médio (DRIFTS) tem sido indicada para a análise de solos por ser um método não destrutivo, rápido e de custo baixo (VISCARRA-ROSSEL et al., 2006). Tal tipo de espectroscopia permite uma ampla caracterização da matéria orgânica, detectando vários compostos em uma mesma análise. Desde 1995 (BEM-DOR; BANIN, 1995), a espectroscopia no infravermelho tem ganhado muita atenção na quantificação de componentes de solos, como carbono total (CT) (MCCARTY et al., 2002), carbono orgânico (COT) (MADARI et al., 2005, 2006a), carbono inorgânico (MCCARTY et al., 2002; CHANG; LAIRD, 2002), carbono microbiano ( $\left.\mathrm{C}_{\mathrm{MIC}}\right)$ e nitrogênio microbiano ( $\left.\mathrm{N}_{\mathrm{MIC}}\right)$ (REEVES III; MCCARTY, 2001; JANIK et al., 1998).

Ao contrário das análises químicas convencionais, as análises espectroscópicas não implicam o uso intensivo de reagentes químicos - em sua maioria tóxicos à saúde humana e ao meio ambiente - e, consequentemente, não produzem resíduos de difícil tratamento que se tornam um passivo ambiental.

Atualmente, já existem vários trabalhos publicados (CHANG et al., 2001; LUDWIG et al., 2002; COÛTEAUX et al., 2003; MADARI et al., 2005; MADARI et al., 2006; VISCARRA-ROSSEL et al., 2006) que tiveram como objetivo desenvolver bibliotecas de espectros e calibrações em infravermelho para a quantificação das propriedades do solo. No 
entanto, poucos deles relacionam a espectroscopia com a atividade biológica do solo (COÛTEAX et al., 2003).

A possibilidade de utilizar técnicas espectroscópicas em substituição aos métodos convencionais de determinação da biomassa microbiana depende do desenvolvimento de modelos preditivos, que têm sido propostos não só para este parâmetro, mas também para a respiração do solo, e ajustados para algumas atividades enzimáticas (COÛTEAUX et al., 2003).

MADARI et al. (2005, 2006a), usando NIRS e DRIFTS, obtiveram bons resultados nas calibrações para carbono total e orgânico de solos brasileiros. No entanto, não foram encontrados relatos na literatura de calibrações para carbono e nitrogênio da biomassa microbiana em solos brasileiros.

Com o enfoque voltado para a manutenção e melhoria da qualidade do solo e o incremento eficiente no estoque de carbono, as pesquisas envolvendo técnicas de manejo (como plantio direto, agricultura orgânica, integração lavoura-pecuária e sistemas agroflorestais) necessitam de suporte na sua avaliação temporal e espacial, após uso de diversos manejos do solo, espécies culturais e adubação verde. Tais estudos requerem a análise de um grande número de amostras para cada área avaliada.

Dessa forma, o advento e o aperfeiçoamento das técnicas espectroscópicas para análises quantitativas vêm demonstrando seu potencial em auxiliar no entendimento dos processos relacionados com a dinâmica da matéria orgânica, após ação antrópica no sistema, significando agregação de qualidade e rapidez aos estudos. 


\section{REVISÃO DA LITERATURA}

\subsection{0 solo}

O solo, juntamente com os fatores edáficos, é a base de sustentação da pedosfera, onde se distribuem os ecossistemas (MOREIRA; SIQUEIRA, 2006), sendo capaz de suportar grande parte da vida da Terra, especialmente a espécie humana. Consiste no maior reservatório de elementos e substâncias que supre as necessidades nutricionais de plantas e animais e de onde provém alimentos, fibras, materiais para construção de habitações e equipamentos (ESSINGTON, 2004). Aliás, o solo funciona como uma máquina recicladora, recebendo restos de seres mortos e resíduos de atividades urbanas e agrícolas (MOREIRA; SIQUEIRA, 2006).

Os solos brasileiros estão localizados, em sua maioria (73\%), na região do bioma Cerrado, a uma altitude entre 300 e 900 metros, sendo o latossolo o tipo predominante (46\%). Esses solos são profundos, bem estruturados, com alta porosidade, considerados de grande potencial agrícola para produção de culturas anuais e perenes e também para pastagens (FERREIRA, M. et al., 1999; RESCK et al., 2008; EBERHARDT et al., 2008).

O solo é composto, além de porções de ar e água, de uma fração mineral e uma orgânica, sendo a primeira, que geralmente corresponde a $45 \%$ em solos minerais, constituída majoritariamente de elementos como silício, alumínio e ferro em diferentes formas: sílica $\mathrm{SiO}_{2}$, alumina $\mathrm{Al}_{2} \mathrm{O}_{3}$, magnetita $\mathrm{Fe}_{2} \mathrm{O}_{4}$, hematita $\mathrm{Fe}_{2} \mathrm{O}_{3}$, goetita $\mathrm{FeO}(\mathrm{OH})$, caulinita $\mathrm{Al}_{2} \mathrm{SiO}_{5}(\mathrm{OH})_{4}$, gibbsita $\mathrm{Al}_{2} \mathrm{O}_{3} \cdot 3 \mathrm{H}_{2} \mathrm{O}$, vermiculita $(\mathrm{MgFe}, \mathrm{Al})_{3}(\mathrm{Al}, \mathrm{Si})_{4} \mathrm{O}_{10}(\mathrm{OH})_{2} \cdot 4 \mathrm{H}_{2} \mathrm{O} \quad$ e montmorilonita $\mathrm{M}_{\mathrm{x}}\left(\mathrm{Al}_{4-\mathrm{x}} \mathrm{Mg}_{\mathrm{x}}\right) \mathrm{Si}_{8} \mathrm{O}_{20}(\mathrm{OH})$ (ESSINGTON, 2004). Alguns desses são argilominerais, que, em associação com a matéria orgânica, formam as partículas de argila, ao passo que a sílica (tetraedros de dióxido de silício) pode se organizar na forma de cristais de quartzo, material resistente à decomposição, constituindo partículas de areia. 
Os minerais do solo também podem ser classificados em termos de tamanho de partícula (diâmetro médio): areia $(>1 \mathrm{~mm})$, silte $(1 \mathrm{~mm}$ a $56 \mu \mathrm{m})$ e argila $(<56 \mu \mathrm{m})$. A distribuição relativa dessas partículas no solo é denominada textura (MARCOLIN, 2006).

A textura dos latossolos brasileiros é principalmente argilosa, sendo a caulinita, a gibbsita, a goethita e a hematita, minerais com baixa capacidade de troca de cátions (CTC), os principais minerais da fração argila desses solos (FERREIRA, M. et al.1999).

O arranjo das partículas do solo e o espaço poroso formado entre elas resultam em agregados com forma e tamanho variáveis: os microagregados (com diâmetro menor que $250 \mu \mathrm{m}$ ) e os macroagregados (com diâmetro maior que $250 \mu \mathrm{m}$ ). Acredita-se que um solo adequado para o crescimento de plantas deva conter agregados com diâmetro entre 1 e 10 mm, que permaneçam estáveis quando molhados e contenham grande quantidade de poros com mais de $75 \mu \mathrm{m}$ de diâmetro, para permitir a aeração, e alguns poros com 20-30 $\mu \mathrm{m}$, para reter água. O processo de agregação envolve a ação de fatores bióticos e abióticos, como pode ser observado através da estrutura de um agregado (MOREIRA; SIQUEIRA, 2006).

A Figura 1 ilustra o papel exercido pela matéria orgânica (MOS) e pelos microrganismos na qualidade estrutural do solo, promovendo a adesão das partículas com produção de substâncias cimentantes, como os polissacarídeos de alta viscosidade e as substâncias húmicas (CANELLAS et al, 2008; MOREIRA; SIQUEIRA, 2006).

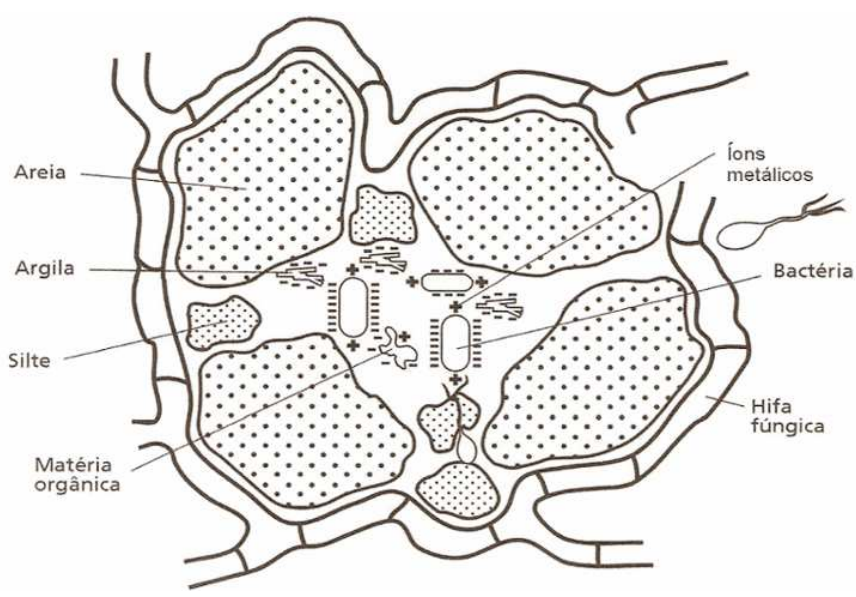

Figura 1 Estrutura de um agregado de solo com destaque ao papel cimentante e agregador da matéria orgânica e dos microrganismos em interação com partículas de areia e argila. Fonte: Moreira e Siqueira, 2008. 


\subsection{A matéria orgânica do solo}

Algumas propriedades do solo influenciadas pelo teor de matéria orgânica são: a estabilidade dos agregados, a disponibilidade de nutrientes e a retenção de água no solo. Solos com textura média a argilosa, moderadamente drenados e com alta atividade microbiana, geralmente apresentam grande quantidade de agregados estáveis. Estes agregados, por sua vez, protegem fisicamente a matéria orgânica, e, juntamente com os óxidos de ferro (que se associam quimicamente a ela), constitui fator que contribui para os estoques de MOS (ANJOS et al., 2008).

O preparo inadequado do solo para o plantio com o uso de gradagem, queimadas e desmatamento destroi os macroagregados, expõe a MOS à oxidação, aumenta a emissão de gases de efeito estufa como $\mathrm{CO}_{2}, \mathrm{CH}_{4}, \mathrm{NO}_{2}$, ocasiona a perda de umidade, elimina parte da biomassa microbiana e rompe o equilíbrio dos ciclos de nutrientes. Por outro lado, sistemas conservacionistas como o plantio direto, integração de lavouras e agroflorestas utilizam um revolvimento mínimo do solo e permitem um contínuo aporte de matéria orgânica ao solo, mantendo os serviços ecológicos prestados pelos organismos vivos e contribuindo para a preservação da qualidade desses recursos e sustentabilidade da produção agrícola (MOREIRA; SIQUEIRA, 2006; BOT; BENITES, 2005).

A matéria orgânica do solo engloba os resíduos vegetais em estágios variados de decomposição, a biomassa microbiana, a fauna, as raízes e a fração mais estável, denominada húmus (BAYER; MIELNICZUK, 2008). Do total de 5\% representado pelo conteúdo orgânico do solo, a maior parte é composta de substâncias recalcitrantes que formam o húmus e o restante corresponde à MOS prontamente mineralizável (CERRI, 2008).

\subsubsection{A matéria orgânica humificada}

O húmus consiste na matéria orgânica morta e decomposta, que já sofreu vários processos de hidrólise, oxidação, redução e síntese pelos microrganismos. As substâncias 
húmicas $(\mathrm{SH})$ possuem estruturas complexas, ainda não totalmente conhecidas, envolvendo ácidos carboxílicos, fenólicos, aromáticos e alifáticos anfifílicos. Durante o processo de humificação, ocorre um aumento de compostos aromáticos e uma redução de ligações C-O de carboidratos, característica que contribui para a resistência à biodegradação do húmus (SEGNINI, 2007).

De acordo com a solubilidade em soluções ácidas e alcalinas, as SH são divididas operacionalmente em ácidos húmicos, ácidos fúlvicos e humina. A extração do húmus do solo com hidróxido de sódio $0,5 \mathrm{~mol} \mathrm{~L}^{-1}$ solubiliza as frações ácido fúlvico e ácido húmico, enquanto que a humina permanece no solo (ESSINGTON, 2004). As frações remanescentes na solução, em seguida, são separadas pela precipitação dos ácidos húmicos em meio ácido.

A reatividade química das $\mathrm{SH}$ pode ser medida pela sua acidez total, calculada pela soma de grupamentos carboxílicos $(\mathrm{COOH})$ e fenólicos $(\mathrm{Ar}-\mathrm{OH})$. Os hidrogênios dos grupos $\mathrm{COOH}$ são dissociados a partir de $\mathrm{pH}$ 3,0 no solo, enquanto que a desprotonação das hidroxilas fenólicas ocorre em torno de $\mathrm{pH} 9,0$, sendo esses dois grupos responsáveis por 95\% da acidez das SH. A presença de cargas variáveis confere às substâncias húmicas a habilidade de participar de grande parte das reações do solo (CANELLAS et al., 2008).

A capacidade de troca de cátions (CTC) da matéria orgânica aumenta com a elevação do pH, em função da ionização dos grupos ácidos citados. Em comparação com alguns minerais de argila como caulinita $\left(3-5 \mathrm{cmol}_{\mathrm{c}} \mathrm{Kg}^{-1}\right.$ - centimol de carga por quilograma) e montmorilonita $\left(80-150 \mathrm{cmol}_{\mathrm{c}} \mathrm{Kg}^{-1}\right)$, as $\mathrm{SH}$ apresentam CTC que varia de 400 a $1400 \mathrm{cmol}_{\mathrm{c}}$ $\mathrm{Kg}^{-1}$ (CANELLAS et al., 2008).

Em solos mais intemperizados, as substâncias húmicas contribuem de forma significativa para a densidade de cargas negativas de superfície. Em solos antigos que possuem um alto teor de argila, o maior conteúdo da fração ácidos fúlvicos explica sua contribuição mais significativa para a CTC nesses solos (CANELLAS et al., 2008). 
Essas características das SH explicam a grande influência da matéria orgânica em funções vitais para o solo, como a absorção e retenção de água, retenção de calor e controle do pH pelo efeito tampão ocasionado por essas substâncias.

\subsubsection{A matéria orgânica não-humificada}

A fração mais lábil da MOS é composta por moléculas bem conhecidas como aminoácidos, carboidratos, proteínas, ácidos orgânicos, que estão presentes principalmente nos organismos vivos: na fauna (10\%) e nos microrganismos como fungos (50\%), bactérias e actinomicetos (30\%), leveduras, algas, protozoários e nematóides (10\%) (CERRI, 2008). Portanto, a maior parte da matéria orgânica viva é representada pela biomassa microbiana, definida como o somatório de todos os organismos do solo menores que $5 \times 10^{3} \mu \mathrm{m}^{3}$, incluindo, além de fungos e bactérias, as leveduras, os actinomicetos e alguns protozoários (JENKINSON; LADD, 1981).

Produtos do metabolismo de microrganismos no solo, tais como ácidos orgânicos e inorgânicos, substâncias alcalinas (amônia ou aminas) e polissacarídeos extracelulares, além de cátions ligantes, são os principais responsáveis pelo intemperismo de silicatos e aluminosilicatos presentes nas rochas. A contribuição da MOS e da atividade microbiana na gênese dos latossolos se dá, essencialmente, através da produção de ácido carbônico $\left(\mathrm{H}_{2} \mathrm{CO}_{3}\right)$, promovendo uma dissolução maior de silício em relação ao ferro e alumínio (ANJOS et al., 2008).

Substâncias de baixa massa molar como os monômeros provenientes da catálise enzimática de macromoléculas, realizada no meio extracelular, são absorvidas e metabolizadas pelos organismos microbianos. Esta é a última etapa da decomposição da matéria orgânica denominada mineralização, pois resulta em produtos inorgânicos como $\mathrm{CO}_{2}$, $\mathrm{NH}_{3}, \mathrm{NO}_{3}{ }^{-}, \mathrm{H}_{2} \mathrm{PO}_{4}^{-}, \mathrm{HPO}_{4}{ }^{2-}$ e $\mathrm{SO}_{4}{ }^{2-}$, os quais podem ser utilizados pelas plantas e pelos próprios microrganismos (MOREIRA; SIQUEIRA, 2006). 
O fluxo de elementos como carbono $(\mathrm{C})$, nitrogênio $(\mathrm{N})$, fósforo $(\mathrm{P})$ e enxofre $(\mathrm{S})$ ocorre através do sistema solo-água-planta-atmosfera, compondo alternadamente moléculas bióticas e abióticas dentro dos chamados ciclos biogeoquímicos (FEIDEN, 2005). As transformações dos elementos estão fortemente ligadas às transformações do carbono orgânico, o que explica em parte alterações sofridas por esses ciclos pela influência do clima e pela ação antrópica (MOREIRA; SIQUEIRA, 2006).

\subsection{Estoques de carbono e nitrogênio}

No processo de fotossíntese, os vegetais assimilam o dióxido de carbono $\left(\mathrm{CO}_{2)}\right.$ e, na presença de minerais e água, transformam esse gás em biomassa vegetal. Em média 58\% dessa biomassa é carbono (C), que compõe as folhas, caules, frutos e raízes (RESCK et al., 2008).

A quantidade de carbono orgânico no solo é uma função do balanço entre a velocidade de deposição de resíduos vegetais e a velocidade de mineralização desses resíduos pela biota (BALDOCK; NELSON, 1999). Em geral, há duas vezes mais carbono no solo do que a soma das quantidades encontradas na atmosfera $\left(7 \times 10^{14} \mathrm{Kg}\right)$ e na biomassa vegetal $\left(4,8 \times 10^{14} \mathrm{Kg}\right)$ (BOLIN; COOK, 1983).

Nos latossolos, os teores de carbono orgânico situam-se na faixa de 2 a $5 \mathrm{~g} \mathrm{Kg}^{-1}$; já em organossolos, o teor mínimo é de $80 \mathrm{~g} \mathrm{Kg}^{-1}$ de solo (EMBRAPA SOLOS, 2006).

O nitrogênio também está presente no solo, preferencialmente na forma orgânica (BOLIN; COOK, 1983). Por esse motivo, a MOS é considerada uma reserva de nitrogênio para solos agrícolas. $\mathrm{O}$ teor de $\mathrm{N}$ em latossolos varia de 1,1 a $1,8 \mathrm{~g} \mathrm{Kg}^{-1}$ na camada de 0-15 cm (RESCK et al., 2008).

O nitrogênio é um dos nutrientes mais limitantes para o crescimento de plantas e animais no sistema terrestre e aquático. Apesar de este elemento estar presente em grandes concentrações nas rochas, sedimentos e na atmosfera, a sua disponibilidade em formas viáveis 
para os organismos vivos é limitada (BOLIN; COOK, 1983; CAMARGO et al., 2008).

A biodisponibilidade do nitrogênio depende da mineralização exercida pela atividade microbiana, cuja taxa é medida pela produção de amônio e nitrato. As reações de amonificação e nitrificação transformam, em média, de $2 \%$ a $5 \%$ do $\mathrm{N}$ orgânico por ano. A predominância do $\mathrm{N}$ orgânico no balanço de nitrogênio no solo se deve, principalmente, à elevada resistência de alguns compostos orgânicos nitrogenados como aminoácidos, peptídeos e proteínas ao ataque microbiano. Estes compostos se encontram, muitas vezes, estabilizados por reações com ligninas, taninos, quinonas e açúcares redutores. A adsorção por partículas de argila também os protege da ação das proteinases (CAMARGO et al., 2008).

A presença de materiais resistentes à decomposição no solo é caracterizada por uma alta razão $\mathrm{C} / \mathrm{N}(>30)$. À medida que o resíduo orgânico é mineralizado, parte do carbono é liberado e esta relação diminui, disponibilizando mais nitrogênio, que é ao mesmo tempo imobilizado pelos microrganismos. A biomassa microbiana contribui muito para a demanda de N, sendo sua razão C/N em média 10:1 (MOREIRA; SIQUEIRA, 2006).

\subsection{Métodos de quantificação da matéria orgânica}

A quantificação da matéria orgânica do solo normalmente é feita a partir da determinação, em laboratório, do conteúdo de carbono orgânico (COT). A fórmula comumente empregada é: M.O. $\left(\mathrm{g} \mathrm{Kg}^{-1}\right)=1,724$ x COT, face ao conceito de que o teor de carbono da matéria orgânica do solo é igual a 58\% desta (EMBRAPA SOLOS, 1997). Entretanto, apesar de sua ampla aplicação, este fator varia conforme determinadas características do solo (CONCEIÇÃO et al., 1999). Resultados encontrados na literatura indicam fatores variando de 1,55 a 2,13 (JACKSON, 1982). Avaliações feitas por Broadbent (1953) indicam valores de 1,9 para amostras superficiais de solos e 2,5 para subsolos.

O método de Walkley-Black modificado (JACKSON, 1982), inserido no Manual de Métodos de Análise de Solo (EMBRAPA SOLOS, 1997), consiste na oxidação do carbono 
orgânico do solo pelo cromo na forma de $\mathrm{Cr}^{6+}$, na presença de ácido sulfúrico concentrado, na qual o excesso de $\mathrm{Cr}^{6+}$ é titulado com $\mathrm{Fe}^{2+}$ (CONCEIÇÃO et al., 1999). As reações de oxidação e titulação são apresentadas nas Equações 1 e 2, respectivamente (ESSINGTON, 2004).

$$
\begin{aligned}
& 1,5 \mathrm{CH}_{2} \mathrm{O}(s)+\mathrm{Cr}_{2} \mathrm{O}_{7}{ }^{2-}(a q)+8 \mathrm{H}^{+}(a q) \rightarrow 1,5 \mathrm{CO}_{2}+2 \mathrm{Cr}^{3+}(a q)+5,5 \mathrm{H}_{2} \mathrm{O}(l) \text { (Equação 1) } \\
& \mathrm{Cr}_{2} \mathrm{O}_{7}{ }^{2-}(a q)+6 \mathrm{Fe}^{2+}(a q)+14 \mathrm{H}^{+}(a q) \rightarrow 2 \mathrm{Cr}^{3+}(a q)+6 \mathrm{Fe}^{3+}(a q)+7 \mathrm{H}_{2} \mathrm{O}(l) \text { (Equação 2) }
\end{aligned}
$$

Este método é ainda hoje o mais empregado em laborátorios de solos devido à simplicidade e ao baixo custo, porém apresenta problemas analíticos e ambientais, devido ao uso de cromo, que é um metal tóxico solúvel de comprovado efeito cancerígeno, classificado no grupo I pela IARC (International Agency for Research on Cancer) (TERRA FILHO; SATOSHI, 2006).

O procedimento, com abertura da amostra por via úmida, também não é capaz de detectar as formas de carbono do solo que se encontram mais protegidas ou complexadas com a fração mineral do solo, ocorrendo apenas uma oxidação parcial da matéria orgânica (SEGNINI et al., 2008). Já na determinação do conteúdo total de carbono (CT) geralmente são recuperadas todas as formas de carbono orgânico e inorgânico, convertendo-as, em seguida, para dióxido de carbono $\left(\mathrm{CO}_{2}\right)$ por meio de combustão seca ou úmida. $\mathrm{O}^{\mathrm{CO}_{2}}$ liberado é quantificado por meio de técnicas gravimétricas, titulométricas, volumétricas, espectrométricas ou cromatográficas (SILVA et al., 1999).

Tais métodos alternativos são relativamente rápidos, mas também apresentam problemas de exatidão (SEGNINI et al., 2008). O método da mufla, por exemplo, tem a vantagem de ser simples, mas está suscetível a erros de quantificação devido à decomposição de caulinita e de óxidos, como a gibbsita e a goetita, juntamente com a matéria orgânica (TABATABAI, 1996; MADARI; REEVES, 2008; SCHUMACHER, 2002).

A metodologia de quantificação de carbono orgânico total (TOC) em amostras líquidas 
e sólidas por combustão é uma análise rápida, altamente reprodutível e facilmente automatizada (SEGNINI et al., 2008). Entretanto, outro método, semelhante ao TOC, é considerado atualmente como padrão internacional, no qual se utiliza um analisador elementar que quantifica o $\mathrm{CO}_{2}$ desprendido a partir da combustão de amostras sólidas, usando $\mathrm{O}_{2}$ atmosférico, a temperaturas superiores a $950^{\circ} \mathrm{C}$. Um catalisador converte o $\mathrm{CO}$ em $\mathrm{CO}_{2}$ e sua quantificação é feita por meio de um detector de condutividade térmica (SILVA et al., 1999).

A utilização de analisadores elementares automáticos trouxe avanços consideráveis, permitindo análises rápidas e confiáveis. Contudo, os custos de cada análise e da manutenção dos equipamentos são elevados (SEGNINI et al., 2008).

Em experimento realizado por Segnini et al. (2008), com o objetivo de comparar diversos métodos de quantificação da matéria orgânica do solo, concluiu-se que, dentre os métodos Walkley-Black, TOC e Análise Elementar, o TOC apresentou desvios menores. De acordo com os autores, isso pode ser explicado pelo fato de que no método TOC utiliza-se uma maior massa comparada à análise elementar, além de promover uma oxidação mais eficiente quando comparado com o método Walkley-Black. Outra explicação pode ser que o detector de infravermelho acoplado ao TOC seja mais sensível ao $\mathrm{CO}_{2}$ do que o detector por condutividade térmica utilizado pelo analisador elementar. A especificidade do primeiro pode ser uma vantagem, porém o segundo se torna mais versátil, sendo útil na quantificação de outros elementos simultaneamente.

Segundo Nelson e Sommers (1996), frações orgânicas resistentes, como carvão presente no solo e parte da humina, não são oxidados pelo dicromato de potássio. A oxidação parcial da MOS pelo método de Walkley-Black fez com que os valores obtidos por Segnini et al. (2008) fossem em média 22,9 e 17,7\% menores que aqueles observados via TOC e Análise Elementar, respectivamente. 


\subsection{Quantificação dos microrganismos do solo}

Os primeiros métodos utilizados na quantificação de microrganismos do solo consistiam na contagem direta do número de células em meios de cultura e o cálculo da biomassa era realizado através da determinação dos volumes celulares e da densidade média das estruturas vivas.

A quantificação da população microbiana nos solos tem sido feita tradicionalmente com base no isolamento dos microrganismos em meios de cultura. Esse método fornece informações sobre os grupos de microrganismos viáveis e cultiváveis em uma amostra de solo, mas tende a selecionar populações com taxas de reprodução mais elevadas em meios de cultura com altas concentrações de nutrientes e em condições aeróbias. Da mesma forma, fungos com alta capacidade de produção de esporos também são favorecidos (LAMBAIS et. al, 2005; KIRK et al., 2004).

Várias outras limitações metodológicas estão associadas à cultura de microrganismos in vitro, como: dificuldades em desalojar microrganismos associados a biofilmes e partículas do solo, condições ótimas para crescimento e interações negativas entre as colônias de microrganismos (LAMBAIS et. al, 2005; KIRK et al., 2004).

A microscopia direta dessas células também é possível, mas raramente utilizada em amostras naturais de solo devido à dificuldade operacional e maior tempo de execução dos procedimentos. Entretanto, é útil quando se comparam diferentes metodologias para aferição da biomassa (DE-POLLI; GUERRA, 2008).

A dificuldade para discriminação entre microrganismos vivos e mortos torna-se uma limitação, visto que na estimativa da biomassa microbiana do solo deve ser considerada a massa viva de microrganismos, além de ser difícil diferenciar partículas microscópicas do solo de células microbianas (DE-POLLI; GUERRA, 2008). Na impossibilidade da obtenção de uma medida quantitativa exata da população microbiana total em um ecossistema, por 
métodos culturais ou por microscopia direta, foram desenvolvidos outros métodos capazes de avaliar a massa dos microrganismos (CARDOSO, 2004).

\subsubsection{Métodos de determinação da biomassa microbiana}

A quantificação da biomassa microbiana foi descrita primeiramente por Jenkinson e Powlson (1976), que utilizaram o método de incubação após fumigação de amostras de solo com vapor de clorofórmio. Este processo ocasiona o rompimento das células presentes e, em seguida, a sua decomposição por aquelas sobreviventes à fumigação ou por novas células provenientes de inóculo de solo fresco. Os procedimentos envolvem a medida da emanação do dióxido de carbono nas amostras fumigadas, assim como em amostras testemunhas nãofumigadas, após 10 dias de incubação. O carbono microbiano pode ser estimado dividindo-se esse valor por um fator de mineralização do carbono (Kc), que pode variar de acordo com a proporção de fungos e bactérias, com a idade dos organismos e com a umidade das amostras de solo.

Existe uma marcante influência dos fatores ambientais neste método, principalmente porque a taxa de mineralização é muito dependente das condições da incubação, como temperatura, umidade e natureza do solo. Ademais, esse método não é recomendado para solos ácidos porque se torna necessário o uso de um inóculo grande e, consequentemente, a utilização de outro fator de correção para a mineralização do carbono da sua própria biomassa (VANCE et al., 1987b; CARDOSO, 2004).

A respiração basal, valor obtido da medição de dióxido de carbono durante um período de incubação sem a prévia fumigação nem inoculação, reflete a atividade microbiana (BALOTA et al., 1998). A quantidade de carbono da biomassa microbiana correlaciona-se bem com a evolução do $\mathrm{CO}_{2}$ liberado pela respiração, conforme observado por Conceição et al. (2005). O método proposto por Anderson e Domsch (1978) baseia-se nesta correlação entre respiração e biomassa para calcular o carbono microbiano por meio da transformação da 
taxa máxima de respiração inicial após adição de glicose. $\mathrm{O} \mathrm{CO}_{2}$ liberado pode ser medido (1) pela adição de frasco contendo um volume conhecido de solução alcalina, como hidróxido de sódio ou de potássio, juntamente com as amostras durante a incubação, ou (2) através de cromatógrafo gasoso com detecção em infravermelho, método rápido e conveniente, segundo Sparling e Ross (1993), para solos com pH acima de 6,5.

A quantidade de glicose requerida para ativar a máxima taxa respiratória inicial varia grandemente, dependendo das propriedades físicas e químicas dos solos, devendo ser determinada para cada tipo de solo (CARDOSO et al., 2004; LIN; BROOKES, 1999; FISK et al., 2003). Entretanto, a principal desvantagem do método de respiração induzida está relacionada com o processo de conversão de $\mathrm{CO}_{2}$ em $\mathrm{C}_{\mathrm{MIC}}$, cujo fator e curva podem variar sensivelmente em diferentes tipos de solo (CARDOSO et al., 2004; GRISI, 1997; JENKINSON; LADD, 1981).

Segundo Balota et al. (1998), a quantidade de $\mathrm{CO}_{2}$ liberado por unidade de biomassa microbiana em determinado tempo denomina-se quociente metabólico, expresso em $\left(\mu \mathrm{g} \mathrm{CO}_{2}\right)$ $\left(\right.$ mg $\left.\mathrm{C}_{\text {MIC }}{ }^{-1}\right) \mathrm{h}^{-1}$. Este quociente mede a taxa de metabolização da matéria orgânica pelos microrganismos, sendo considerado importante na avaliação dos efeitos das condições ambientais sobre a população microbiana do solo (ANDERSON; DOMSCH, 1993).

Para Insam e Domsch (1988), o quociente metabólico diminui em agroecossistemas mais estáveis; porém, com a substituição da cobertura vegetal, ocorre decomposição mais acelerada dos resíduos vegetais e ele tende a aumentar. Maiores valores são encontrados em condições ambientais estressantes, nas quais a biomassa microbiana utiliza mais carbono para sua manutenção. Segundo Gama-Rodrigues (2008), à medida que a biomassa microbiana se torna mais eficiente, menos carbono é perdido como $\mathrm{CO}_{2}$ pela respiração e uma fração significativa de carbono é incorporada ao tecido microbiano. Por esse motivo, solos com baixo quociente metabólico estão próximos ao estado de equilíbrio (SOUZA et al. 2006). 
Tanto o método fumigação-incubação quanto a respiração induzida por glicose utilizam a taxa de mineralização, ou seja, transformação do carbono orgânico em $\mathrm{CO}_{2}$, para o cálculo do carbono microbiano. Esta taxa é muito dependente das condições da incubação, como temperatura, umidade e natureza do solo.

Vance et al. (1987a) minimizaram essas influências ambientais obtendo extratos de solo com sulfato de potássio $0,5 \mathrm{~mol} \mathrm{~L}^{-1}$ após a fumigação. Esse método é particularmente útil em solos ácidos e orgânicos de florestas e em solos secos reidratados, onde o método de fumigação-incubação mostra limitações (WARDLE, 1994). A extração direta das amostras fumigadas e não-fumigadas não sofre interferência das condições ambientais, pois não depende do crescimento microbiano como o método fumigação-incubação. Além disso, é possível quantificar não só o carbono microbiano, mas também outros elementos importantes como nitrogênio, fósforo e enxofre. Entretanto, este método está sujeito à variabilidade da eficiência da extração e do rompimento das células na fumigação.

A quantificação do carbono orgânico extraído pode ser realizada por dicromatometria, método mais comum, espectrofotometria em ultravioleta ou com o uso de analisador de carbono solúvel. Já o nitrogênio presente nos extratos pode ser determinado através do método Kjeldahl, empregando o procedimento destilação/titulação, ou por análise de injeção em fluxo com leitura da absorbância no visível, sendo o primeiro mais utilizado. $\mathrm{O}_{\mathrm{MIC}} \mathrm{e}$ $\mathrm{N}_{\text {MIC }}$ são calculados subtraindo-se o valor das amostras fumigadas das não-fumigadas.

A técnica titulométrica denominada dicromatometria, utilizada tanto para a quantificação do carbono orgânico total quanto para o carbono da biomassa microbiana do solo, resulta em resíduo prejudicial à saúde e ao meio ambiente e de difícil tratamento em escala laboratorial. Da mesma forma, a quantificação de nitrogênio orgânico total e microbiano pelo método Kjeldahl implica problemas ambientais, pois envolve o uso de solução altamente alcalina e uma digestão sulfúrica a altas temperaturas. Além disso, o 
método Kjeldahl, apesar de muito preciso, consome muito tempo (NOGUEIRA; SOUZA; BATISTA, 1996).

Pode-se calcular a razão entre o carbono e o nitrogênio microbianos, assim como a razão $\mathrm{C} / \mathrm{N}$ no solo, o que fornece informações sobre as espécies que compõem essa biomassa e seu estágio de amadurecimento. Jenkinson e Ladd (1981) relataram que fungos e bactérias possuem razões $\mathrm{C} / \mathrm{N}$ consideravelmente diferentes. As hifas fúngicas possuem normalmente razão $\mathrm{C} / \mathrm{N}$ na faixa de 10 a 12, enquanto que nas bactérias este valor varia entre 3 e 5 . Assim, uma alta relação $\mathrm{C} / \mathrm{N}$ indica uma predominância de fungos na biomassa microbiana e viceversa (IBOMCHA, 2006; CAMPBELL, 1991).

\subsection{Espectroscopia}

Newton, em 1666, observou o espectro da luz visível, correspondente ao arco-íris, através de um experimento de separação dos seus componentes com um prisma. Esta visualização corresponde a apenas uma parte do espectro eletromagnético (BARBOSA, 2007), como pode ser observado na Figura 2.

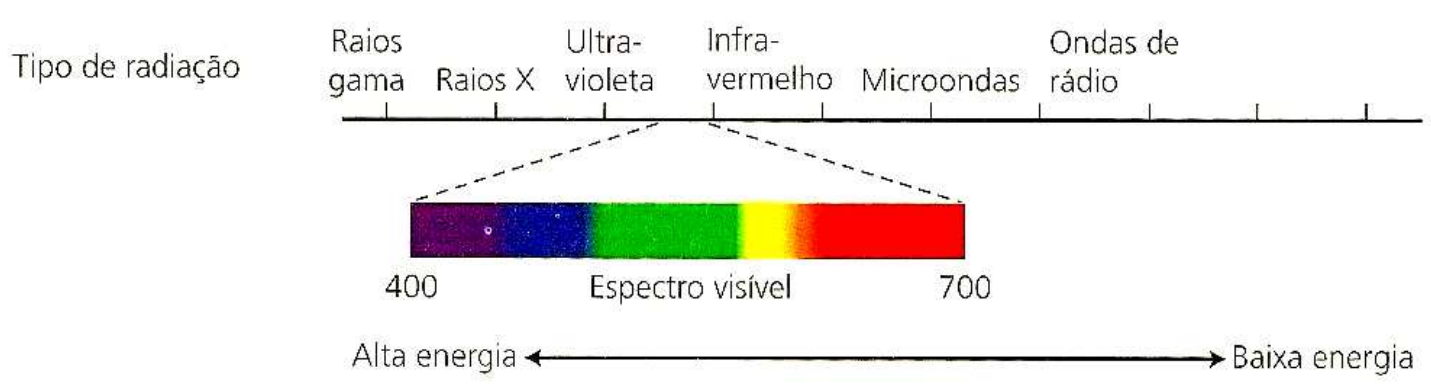

Figura 2 Espectro da luz. Adaptada de: Taiz e Zeiger, 2009.

Trabalhos de Planck, Bohr e Einstein demonstraram que a onda eletromagnética expressa o movimento de fótons de energia. De acordo com a expressão de Planck (Equação 3), cada comprimento de onda carrega uma quantidade discreta de energia (BARBOSA, 2007). 


$$
\mathrm{E}=\mathrm{hc} \lambda^{-1} \text { (Equação 3) }
$$

onde:

$$
\begin{aligned}
& \mathrm{E}=\text { energia luminosa de um fóton }(\mathrm{J}) \\
& \mathrm{c}=\text { velocidade da luz }\left(3 \times 10^{8} \mathrm{~m} \mathrm{~s}^{-1}\right) \\
& \mathrm{h}=\text { constante de Planck }\left(6,63 \times 10^{-34} \mathrm{~J} \mathrm{~s}^{-1}\right) \\
& \lambda=\text { comprimento de onda }(\mathrm{m})
\end{aligned}
$$

Assim, a luz pode interagir de diversas formas com os elementos e moléculas, sendo cada faixa de frequência relacionada com um nível de complexidade da matéria devido aos níveis de energia (Figura 3).

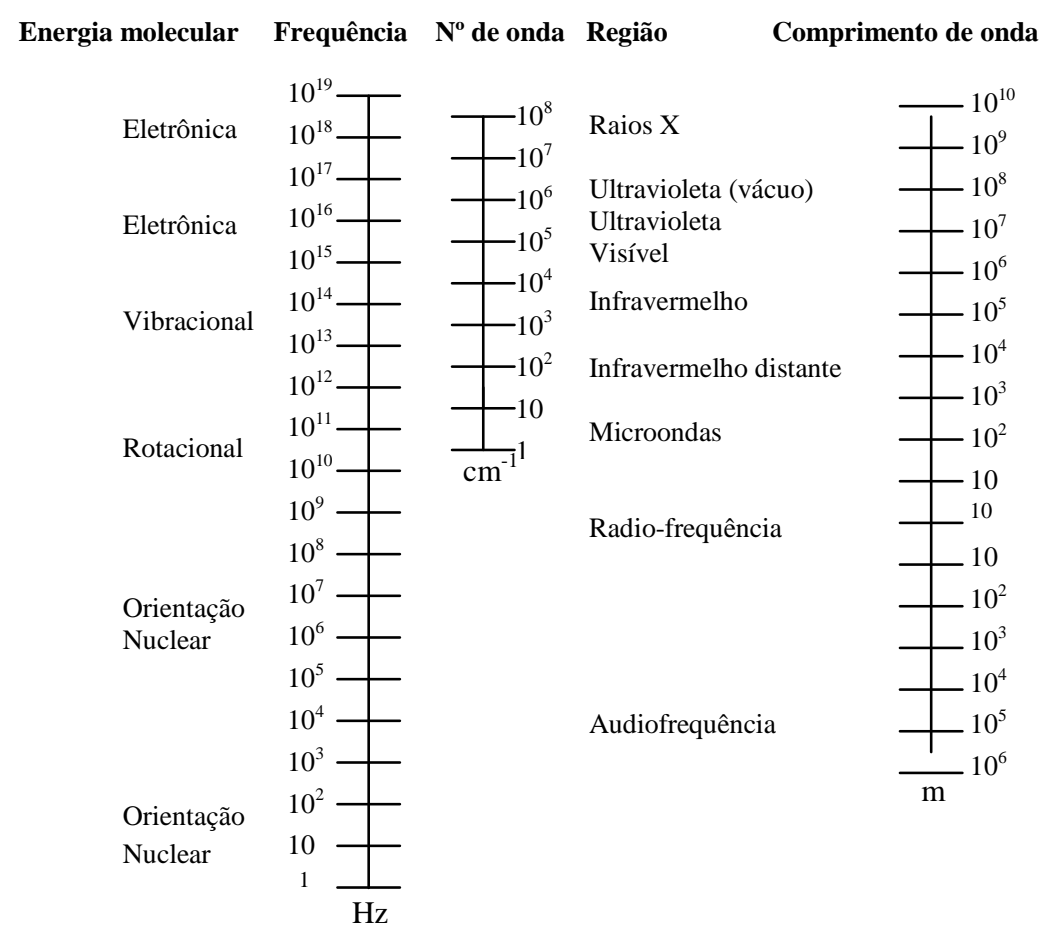

Figura 3 Relação entre níveis de energia, frequência da radiação eletromagnética e vibrações moleculares. Traduzida de: Whiffen, 1972.

O termo espectroscopia envolve o estudo dessa interação entre a radiação eletromagnética com a matéria. O comportamento das massas, submetidas à ação das ondas eletromagnéticas, também segue uma razão quantizada como apresentado pela lei de BeerLambert. Essa característica, expressa na Equação 4, onde a absorbância da luz por uma 
substância está correlacionada com a concentração desta em determinado material, permite mensurar algumas propriedades de diferentes compostos.

$$
\mathrm{A}=-\log \left(\mathrm{I} / \mathrm{I}_{0}\right)=-\log (\mathrm{T})=\varepsilon \mathrm{cl}(\text { Equação 4) }
$$

onde:

$$
\begin{aligned}
& \mathrm{A}=\text { absorbância } \\
& \mathrm{I}=\text { intensidade da luz transmitida } \\
& \mathrm{I}_{0}=\text { intensidade da luz incidente } \\
& \mathrm{T}=\text { transmitância } \\
& \varepsilon=\text { coeficiente de extinção molar }\left(\mathrm{L} \mathrm{mol}^{-1} \mathrm{~cm}^{-1}\right) \\
& \mathrm{c}=\text { concentração da substância absorvente }\left(\mathrm{mol} \mathrm{L}^{-1}\right) \\
& \mathrm{l}=\text { comprimento do caminho óptico em }(\mathrm{cm})
\end{aligned}
$$

A relação da concentração com a absorbância é linear, porém com a transmitância não. A lei de Beer-Lambert é a base para a análise quantitativa por espectroscopia (WORKMAN, 1998).

\subsubsection{Espectroscopia no infravermelho}

Diferentemente das radiações nas regiões do ultravioleta e do visível, que, ao incidirem sobre uma molécula, causam transições eletrônicas, a radiação infravermelha promove alterações nos modos rotacionais e vibracionais das moléculas (BARBOSA, 2007). Por meio desta técnica espectroscópica podem ser observadas as oscilações do eixo (estiramentos) e do ângulo (deformações) das ligações entre os átomos de um grupamento funcional. Esses grupamentos podem ser identificados no espectro desde que apresentem um momento dipolo (diferença de polaridade entre os átomos de uma molécula), como, por exemplo, aqueles contendo oxigênio, largamente presente na matéria orgânica (CANELLAS et al., 2001). Os diversos tipos de vibrações moleculares são ilustrados na Figura 4. 

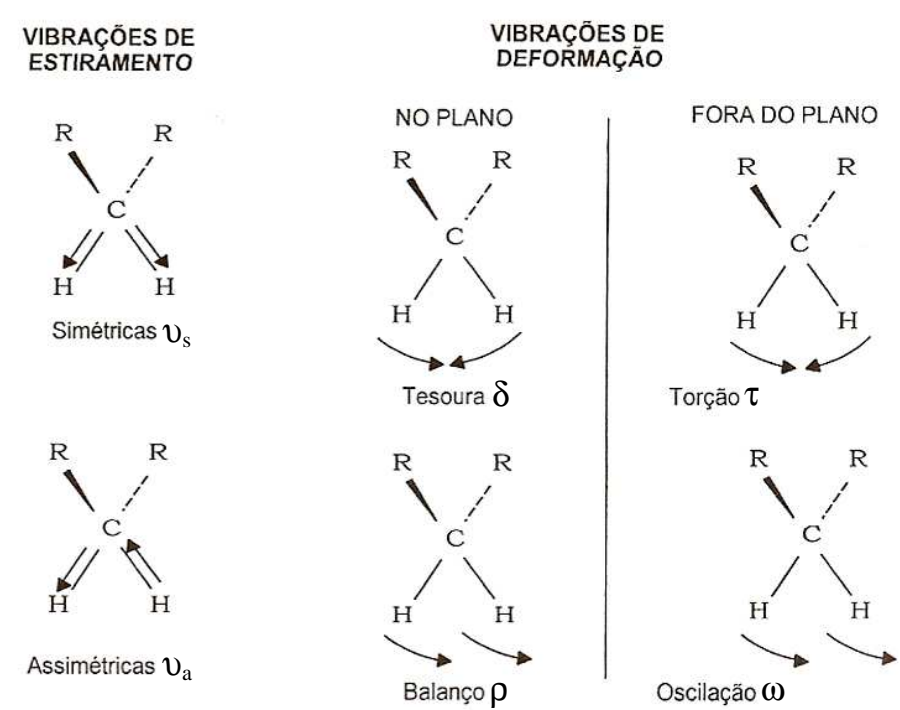

Figura 4 Tipos de vibrações das ligações em uma dada molécula. Fonte: Ceretta et al., 2008.

Por ser capaz de refletir no espectro as características moleculares da amostra, os resultados obtidos com essa espectroscopia são considerados verdadeiras impressões digitais, no caso de substâncias puras. Entretanto, não somente substâncias puras, mas também células intactas, contendo no seu interior moléculas de DNA/RNA, proteínas, lipídeos, carboidratos, entre outras, podem ser analisadas (FILIP; HERMANN, 2001).

A espectroscopia no infravermelho por transmissão é um método tradicional em análise qualitativa, para o qual existem várias técnicas de preparo de amostra como diluição em brometo de potássio $(\mathrm{KBr})$, preparação de filmes com aquecimento e pressão ou pastilhas de $\mathrm{KBr}$. Porém, estas técnicas envolvem o uso de altas pressões e podem afetar a amostra com a produção de interferências químicas (KOENING, 1992). Alternativamente, métodos de reflexão podem ser aplicados, eliminando as etapas de preparação das amostras, que envolvem tempo e uso de solventes tóxicos.

Ao incidir na amostra, a luz pode ser refletida como num espelho (refletância especular), de forma difusa ou por uma combinação dessas duas maneiras, refletindo difusamente na superfície. Esses modos de reflexão podem ser visualizados na Figura 5. 


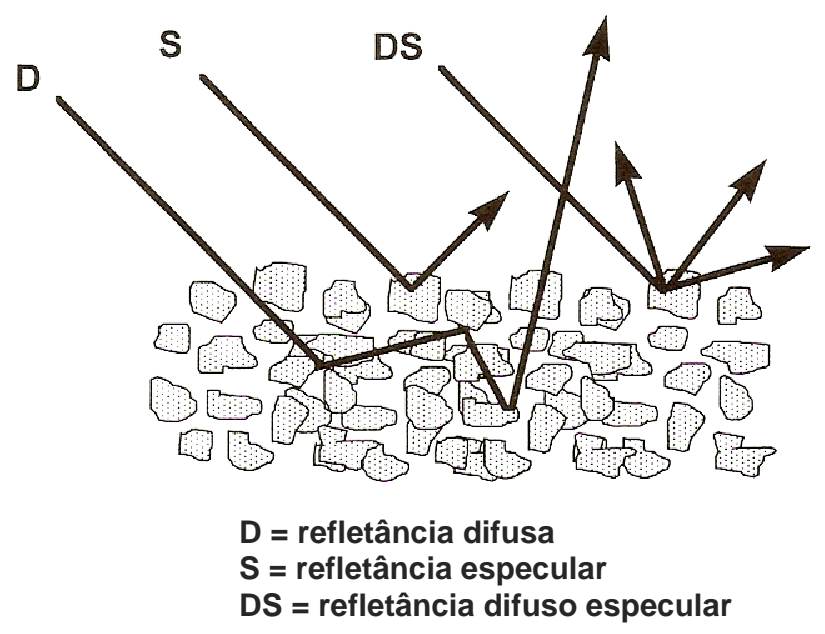

Figura 5 Modos de reflexão que ocorrem juntamente com a refletância difusa. Traduzida de: Coates, 1998.

No espectro proveniente da medida da refletância difusa, em contraste com o espectro tradicional de transmitância, não há uma correlação direta entre a intensidade do pico e a composição. As distorções são geradas por uma variação constante do caminho óptico, definido pela penetração da radiação na amostra, que é dependente da sua absortividade em cada freqüência de onda (COATES, 1998). A correção que pode ser aplicada ao espectro de refletância difusa para linearizar os dados é a função de Kubelka-Munk ou K-M (COATES, 1998, BARBOSA, 2007). Nesta equação (5), assume-se que a amostra tem uma espessura infinitamente pequena se comparada à profundidade de penetração da radiação na amostra.

onde:

$$
\mathrm{f}\left(\mathrm{R}_{\infty}\right)=\left(1-\mathrm{R}_{\infty}\right)^{2} \times\left(2 \mathrm{R}_{\infty}\right)^{-1}=2,303 \mathrm{ac} \times \mathrm{s}^{-1} \text { (Equação 5) }
$$

$\mathrm{f}\left(\mathrm{R}_{\infty}\right)=$ espectro corrigido

$\mathrm{R}_{\infty}=$ razão entre o espectro de refletância difusa da amostra e o do material não absorvente de referência $(\mathrm{KCl}$ ou $\mathrm{KBr})$

$\mathrm{a}=$ absortividade

$\mathrm{c}=$ concentração do analito

$\mathrm{s}=$ coeficiente de espalhamento 
Esta equação (5) inverte o espectro de refletância e transforma-o em um formato parecido com o espectro de absorbância. Esta correção só pode ser aplicada às amostras não diluídas com haletos (COATES, 1998).

Outra possibilidade que tem sido aceita nos últimos anos é a simples transformação dos dados de refletância (R) para absorbância (A), considerando-os equivalentes aos valores de transmitância (T) (Equação 6).

$$
\mathrm{A}=-\log \mathrm{T}=-\log \mathrm{R}(\text { Equação 6) }
$$

Para se obter espectros de pós, sólidos e espécies adsorvidas nos sólidos, a técnica de refletância difusa é a mais indicada. Além de reduzir o tempo de preparação, obtêm-se informações de materiais na forma mais próxima da original. O potencial da técnica foi reconhecido como um novo método de análise quantitativa, mas a obtenção de bons resultados depende de uma boa pulverização da amostra, pois o tamanho e a forma das partículas, o espaço livre entre elas e o grau de compactação afetam a concentração do material através do qual a radiação é transmitida (COATES, 1998; MESSERSCHMIDT, 1999).

Até algumas décadas atrás, as técnicas quantitativas no infravermelho eram pouco usadas devido às seguintes desvantagens: bandas sobrepostas, desvio da lei de Beer sob uma larga faixa de concentração, irreprodutibilidade da linha de base, ruídos instrumentais elevados e baixa sensibilidade. Com o advento do algoritmo da transformada rápida de Fourier e sua aplicação à espectroscopia no infravermelho (FTIR), algumas dessas desvantagens foram vencidas (BLANCO et al., 1995; MARK; WORKMAN, 2003). O FTIR possibilitou a utilização de equipamentos mais modernos associados ao interferômetro de Michelson (Figura 6), em substituição aos equipamentos dispersivos, e proporcionou um aumento da relação sinal-ruído, ao permitir acumular vários espectros em poucos segundos, 
além de uma maior entrada de energia em relação aos instrumentos dispersivos (BARBOSA, 2007).

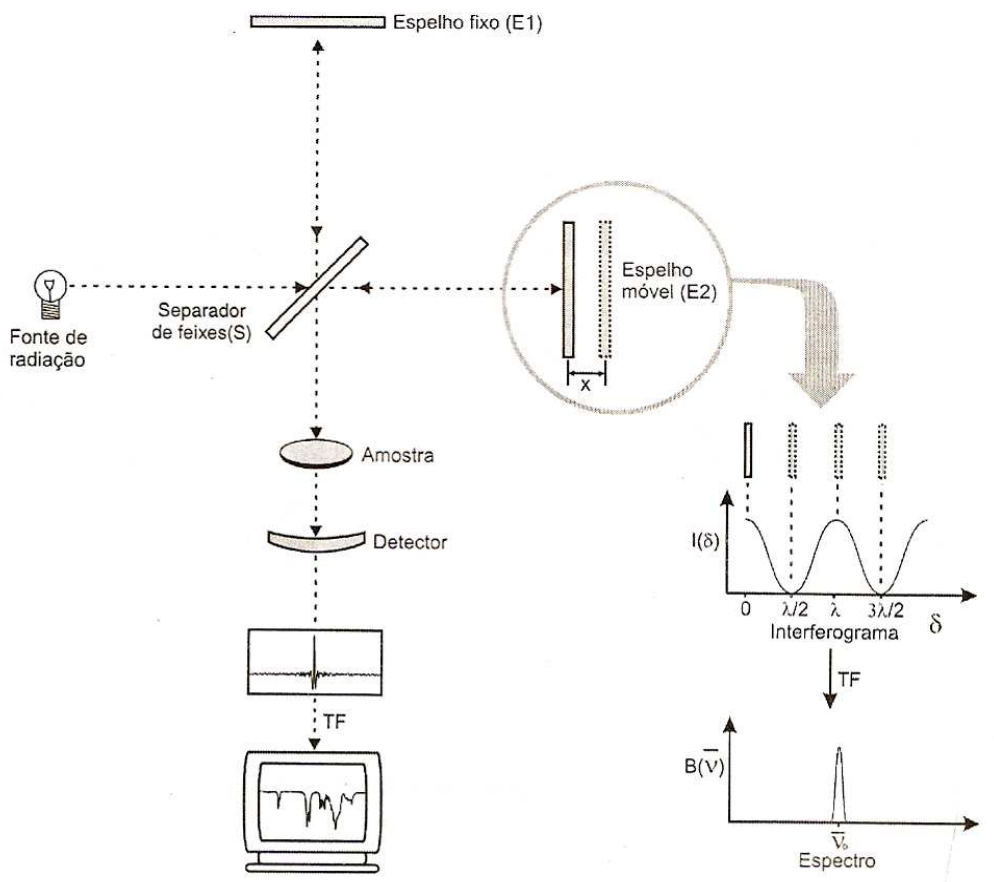

Figura 6 Esquema do interferômetro de Michelson utilizado na espectroscopia no infravermelho com transformada de Fourier. Fonte: Barbosa, 2007.

Graças a esses avanços tecnológicos, a espectroscopia no infravermelho, em sinergia com técnicas quimiométricas, fornece hoje um meio efetivo de fazer análises de misturas complexas sem a necessidade de qualquer separação prévia de seus componentes (BLANCO et al., 1995).

Outro problema contornado pelo desenvolvimento de cálculos matemáticos mais complexos foi a impossibilidade de analisar quantitativamente amostras sólidas de produtos agrícolas com o mínimo de preparação, sem a diluição em brometo de potássio (KBr), devido às distorções causadas pela absorção mais forte na região do infravermelho médio (REEVES III, 2003). Embora tais distorções ocorram no espectro de DRIFTS de produtos agrícolas e inclusive de solos (REEVES III, 2003), por meio do uso de métodos de calibração multivariada como a regressão por mínimos quadrados parciais, é possível superar os 
problemas causados por elas (WILLIAMS; NORRIS, 2001; BEEBE et al., 1998; NAES et al., 2002; MADARI et al., 2006b).

O uso dessas técnicas espectroscópicas, principalmente a NIRS, para a análise de fibras e proteínas em forragens e grãos tem sido estudado há décadas, entretanto o interesse em aplicá-las para estudos quantitativos de características e propriedades dos solos é relativamente recente (desde 1995) (MITTELMANN et al., 2005; MADARI et al., 2006b).

A precisão da espectroscopia por refletância no infravermelho próximo (NIRS) na predição do conteúdo de carbono já é conhecida (BEN-DOR; BANIN, 1995). Por outro lado, a espectroscopia no infravermelho por refletância difusa em infravermelho médio (DRIFTS) tem sido aplicada extensivamente em pesquisas de vários materiais incluindo matéria orgânica e substâncias húmicas (MARTIN-NETO et al., 2004; NIEMEYER et al., 1992). Os espectros são influenciados não só pelas propriedades químicas do material analisado, mas também pelo tamanho e arranjo das partículas. Enquanto NIRS utiliza radiação eletromagnética de 10000 a $4000 \mathrm{~cm}^{-1}(1000-2500 \mathrm{~nm})$, DRIFTS utiliza faixa de 4000 a $400 \mathrm{~cm}^{-1}(2500-25000 \mathrm{~nm})$.

Calibrações para carbono total e orgânico foram desenvolvidas por Madari et al. (2005) usando espectros de solos de diferentes texturas, ou seja, diferentes teores de argila, silte e areia, obtidos com DRIFTS e NIRS. Os espectros em DRIFTS foram menos influenciados pela granulometria das amostras, enquanto que o uso de espectros obtidos com NIRS resultou em ótimas calibrações somente no caso de populações muito homogêneas de amostras, em termos de distribuição de tamanho de partículas dentro de cada amostra.

A região do infravermelho médio já foi mais extensamente estudada quanto à absorção de compostos orgânicos, sendo possível identificar em tais espectros bandas referentes à absorção de diversos grupos funcionais de compostos orgânicos: ácidos carboxílicos, amidas, alquilas e aromáticos (VISCARRA-ROSSEL, 2006). Bandas intensas 
podem ser observadas em $3400 \mathrm{~cm}^{-1}$ (hidroxilas), $1630 \mathrm{~cm}^{-1}$ (carboxilatos e aromáticos), 2920 $\mathrm{cm}^{-1}$ (alifáticos) e $1450 \mathrm{~cm}^{-1}$ (amidas secundárias) (GERZABEK et al., 2006).

Os espectros de matéria orgânica do solo, assim como os espectros de bactérias (Figuras $7 \mathrm{e} \mathrm{8),} \mathrm{apresentam} \mathrm{sinais} \mathrm{em} \mathrm{torno} \mathrm{de} 3400 \mathrm{~cm}^{-1}, 2900 \mathrm{~cm}^{-1}, 1700 \mathrm{~cm}^{-1}, 1500 \mathrm{~cm}^{-1}$, $1300 \mathrm{~cm}^{-1}, 1100 \mathrm{~cm}^{-1}$. Na análise de células intactas, Filip e Hermann (2001) destacaram também as bandas em 1200-900 $\mathrm{cm}^{-1}$, onde há bastante sobreposição, mas é a faixa mais sensível e seletiva, e em 900-600 cm-1, onde há sinais de vibrações aromáticas de aminoácidos e nucleotídeos, chamada de região de impressão digital bacteriana.

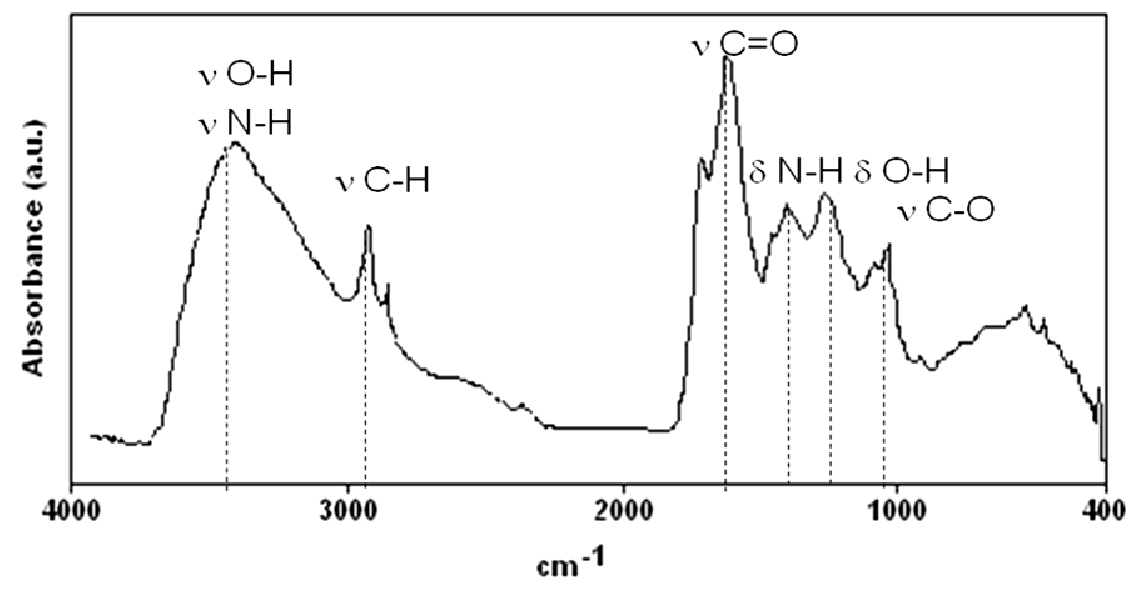

Figura 7 Espectro no infravermelho médio de matéria orgânica do solo. Fonte: Wilson Tadeu Lopes da Silva, Embrapa Instrumentação Agropecuária, 2008.

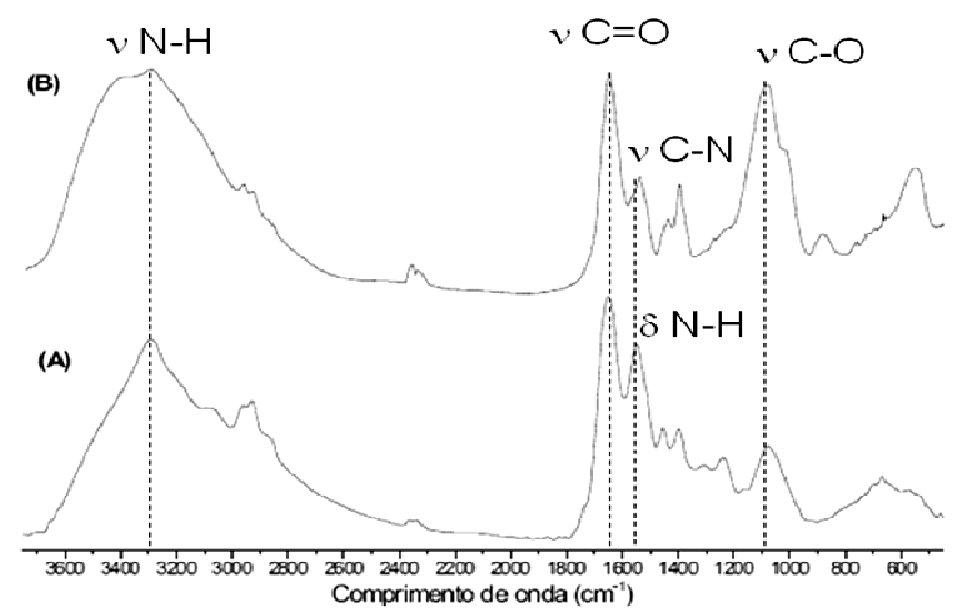

Figura 8 Espectros no infravermelho médio de Xylella depositada em janela silício (A) após 30 dias e (B) após 70 dias de crescimento. Fonte: Osiro et al., 2000. 
Ainda na análise de células bacterianas, Naumann et al. (1996) procuraram interpretar seus espectros tendo em mente as moléculas comumente encontradas nas paredes celulares, conforme colocado na Tabela 1.

Tabela 1 Tentativa de atribuição de bandas comumente encontradas em espectros de bactérias no infravermelho médio. Adaptada de: Naumann, 1996.

\begin{tabular}{|c|c|c|}
\hline Frequência $\left(\mathrm{cm}^{-1}\right)$ & Intensidade & Atribuição \\
\hline$\sim 3500$ & $\mathrm{M}$ & vO-H \\
\hline$\sim 3200$ & $\mathrm{~m}-\mathrm{F}$ & vN-H (amida A) de proteínas \\
\hline 2959 & $\mathrm{~F}$ & $v_{\mathrm{a}} \mathrm{C}-\mathrm{H}$ de metila \\
\hline 2934 & Mf & $v_{\mathrm{a}} \mathrm{C}-\mathrm{H}$ de metileno \\
\hline 2921 & M & $v_{\mathrm{a}} \mathrm{C}-\mathrm{H}$ de metileno de ácidos graxos \\
\hline 2898 & Mf & $v_{\mathrm{a}} \mathrm{C}-\mathrm{H}$ de metino \\
\hline 2872 & $\mathrm{~F}$ & $v_{s} \mathrm{C}-\mathrm{H}$ de metila \\
\hline 2852 & M & $v_{\mathrm{s}} \mathrm{C}-\mathrm{H}$ de metileno de ácidos graxos \\
\hline 1741 & $\mathrm{~F}$ & $v \mathrm{C}=\mathrm{O}$ de ésteres \\
\hline 1715 & Mf & $v \mathrm{C}=\mathrm{O}$ de ésteres, ácidos carbônicos \\
\hline 1695 & $\mathrm{~F}$ & Diferentes componentes \\
\hline 1685 & $\mathrm{~F}$ & da banda de amida I resultantes \\
\hline 1675 & $\mathrm{~F}$ & das folhas $\beta$-pregueadas de proteínas \\
\hline$\sim 1655$ & $\mathrm{~F}$ & Amida I das estruturas $\alpha$-hélices \\
\hline$\sim 1637$ & $\mathrm{~F}$ & Amida I das estruturas $\beta$-pregueadas \\
\hline 1548 & $\mathrm{~F}$ & Banda de amida II \\
\hline 1515 & M & Banda de vibração do anel de tirosina \\
\hline 1498 & $\mathrm{~F}$ & Banda de vibração do anel de fenilalanina \\
\hline 1468 & $f-m$ & $\delta \mathrm{C}-\mathrm{H}$ de metileno \\
\hline$\sim 1400$ & M & $v_{\mathrm{s}} \mathrm{COO}^{-}$ \\
\hline $1310-1240$ & $\mathrm{~F}$ & Componentes da banda de amida III de proteínas \\
\hline $1250-1220$ & $\mathrm{f}-\mathrm{m}$ & $v_{\mathrm{a}} \mathrm{PO}_{2}^{-}$de fosfodiesteres \\
\hline 1084-1088 & $\mathrm{f}-\mathrm{m}$ & $v_{s} \mathrm{PO}_{2}^{-}$de fosfodiesteres \\
\hline $1200-900$ & M & Vibrações de anéis de polissacarídeos com $\mathrm{C}-\mathrm{O}-\mathrm{C}, \mathrm{C}-\mathrm{O}, \mathrm{C}-\mathrm{O}-\mathrm{P}, \mathrm{P}-\mathrm{O}-\mathrm{P}$ \\
\hline 720 & Mf & $\rho \mathrm{C}-\mathrm{H}$ de metileno \\
\hline $900-600$ & F & Região de fingerprint \\
\hline
\end{tabular}


Ben-Dor e Banin (1995) constataram que a matéria orgânica também é espectroscopicamente ativa em toda a região do infravermelho próximo. O espectro de NIR (Figura 9) é constituído de bandas fracas de acoplamentos e combinações das bandas de vibração de C-H, N-H e O-H que ocorrem na região do infravermelho médio (GERZABEK et al., 2006), sendo, por esse motivo, não muito seletivo e pouco utilizado para a interpretação e elucidação de estruturas moleculares (WESTAD et al., 2008).

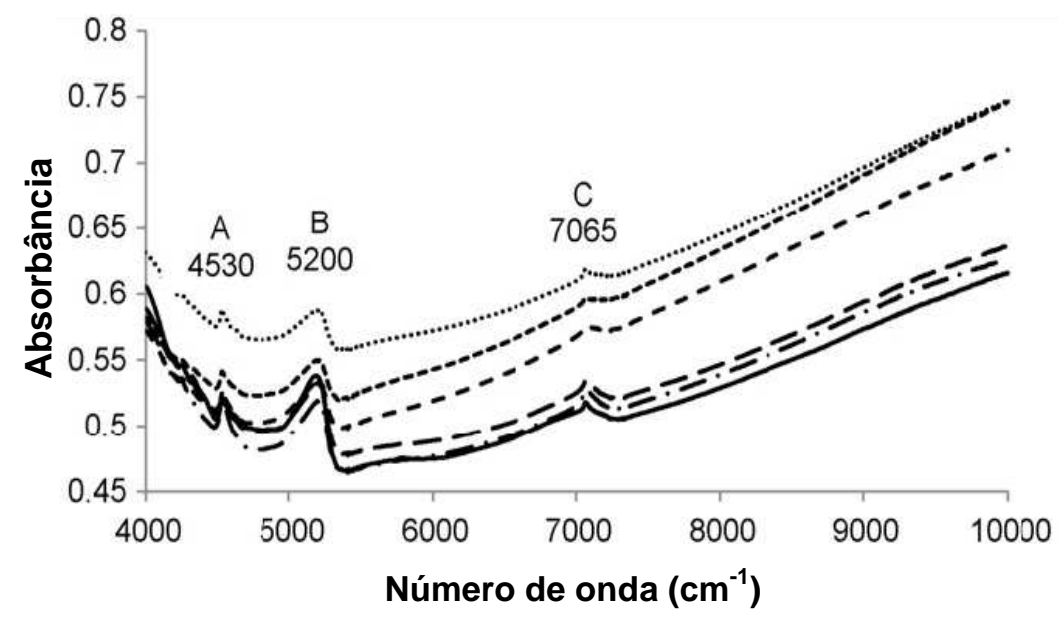

Figura 9 Espectro de NIRS de solos afetados por diferentes ocorrências de fogo. Traduzida de: Vergnoux et al., 2009.

Aparentemente, o espectro no infravermelho médio é mais informativo que aquele obtido por NIRS. Entretanto, deve-se destacar que os componentes inorgânicos como a sílica, que são predominantes no solo e dificultam a identificação de bandas características de compostos orgânicos do solo, não absorvem na região do infravermelho próximo, mas sim no infravermelho médio (MADARI et al., 2005).

Outras vantagens da NIRS incluem alta razão sinal-ruído (tipicamente 25000:1), alta passagem energética pelos cabos de fibra óptica e disponibilidade de caminhos ópticos de diversos tamanhos (WORKMAN, 1998).

Algumas atribuições de bandas em NIRS são apresentadas na Tabela 2. Dentre os comprimentos de onda selecionados por Palmborg e Nordgren (1993), na região do infravermelho próximo, para correlacionar com respiração microbiana, foram identificadas 
absorções em 7022, 6631, 6561 e $5030 \mathrm{~cm}^{-1}$ relacionados a grupos $\mathrm{OH}$, em 6631, 6561, 5030 e $5000 \mathrm{~cm}^{-1}$ referentes a aminas e amidas e em 5319 e $5274 \mathrm{~cm}^{-1}$ devido a fosfatos orgânicos. Essas bandas estão muito correlacionadas, em ciência dos alimentos, com proteína e amido, o que conduz à ideia de que a disponibilidade de $\mathrm{N}$ e carboidrato têm um papel fundamental na atividade da biomassa microbiana do solo.

Tabela 2 Bandas de absorção das vibrações de estiramento dos principais grupos funcionais no espectro no infravermelho próximo $\left(\mathrm{cm}^{-1}\right)$. Adaptada de: Workman, 1998.

\begin{tabular}{|c|c|c|c|c|}
\hline Estrutura & Ligação & $1^{\text {a }}$ harmônica & $2^{\mathrm{a}}$ harmônica & $3^{\text {a }}$ harmônica \\
\hline ArCH (aromáticos) & $\mathrm{C}-\mathrm{H}$ & $8748-8424$ & $8748-8424$ & $11668-11235$ \\
\hline $\mathrm{CH}=\mathrm{CH}$ (metileno) & $\mathrm{C}-\mathrm{H}$ & $8064-8019$ & $8064-8019$ & $10752-10695$ \\
\hline $\mathrm{CH}_{3}$ (metil) & $\mathrm{C}-\mathrm{H}$ & $8223-8196$ & $8223-8196$ & 10964-10928 \\
\hline $\mathrm{CH}_{3}$ (metil) & $\begin{array}{c}\text { C-H } \\
\text { combinação }\end{array}$ & $7423-7315$ & $7423-7315$ & $9900-9756$ \\
\hline R-OH (álcoois) & $\mathrm{O}-\mathrm{H}$ & $7092-6872$ & $10638-10309$ & $*$ \\
\hline ArOH (fenóis) & $\mathrm{O}-\mathrm{H}$ & $7037-6802$ & $10559-10204$ & $*$ \\
\hline $\mathrm{HOH}$ (água) & $\mathrm{O}-\mathrm{H}$ & $6944-6734$ & 10416.-10101 & * \\
\hline Amido & $\mathrm{O}-\mathrm{H}$ & 6891 & 10341 & * \\
\hline Uréia & $\mathrm{N}-\mathrm{H}$ & 6849 & 10277 & $*$ \\
\hline $\mathrm{CONH}_{2}$ (amidas primárias) & $\mathrm{N}-\mathrm{H}$ & $6835-6738$ & $10256-10111$ & $*$ \\
\hline CONHR (amidas secundárias) & $\mathrm{N}-\mathrm{H}$ & 6793 & 10193 & $*$ \\
\hline Celulose & $\mathrm{O}-\mathrm{H}$ & 6711 & 10070 & $*$ \\
\hline Uréia & $\mathrm{N}-\mathrm{H}$ & 6711 & 10070 & * \\
\hline $\mathrm{ArNH}_{2}$ (aminas aromáticas) & $\mathrm{N}-\mathrm{H}$ & 6697 & 10050 & $*$ \\
\hline NH (aminas em geral) & $\mathrm{N}-\mathrm{H}$ & 6666 & 10000 & $*$ \\
\hline Proteínas & $\mathrm{N}-\mathrm{H}$ & 6618 & 9930 & $*$ \\
\hline Uréia & $\mathrm{N}-\mathrm{H}$ & 6578 & 9871 & $*$ \\
\hline $\mathrm{RNH}_{2}$ (aminas primárias) & $\begin{array}{c}\text { N-H } \\
\text { combinação }\end{array}$ & $*$ & 9803 & $*$ \\
\hline Amido & $\begin{array}{c}\text { O-H } \\
\text { combinação }\end{array}$ & $*$ & 9737 & $*$ \\
\hline $\mathrm{CONH}$ (amidas primárias) & $\begin{array}{c}\mathrm{N}-\mathrm{H} \\
\text { combinação }\end{array}$ & $*$ & 9551 & $*$ \\
\hline$=\mathrm{CH} 2$ (metileno) & $\begin{array}{c}\mathrm{C}-\mathrm{H} \\
\text { combinação }\end{array}$ & * & 9259 & $*$ \\
\hline
\end{tabular}




\subsection{Análise Multivariada}

Uma das chaves para a análise quantitativa em qualquer campo da ciência é suposição de que os constituintes de interesse em uma amostra estão relacionados com os dados obtidos por determinada técnica de análise, principalmente as espectroscópicas. Para saber qual é essa relação, cria-se uma equação de calibração a partir de amostras-padrão, que é conhecida também como modelo (DUCKWORTH, 1998).

O modelo estatístico dos métodos multivariados considera a correlação entre muitas variáveis analisadas simultaneamente, permitindo a extração de uma quantidade muito maior de informação comparada à análise univariada (SENA et al., 2000). Tem como princípio a utilização de muitas variáveis $\mathrm{x}\left(\mathrm{x}_{1}, \mathrm{x}_{2}, \ldots, \mathrm{x}_{\mathrm{n}}\right)$ para quantificar outra variável y (OLENDZKI, 2006). Dessa forma, o uso do espectro de uma amostra, o qual contém muitos dados, traz algumas vantagens em relação à leitura em somente um comprimento de onda, pois, quanto mais medidas por amostra, mais acurados podem ser os resultados (DUCKWORTH, 1998).

Segundo Mark e Workman (2003), uma equação de regressão com vários comprimentos de onda, derivada da Lei de Beer-Lambert, poderia ser expressa como (Equação 7):

onde:

$$
\mathrm{Y}=\mathrm{B}_{0}+\mathrm{B}_{\mathrm{i}} \mathrm{x} \log \left(1 / \mathrm{R}_{\mathrm{i}}\right)[+\mathrm{E}] \text { (Equação 7) }
$$

$\mathrm{Y}=$ porcentagem de concentração da substância absorvedora

$\mathrm{B}_{0}=$ intercepto da regressão

$\mathrm{B}_{\mathrm{i}}=$ coeficiente de regressão

$\mathrm{i}$ = índice do comprimento de onda usado e sua correspondente refletância $\left(\mathrm{R}_{\mathrm{i}}\right)$

$\mathrm{E}=$ erro aleatório

Esta relação entre concentração e dados ópticos pode ser traduzida para (Equação 8):

Conc $=($ Mudança na concentração/ Mudança na Absorbância $) \times$ Absorbância + Erro ou 


$$
\text { Conc }=\text { B x Absorbância }+ \text { Erro (Equação 8) }
$$

Assim, se houver uma grande mudança na concentração e também na absorbância, significa que o coeficiente de regressão (B) será pequeno, indicando uma alta sensibilidade e uma boa razão sinal-ruído. Entretanto, se a variação for grande na concentração e pequena na absorbância, o coeficiente será maior, indicando uma baixa sensibilidade do modelo (MARK; WORKMAN, 2003).

Em amostras reais, existem diferentes variações refletidas nos espectros: os constituintes da amostra, a interação entre esses constituintes, as variações do instrumento como ruído do detector, alterações nas condições ambientais (que afetam a linha de base) e diferenças na manipulação das amostras. As variações dos espectros são frequentemente chamadas de autovetores, loadings espectrais, componentes principais ou fatores, enquanto as constantes usadas para reconstruir os espectros são conhecidas como scores (DUCKWORTH, 1998).

Vários modelos têm sido usados para medir propriedades de materiais por espectros em infravermelho. Os mais utilizados são: regressão de componentes principais (PCR), regressão dos mínimos quadrados parciais (PLS), regressão de Fourier e redes neurais artificiais (CHANG et al., 2001).

A PLS é uma combinação da análise de componentes principais e regressão múltipla e é considerada uma das mais robustas para dados multidimensionais, incluindo toda a informação disponível nos espectros (SHENK; WESTERHAUSS, 1994).

A PCR e PLS são duas técnicas de decomposição espectral; porém, enquanto a PCR decompõe a matriz espectral em uma série de loadings e scores e, em seguida, como uma etapa separada, faz a regressão deles contra as concentrações dos componentes da amostra, a PLS usa a informação da propriedade que está sendo modelada durante o processo de decomposição. Isso faz com que os espectros de amostras com maiores concentrações tenham 
maior peso. A principal ideia da PLS é obter o máximo de informação nos primeiros vetores de loadings (DUCKWORTH, 1998).

A regressão fornece o modelo linear que melhor descreve a correlação entre absorbância e concentração, minimizando a soma dos quadrados dos resíduos (distâncias) de cada ponto da linha. Apesar da Lei de Beer-Lambert se aplicar apenas à espectroscopia de transmissão, na falta de um modelo matemático ideal para a espectroscopia de refletância, ela é utilizada nessas calibrações após transformar os dados de refletância em absorbância (MARK; WORKMAN, 2003).

O pré-tratamento dos espectros com o cálculo de derivadas é usado geralmente para excluir o efeito do intercepto diferente de zero. No entanto, as derivadas não removem o erro multiplicativo e as não-linearidades. Essas interferências são reduzidas pelo uso do background (MARK; WORKMAN, 2003).

Os resíduos entre valores preditos pelo modelo obtido por PLS e os valores de referência fornecem subsídios para a avaliação da qualidade da calibração. Para isso, faz-se a predição para um grupo de amostras de validação, que pode conter as mesmas amostras de calibração, realizando-se a validação cruzada, ou pode ser constituída de amostras não contidas no grupo de calibração, mas com valores conhecidos para cada propriedade, procedendo à validação externa. Os resíduos resultantes dessas predições são chamados neste trabalho de SEV e Erro\%, respectivamente, e os coeficientes de regressão entre os valores medidos e preditos são denominados RVC e RVE. O cálculo desses parâmetros é descrito nas equações 9 e 10 .

$\mathrm{SEV}=\left[\sum_{\mathrm{i}=1}^{\mathrm{n}} \sum_{\mathrm{j}=1}^{\mathrm{m}}\left(\mathrm{y}_{\mathrm{i}, \mathrm{j}}-\hat{\mathrm{y}}_{\mathrm{i}, \mathrm{j}}\right)^{2}\right]^{1 / 2} \mathrm{x} \mathrm{n}^{-1}$ (Equação 9) $\quad$ Erro\% $=|\mathrm{y}-\hat{\mathrm{y}}| \times \mathrm{y}^{-1} \times 100 \quad$ (Equação 10) onde:

$\mathrm{y}=$ valor medido

$\hat{\mathrm{y}}=$ valor predito

$\mathrm{n}=$ número de valores de referência $\mathrm{m}=$ número de valores preditos

$\mathrm{i}=$ índice de valores de referência

$\mathrm{j}$ = índice de valores preditos 


\section{OBJETIVOS}

O objetivo geral desse trabalho foi estudar o potencial da espectroscopia de refletância no infravermelho próximo e médio na quantificação de algumas propriedades do solo. Para atingir este objetivo, algumas metas foram traçadas:

a) Determinar alguns parâmetros do solo, adotando como métodos de referência aqueles mais utilizados no estudo de solos;

b) Obter espectros das amostras, secas e trituradas, pela técnica de refletância difusa nas regiões do infravermelho próximo e médio;

c) Visualizar a distribuição dos solos e detectar semelhanças e agrupamentos, utilizando a análise de componentes principais (PCA) a partir dos dados de quantificação, das informações disponíveis sobre esses solos e dos espectros.

d) Correlacionar com os espectros as medidas de $\mathrm{pH}$, textura, carbono total, orgânico e microbiano, respiração basal do solo, nitrogênio total e microbiano, coeficientes metabólico e microbiano e razões $\mathrm{C} / \mathrm{N}$ do solo e microbiano, através de calibração multivariada (Parcial Least Squares - PLS);

e) Verificar se a espectroscopia de refletância difusa no infravermelho é adequada para a quantificação dessas propriedades do solo e analisar as vantagens e as possibilidades de melhoria no intuito de atingir uma precisão aceitável em termos agronômicos;

f) Avaliar as duas regiões do infravermelho quanto à capacidade de predição. 


\section{MATERIAIS E MÉTODOS}

\subsection{Coleta de solo}

Foram coletadas amostras superficiais $(0-10 \mathrm{~cm})$ em fazendas experimentais pertencentes à Embrapa Arroz e Feijão (ou CNPAF - Centro Nacional de Pesquisa em Arroz e Feijão) e à Embrapa Pecuária Sudeste (ou CPPSE - Centro Nacional de Pesquisa em Pecuária Sudeste), localizadas em Santo Antônio de Goiás-GO e em São Carlos-SP, respectivamente.

Em Santo Antônio de Goiás, foram obtidas amostras de solo de diferentes experimentos com cultivo de arroz, feijão, café, banana e pastagens em sistemas de integração lavoura-pecuária, agricultura orgânica e irrigação por pivô central, acrescentadas de amostras de matas com vegetação nativa de Cerrado. As amostras numeradas de 1 a 40 são provenientes de um experimento com agricultura orgânica, constituído de 40 parcelas de 100 $\mathrm{m}^{2}$ divididas por sistema de plantio e plantas de coberturas de inverno, conforme Figura 10 e destaque em amarelo na Figura 11. A coleta foi realizada em fevereiro de 2009, após o plantio de arroz e feijão sobre as coberturas de inverno. Nessa mesma época, foram obtidas três amostras de uma área com vegetação nativa próxima ao experimento (amostras AF41 a AF43). O restante das amostras coletadas na Embrapa Arroz e Feijão foi obtido no período de outubro a novembro de 2009, resultando em um total de 114 amostras nesse local. A região de Goiás, portanto, foi amostrada em duas épocas do período chuvoso.

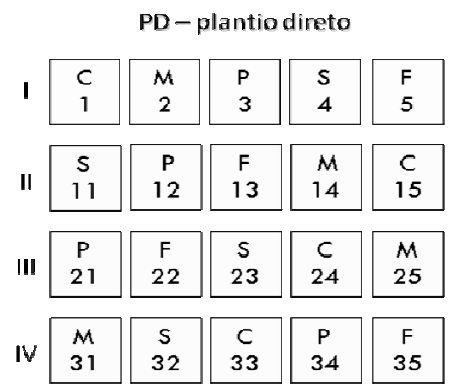

\begin{tabular}{|c|c|c|c|c|}
\hline $\begin{array}{l}c \\
6\end{array}$ & $\begin{array}{l}\mathrm{P} \\
7\end{array}$ & $\begin{array}{c}M \\
8\end{array}$ & $\begin{array}{l}5 \\
9\end{array}$ & $\begin{array}{c}F \\
10\end{array}$ \\
\hline $\begin{array}{l}M \\
16\end{array}$ & $\begin{array}{c}5 \\
17\end{array}$ & $\begin{array}{c}F \\
18\end{array}$ & $\begin{array}{c}\mathbf{P} \\
19\end{array}$ & $\underset{20}{C}$ \\
\hline $\begin{array}{c}5 \\
26\end{array}$ & $\begin{array}{c}F \\
27\end{array}$ & $\begin{array}{c}P \\
28\end{array}$ & $\begin{array}{l}M \\
29\end{array}$ & $\begin{array}{c}C \\
30\end{array}$ \\
\hline $\begin{array}{c}C \\
36\end{array}$ & $\begin{array}{c}S \\
37\end{array}$ & $\begin{array}{l}M \\
38\end{array}$ & $\begin{array}{c}F \\
39\end{array}$ & $\begin{array}{c}P \\
40\end{array}$ \\
\hline
\end{tabular}

Figura 10 Croqui da área experimental da Fazenda Agroecológica da Embrapa Arroz e Feijão, Santo Antônio de Goiás. Parcelas de 10x10m. Áreas com plantio direto - PD e plantio convencional - PC. Coberturas de inverno em quatro repetições de campo: $\mathrm{C}$ - crotalária; $\mathrm{M}$ - mucuna; $\mathrm{P}$ - pousio; $\mathrm{S}$ - sorgo; $\mathrm{F}$ - feijão-de-porco. 


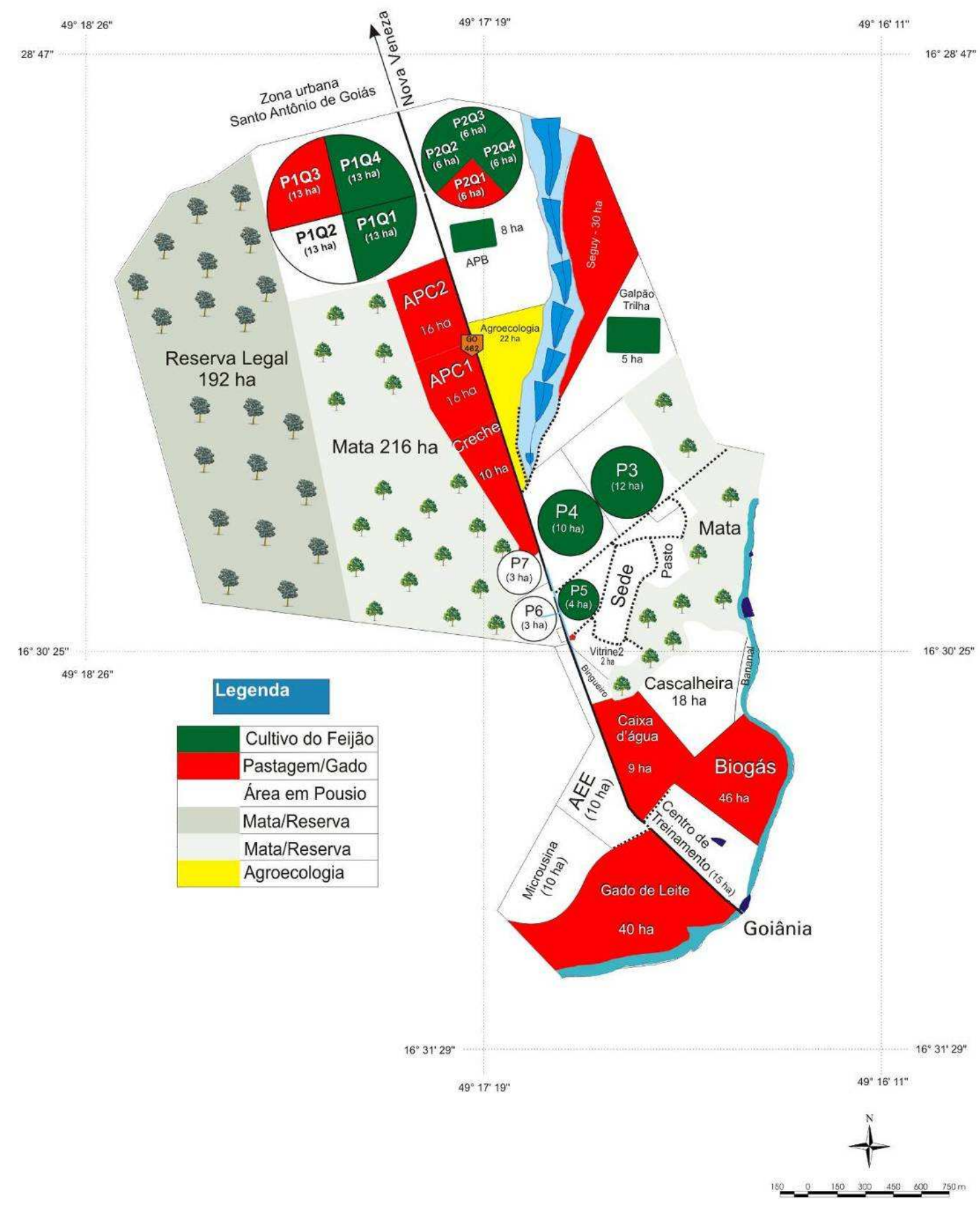

Figura 11 Mapa da fazenda experimental Capivara da Embrapa Arroz e Feijão, em Santo Antônio de Goiás. Fonte: figura cedida por Beáta Emöke Madari.

Na Embrapa Pecuária Sudeste, em São Carlos (Figura 12), fez-se uma amostragem de diversos experimentos, incluindo pastagens, algumas culturas como cana, alfafa e aveia, além de áreas com vegetação nativa de Cerrado em duas fases de amadurecimento, somando 57 amostras deste local e totalizando 171 amostras coletadas. O período de amostragem nessa região se estendeu de maio a agosto de 2009 , onde houve maior variação de temperatura e 
umidade que em Santo Antônio de Goiás.

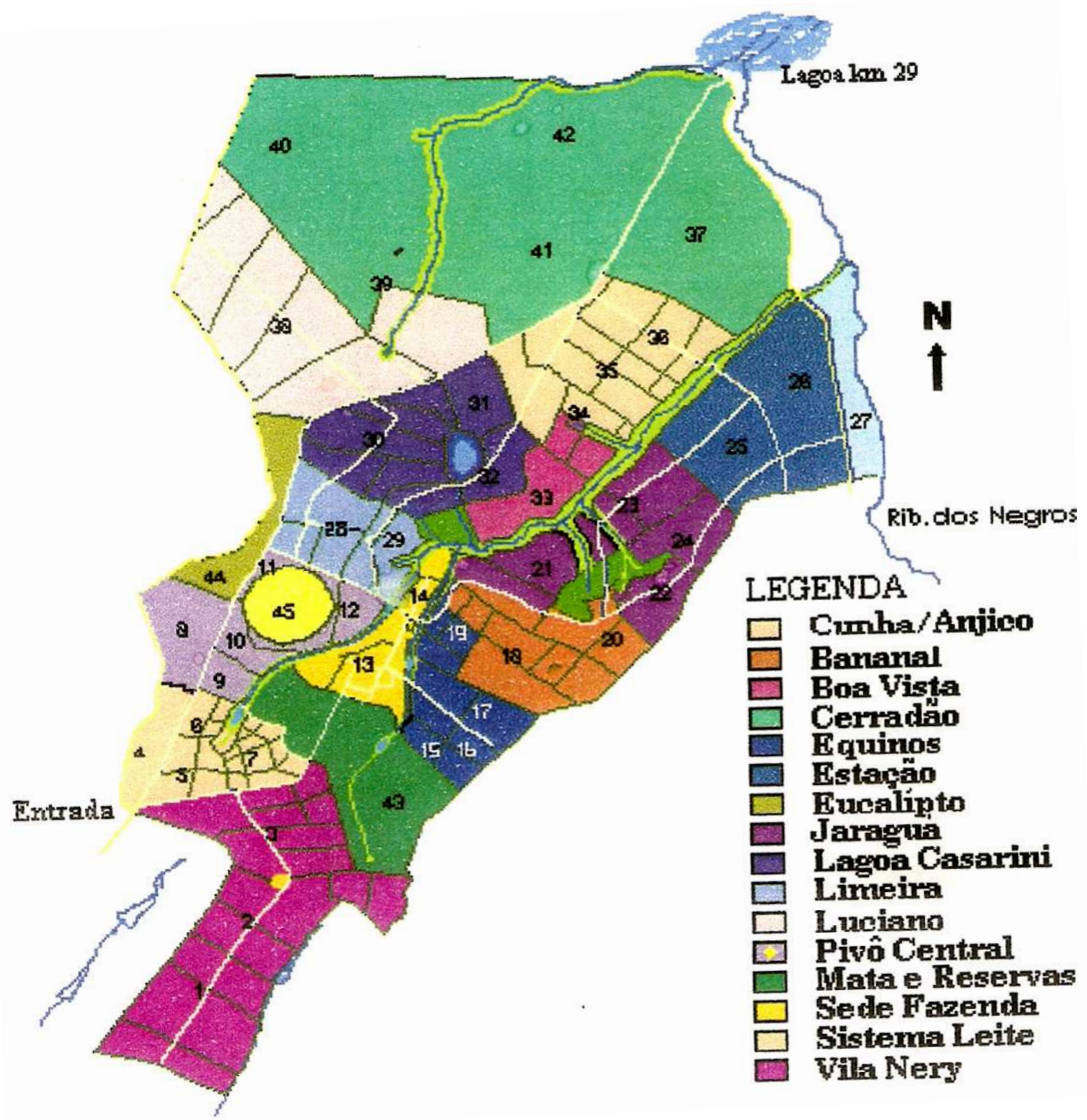

Figura 12 Mapa da fazenda experimental Canchim da Embrapa Pecuária Sudeste, em São Carlos-SP. Os números da figura não estão relacionados com os números das amostras coletadas. Fonte: Primavesi et al., 1999.

A coleta foi realizada com auxílio de um trado holandês, na profundidade $0-10 \mathrm{~cm}$, sendo cada amostra composta de cinco pontos escolhidos ao acaso. Também foram coletadas amostras indeformadas em cilindros de Kopecky, encaminhadas, logo em seguida, ao laboratório de solos da Embrapa Arroz e Feijão para a obtenção da curva de retenção e determinação da capacidade de campo (EMBRAPA SOLOS, 1997). Para as demais análises, o solo foi armazenado em geladeira. 


\subsection{Determinação da capacidade de campo}

Os dados de capacidade de campo são originários da curva de retenção de água no solo e são utilizados para uniformizar a umidade dos solos na determinação da biomassa microbiana. Amostras de solo indeformadas, coletadas em cilindros de Kopecky, foram colocadas em bandejas com água durante 24 horas para saturação total. Após esse período, os cilindros foram submetidos à pressão de $60 \mathrm{KPa}$, equivalente a 1800 rpm em centrífuga, determinandose em seguida a umidade restante, relativa à capacidade de campo do solo (EMBRAPA SOLOS, 1997).

\subsection{Determinação da umidade do solo}

Alíquotas de $10-15 \mathrm{~g}$ de solo foram acondicionadas em latas de alumínio de $15 \mathrm{~cm}$ de diâmetro ou vidros-relógio com 20-30 cm de diâmetro e colocadas em estufa a $105^{\circ} \mathrm{C}$ por 24 horas. Após esse período, os recipientes com solo seco e vazios foram pesadas em balança de precisão e o cálculo da umidade seguiu a seguinte fórmula, expressa pela Equação 11:

onde:

$$
\mathrm{U}=100 \times\left(\mathrm{P}_{\mathrm{U}}-\mathrm{P}_{\mathrm{S}}\right) /\left(\mathrm{P}_{\mathrm{U}}-\mathrm{P}_{\mathrm{R}}\right)(\text { Equação 11) }
$$

$$
\begin{aligned}
& \mathrm{U}=\text { umidade do solo }(\%) \\
& \mathrm{P}_{\mathrm{U}}=\text { peso do solo úmido com o recipiente } \\
& \mathrm{P}_{\mathrm{S}}=\text { peso do solo seco com o recipiente } \\
& \mathrm{P}_{\mathrm{R}}=\text { peso do recipiente (lata ou vidro relógio) }
\end{aligned}
$$

\subsection{Determinação do $\mathrm{pH}$}

$\mathrm{O} \mathrm{pH}$ foi determinado segundo metodologia Embrapa Solos (1997). Misturas de 10g de solo seco, moído e passado em peneira de $2 \mathrm{~mm}$, com $25 \mathrm{~mL}$ de água destilada foram homogeneizados manualmente com bastão de vidro. Após uma hora de descanso, foi separado o sobrenadante e com este realizada a leitura em pHmetro da marca Thermo Scientific. 


\subsection{Método de referência para textura do solo}

O método do densímetro foi utilizado para determinar a textura (ou granulometria) do solo. Conforme descrito no manual da Embrapa Solos (1997), alíquotas de 50 g de solo seco e moído (2 mm) foram saturados com hidróxido de sódio $(\mathrm{NaOH}) 1 \mathrm{~mol} \mathrm{~L}^{-1}$, hexametafosfato de sódio, peróxido de hidrogênio e água destilada. Esperou-se um tempo de 30 minutos em repouso para a desagregação química do solo, agitando-se, em seguida, por 10 minutos em agitador elétrico tipo strirrer para a desagregação total.

O conteúdo do copo do agitador foi transferido para uma proveta de $1000 \mathrm{~mL}$ completando-se o volume, com o densímetro em solução, para $1000 \mathrm{~mL}$ com água. Retirado o densímetro, agitou-se manualmente o conteúdo da proveta por 30 segundos seguidos de repouso de 40 segundos. A leitura da densidade foi realizada após este repouso como referência da fração areia decantada, sendo repetida após nova agitação manual de 30 segundos e repouso de 2 horas para o cálculo da fração argila, sempre se anotando a temperatura juntamente com a densidade para as devidas correções. A fração silte foi calculada a partir dos valores de areia e argila. Os cálculos foram realizados conforme as Equações 12 a 14.

$$
\begin{gathered}
\mathrm{A}_{\mathrm{g}}\left(\mathrm{g} \mathrm{Kg}^{-1}\right)=\left[\left(\mathrm{D}_{2} \times 100\right) / 50\right] \times 10 \text { (Equação 12) } \\
\mathrm{A}_{\mathrm{e}}\left(\mathrm{g} \mathrm{Kg}^{-1}\right)=\left\{100-\left[\mathrm{D}_{1} \times 100\right] / 50\right\} \times 10 \text { (Equação 13) } \\
\mathrm{S}\left(\mathrm{g} \mathrm{Kg}^{-1}\right)=\left\{\left[\left(\mathrm{D}_{1}-\mathrm{D}_{2}\right) \times 100\right] / 50\right\} \times 10 \text { (Equação 14) }
\end{gathered}
$$

onde:

$$
\begin{aligned}
& A_{g}=g \text { argila } \mathrm{Kg}^{-1} \text { solo } \\
& A_{e}=g \text { areia } \mathrm{Kg}^{-1} \text { solo } \\
& \mathrm{S}=\mathrm{g} \text { silte } \mathrm{Kg}^{-1} \text { solo } \\
& \mathrm{D}_{1}=\text { primeira leitura da densidade corrigida para a temperatura ambiente } \\
& \mathrm{D}_{2}=\text { segunda leitura da densidade corrigida para a temperatura ambiente após } 2 \text { horas }
\end{aligned}
$$


De acordo com os teores de argila, silte e areia obtidos, os solos foram classificados quanto à textura conforme a Figura13 .

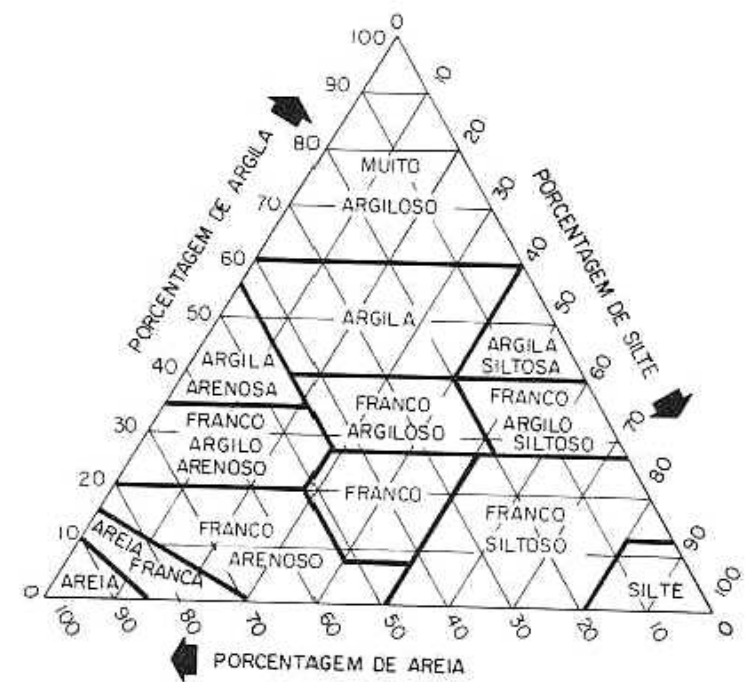

Figura 13 Diagrama triangular das classes texturais do solo. Fonte: Prevedello, 1996.

\subsection{Método de referência para carbono e nitrogênio totais (CT e NT)}

As amostras de solo, incubadas juntamente com aquelas destinadas à determinação da biomassa microbiana, foram secas ao ar livre e à sombra e depois trituradas em moinho de bolas, homogeneizadas e peneiradas $(0,250 \mathrm{~mm})$. Foram pesadas alíquotas de $8 \mathrm{mg}$ de solo e 2 mg de padrão sulfanilamida na microbalança Autobalance Controller AD6 Perkin Elmer e submetidas à combustão no analisador elementar CHNS/O Perkin-Elmer modelo 2400 Series II, pertencentes à Embrapa Arroz e Feijão.

\subsection{Método de referência para carbono orgânico total (COT)}

Utilizou-se o método da Embrapa Solos (1997) no qual 0,5 g de solo seco, moído e peneirado $(2 \mathrm{~mm})$ foi submetido à oxidação com $10 \mathrm{~mL}$ de dicromato de potássio $0,066 \mathrm{~mol}$ $\mathrm{L}^{-1}$ e $20 \mathrm{~mL}$ de ácido sulfúrico concentrado. Foi preparado também um branco com a adição de dicromato e ácido sulfúrico. Após homogeneização das amostras e do branco, a oxidação ocorreu durante 30 minutos em capela de exaustão sem aquecimento adicional. Em seguida, adicionaram-se $200 \mathrm{~mL}$ de água destilada e $10 \mathrm{~mL}$ de ácido fosfórico concentrado. A 
quantificação do dicromato em excesso foi realizada por titulação com sulfato ferroso 18,4 mol L $\mathrm{L}^{-1}$ e difenilamina como indicador, até coloração verde. O cálculo do carbono orgânico total foi realizado através da fórmula apresentada na Equação 15:

$$
\mathrm{COT}=\left(\left(\mathrm{V}_{\mathrm{B}}-\mathrm{V}_{\mathrm{A}}\right) / \mathrm{m}\right) \mathrm{x} \mathrm{f}(\text { Equação 15) }
$$

onde:

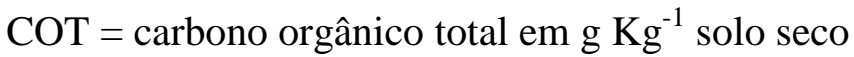

$\mathrm{V}_{\mathrm{B}}=$ volume de sulfato ferroso gasto na titulação do branco

$\mathrm{V}_{\mathrm{A}}=$ volume de sulfato ferroso gasto na titulação da amostra

$\mathrm{m}=$ massa de solo analisada $(0,5 \mathrm{~g})$

$\mathrm{f}=$ fator de correção do método $(0,39)$

\subsection{Método de referência para biomassa microbiana}

O método descrito por Vance et al. (1987a) foi escolhido como referência para biomassa microbiana por ser largamente usado em pesquisa agronômica.

As amostras de solo úmidas foram passadas em peneira de $4 \mathrm{~mm}$ e pesadas em 6 replicatas, sendo uma triplicata destinada à fumigação e outra triplicata de referência (amostras não-fumigadas). A umidade de todas as amostras foi corrigida para no mínimo 50\% da capacidade de campo adicionando-se água destilada.

Todas as amostras foram acondicionadas em frascos com tampa e incubadas em câmara escura à temperatura ambiente. Nos frascos contendo as amostras controles foram adicionados frascos menores contendo uma solução de hidróxido de potássio $0,3 \mathrm{~mol} \mathrm{~L}^{-1}$ para capturar o $\mathrm{CO}_{2}$ resultante da respiração basal do solo, conforme reação apresentada na Equação 16.

$$
\mathrm{CO}_{2}+2 \mathrm{KOH} \rightarrow \mathrm{K}_{2} \mathrm{CO}_{3}+\mathrm{H}_{2} \mathrm{O}+\mathrm{KOH}_{\text {exc }} \text { (Equação 16) }
$$

Após seis dias, as triplicatas a serem fumigadas foram transferidas, sem tampas, para um dessecador contendo uma placa de Petri aberta com clorofórmio, permanecendo sob vácuo 
e na ausência de luz durante 24 horas. No dia seguinte, o carbono e o nitrogênio orgânicos foram extraídos de todas as amostras utilizando-se uma solução de sulfato de potássio 0,5 mol $\mathrm{L}^{-1}$ pH 6,5-6,8 e 30 minutos de agitação orbital a 250 rpm (Figura 14).

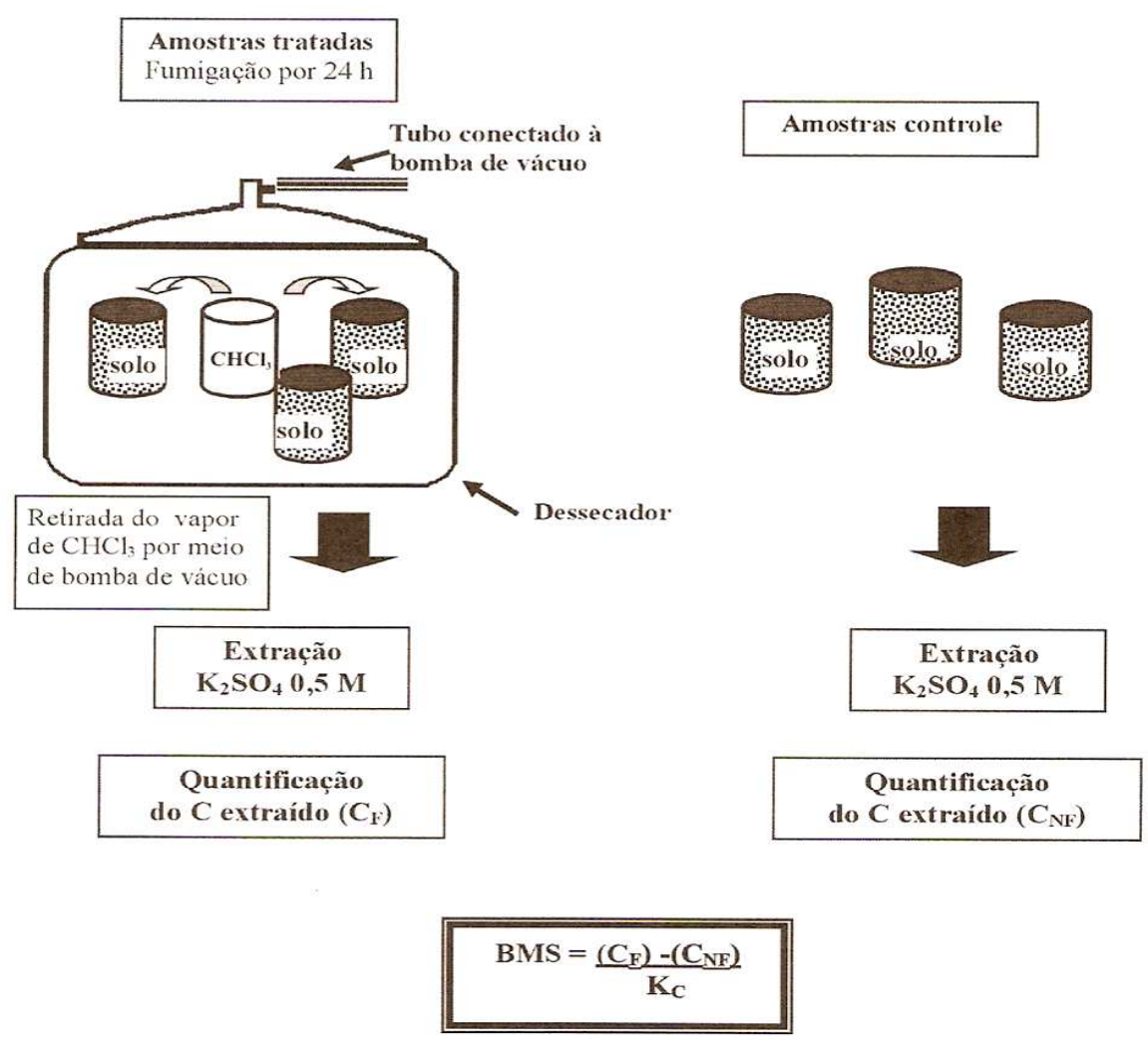

Figura 14 Quantificação da biomassa microbiana do solo pelo método de fumigação-extração (Vance et al., 1987). Fonte: Moreira e Siqueira, 2006.

No mesmo dia, determinou-se a respiração basal do solo pela titulação da solução de $\mathrm{KOH}$ restante no frasco incubado juntamente com as amostras controles. $\mathrm{O} \mathrm{KOH}$ excedente foi estabilizado com cloreto de bário $20 \%$ (Equação 17) e, em seguida, titulado com ácido clorídrico $0,1 \mathrm{~mol} \mathrm{~L}^{-1}$ e fenolftaleína como indicador (Equação 18).

$$
\begin{gathered}
\mathrm{K}_{2} \mathrm{CO}_{3}+\mathrm{BaCl}_{2} \rightarrow \mathrm{BaCO}_{3}(\mathrm{~s})+2 \mathrm{KCl}+\mathrm{KOH}_{\mathrm{exc}}(\text { Equação 17) } \\
\mathrm{KOH}_{\mathrm{exc}}+\mathrm{HCl} \rightarrow \mathrm{KCl}+\mathrm{H}_{2} \mathrm{O}(\text { Equação 18) }
\end{gathered}
$$

A respiração basal do solo foi calculada de acordo com a Equação 19. 


$$
R B=\left(V_{B}-V_{A}\right) \times C_{A C} \times N \times M_{C} \times P^{-1} \times \mathrm{f} \mathrm{d} \mathrm{d}^{-1} \times h^{-1} \text { (Equação 19) }
$$

onde:

$\mathrm{RB}=$ respiração basal do solo $\left(\mathrm{mg} \mathrm{C}-\mathrm{CO}_{2} \mathrm{Kg}^{-1}\right.$ solo seco hora $\left.{ }^{-1}\right)$

$\mathrm{V}_{\mathrm{B}}=$ média do volume de ácido clorídrico gasto na titulação da triplicata do branco $(\mathrm{mL})$

$\mathrm{V}_{\mathrm{A}}=$ média do volume de ácido clorídrico gasto na titulação da triplicata de amostras $(\mathrm{mL})$

$\mathrm{C}_{\mathrm{AC}}=$ concentração do ácido clorídrico padronizada $\left(\mathrm{mol} \mathrm{L}^{-1}\right)$

$\mathrm{N}$ = número de mols de hidróxido de potássio que reage com o dióxido de carbono

$\mathrm{MM}_{\mathrm{C}}=$ massa molar do carbono igual a $12 \mathrm{~g} \mathrm{~mol}^{-1}$

PS = peso seco do solo incubado

$\mathrm{f}=$ fator de correção do peso do solo de g para Kg igual a 1000

$\mathrm{d}=$ número de dias de incubação igual a 7

$\mathrm{h}=$ horas de incubação por dia (24h)

Alíquotas de $8 \mathrm{~mL}$ dos extratos foram submetidas à digestão com ácido sulfúrico e ácido fosfórico concentrados e dicromato de potássio $0,066 \mathrm{~mol} \mathrm{~L}^{-1}$, permanecendo em bloco digestor a $100^{\circ} \mathrm{C}$ por 30 minutos após homogeneização. A quantificação do carbono foi realizada através da titulação do dicromato de potássio restante na reação, com sulfato ferroso amoniacal 0,02 $\mathrm{mol} \mathrm{L}^{-1}$ e ferroína como indicador.

Outras alíquotas de $20 \mathrm{~mL}$ dos extratos foram submetidas à digestão a $300^{\circ} \mathrm{C}$ em bloco digestor utilizando-se ácido sulfúrico concentrado e sulfatos de potássio e cobre como catalisadores. O N total nos extratos foi determinado por destilação Kjedahl e titulação com ácido sulfúrico $0,0025 \mathrm{~mol} \mathrm{~L}^{-1}$.

Tanto o carbono quanto o nitrogênio microbianos foram calculados subtraindo-se os valores encontrados para as amostras controles daqueles referentes às amostras fumigadas, considerando-se o fracionamento dos extratos antes das duas determinações (Equações 20 e 21). 


$$
\mathrm{C}_{\mathrm{MIC}}=\left(\mathrm{V}_{\mathrm{NF}}-\mathrm{V}_{\mathrm{F}}\right) \times \mathrm{C}_{\mathrm{SFA}} \times \mathrm{meqC} \times \mathrm{C}_{\mathrm{D}} \times \mathrm{f}_{\mathrm{EX}} \times \mathrm{V}_{\mathrm{E}} \times \mathrm{V}_{\mathrm{A}}^{-1} \times \mathrm{P}_{\mathrm{S}}^{-1} \times \mathrm{f}_{\mathrm{U}} \text { (Equação 20) }
$$

onde:

$\mathrm{C}_{\mathrm{MIC}}=$ carbono da biomassa microbiana em $\mathrm{mg} \mathrm{C} \mathrm{Kg}^{-1}$ solo seco

$\mathrm{V}_{\mathrm{NF}}=$ média do volume de sulfato ferroso amoniacal gasto na titulação da triplicata de amostras não-fumigadas (mL)

$\mathrm{V}_{\mathrm{F}}=$ média do volume de sulfato ferroso amoniacal gasto na titulação da triplicata de amostras fumigadas (mL)

$\mathrm{C}_{\mathrm{SFA}}=$ concentração do sulfato ferroso amoniacal padronizada $\left(\mathrm{mol} \mathrm{L}^{-1}\right)$

meqC $=$ miliequivalente do carbono igual a $1,2 \mathrm{mg}$

$\mathrm{C}_{\mathrm{D}}=$ concentração do dicromato de potássio

$\mathrm{f}_{\mathrm{EX}}=$ fator de rendimento da extração igual a 2,64 correspondente a $37,88 \%$

$\mathrm{V}_{\mathrm{E}}=$ volume total de solução sulfato de potássio utilizado na extração igual a $60 \mathrm{~mL}$

$\mathrm{V}_{\mathrm{A}}=$ volume da alíquota de extrato utilizada na quantificação do carbono igual a $8 \mathrm{~mL}$

$\mathrm{P}_{\mathrm{S}}=$ peso seco de solo pesado para a extração

$\mathrm{f}_{\mathrm{U}}=$ fator de conversão de $\mathrm{mg} \mathrm{g}^{-1}$ para $\mathrm{mg} \mathrm{Kg}^{-1}$

$$
\mathrm{N}_{\mathrm{MIC}}=\left(\mathrm{V}_{\mathrm{F}}-\mathrm{V}_{\mathrm{NF}}\right) \times \mathrm{C}_{\mathrm{AS}} \times \mathrm{MM}_{\mathrm{N}} \times \mathrm{f}_{\mathrm{EX}} \times \mathrm{V}_{\mathrm{E}} \times \mathrm{V}_{\mathrm{A}}^{-1} \times \mathrm{P}_{\mathrm{S}}^{-1} \times \mathrm{f}_{\mathrm{U}} \text { (Equação 21) }
$$

onde:

$\mathrm{N}_{\mathrm{MIC}}=$ nitrogênio da biomassa microbiana em $\mathrm{mg} \mathrm{C} \mathrm{Kg}^{-1}$ solo seco

$\mathrm{V}_{\mathrm{NF}}=$ média do volume de ácido sulfúrico gasto na titulação da triplicata de amostras nãofumigadas $(\mathrm{mL})$

$\mathrm{V}_{\mathrm{F}}=$ média do volume de ácido sulfúrico gasto na titulação da triplicata de amostras fumigadas $(\mathrm{mL})$

$\mathrm{C}_{\mathrm{AS}}=$ concentração do ácido sulfúrico $\left(\mathrm{mol} \mathrm{L}^{-1}\right)$

$\mathrm{MM}_{\mathrm{N}}=$ massa molar do nitrogênio igual a $14 \mathrm{~g}$ mol

$\mathrm{f}_{\mathrm{EX}}=$ fator de rendimento da extração igual a 1,85 correspondente a $54 \%$

$\mathrm{V}_{\mathrm{E}}=$ volume total de solução sulfato de potássio utilizado na extração igual a $60 \mathrm{~mL}$

$\mathrm{V}_{\mathrm{A}}=$ volume da alíquota de extrato utilizada na quantificação do carbono igual a $20 \mathrm{~mL}$

$\mathrm{P}_{\mathrm{S}}=$ peso seco de solo pesado para a extração

$\mathrm{f}_{\mathrm{U}}=$ fator de conversão de $\mathrm{mg} \mathrm{g}^{-1}$ para $\mathrm{mg} \mathrm{Kg}^{-1}$ 
$\mathrm{O}$ quociente metabólico $\left(\mathrm{qCO}_{2}\right)$ foi determinado pela relação $\left(\mathrm{C}-\mathrm{CO}_{2}\right.$ liberado/ $\left.\mathrm{C}_{\mathrm{MIC}}\right)$ segundo metodologia proposta por Anderson e Domsch (1993), e o quociente microbiano (qMIC) foi calculado pela razão entre o $\mathrm{C}_{\mathrm{MIC}}$ e o COT. Também foi calculada a razão $\mathrm{C} / \mathrm{N}$ microbiana $\left(\mathrm{C}_{\mathrm{MIC}} / \mathrm{N}_{\mathrm{MIC}}\right)$.

Para a obtenção dos espectros de solos, as amostras foram secas ao ar, trituradas em moinho de bolas, passadas em peneiras de $0,250 \mathrm{~mm}$ e analisadas em espectrômetros no infravermelho próximo $\left(10000\right.$ a $\left.4000 \mathrm{~cm}^{-1}\right)$ e médio $\left(4000\right.$ a $\left.400 \mathrm{~cm}^{-1}\right)$, com resolução de 16 $\mathrm{cm}^{-1}$ e acumulação de 32 varreduras por espectro. Foram obtidos espectros de refletância transformados automaticamente para absorbância e Kubelka-Munk pelos softwares dos equipamentos. Todos os espectros foram centrados na média e submetidos ao cálculo da $1^{\mathrm{a}}$ e a $2^{\mathrm{a}}$ derivadas com 5 pontos.

Os equipamentos utilizados foram: espectrômetro no infravermelho próximo com refletância difusa Perkin-Elmer, modelo Spectrum 100N, pertencente à Embrapa Instrumentação Agropecuária, e espectrômetro no infravermelho médio com refletância difusa Varian 600-IR com acessório AutoDiff da Pike, pertencente à Embrapa Arroz e Feijão.

\subsection{Análise dos resultados e calibrações}

A fim de explorar os dados, identificando as variáveis que mais diferenciaram as amostras e verificando correlações entre agrupamentos de amostras e agrupamentos de variáveis, foi utilizada a análise de componentes principais (PCA). Os resultados das análises químicas de referência também foram submetidos à regressão com os espectros de absorbância utilizando a técnica de regressão PLS.

O método PLS foi aplicado em $80 \%$ das amostras e esta calibração foi validada durante o cálculo PLS (validação cruzada) e também através da previsão dos atributos para os $20 \%$ restantes das amostras (validação externa). Com a utilização deste método estatístico foram testados separadamente os modelos de calibração obtidos com 5 subgrupos de amostras 
de localidades e vegetação diferentes (CNPAF, CPPSE, MATAS, MANEJADOS, TODOS), para cada uma das técnicas, NIRS e DRIFTS. As amostras de validação externa foram escolhidas a partir de gráficos de scores provenientes de PCA com amostras de cada subgrupo, selecionando aleatoriamente $20 \%$ das amostras de forma representativa.

Os parâmetros utilizados para comparar a eficiência de cada modelo de calibração construído foram: o número de fatores necessários na calibração, os erros de validação cruzada e externa (SEV e Erro\%), o coeficiente de regressão linear entre os dados preditos e medidos (RVC e RVE), assim como a inclinação e intercepto desta reta. De acordo com os resultados para RVE, os modelos foram classificados como $\mathrm{A}, \mathrm{B}$ ou $\mathrm{C}$ conforme descrito por Chang et al. (2001). A escolha dos melhores modelos foi feita com base em todos os parâmetros e não somente de acordo com esta classificação proposta por Chang et al. (2001), pois bons modelos podem ser obtidos com coeficientes de correlação abaixo de 0,5 dependendo da faixa de valores de referência.

Tanto a PCA quanto a PLS utilizaram os espectros inteiros, sem seleção de bandas, e foram calculadas pelo software Pirouette versão 3.11, adquirido pela Embrapa Instrumentação Agropecuária. 


\section{RESULTADOS E DISCUSSÃo}

\subsection{Características dos solos coletados}

Os solos provenientes da fazenda Canchim da Embrapa Pecuária Sudeste no município de São Carlos (PS) e os solos originários da fazenda Capivara da Embrapa Arroz e Feijão, em Santo Antônio de Goiás (AF), foram classificados quanto ao uso do solo e a textura, conforme detalhado na Tabela 3.

Tabela 3 Classificação dos solos coletados segundo o uso do solo e a textura

\begin{tabular}{|c|c|c|c|c|c|}
\hline Amostra & Uso do solo & Textura & Amostra & Uso do solo & Textura \\
\hline PS1 & Mata & Argila & PS30 & Mata & Areia Franca \\
\hline PS2 & Mata & Argila & PS31 & Mata & Franco Argila Arenoso \\
\hline PS3 & Mata & Argila & PS32 & Mata & Franco Argila Arenoso \\
\hline PS4 & Mata & Argila & PS33 & Mata & Argila \\
\hline PS5 & Mata & Argila & PS34 & Mata & Argila Arenosa \\
\hline PS6 & Mata & Franco Argila Arenoso & PS35 & Mata & Franco Argila Arenoso \\
\hline PS7 & Mata & Franco Argiloso & PS36 & Cultura & Franco Argila Arenoso \\
\hline PS8 & Mata & Franco Argila Arenoso & PS37 & Cultura & Franco Argila Arenoso \\
\hline PS9 & Mata & Franco Argila Arenoso & PS38 & Pastagem & Franco Arenoso \\
\hline PS10 & Mata & Franco Arenoso & PS39 & Pastagem & Areia Franca \\
\hline PS11 & Pastagem & Franco Argila Arenoso & PS40 & Pastagem & Franco Arenoso \\
\hline PS12 & Mata & Franco Argila Arenoso & PS41 & Mata & Franco Arenoso \\
\hline PS13 & Cultura & Franco Argila Arenoso & PS42 & Pastagem & Franco Argila Arenoso \\
\hline PS14 & Cultura & Franco Argila Arenoso & PS43 & Pastagem & Argila Arenosa \\
\hline PS15 & Pastagem & Franco Argila Arenoso & PS44 & Pastagem & Franco Argila Arenoso \\
\hline PS16 & Cultura & Argila & PS45 & Pastagem & Franco Argila Arenoso \\
\hline PS17 & Pastagem & Argila Arenosa & PS46 & Pastagem & Franco Argila Arenoso \\
\hline PS18 & Cultura & Muito Argiloso & PS47 & Mata ciliar & Franco Argila Arenoso \\
\hline PS19 & Cultura & Argila Arenosa & PS48 & Pastagem & Franco Argila Arenoso \\
\hline PS20 & Pastagem & Muito Argiloso & PS49 & Pastagem & Argila Arenosa \\
\hline PS21 & Pastagem & Muito Argiloso & PS50 & Pastagem & Argila \\
\hline PS22 & Pastagem & Muito Argiloso & PS51 & Pastagem & Argila \\
\hline PS23 & Pastagem & Muito Argiloso & PS52 & Pastagem & Franco Argila Arenoso \\
\hline PS24 & Pastagem & Argila Arenosa & PS53 & Pastagem & Argila \\
\hline PS25 & Mata & Franco Arenoso & PS54 & Pastagem & Argila \\
\hline PS26 & Mata & Franco Arenoso & PS55 & Pastagem & Argila \\
\hline PS27 & Mata & Areia Franca & PS56 & Pastagem & Argila \\
\hline PS28 & Mata & Franco Arenoso & PS57 & Pastagem & Argila \\
\hline PS29 & Mata & Areia Franca & & & \\
\hline
\end{tabular}




\begin{tabular}{|c|c|c|c|c|c|}
\hline Amostra & Uso do solo & Textura & Amostra & Uso do & Textura \\
\hline AF1 & Cultura & nd & AF47 & Pastagem & Argila \\
\hline AF2 & Cultura & nd & AF48 & Pastagem & Argila \\
\hline AF3 & Cultura & nd & AF49 & Pastagem & Argila \\
\hline AF4 & Cultura & nd & AF50 & Pastagem & Argila \\
\hline AF5 & Cultura & nd & AF51 & Pastagem & Argila \\
\hline AF6 & Cultura & nd & AF52 & Pastagem & Argila \\
\hline AF7 & Cultura & nd & AF53 & Pastagem & Argila \\
\hline AF8 & Cultura & nd & AF54 & Pastagem & Muito Argiloso \\
\hline AF9 & Cultura & nd & AF55 & Pastagem & Muito Argiloso \\
\hline AF10 & Cultura & nd & AF56 & Pastagem & Muito Argiloso \\
\hline AF11 & Cultura & nd & AF57 & Pastagem & Muito Argiloso \\
\hline AF12 & Cultura & nd & AF58 & Pastagem & Muito Argiloso \\
\hline AF13 & Cultura & nd & AF59 & Pastagem & Muito Argiloso \\
\hline AF14 & Cultura & nd & AF60 & Pastagem & Muito Argiloso \\
\hline AF15 & Cultura & nd & AF61 & Mata & Muito Argiloso \\
\hline AF16 & Cultura & nd & AF62 & Pastagem & Muito Argiloso \\
\hline AF17 & Cultura & nd & AF63 & Pastagem & Muito Argiloso \\
\hline AF18 & Cultura & nd & AF64 & Mata & Muito Argiloso \\
\hline AF19 & Cultura & nd & AF65 & Mata & Muito Argiloso \\
\hline AF20 & Cultura & nd & AF66 & Mata & Muito Argiloso \\
\hline AF21 & Cultura & nd & AF67 & Mata & Muito Argiloso \\
\hline AF22 & Cultura & nd & AF68 & Mata & Muito Argiloso \\
\hline AF23 & Cultura & nd & AF69 & Mata & Muito Argiloso \\
\hline AF24 & Cultura & nd & AF70 & Mata & Muito Argiloso \\
\hline AF25 & Cultura & nd & AF71 & Mata & nd \\
\hline AF26 & Cultura & nd & AF72 & Mata & Muito Argiloso \\
\hline AF27 & Cultura & nd & AF73 & Mata & Muito Argiloso \\
\hline AF28 & Cultura & nd & AF74 & Mata & Muito Argiloso \\
\hline AF29 & Cultura & nd & AF75 & Cultura & Muito Argiloso \\
\hline AF30 & Cultura & nd & AF76 & Cultura & Argila \\
\hline AF31 & Cultura & nd & AF77 & Cultura & Argila \\
\hline AF32 & Cultura & nd & AF78 & Cultura & Argila \\
\hline AF33 & Cultura & nd & AF79 & Cultura & Argila \\
\hline AF34 & Cultura & nd & AF80 & Cultura & Argila \\
\hline AF35 & Cultura & nd & AF81 & Cultura & Muito Argiloso \\
\hline AF36 & Cultura & nd & AF82 & Cultura & Argila \\
\hline AF37 & Cultura & nd & AF83 & Pastagem & Muito Argiloso \\
\hline AF38 & Cultura & nd & AF84 & Pastagem & Muito Argiloso \\
\hline AF39 & Cultura & nd & AF85 & Pastagem & Argila \\
\hline AF40 & Cultura & nd & AF86 & Pastagem & Argila \\
\hline AF41 & Mata & nd & AF87 & Pastagem & Argila \\
\hline AF42 & Mata & nd & AF88 & Pastagem & Argila \\
\hline AF43 & Mata & nd & AF89 & Pastagem & Argila \\
\hline AF44 & Pastagem & Argila & AF90 & Integração & Argila \\
\hline AF45 & Pastagem & Argila & AF91 & Integração & Argila \\
\hline AF46 & Pastagem & Argila & AF92 & Integração & Muito Argiloso \\
\hline
\end{tabular}




\begin{tabular}{ccc}
\hline Amostra & Uso do solo & Textura \\
\hline AF93 & Integração & Muito Argiloso \\
AF94 & Integração & Argila \\
AF95 & Integração & Argila \\
AF96 & Integração & Argila \\
AF97 & Integração & Argila \\
AF98 & Integração & Argila \\
AF99 & Integração & Muito Argiloso \\
AF100 & Mata ciliar & Argila \\
AF101 & Mata ciliar & Argila \\
AF102 & Mata ciliar & Argila \\
AF103 & Mata ciliar & Argila \\
\hline
\end{tabular}

\begin{tabular}{ccc}
\hline Amostra & Uso do & Textura \\
\hline AF104 & Mata ciliar & Argila \\
AF105 & Mata ciliar & Argila \\
AF106 & Mata ciliar & Muito Argiloso \\
AF107 & Mata ciliar & Argila \\
AF108 & Mata ciliar & Argila \\
AF109 & Mata ciliar & Argila \\
AF110 & Pastagem & Argila \\
AF111 & Pastagem & Argila \\
AF112 & Pastagem & Argila \\
AF113 & Pastagem & Argila \\
AF114 & Pastagem & Argila \\
\hline
\end{tabular}

As amostras de solo descritas na Tabela 3 apresentaram diferentes valores para os atributos do solo mensurados com o uso dos métodos de referência. A faixa de valores para cada um desses atributos e o desvio padrão associado são apresentados na Tabela 4.

Tabela 4 Atributos do solo quantificados pelos métodos de referência

\begin{tabular}{|c|c|c|c|c|c|}
\hline & Valor mínimo & Valor máximo & Média & Desvio Padrão Médio & $\mathrm{CV}^{1}(\%)$ \\
\hline $\mathbf{C}_{\text {MIC }}\left(\mathrm{mg} \mathrm{Kg}^{-1}\right.$ solo $)$ & 28,29 & 984,89 & 304,49 & 10,69 & 3,52 \\
\hline $\mathbf{N}_{\text {MIC }}\left(\mathrm{mg} \mathrm{Kg}^{-1}\right.$ solo $)$ & 7,15 & 385,29 & 71,72 & 7,93 & 11,06 \\
\hline $\mathbf{R B}\left(\mathrm{mg} \mathrm{C}-\mathrm{CO}_{2} \mathrm{Kg}^{-1} \mathrm{~h}^{-1}\right)$ & $-0,05$ & 8,43 & 1,99 & 0,04 & 2,01 \\
\hline $\mathbf{q C O}_{2}\left(\mu \mathrm{g} \mathrm{C}^{-\mathrm{CO}_{2}} \mathrm{mg} \mathrm{C}^{-1} \mathrm{~h}^{-1}\right)$ & $-0,20$ & 42,86 & 7,77 & 0,43 & 5,53 \\
\hline $\mathbf{C N}_{\mathrm{MIC}}$ & 0,64 & 39,80 & 5,66 & 0,82 & 14,49 \\
\hline COT ( $\mathrm{g} \mathrm{Kg}^{-1}$ solo) & 2,34 & 53,82 & 28,40 & $\mathrm{nd}^{2}$ & nd \\
\hline $\mathbf{q M I C}\left(\mathrm{mg} \mathrm{g}^{-1}\right)$ & 0,95 & 75,71 & 11,27 & nd & nd \\
\hline CT $(\%)$ & 0,27 & 5,29 & 2,48 & nd & $3 \%^{3}$ \\
\hline NT (\%) & 0,11 & 1,96 & 0,84 & nd & nd \\
\hline CN & 0,43 & 20,59 & 8,47 & nd & nd \\
\hline ARGILA ( $\mathrm{g} \mathrm{Kg}^{-1}$ solo) & 96,00 & 678,80 & 465,52 & nd & nd \\
\hline SILTE $\left(\mathrm{g} \mathrm{Kg}^{-1}\right.$ solo $)$ & 7,20 & 374,40 & 86,11 & nd & nd \\
\hline AREIA $\left(\mathrm{g} \mathrm{Kg}^{-1}\right.$ solo $)$ & 166,80 & 866,80 & 448,36 & nd & nd \\
\hline pH & 4,0 & 7,2 & 5,76 & nd & nd \\
\hline
\end{tabular}

Os valores de carbono total e de carbono orgânico total são muito semelhantes (multiplicam-se os valores de CT em \% por 10 para obter dados em $\mathrm{g} \mathrm{Kg}^{-1}$ ). Seus máximos se devem principalmente à incorporação de diversas amostras de solo preservado, sendo o COT e o CT máximos comparáveis àquele obtido por Carvalho (2005) para matas plantadas em 
Campos do Jordão $\left(51,71 \mathrm{~g} \mathrm{Kg}^{-1}\right)$. O valor médio observado para COT foi superior ao encontrado por Alvarenga (1999) para solos de cerrado $\left(16,6 \mathrm{~g} \mathrm{Kg}^{-1}\right)$. No entanto, a média dos conteúdos de carbono orgânico dos solos de mata avaliados no presente trabalho $\left(37,34 \mathrm{~g} \mathrm{Kg}^{-}\right.$ $\left.{ }^{1}\right)$ não foram superiores às medidas realizadas por Carvalho (2005) em porções de mata atlântica $\left(43,7\right.$ a 47,5 $\left.\mathrm{g} \mathrm{Kg}^{-1}\right)$ nem àquelas encontradas para a região de floresta amazônica estudada por Moreira e Malavolta (2004) (42,77 e 47,70 $\left.\mathrm{g} \mathrm{Kg}^{-1}\right)$.

O $\mathrm{C}_{\mathrm{MIC}}$ médio se assemelha ao encontrado por Alvarenga (1999) para pastagens plantadas $\left(349,5 \mathrm{mg} \mathrm{Kg}^{-1}\right)$, refletindo o maior número de áreas amostradas sob este uso do solo. Por sua vez, o resultado médio obtido para qMIC foi de $11,27 \pm 0,79$, atribuindo a $\mathrm{C}_{\mathrm{MIC}}$ uma participação de, em média, 1,13 \% no carbono orgânico total, enquadrando-se dentro da faixa de 1 a 4\%, proposta por Jenkinson e Ladd (1981). A faixa obtida neste trabalho, entretanto, foi bem mais ampla, variando de $0,1 \%$ a $7,8 \%$.

Os valores de nitrogênio total estão dentro de uma faixa mais extensa que aquela esperada para latossolos (1,1 a 1,8 $\left.\mathrm{g} \mathrm{Kg}^{-1}\right)$, indicando a amostragem de solos de outras classes e a adubação nitrogenada de várias áreas estudadas. Com relação à determinação do nitrogênio microbiano, observa-se que está sujeita a maiores desvios que a determinação das várias frações de carbono, sendo o CV médio maior que $10 \%$ e, consequentemente, $14,49 \%$ para a relação $\mathrm{C} / \mathrm{N}$ microbiana. Isto pode ser explicado pelo grande número de etapas envolvido nesta quantificação, assim como pela perda de amônia durante a destilação.

A relação C/N não chegou a 30, demonstrando que nesses solos não havia uma grande quantidade de material resistente à decomposição. Já os resultados da razão $\mathrm{C} / \mathrm{N}$ microbiana foram agrupados, neste trabalho, em 5 faixas: 0 a 2,96 (faixa 1); 3,01 a 4,96 (faixa 2); 5,09 a 6,88 (faixa 3); 7,11 a 8,96 (faixa 4) e 9,02 a 15,09 (faixa 5). A faixa 2 indicou predominância de bactérias nesses solos e a faixa 5, a predominância de biomassa fúngica. É possível visualizar as faixas através de uma PCA com dados de $\mathrm{C}_{\text {MIC }}, \mathrm{N}_{\text {MIC }}$ e $\mathrm{CN}_{\text {MIC. }}$. Dessa forma, nas 
amostras destacadas em roxo predominam as bactérias, enquanto que naquelas destacadas em rosa claro há maior ocorrência de fungos (Figura 15).
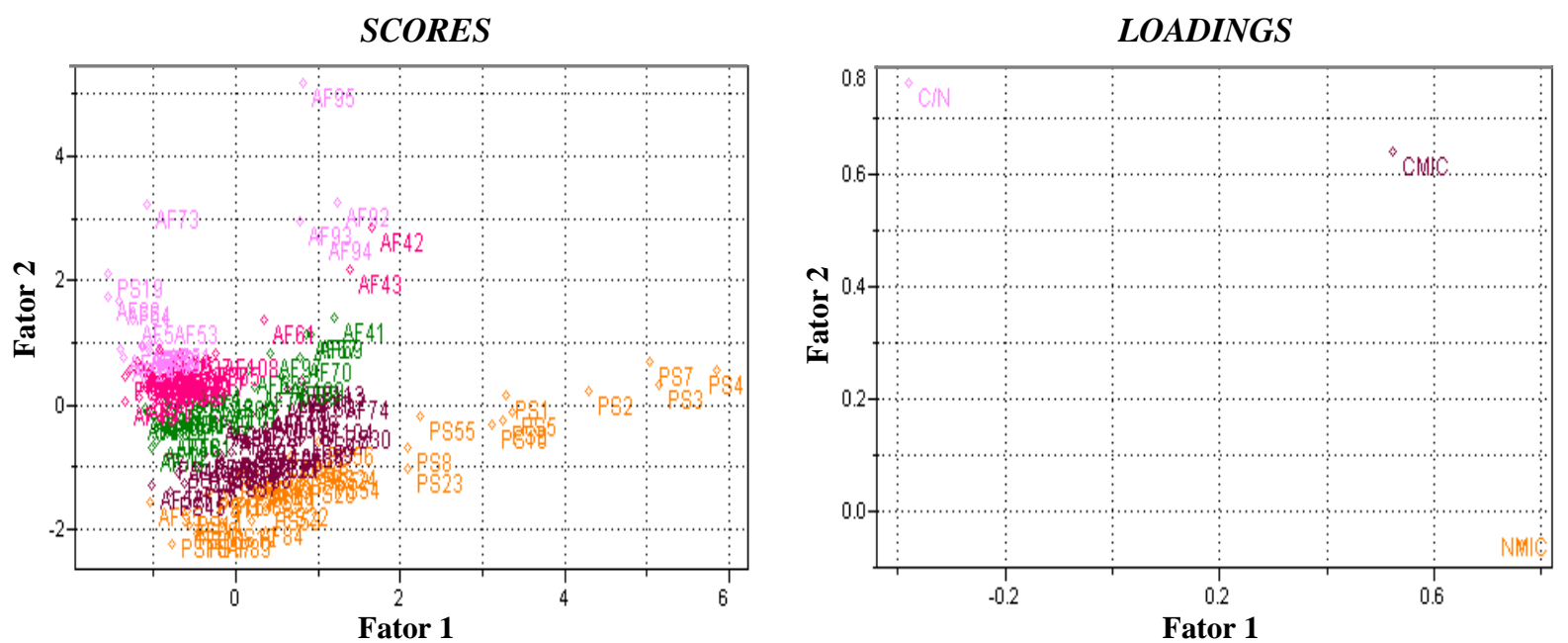

Figura 15 Gráficos de scores e loadings com faixas de razão C/N. Scores: em amostras da laranja faixa 1, roxo faixa 2 , verde faixa 3 , rosa escuro faixa 4 , rosa claro faixa 5.

Verifica-se que os solos da Embrapa Pecuária Sudeste, especialmente os solos de mata nativa, são ricos em biomassa bacteriana, enquanto que os solos da Embrapa Arroz e Feijão se distribuem dentro das faixas 2 a 5 .

Pela média do quociente metabólico, há um razoável equilíbrio da comunidade microbiana da maioria desses solos, porém o valor máximo mostra que alguns estão muito longe do equilíbrio entre a perda de carbono pela respiração e a sua incorporação na biomassa microbiana, havendo uma taxa de mineralização de carbono muito rápida. $\mathrm{O}$ seu desvio foi médio, devido ao erro associado à quantificação de $\mathrm{C}_{\mathrm{MIC}}$, já que o método utilizado para quantificar a respiração basal do solo se mostrou bem preciso. Tal precisão em RB não era esperada devido à evaporação da solução alcalina em consequência de possíveis falhas no isolamento do ambiente em que a liberação do $\mathrm{CO}_{2}$ é medida.

Estes resultados apresentados também foram utilizados para verificar o potencial de discriminação das diferentes técnicas e variáveis, o que pode ser visualizado nos gráficos de scores da PCA apresentados posteriormente para cada grupo de atributos do solo. 


\subsection{Espectros de NIRS}

É possível identificar três principais regiões nos espectros no infravermelho próximo situando-se em torno de $7000 \mathrm{~cm}^{-1}, 5200 \mathrm{~cm}^{-1} \mathrm{e} 4500 \mathrm{~cm}^{-1}$. A Figura 16 apresenta alguns espectros de NIRS representativos das amostras analisadas.

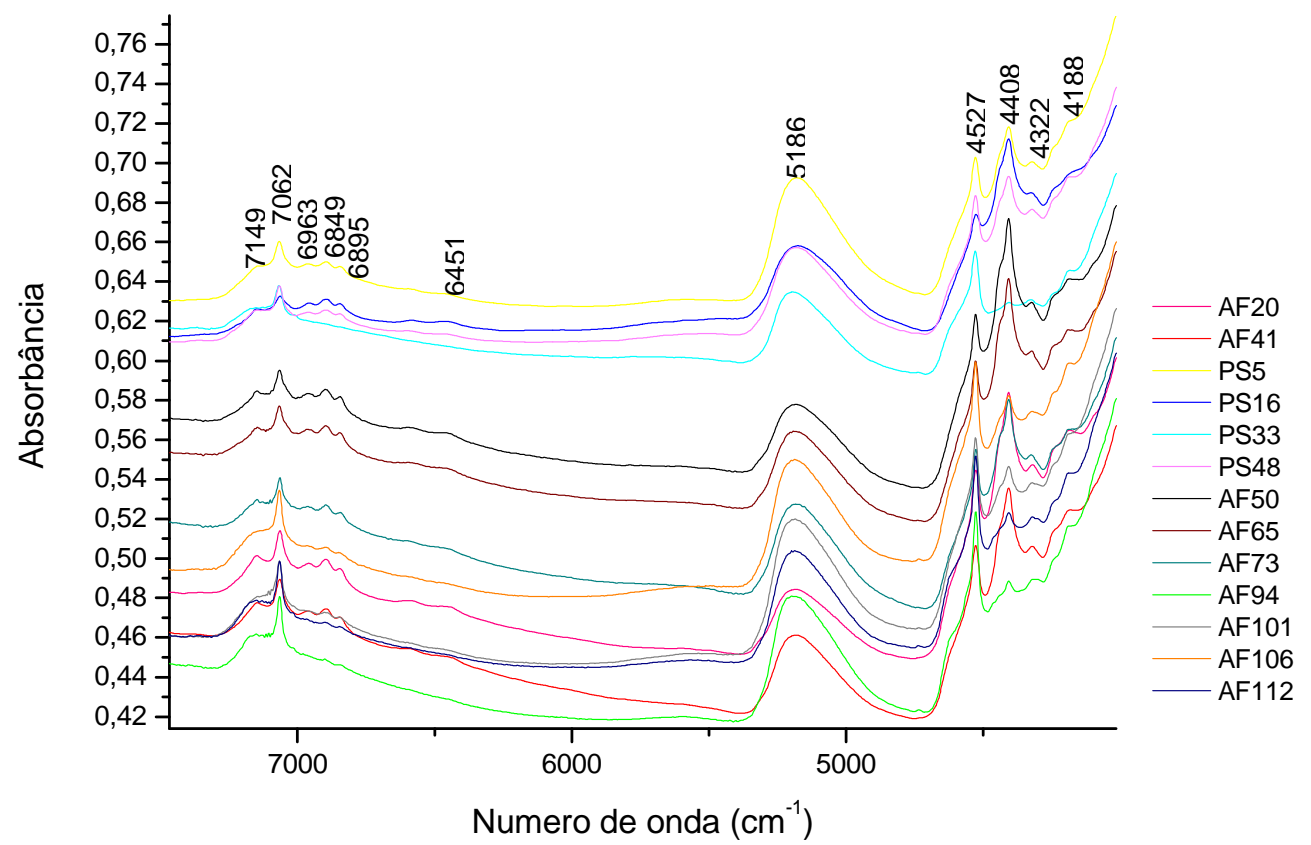

Figura 16 Espectros de absorbância em infravermelho próximo com bandas assinaladas.

É difícil realizar a interpretação dos espectros em NIRS, visto que são constituídos essencialmente de bandas de combinação e harmônicas. Apesar disso, faz-se aqui uma tentativa de atribuição das bandas observadas, com base em informações anteriormente publicadas.

O sinal em $7149 \mathrm{~cm}^{-1}$ pode ser atribuído a vibrações $\mathrm{OH}$ de $\mathrm{Al}(\mathrm{OH})$ indicando a presença de caulinita e/ou montmorilonita. Já aquele mais definido em $7062 \mathrm{~cm}^{-1}$ e outro pouco visível em $6963 \mathrm{~cm}^{-1}$ podem ser resultantes da $1^{\text {a }}$ harmônica da absorção de $\mathrm{OH}$ de alcoóis e fenóis. É possível atribuir também a absorção em $7062 \mathrm{~cm}^{-1}$ às vibrações $\mathrm{OH}$ de moléculas de água adsorvidas pela montmorilonita e à combinação de estiramentos $\mathrm{CH}$. 
A banda em $6895 \mathrm{~cm}^{-1}$ e a seguinte banda sobreposta em $6849 \mathrm{~cm}^{-1}$ podem ser atribuídas, respectivamente, às primeiras harmônicas das absorções relativas a vibrações de estiramentos de $\mathrm{O}-\mathrm{H}$ de carboidratos como amido e N-H de uréia.

Em $6451 \mathrm{~cm}^{-1}$ tem-se o sinal mais fraco, que pode ser um indicativo da presença de amidas e aminas, enquanto que em $5186 \mathrm{~cm}^{-1}$ tem-se o mais intenso, sempre presente nas amostras de solo, resultante da $1^{\mathrm{a}}$ harmônica do estiramento $\mathrm{CH}$ de grupos metilas, metilenos e etilenos, da absorção por fosfatos orgânicos e de vários outros grupos funcionais presentes em celulose, lignina, amido, pectina e substâncias húmicas, além de água adsorvida por argilominerais como caulinita e montmorilonita.

A região final dos espectros é marcada por duas bandas com absorção máxima bem definida, situadas em $4527 \mathrm{~cm}^{-1}$ e $4408 \mathrm{~cm}^{-1}$, que indicam a presença de caulinita e gibbsita além de combinações entre vibrações de estiramentos de $\mathrm{CH}$, $\mathrm{NH}$ e $\mathrm{OH}$. Também nesta região do espectro são observadas outras duas bandas, menos intensas e pouco definidas, em 4322 $\mathrm{cm}^{-1} \mathrm{e} 4188 \mathrm{~cm}^{-1}$, devido à presença de água adsorvida à gibbsita.

Essas atribuições foram feitas a partir de informações obtidas em Dalmolin et al. (2005), Formaggio e Epiphanio (2001), Demattê et al. (2004, 2005), Workman (1998), R. Rinnan e A. Rinnan (2007) e Vergnoux et al. (2009) estão detalhadas na Tabela 5.

Tabela 5 Atribuições para as bandas observadas nos espectros no infravermelho próximo

\begin{tabular}{cc}
\hline Bandas $\left(\mathbf{c m}^{-1}\right)$ & Atribuições \\
\hline 7149 & vO-H de Al(OH) de caulinita e montmorilonita \\
7062 & vO-H alcoóis e fenóis, vO-H de montmorilonita \\
6963 & vO-H alcoóis e fenóis \\
6895 & vO-H amido \\
6949 & vN-H uréia \\
6451 & vO-H de fosfatos orgânicos e água de caulinita e montmorilonita, $1^{a}$ harmônica de vC-H \\
5186 & Caulinita,gibbsita, combinação de vO-H , vN-H e vC-H \\
4527 & Caulinita \\
4408 & vO-H de água adsorvida por gibbsita \\
4322 & vO-H de água adsorvida por gibbsita \\
4188 &
\end{tabular}


Para visualizar como os diferentes usos do solo podem interferir nos perfis espectrais, os resultados de NIRS também foram plotados para cada subgrupo de amostras sob diferente uso do solo, constituindo-se 5 subgrupos: solos cultivados, solos sob pastagem, solos sob mata nativa, solos sob mata-ciliar e solos sob sistema de integração lavoura-pecuária (Figura 17).
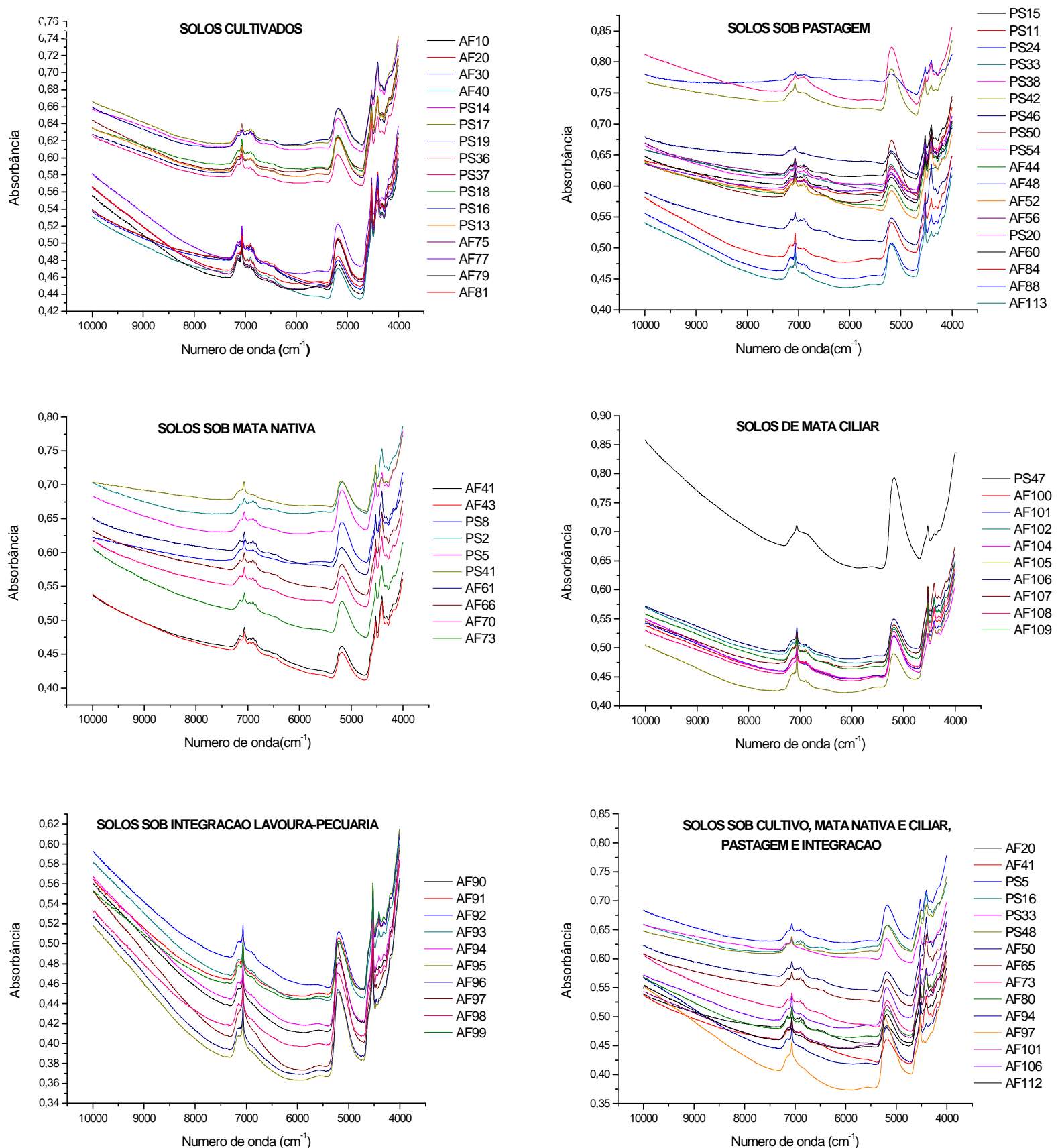

Figura 17 Espectros de absorbância em infravermelho próximo de diferentes subgrupos amostrais, segundo uso do solo: cultivados, com pastagens, matas nativas, matas ciliares e solos de áreas com integração lavourapecuária. 
Percebe-se que o espectro da amostra 47, que possui o maior conteúdo de CT, tem a maior intensidade do sinal em $5186 \mathrm{~cm}^{-1}$, sugerindo alguma correlação. Apesar disso, todas as amostras sob integração lavoura-pecuária e as amostras sob pastagem PS50 e PS38, que possuem intensidade de sinal comparável, não contêm os maiores teores de CT.

Apesar disso, outra região em torno de $11100 \mathrm{~cm}^{-1}$, parcialmente observada nesses espectros já foi correlacionada com matéria orgânica e óxidos de ferro. Alguns trabalhos citados por Dalmolin et al. (2005), exemplificam o comportamento da matéria orgânica, em teores superiores a $17 \mathrm{~g} \mathrm{Kg}^{-1}$, que pode exercer um efeito máscara sobre os sinais de ferro, em refletância.

\subsection{Espectros de DRIFTS}

Os espectros no infravermelho médio trazem grande quantidade de informação sobre os componentes das amostras, havendo maior número de bandas, sobrepostas umas às outras, como se observa na Figura 18.

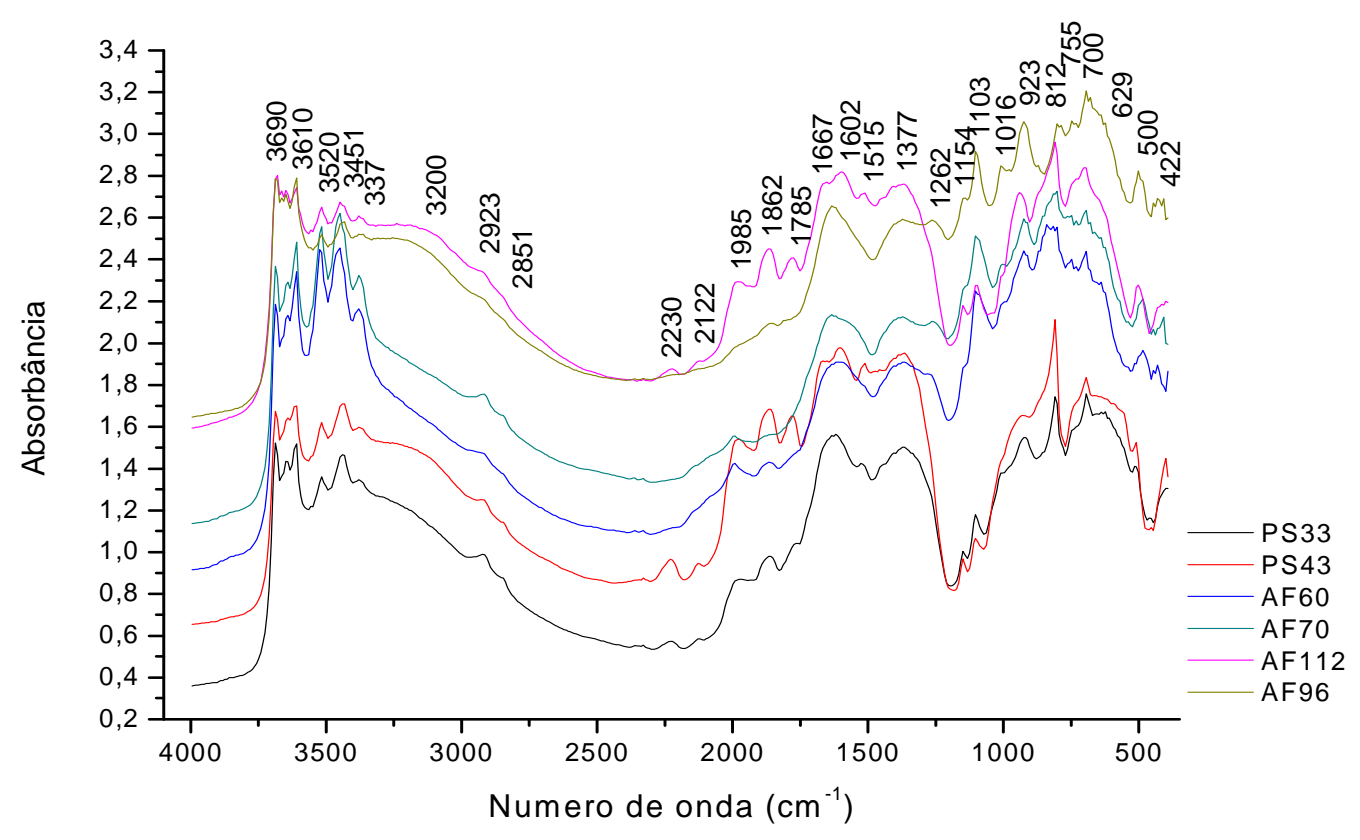

Figura 18 Espectros de absorbância em infravermelho médio com bandas assinaladas. 
Organicamente, uma interpretação dos espectros é possível; entretanto, os sinais observados nas regiões entre 4000 e $3000 \mathrm{~cm}^{-1}$ e entre 1700 e $500 \mathrm{~cm}^{-1}$, ou seja, em grande parte do espectro, devem-se principalmente às absorções por compostos inorgânicos do solo como sílica, caulinita e gibbsita. Torna-se difícil, portanto, uma interpretação individual de cada banda de absorção.

Primeiramente será feita a interpretação com base somente nas funções orgânicas; depois, as regiões que são ocultadas pela sobreposição dos sinais de inorgânicos serão detalhadas.

Na primeira região do espectro (3700 a $3100 \mathrm{~cm}^{-1}$ ) são observadas algumas bandas agudas seguidas de um ombro largo. A banda larga em $3200 \mathrm{~cm}^{-1}$ pode ser atribuída ao estiramento de $\mathrm{OH}(v \mathrm{O}-\mathrm{H})$ de alcoóis e fenóis com ligação de hidrogênio ou ao estiramento de $\mathrm{NH}$ de lactamas $(v \mathrm{~N}-\mathrm{H})$. Já aquela em $3451 \mathrm{~cm}^{-1}$ pode ser também devida ao estiramento de $\mathrm{NH}$ livre $(\mathrm{vN}-\mathrm{H})$ e as bandas agudas em $3610 \mathrm{~cm}^{-1}$ e $3516 \mathrm{~cm}^{-1}$, ao estiramento de $\mathrm{O}-\mathrm{H}$ (vO-H) livre de alcoóis e fenóis.

Em $2923 \mathrm{~cm}^{-1}$ observa-se a absorção de estiramento assimétrico de metileno $\left(\mathrm{v}_{\mathrm{as}} \mathrm{CH}_{2}\right)$ ou aquela resultante do estiramento de $\mathrm{C}-\mathrm{H}$ de aldeídos aromáticos com grupos fortemente eletronegativos na posição orto (vH-CO-Ar-E). As bandas pouco visíveis em $2230 \mathrm{~cm}^{-1} \mathrm{e}$ $2122 \mathrm{~cm}^{-1}$ podem ser atribuídas a sais de amidas.

Em compostos orgânicos isolados, atribui-se a banda em $1985 \mathrm{~cm}^{-1}$ a estiramentos de alcenos acumulados $\left(v \mathrm{C}=\mathrm{C}=\mathrm{CH}_{2}\right)$ e aquela em $1785 \mathrm{~cm}^{-1}$ ao estiramento de carbonilas com o oxigênio menos eletronegativo como em carboxilatos e $\gamma$-lactonas $(v C=O)$. A banda sobreposta em $1667 \mathrm{~cm}^{-1}$ pode ser devida ao estiramento de carbonila de cetonas conjugadas com alcenos $(v \mathrm{C}=\mathrm{O})$. Esta banda também pode ser identificada como banda de amida I (vC $=\mathrm{O}$ de amidas). Já em 1515 e $1602 \mathrm{~cm}^{-1}$ se encontram as bandas de amida II decorrentes 
de deformação angular de $\mathrm{NH}$ ou $\mathrm{NH}_{2}(\delta \mathrm{N}-\mathrm{H})$. Em $1602 \mathrm{~cm}^{-1}$ também pode estar o estiramento de alcenos conjugados com anel aromático (vC=C-Ar).

Na região onde se encontra o sinal em $1377 \mathrm{~cm}^{-1}$, são geralmente observadas a deformação angular simétrica de metila $\left(\delta_{\mathrm{S}} \mathrm{CH}_{3}\right)$ e a deformação angular no plano de $\mathrm{OH}(\delta \mathrm{O}-$ $\mathrm{H})$.

Em $1154 \mathrm{~cm}^{-1}$ observa-se a banda de estiramento de $\mathrm{CO}$ de alquil-éters ou carboidratos, assim como a deformação angular assimétrica fora do plano de metileno $\left(\tau_{\mathrm{as}} \mathrm{CH}_{2}\right)$; em $923 \mathrm{~cm}^{-1}$ a deformação angular assimétrica no plano de $t$-butila $\left(\rho_{\mathrm{as}} \mathrm{CH}\left(\mathrm{CH}_{3}\right)_{3}\right)$ e, na região entre 700 e $812 \mathrm{~cm}^{-1}$, a deformação angular assimétrica fora do plano $(\tau \mathrm{C}-\mathrm{H})$. Essas atribuições feitas através de dados extraídos de Silverstein (2007), Barbosa (2007) e Madari (2006a) estão resumidas na Tabela 6.

Tabela 6 Atribuições orgânicas para as bandas observadas nos espectros no infravermelho médio

\begin{tabular}{|c|c|}
\hline Bandas $\left(\mathrm{cm}^{-1}\right)$ & Atribuições \\
\hline 3610 & vO-H livre \\
\hline 3516 & vO-H livre \\
\hline$\sim 3500$ & $v \mathrm{C}-\mathrm{H}$ \\
\hline 3451 & $v \mathrm{~N}-\mathrm{H}$ livre \\
\hline 3200 & $v \mathrm{O}-\mathrm{H}$ e $v \mathrm{~N}-\mathrm{H}$ com ligações $\mathrm{H}$ \\
\hline 2923 & $v_{\mathrm{as}} \mathrm{CH}_{2}$ aromáticos ou $v \mathrm{H}-\mathrm{CO}-\mathrm{Ar}-\mathrm{E}$ \\
\hline 2122 & $v \mathrm{C} \equiv \mathrm{C}-\mathrm{R}$ \\
\hline 1985 & $v \mathrm{C}=\mathrm{C}=\mathrm{CH}_{2}$ \\
\hline 1785 & $v-\mathrm{CF}=\mathrm{CF}_{2}, v \mathrm{C}=\mathrm{O}$ ou $v \mathrm{O}=\mathrm{C}-\mathrm{X}$ \\
\hline 1667 & $v \mathrm{RC}=\mathrm{CR}_{2}, v \mathrm{C}=\mathrm{O}$ Amida I \\
\hline 1515 e 1602 & Amida II $\delta \mathrm{N}-\mathrm{H}$ \\
\hline 1602 & $v \mathrm{C}=\mathrm{C}-\mathrm{Ar}$ \\
\hline 1377 & $\delta_{\mathrm{s}} \mathrm{CH}_{3}, 1^{\mathrm{a}}$ harm. $\delta \mathrm{H}-\mathrm{C} \equiv \mathrm{C}, \delta \mathrm{O}-\mathrm{H}$ \\
\hline 1154 & $\tau_{\mathrm{as}} \mathrm{CH}_{2}$ \\
\hline 923 & $\rho_{\mathrm{as}} \mathrm{CH}\left(\mathrm{CH}_{3}\right)_{3}$ \\
\hline 700 e 812 & $\tau \mathrm{C}-\mathrm{H}$ \\
\hline
\end{tabular}

As atribuições inorgânicas, descritas na Tabela 7, foram feitas de acordo com informações obtidas em Russell e Fraser (1994), Reeves et al. (2005) e Viscarra-Rossel et al. (2006). 
Tabela 7 Atribuições inorgânicas para as bandas observadas nos espectros no infravermelho médio

\begin{tabular}{cc}
\hline Bandas $\left(\mathbf{c m}^{-1}\right)$ & Atribuições \\
\hline 3690 & vO-H de caulinita, silicatos \\
3660 & vO-H de caulinita \\
3645 & vO-H de caulinita \\
3610 & vO-H de caulinita, vO-H de água em gibbsita e illita \\
3520 & Gibbsita \\
3451 & vO-H de água adsorvida, gibbsita, caulinita \\
3377 & Gibbsita, smectita \\
1985 & Quartzo \\
1862 & Quartzo \\
1785 & Quartzo \\
1667 & Caulinita \\
1602 & Smectita \\
1103 & caulinita, silicatos \\
1016 & caulinita, silicatos \\
923 & Quartzo \\
812 & Illita \\
800 & Quartzo \\
755 & Illita \\
700 & Quartzo \\
563 & Hematita \\
500 & Silicatos \\
403 & Silicatos \\
\hline
\end{tabular}

Verifica-se, desse modo, que as regiões que se estendem de $3200 \mathrm{~cm}^{-1}$ a $2100 \mathrm{~cm}^{-1} \mathrm{e}$ de $1550 \mathrm{~cm}^{-1}$ a $1150 \mathrm{~cm}^{-1}$ refletem quase exclusivamente a presença de compostos orgânicos, não havendo sobreposições com componentes inorgânicos. Viscarra-Rossel et al. (2006) afirmam que a faixa de 1800 a 1190 contribuem positivamente para os scores de compostos orgânicos nas primeiras três PCs em PCA de dados espectrais de solos. Ainda outra pequena faixa foi escolhida por Coleman et al. (1991) como a melhor para estimar o conteúdo de matéria orgânica: entre 800 e $961 \mathrm{~cm}^{-1}$, que corresponde à impressão digital bacteriana de acordo Filip e Hermann (2001).

Analisando os espectros de DRIFTS plotados separadamente por subgrupos amostrais divididos para cada uso do solo (Figura 19), verifica-se que os solos sob pastagem diferem muito entre si, ao contrário dos solos sob lavoura-pecuária, que se assemelham bastante. 

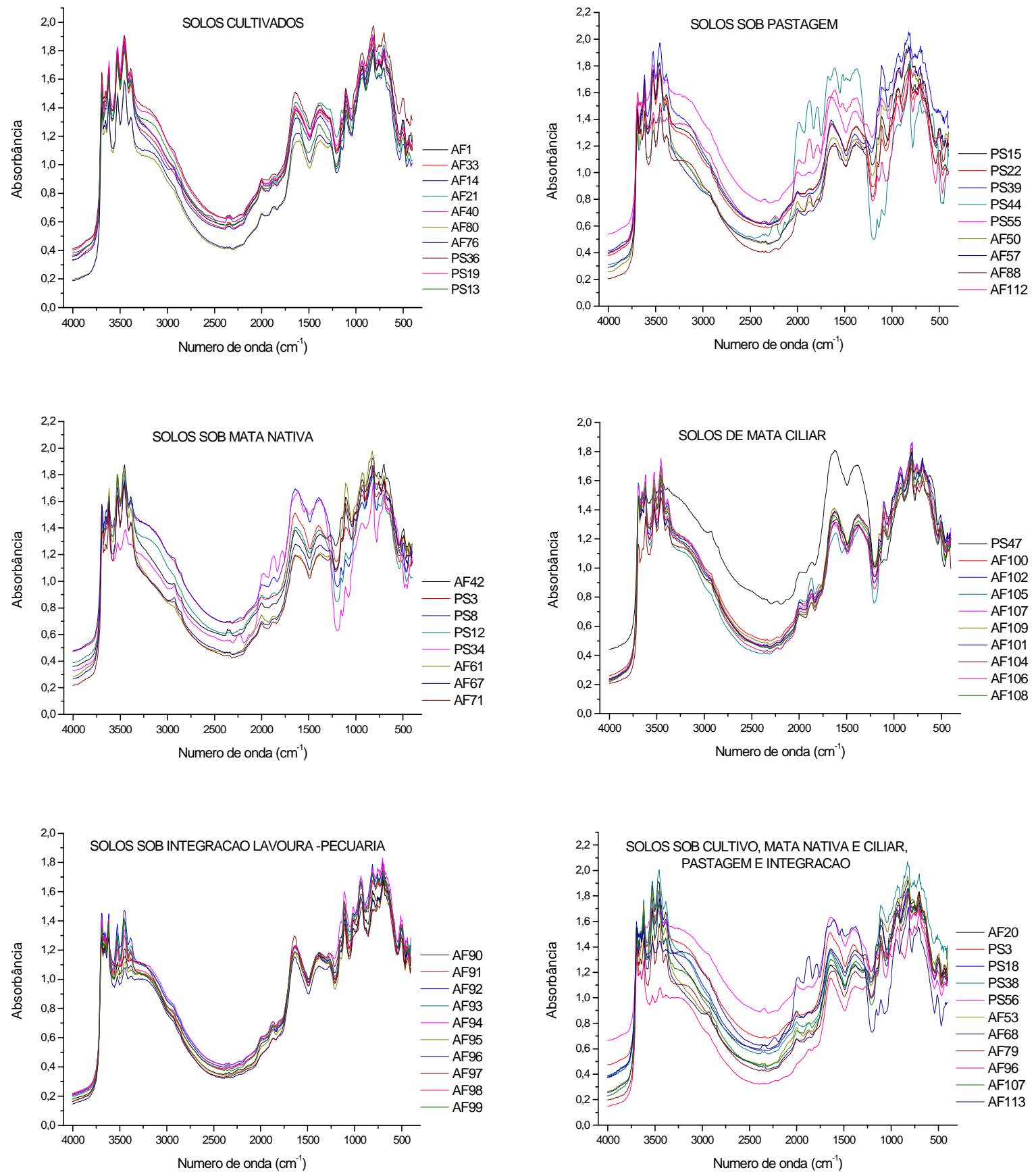

Figura 19 Espectros de absorbância em infravermelho médio de diferentes subgrupos amostrais, segundo uso do solo: cultivados, com pastagens, matas nativas, matas ciliares e solos de áreas com integração lavoura-pecuária.

A amostra PS47 se destacou no grupo matas ciliares, porém seu perfil é o mesmo das amostras coletadas em áreas próximas da Embrapa Pecuária Sudeste em São Carlos (Figura 20). 


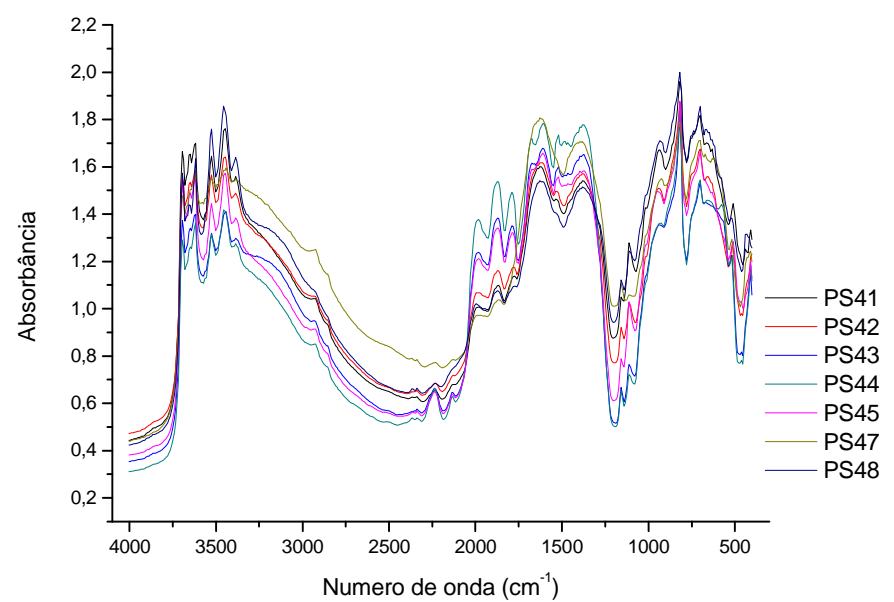

Figura 20 Espectros de amostras de São Carlos coletados em locais próximos.

Os espectros de PS34, AF112 e AF113 (Figura 19), assim como aqueles contidos na Figura 20, apresentaram 3 bandas entre $1750 \mathrm{~cm}^{-1}$ e $2000 \mathrm{~cm}^{-1}$, que não estão presentes em todos os espectros obtidos por DRIFTS. Estes solos não pertencem ao mesmo grupo textural e também não têm o mesmo uso e local de origem. Estas bandas, atribuídas por Reeves (2005) e Viscarra-Rossel (2006) ao quartzo, podem aparecer em solos com baixo conteúdo de matéria orgânica.

Para confirmar esta hipótese foram selecionados quatro espectros de solos com diferentes combinações de teores de areia e carbono orgânico (Figura 21), conforme Tabela 8.

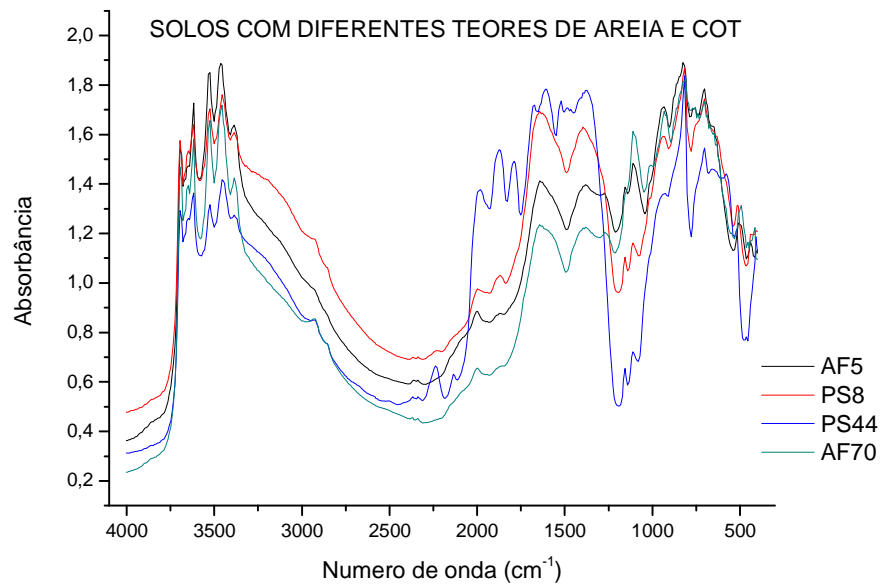

Figura 21 Espectros de solos com diferentes teores de areia e carbono orgânico. 
Tabela 8 Solos com diferentes teores de areia e carbono orgânico

\begin{tabular}{cccc}
\hline Amostra & Areia & COT & Razão Areia/COT \\
\hline PS8 & Alto & Alto & 17,34 \\
PS44 & Alto & Baixo & 185,21 \\
AF70 & Baixo & Alto & 6,06 \\
AF5 & Baixo & Baixo & - \\
\hline
\end{tabular}

A ordem crescente em intensidade de sinais nesta faixa é: AF70, AF5, PS8 e PS44 Assim, é perceptível que quanto menos intenso os sinais entre $2100 \mathrm{~cm}^{-1} \mathrm{e} 1200 \mathrm{~cm}^{-1}$ maior o conteúdo orgânico, e, quanto mais intensos, maior o conteúdo de areia. Mesmo havendo uma quantidade considerável de areia, se o teor de matéria orgânica for alto, estes sinais serão atenuados, como na amostra PS8. Este efeito ocorre com maior intensidade na região das três bandas: $2100 \mathrm{~cm}^{-1}$ e $1750 \mathrm{~cm}^{-1}$.

\subsection{Transformação dos espectros}

A escolha da transformação dos espectros originais de reflectância em espectros de absorbância (A) foi feita após comparação com a transformação Kubelka-Munk . Abaixo é apresentado o espectro de refletância de uma amostra de solo em NIRS tansformado para A e K-M. Os perfis espectrais se assemelham bastante (eixo x), diferindo na intensidade dos sinais (Figura 22).

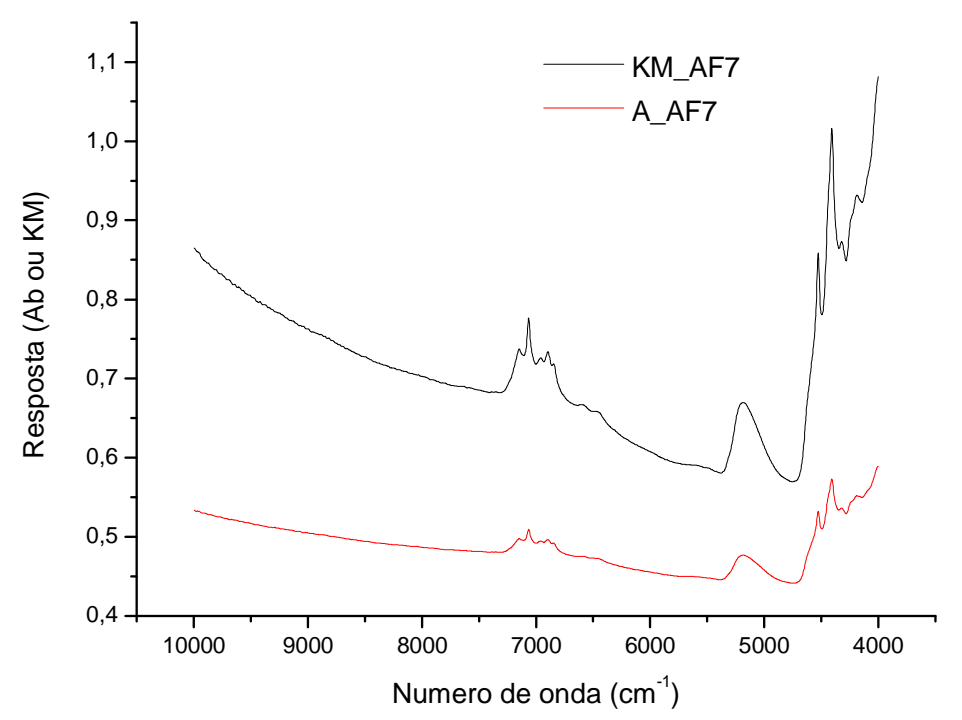

Figura 22 Espectros Absorbância e Kubelka-Munk para a amostra AF7. 
De acordo com Smith (1996), os espectros de absorbância difusa não devem ser utilizados para análise quantitativa e sim a transformação para K-M. Entretanto, atualmente a simples conversão dos espectros de refletância para absorbância tem sido aplicada nas calibrações para propriedades do solo (VISCARRA-ROSSEL et al., 2006; MADARI et al., 2005, 2006; COÛTEAUX et al., 2003; CHANG et al., 2001).

Apesar das diferenças das intensidades de resposta serem maiores com o cálculo de KM, os resultados obtidos nas calibrações por PLS utilizando os espectros de absorbância foram melhores para alguns atributos testados (Tabela 9), optando-se pelo uso da simples transformação com a Equação 6 (-logR). Na avaliação dos modelos de calibração, utilizaramse dados da validação cruzada (RVC e SEV) e dados da validação externa (RVE e erro percentual).

Tabela 9 Comparação entre modelos de calibração calculados com espectros NIRS em A e K-M

\begin{tabular}{ccccccccc}
\hline Modelo & Atributo do solo & $\mathbf{R V C}^{1}$ & SEV $^{2}$ & NF $^{3}$ & Intercepto & Inclinação & RVE $^{4}$ & Erro Médio (\%) \\
\hline TODOS K-M & CMIC & 0,1805 & 175,52 & 6 & 271,96 & 0,12 & 0,1967 & 56,77 \\
TODOS ABS & CMIC & 0,6065 & 127,51 & 7 & 146,28 & 0,59 & 0,8297 & 47,87 \\
TODOS K-M & NMIC & 0,3877 & 69,32 & 3 & 68,80 & 0,26 & 0,6033 & 67,21 \\
TODOS ABS & NMIC & 0,7350 & 51,09 & 7 & 16,34 & 0,75 & 0,9212 & 34,38 \\
TODOS K-M & COT & 0,3745 & 8,36 & 4 & 23,87 & 0,15 & 0,3041 & 17,24 \\
TODOS ABS & COT & 0,7649 & 5,77 & 7 & 0,84 & 4,74 & 0,9519 & 26,07 \\
TODOS K-M & CT & 0,1476 & 0,69 & 2 & 2,02 & $-0,01$ & $-0,0314$ & 33,98 \\
TODOS ABS & CT & 0,2748 & 2,07 & 1 & 1,40 & 0,53 & 0,5028 & 25,04 \\
TODOS K-M & NT & 0,3430 & 0,34 & 3 & 1,30 & 0,21 & 0,1522 & 10,97 \\
TODOS ABS & NT & 0,8451 & 0,42 & 3 & 0,15 & 0,91 & 0,9693 & 57,15 \\
\hline
\end{tabular}

${ }^{1} \mathrm{RVC}=$ coeficiente de regressão obtido pela validação cruzada; ${ }^{2} \mathrm{SEV}=$ erro de validação (ver Equação 9);

${ }^{3} \mathrm{NF}=$ número de fatores ou PCs utilizados no cálculo da PLS; ${ }^{4} \mathrm{RVE}=$ coeficiente de regressão obtido pela validação externa.

Outra transformação dos dados utilizada foi o cálculo de derivada. Foram testadas a primeira e a segunda derivadas com 5 pontos de intervalo conforme ilustrado na Figura 23. 
Modelos de calibração foram construídos com os espectros de absorbância sem transformação $\left(\mathrm{d}_{0}\right)$ e com o cálculo da primeira e segunda derivadas $\left(\mathrm{d}_{1}\right.$ e $\left.\mathrm{d}_{2}\right)$ para fins de comparação. Esses resultados estão contidos nos Anexos II e III. A transformação com a primeira derivada foi escolhida como padrão para os próximos modelos obtidos com NIRS e DRIFTS, para correção de problemas de linha de base e aumento da resolução sem incremento significativo de ruído.
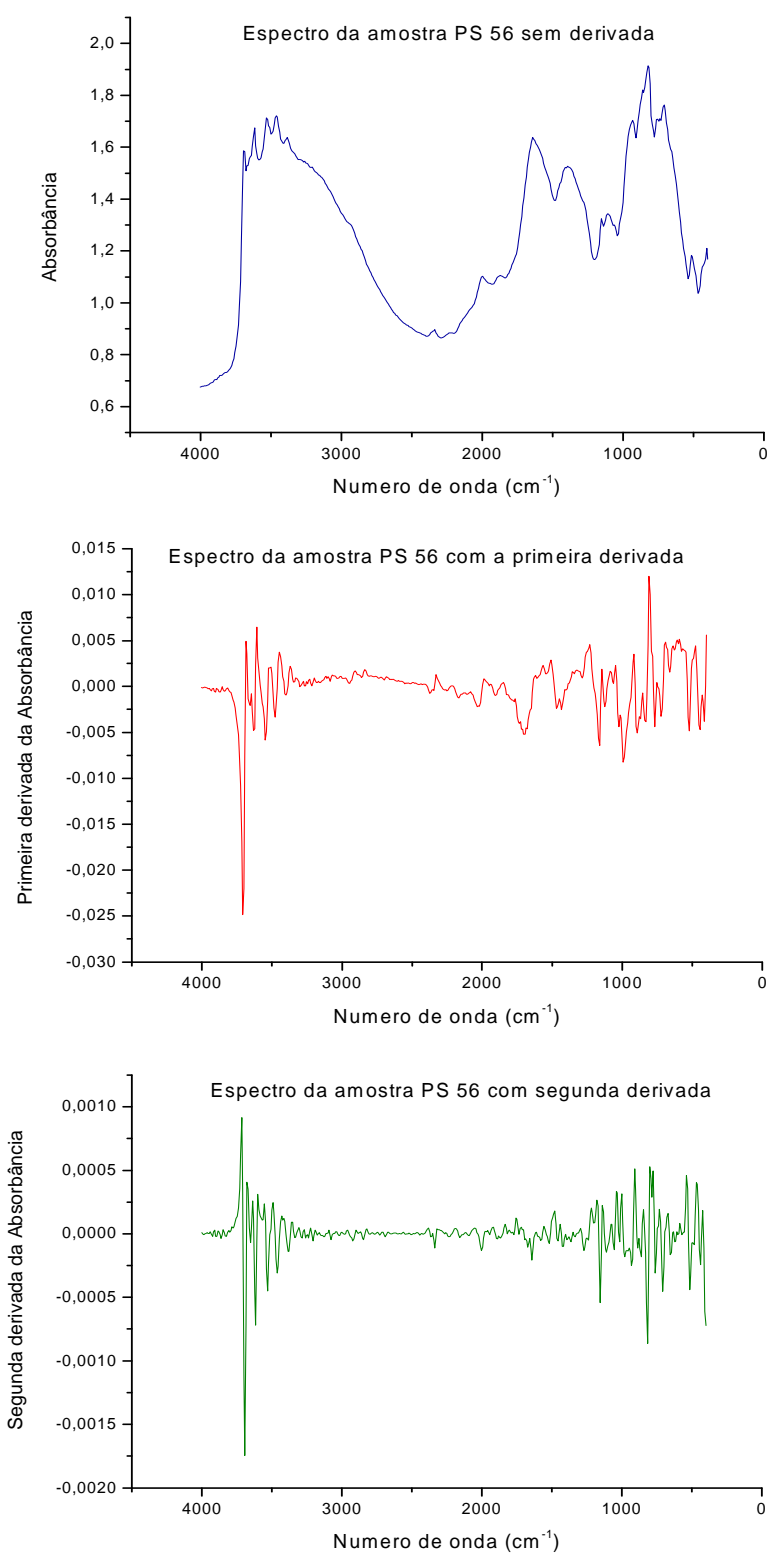

Figura 23 Espectros DRIFTS da amostra PS 56 sem transformação e com o cálculo da $1^{\mathrm{a}}$ e $2^{\mathrm{a}}$ derivadas com 5 pontos de intervalo. 


\subsection{Análise exploratória dos dados espectrais}

\subsubsection{Espectroscopia no infravermelho próximo}

Foi realizada uma análise de componentes principais com os dados espectrais obtidos por NIRS, após $1^{\text {a }}$ derivada com 5 pontos e centrados na média, utilizando-se inicialmente 10 PCs. Com os dados da validação cruzada utilizada na PCA, foram gerados o gráfico do erro de validação (PRESS VAL) e o gráfico da variância total explicada versus o número de fatores (Figura 24).
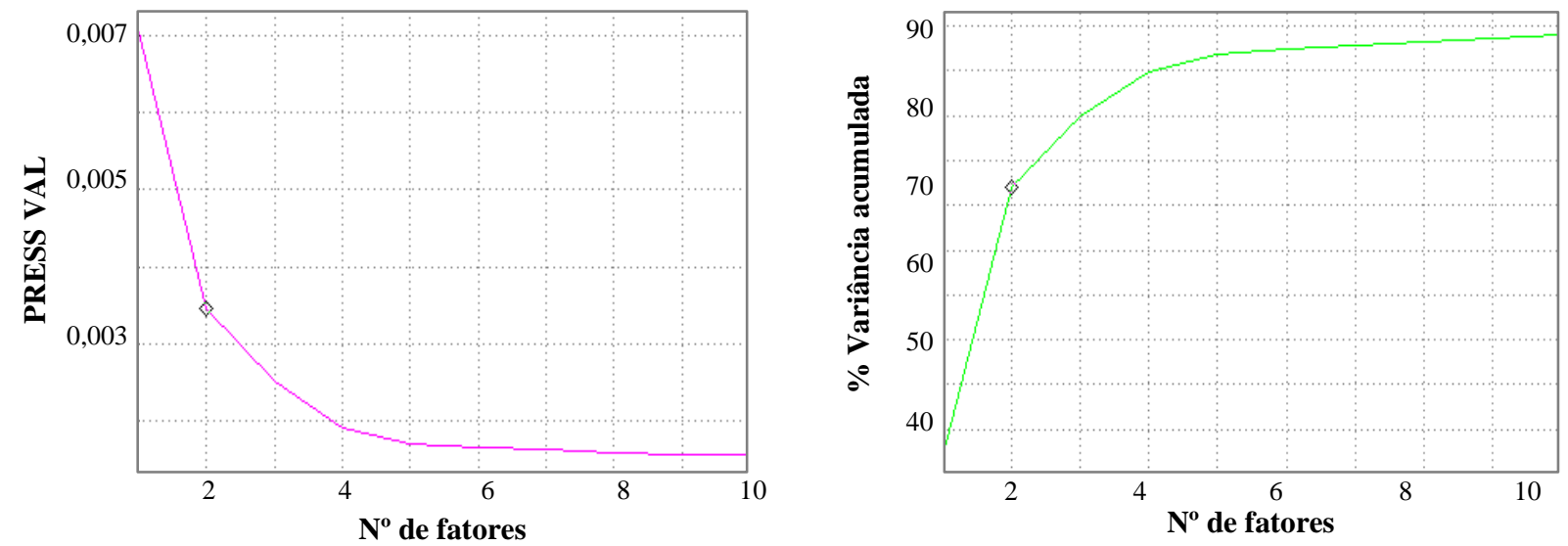

Figura 24 Gráficos de PRESS VAL e \% Variância acumulada versus número de fatores incluídos na PCA NIRS.

Observa-se uma diminuição do erro à medida que são inclusos mais fatores no modelo criado na PCA. Em geral, escolhe-se o número de fatores que provoca uma queda mais acentuada nos valores de PRESS VAL, acumulando-se o máximo de variância explicada pelas PCs.

A tabela gerada pelo software Pirouette (Tabela 10) fornece, os valores de PRESS VAL e variância, visualizados nos gráficos, a cada fator adicionado. A partir desses dados, verifica-se, que com 2 fatores, acumula-se uma variância de 72,10\%, explicada por essas duas componentes principais, e atinge-se um valor baixo de PRESS VAL, igual a 0,003. 
Tabela 10 Variância dos dados espectrais de NIRS explicada para as 10 PCs e erros de calibração e validação da PCA

\begin{tabular}{cccccc}
\hline & Variância & Percentual & \% Cumulativo & Press Val & Press Cal \\
\hline Fator 1 & 0,00495 & 42.13 & 42,13 & 0,0070 & 0,0068 \\
Fator 2 & 0,00352 & 29,97 & 72,10 & 0,0034 & 0,0033 \\
Fator 3 & 0,00092 & 7,81 & 79,91 & 0,0025 & 0,0024 \\
Fator 4 & 0,00059 & 5,00 & 84,91 & 0,0019 & 0,0018 \\
Fator 5 & 0,00022 & 1,87 & 86,78 & 0,0017 & 0,0016 \\
Fator 6 & 0,00008 & 0,68 & 87,46 & 0,0017 & 0,0015 \\
Fator 7 & 0,00006 & 0,47 & 87,94 & 0,0016 & 0,0014 \\
Fator 8 & 0,00005 & 0,41 & 88,35 & 0,0016 & 0,0014 \\
Fator 9 & 0,00005 & 0,38 & 88,73 & 0,0016 & 0,0013 \\
Fator 10 & 0.00004 & 0,35 & 89,08 & 0.0016 & 0,0013 \\
\hline
\end{tabular}

A seguir são apresentados os gráficos de scores e loadings, através dos quais é possível visualizar a distribuição das amostras, com base em suas propriedades mensuradas e outras características inerentes, e correlacionar os agrupamentos com cada variável medida.

Observa-se na Figura 25A, que a espectroscopia NIRS diferencia os solos provenientes das duas localidades provavelmente devido à origem e mineralogia detectada nos espectros, confirmando a hipótese mencionada no item 5.2 após visualização dos espectros de solos cultivados.

Quanto ao uso do solo (Figura 25 B), houve uma segregação entre solos sob cultivo, matas nativas e ciliares, dentro de cada grupo formado pela localidade. Os solos sob integração lavoura-pecuária de Santo Antônio de Goiás (CNPAF) também se agruparam. As pastagens de ambos os locais se dispersaram mais, demonstrando heterogeneidade. Neste grupo foram incluídas áreas com diferentes gramíneas, o que parcialmente justifica esta dispersão. Com relação às amostras de matas nativas, aquelas coletadas em Santo Antônio se mostraram bem homogêneas, pois são originárias de uma mesma mata. Já aquelas coletadas em São Carlos (CPPSE) são originárias de três áreas de preservação em estágios diferentes de recuperação da vegetação natural e densidade de espécies arbóreas, sendo uma delas pouco amostrada (uma amostra de corredor ecológico). 
A textura dos solos está de certa forma relacionada com o local de coleta e o uso do solo (Figura 25 A, B e C). De acordo com as características de fertilidade e textura, entre outras, o solo é indicado para o cultivo, pastagens ou preservação, entre outros usos. Esta relação não é identificada nos gráficos de scores. Observa-se, aliás, que a maioria dos solos de matas nativas e ciliares do CNPAF são muito argilosos enquanto que os solos de mata do CPPSE são franco argila arenosos, não sendo a textura determinante para a escolha do uso do solo.

Em geral, os solos da Embrapa Arroz e Feijão são de textura argilosa enquanto que os solos da Embrapa Pecuária Sudeste são mais diversificados e com maiores teores de areia.
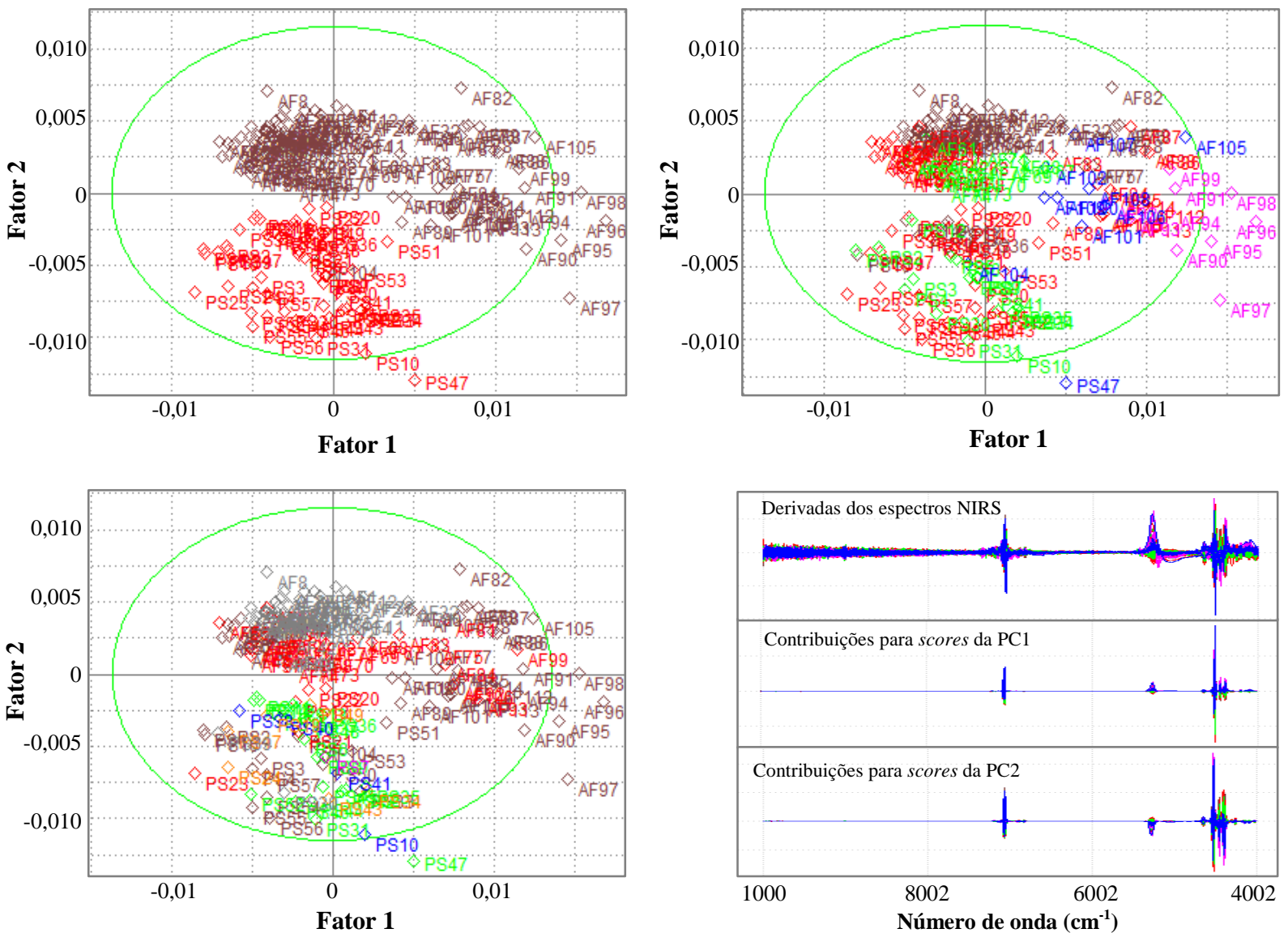

Figura 25 Gráficos de scores (A, B e C) e de loadings (D), Fator 1 versus Fator 2 resultantes de PCAs com espectros NIRS centrados na média. Classes ativadas: (A) Localidade - marrom Santo Antônio de Goiás e vermelho São Carlos; (B) Uso do solo - marrom culturas, verde matas, vermelho pastagens, azul matas ciliares e rosa integração lavourapecuária e (C) Textura - cinza, solos de textura não determinada, marrom solos argilosos, vermelho muito argilosos, verde franco argila arenosos, rosa franco argiloso, azul franco arenosos, laranja argilo arenosos, cinza claro areia franca. (D) Espectros transformados e contribuições de cada região espectral para os scores da PC1 e da PC2. 
Demattê et al. (2005), partindo dos solos mais arenosos para os mais argilosos, perceberam uma diferenciação nas angularidades e nas formas das curvas espectrais em VISNIRS, permitindo discriminalidade entre elas. Isto não foi observado no grupo de amostras coletados, onde a textura por si só não foi capaz de explicar as semelhanças e diferenças espectrais entre esses solos.

A Figura 25 D exibe, além dos gráficos de scores, os espectros transformados e as regiões mais informativas, ou seja, as regiões onde os espectros se diferenciam e resultam em agrupamentos e dispersões. Pode-se constatar que se trata das bandas de absorção e que o sinal intenso em $5186 \mathrm{~cm}^{-1}$ apresentado na Figura 16 contribui pouco para os scores das duas primeiras PCs, que explicam mais de $70 \%$ da variância, não se tratando de região muito informativa.

\subsubsection{Espectroscopia no infravermelho médio}

A análise de componentes principais dos dados espectrais obtidos por DRIFTS também foi realizada, após calcular a $1^{\mathrm{a}}$ derivada com 5 pontos e centrar os dados de absorbância na média. Foram calculadas 10 PCs, sendo escolhidas apenas três (Figura 26 e Tabela 11) para visualizar os scores e loadings.
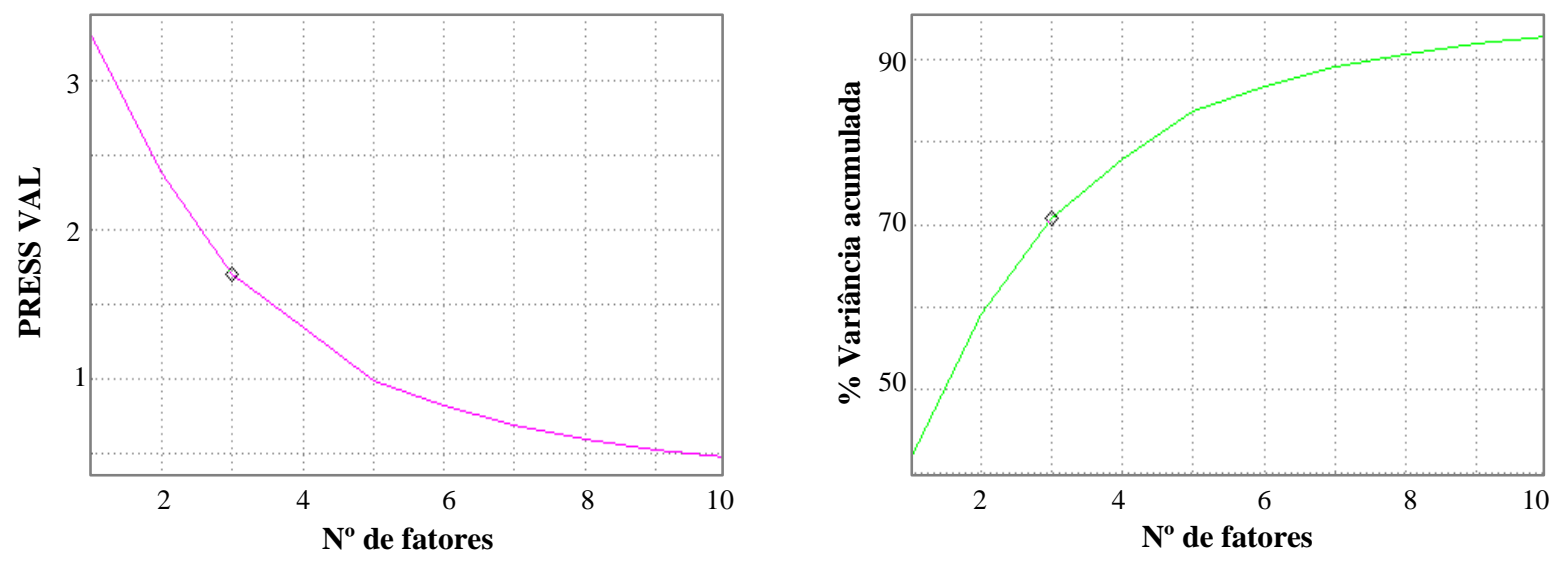

Figura 26 Gráficos de PRESS VAL e \% Variância acumulada versus número de fatores incluídos na PCA DRIFTS. 
Com três fatores obteve-se um percentual de variância total de 70,87\% e um PRESS VAL de 1,71 .

Tabela 11 Variância dos dados espectrais de DRIFTS explicada pelas 10 PCs e erros de calibração e validação da PCA

\begin{tabular}{cccccc}
\hline & Variância & Percentual & \% Cumulativo & Press Val & Press Cal \\
\hline Fator 1 & 2,27 & 41,61 & 41,61 & 3,30 & 3,19 \\
Fator 2 & 0,96 & 17,61 & 59,22 & 2,38 & 2,23 \\
Fator 3 & 0,64 & 11,65 & 70,87 & 1,71 & 1,59 \\
Fator 4 & 0,38 & 6,95 & 77,83 & 1,35 & 1,21 \\
Fator 5 & 0,32 & 5,91 & 83,74 & 0,99 & 0,89 \\
Fator 6 & 0,16 & 2,98 & 86,71 & 0,83 & 0,72 \\
Fator 7 & 0,12 & 2,31 & 89,03 & 0,69 & 0,60 \\
Fator 8 & 0,09 & 1,64 & 90,67 & 0,60 & 0,51 \\
Fator 9 & 0,07 & 1,23 & 91,90 & 0,53 & 0,44 \\
Fator 10 & 0,05 & 0,92 & 92,81 & 0,48 & 0,39 \\
\hline
\end{tabular}

A espectroscopia no infravermelho médio também diferencia as amostras de São Carlos e Santo Antônio de Goiás, como pode ser observado na Figura 27A, porém com menor poder de discriminação que NIRS.

Observa-se na Figura 27B que as amostras de mata nativa e pastagem se encontram bem dispersas e os grupos de solos sob cultivo e integração estão mais definidos. O maior espalhamento das amostras de mata e pastagem pode indicar uma maior sensibilidade de DRIFTS comparada à NIRS com relação aos teores de matéria orgânica e biomassa microbiana.

Do ponto de vista da textura (Figura 27C), os espectros DRIFTS das amostras da Embrapa Pecuária Sudeste se encontram mais dispersas, refletindo a diversidade de composição de partículas de areia, silte e argila, enquanto que os solos da Embrapa Arroz e Feijão contêm maiores teores de argila, sendo possível distinguir as classes de textura argilosa e muito argilosa nesta localidade. Aparentemente, solos de textura semelhantes têm outras propriedades que os diferenciam dentro de uma escala de valores. 
Na Figura 27D visualiza-se a contribuição das bandas de absorção nos scores da PC1 e da PC2. A região da matéria orgânica, de $3200 \mathrm{~cm}^{-1}$ a $2100 \mathrm{~cm}^{-1}$ e de $1750 \mathrm{~cm}^{-1}$ a $1150 \mathrm{~cm}^{-1}$, praticamente só contribui para a PC1.
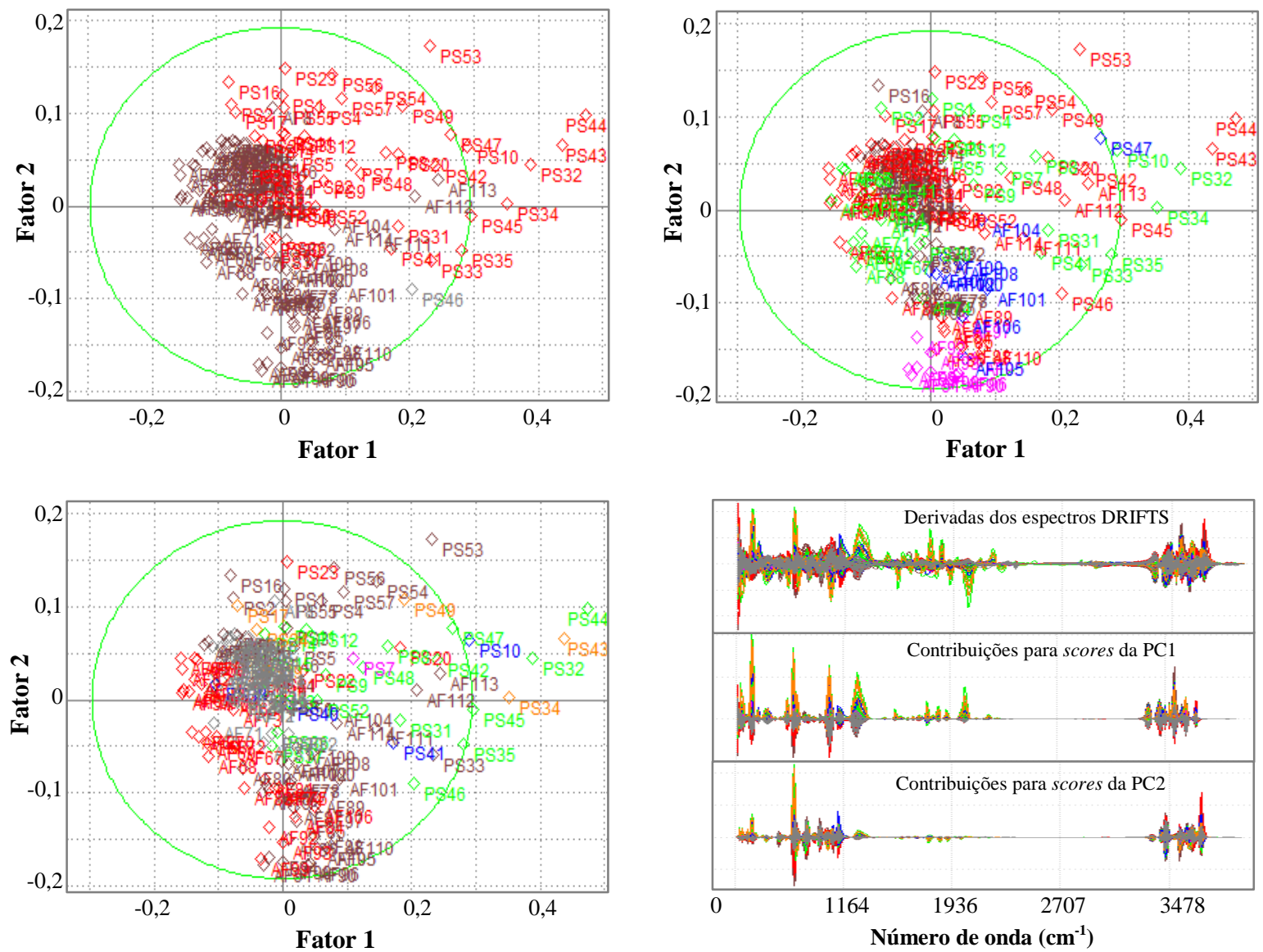

Figura 27 Gráficos de scores (A, B e C) e de loadings (D), Fator 1 versus Fator 2 resultantes de PCAs com espectros DRIFTS centrados na média. Classes ativadas: (A) Localidade - marrom Santo Antônio de Goiás e vermelho São Carlos; (B) Uso do solo - marrom culturas, verde matas, vermelho pastagens, azul matas ciliares e rosa integração lavoura-pecuária e (C) Textura - cinza, solos de textura não determinada, marrom solos argilosos, vermelho muito argilosos, verde franco argila arenosos, rosa franco argiloso, azul franco arenosos, laranja argilo arenosos, cinza claro areia franca. (D) Espectros transformados e contribuições de cada região espectral para os scores da PC1 e da PC2.

\subsection{Textura}

A PCA com os valores de argila, silte e areia, obtidos por procedimentos de referência, foi calculada com três fatores sendo necessárias somente duas PCs para alcançar $100 \%$ da variância e valor zero para PRESS VAL (Figura 28 e Tabela12). 
Tabela 12 Variância dos dados de textura explicada pelas 3 PCs e erros de calibração e validação da PCA

\begin{tabular}{lccccc}
\hline & Variância & Percentual & \% Cumulativo & Press Val & Press Cal \\
\hline Fator1 & 273.315582 & 75.920998 & 75.920998 & 93.943459 & 86.684418 \\
Fator2 & 86.684402 & 24.079002 & 100.000000 & 0.000000 & 0.000000 \\
Fator3 & 0.000000 & 0.000000 & 100.000000 & 0.001160 & 0.000000 \\
\hline
\end{tabular}
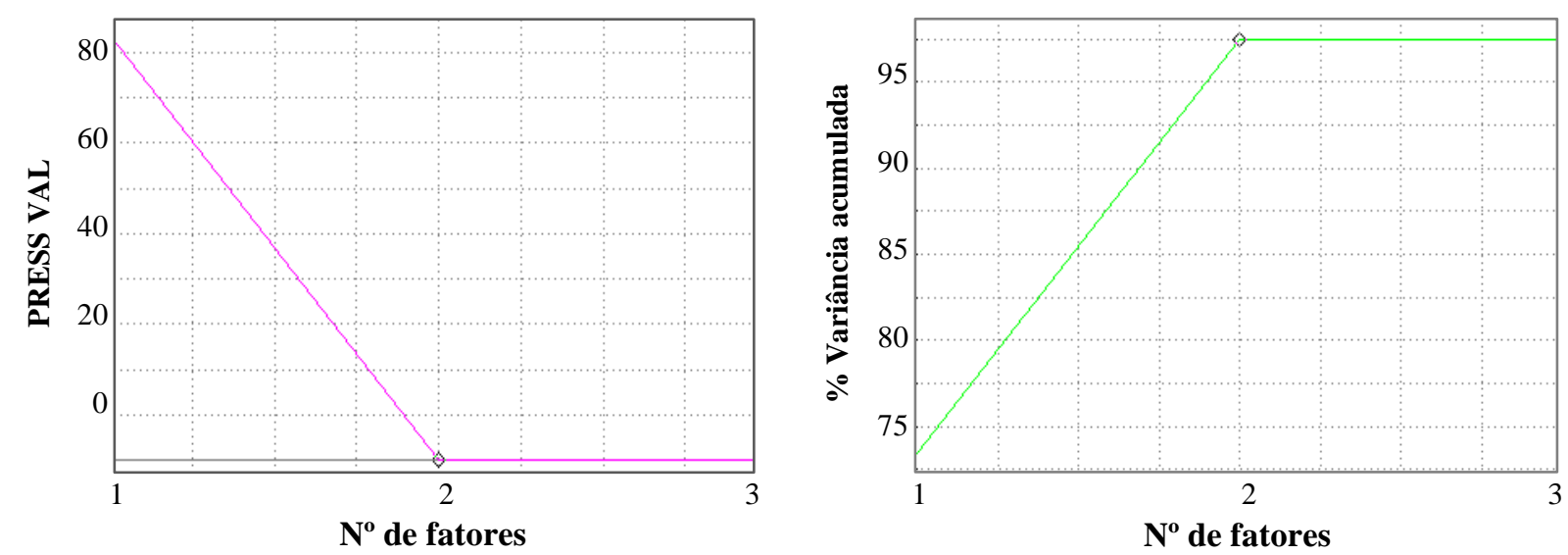

Figura 28 Gráficos de PRESS VAL e \% de variância acumulada versus número de fatores incluídos na PCA Textura.

A textura se mostrou capaz de distinguir entre os solos da Fazenda Canchin (CPPSE) e os solos da Fazenda Capivara (CNPAF) (Figura 29A). Como mencionado anteriormente, o grupo CNPAF possui 2 tipos de textura: argilosa e muito argilosa (Figura 29C). A maioria dos solos do CPPSE tem textura franco argilo arenosa, informação confirmada pelos gráficos de score e loadings (Figura 29C,D) onde a areia está do lado correspondente às amostras PS.

Alguns solos do CNPAF têm quantidade considerável de silte, característica de solos menos intemperizados (DEMATTÊ et al., 2005). Esses solos, cujo uso é a integração lavourapecuária, demonstram alto poder de agregação e compactação ao manuseá-los.

Através da Figura 29B, observa-se que os solos de mata da Embrapa Arroz e Feijão contêm mais argila que aqueles sob pastagem neste local. A Tabela 3, apresentada anteriormente, confirma essa observação. Poucos solos cultivados foram analisados quanto à textura (somente aqueles provenientes da Embrapa Pecuária Sudeste), não sendo possível inferir algo sobre essa classe de uso do solo através destes gráficos. 

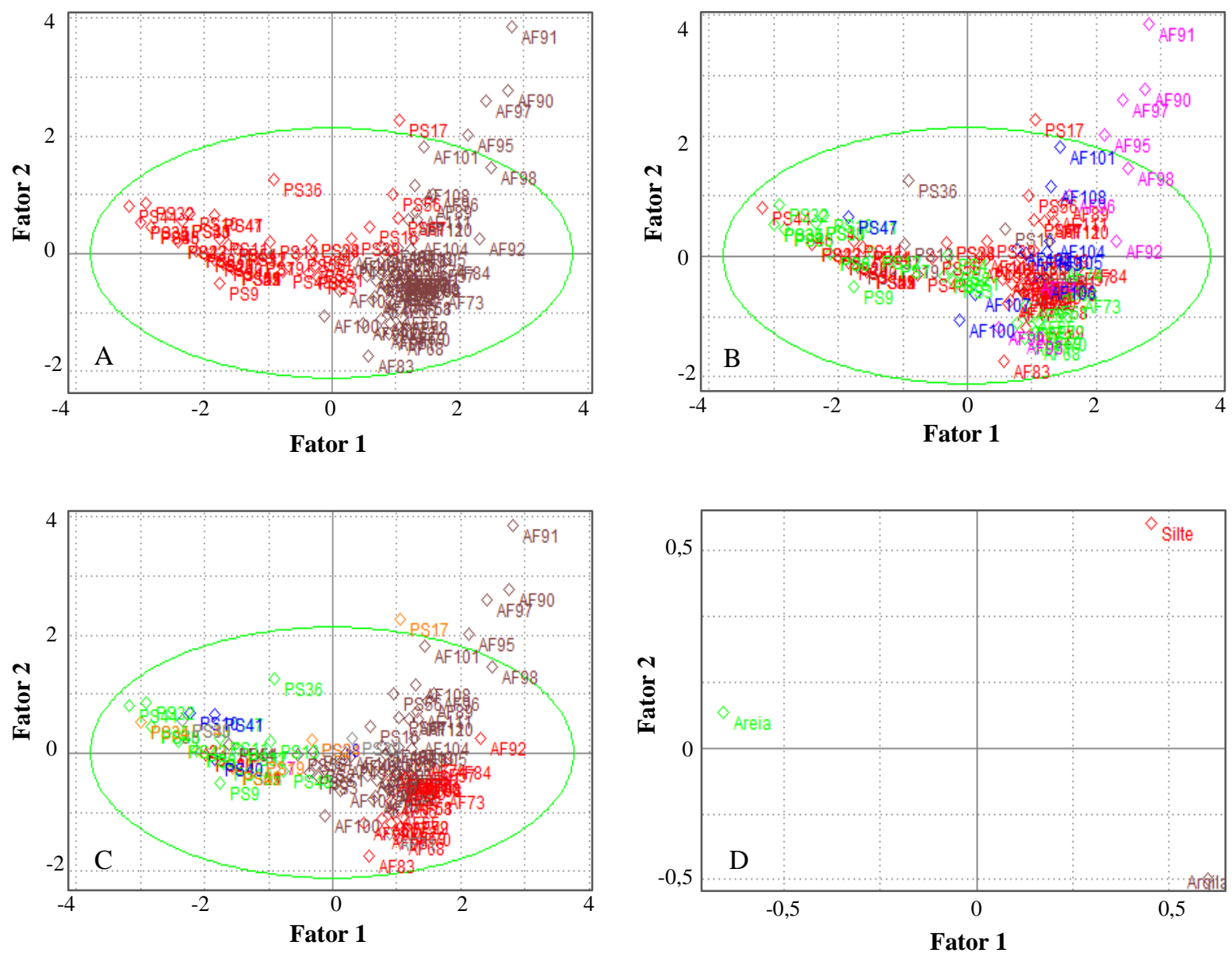

Figura 29 Gráficos de scores e de loadings, Fator 1 versus Fator 2 resultantes de PCAs com dados auto-escalados de argila, silte e areia. Classes ativadas: (A) Localidade - cinza Santo Antônio de Goiás e vermelho São Carlos; (B) Uso do solo - cinza culturas, verde matas, vermelho pastagens, azul matas ciliares e rosa integração lavoura-pecuária e (C) Textura - cinza, solos de textura não determinada, roxo solos argilosos, vermelho muito argilosos, verde franco argila arenosos, rosa franco argiloso, azul franco arenosos, laranja argilo arenosos, cinza claro areia franca.

De acordo com a Figura 30, a quantificação do silte tem o maior poder de modelagem e o menor resíduo. Observando-se, porém, a escala de valores do gráfico verifica-se que, não só o silte, mas também a argila e a areia contribuíram bastante na discriminação dos grupos de amostras. Os resíduos associados são extremamente baixos, mostrando que as duas primeiras PCs são eficientes na reconstrução da matriz de valores. Isso mostra que tais propriedades podem ser facilmente preditas neste universo de amostras. 

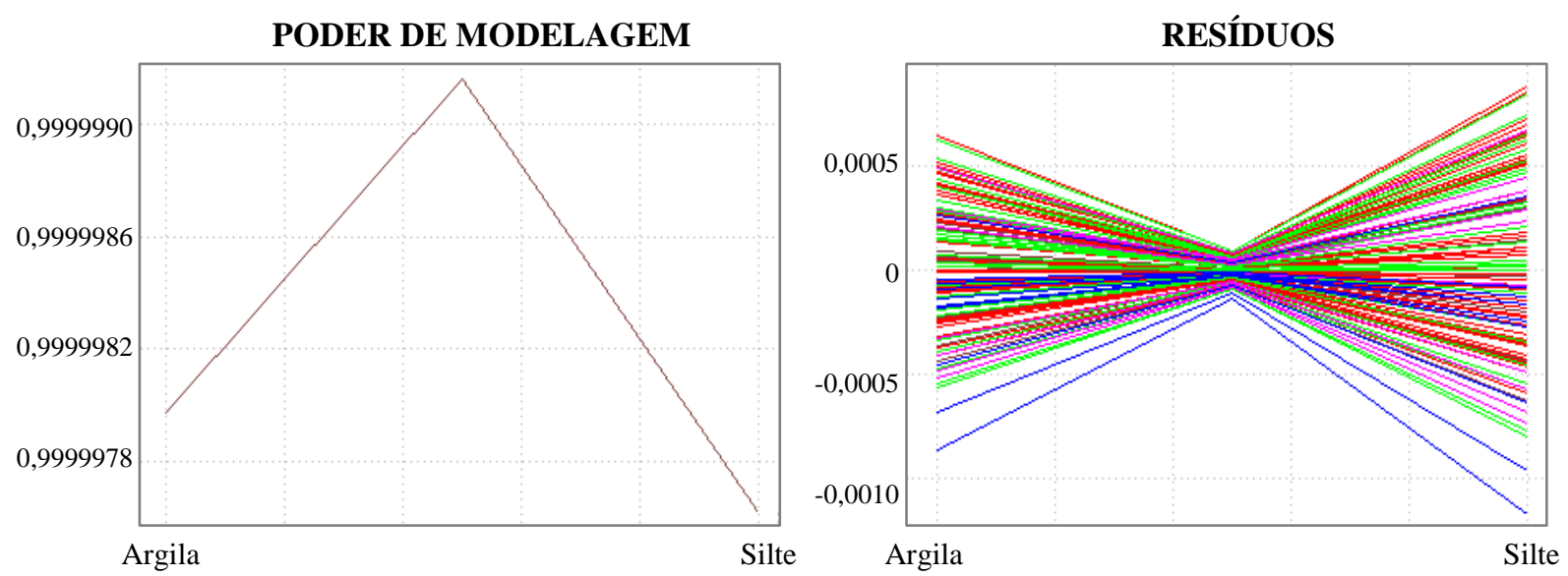

Figura 30 Gráficos de poder de modelagem e resíduos para os atributos Argila, Silte e Areia

Os conteúdos de areia silte e argila, assim como outros atributos analisados, foram preditos por NIRS e DRIFTS em 5 diferentes subgrupos amostrais, divididos segundo uso do solo e localidade: CNPAF, CPPSE, MANEJADOS (cultivados + pastagens + integração), MATAS e TODOS. As Figuras 31 e 32 contêm alguns gráficos de valores preditos versus medidos (Y FIT) provenientes da validação cruzada e da validação externa. Os parâmetros para a avaliação da qualidade dos modelos construídos para textura são detalhados nas Tabelas 13 a 15.

Tabela 13 Dados de validação cruzada e externa para os modelos de calibração em NIRS e DRIFTS para Argila

\begin{tabular}{lccccccccc}
\hline \multicolumn{1}{c}{ Modelo } & NC $^{1}$ & $\mathbf{R V C}^{2}$ & $\mathbf{S E V}^{3}$ & $\mathbf{N V}^{4}$ & $\mathbf{N F}^{5}$ & Intecepto & Inclinação & RVE $^{6}$ & Erro (\%) \\
\hline CNPAF NIRS & 55 & 0,3622 & 65,80 & 15 & 4 & 514,20 & 0,13 & 0,1648 & 9,32 \\
CNPAF DRIFTS & 55 & 0,6173 & 45,90 & 15 & 3 & 556,63 & 0,05 & 0,2170 & 13,32 \\
CPPSE NIRS & 40 & 0,7400 & 76,35 & 11 & 1 & 219,28 & 0,36 & 0,6093 & 32,24 \\
CPPSE DRIFTS & 38 & 0,7906 & 75,42 & 12 & 1 & 306,47 & 0,07 & 0,0979 & 20,82 \\
MATAS NIRS & 24 & 0,9641 & 55,10 & 6 & 3 & 178,68 & 0,63 & 0,9367 & 18,26 \\
MATAS DRIFTS & 23 & 0,9733 & 48,56 & 6 & 6 & 257,20 & 0,41 & 0,5261 & 37,90 \\
TODOS NIRS & 100 & 0,8354 & 86,17 & 21 & 3 & 245,97 & 0,47 & 0,7649 & 24,93 \\
TODOS DRIFTS & 96 & 0,9109 & 66,56 & 24 & 5 & 131,37 & 0,65 & 0,7448 & 20,85 \\
MANEJADOS NIRS & 72 & 0,7734 & 88,98 & 19 & 3 & 215,00 & 0,52 & 0,7595 & 17,57 \\
MANEJADOS DRIFTS & 74 & 0,8607 & 73,74 & 17 & 6 & 130,98 & 0,70 & 0,7837 & 16,33 \\
\hline
\end{tabular}

${ }^{1} \mathrm{NC}=$ número de amostras de calibração; ${ }^{2} \mathrm{RVC}=$ coeficiente de regressão obtido pela validação cruzada; ${ }^{3} \mathrm{SEV}=$ erro de validação cruzada (ver Equação 9); ${ }^{4} \mathrm{NV}=$ número de amostras de validação; ${ }^{5} \mathrm{NF}=$ número de fatores ou PCs utilizados no cálculo da PLS; ${ }^{6} \mathrm{RVE}=$ coeficiente de regressão obtido pela validação externa. 
Tabela 14 Dados de validação cruzada e externa para os modelos de calibração em NIRS e DRIFTS para Silte

\begin{tabular}{lccccccccc}
\hline \multicolumn{1}{c}{ Modelo } & NC $^{1}$ & $\mathbf{R V C}^{2}$ & $\mathbf{S E V}^{3}$ & $\mathbf{N V}^{4}$ & $\mathbf{N F}^{5}$ & Intecepto & Inclinação & RVE $^{6}$ & Erro(\%) \\
\hline CNPAF NIRS & 55 & 0,6703 & 52,91 & 15 & 2 & 79,32 & 0,38 & 0,6391 & 119,43 \\
CNPAF DRIFTS & 55 & 0,6873 & 52,02 & 15 & 4 & 101,09 & $-0,13$ & $-0,1459$ & 149,03 \\
CPPSE NIRS & 40 & 0,3496 & 42,60 & 11 & 1 & 63,19 & $-0,08$ & $-0,2620$ & 64,78 \\
CPPSE DRIFTS & 38 & 0,4543 & 40,32 & 12 & 2 & 52,76 & $-0,02$ & $-0,0798$ & 103,28 \\
MATAS NIRS & 24 & 0,4502 & 22,37 & 6 & 2 & 51,86 & 0,17 & 0,4243 & 20,27 \\
MATAS DRIFTS & 23 & 0,2733 & 24,97 & 6 & 4 & 59,18 & $-0,09$ & $-0,2181$ & 138,65 \\
TODOS NIRS & 100 & 0,6295 & 52,26 & 21 & 4 & 31,85 & 0,66 & 0,5348 & 49,13 \\
TODOS DRIFTS & 96 & 0,6045 & 50,05 & 24 & 4 & 18,17 & 0,63 & 0,1590 & 56,19 \\
MANEJADOS NIRS & 72 & 0,6264 & 57,60 & 19 & 4 & 39,76 & 0,54 & 0,5280 & 49,81 \\
MANEJADOS DRIFTS & 74 & 0,5844 & 54,00 & 17 & 4 & 12,97 & 0,59 & 0,8012 & 40,49 \\
\hline
\end{tabular}

${ }^{1} \mathrm{NC}=$ número de amostras de calibração; ${ }^{2} \mathrm{RVC}=$ coeficiente de regressão obtido pela validação cruzada; ${ }^{3} \mathrm{SEV}=$ erro de validação cruzada (ver Equação 9); ${ }^{4} \mathrm{NV}=$ número de amostras de validação; ${ }^{5} \mathrm{NF}=$ número de fatores ou PCs utilizados no cálculo da PLS; ${ }^{6} \mathrm{RVE}=$ coeficiente de regressão obtido pela validação externa.

Tabela 15 Dados de validação cruzada e externa para os modelos de calibração em NIRS e DRIFTS para Areia

\begin{tabular}{lccccccccc}
\hline \multicolumn{1}{c}{ Modelo } & NC $^{1}$ & $\mathbf{R V C}^{2}$ & SEV $^{3}$ & $\mathbf{N V}^{4}$ & $\mathbf{N F}^{5}$ & Intecepto & Inclinação $^{\text {RVE }^{6}}$ & Erro(\%) \\
\hline CNPAF NIRS & 55 & 0,4704 & 64,86 & 15 & 3 & 249,97 & 0,14 & 0,1850 & 17,82 \\
CNPAF DRIFTS & 55 & 0,5776 & 46,50 & 15 & 8 & 257,08 & 0,16 & 0,3109 & 20,81 \\
CPPSE NIRS & 40 & 0,6916 & 104,14 & 11 & 1 & 400,77 & 0,33 & 0,5266 & 13,65 \\
CPPSE DRIFTS & 38 & 0,7966 & 93,02 & 12 & 2 & 564,98 & 0,10 & 0,1321 & 9,35 \\
MATAS NIRS & 24 & 0,9566 & 64,38 & 6 & 4 & 219,25 & 0,50 & 0,9015 & 22,22 \\
MATAS DRIFTS & 23 & 0,9625 & 60,08 & 6 & 5 & 290,50 & 0,64 & 0,6503 & 19,77 \\
TODOS NIRS & 100 & 0,8185 & 108,28 & 21 & 4 & 145,87 & 0,71 & 0,8845 & 23,37 \\
TODOS DRIFTS & 96 & 0,8992 & 82,18 & 24 & 5 & 184,79 & 0,69 & 0,8167 & 18,12 \\
MANEJADOS NIRS & 72 & 0,7604 & 115,06 & 19 & 4 & 148,49 & 0,72 & 0,8450 & 25,81 \\
MANEJADOS DRIFTS & 74 & 0,8616 & 89,10 & 17 & 5 & 174,20 & 0,72 & 0,8795 & 27,03 \\
\hline
\end{tabular}

${ }^{1} \mathrm{NC}=$ número de amostras de calibração; ${ }^{2} \mathrm{RVC}=$ coeficiente de regressão obtido pela validação cruzada; ${ }^{3} \mathrm{SEV}=$ erro de validação cruzada (ver Equação 9); ${ }^{4} \mathrm{NV}=$ número de amostras de validação; ${ }^{5} \mathrm{NF}=$ número de fatores ou PCs utilizados no cálculo da PLS; ${ }^{6} \mathrm{RVE}=$ coeficiente de regressão obtido pela validação externa.

Analisando os parâmetros apresentados, destacam-se os modelos MATAS NIRS na quantificação de argila e areia, apesar do infravermelho próximo não ser capaz de detectar compostos como silicatos, largamente presentes nos solos. Isto pode ser explicado pela sensibilidade de NIRS à distribuição das partículas quanto ao tamanho (MADARI et al., 2005, 2006a; CHANG et al., 2001).

Os modelos MANEJADOS e TODOS construídos com espectros nas duas regiões do infravermelho também trouxeram bons resultados. Dessa forma, a separação das amostras de locais diferentes não demonstrou incremento de eficácia na predição dos componentes 
texturais dos solos, visto que proporcionam uma redução de variabilidade de teores de argila, silte e areia dentro dos grupos amostrais.

Verificou-se que tanto NIRS quanto DRIFTS predisseram satisfatoriamente os teores de areia e argila, diferentemente de Viscarra-Rossel et al. (2006), que observaram melhores resultados com os espectros no infravermelho médio. Os coeficientes de regressão (RVC e RVE) foram superiores aos alcançados por estes autores em DRIFTS (argila $=0,67$; silte $=$ $0,49$ e areia $=0,74)$ e por Chang et al.(2001) em NIRS (argila $=0,67$, silte $=0,84$ e areia $=$ 0,82). Conforme esperado, as calibrações para silte resultaram em predições menos acuradas, em função do método de quantificação indireto desse constituinte.

Os valores preditos para as amostras de validação externa estão detalhados na Tabela 16.

Tabela 16 Valores medidos de referência e preditos pelo modelo MATAS NIRS para Argila, Silte e Areia

\begin{tabular}{ccccccc}
\hline & \multicolumn{2}{c}{ Argila } & \multicolumn{2}{c}{ Silte } & \multicolumn{2}{c}{ Areia } \\
Amostras & Medidos & Preditos & Medidos & Preditos & Medidos & Preditos \\
\hline PS2 & 456,00 & 465,00 & 67,2 & 76,75 & 476,8 & 441,41 \\
PS5 & 456,00 & 420,24 & 57,2 & 56,96 & 486,8 & 555,00 \\
PS12 & 316,00 & 457,01 & 47,2 & 63,73 & 636,8 & 483,53 \\
PS30 & 196,00 & 263,13 & 47,2 & 58,34 & 756,8 & 608,45 \\
AF70 & 678,80 & 593,88 & 47,2 & 54,16 & 274 & 354,69 \\
AF73 & 678,80 & 621,92 & 97,2 & 64,49 & 224 & 310,78 \\
\hline
\end{tabular}

Tendo em vista a pequena diferença de precisão entre os modelos construídos com espectros NIRS e com espectros DRIFTS, talvez a técnica mais indicada fosse NIRS. Isto devido à maior facilidade de manuseio de amostras pulverizadas, além do menor custo do equipamento e da sua manutenção (VISCARRA-ROSSEL et al., 2006).

Somam-se a essas características de NIRS a disponibilidade de equipamentos portáteis para uso em campo (VISCARRA-ROSSEL et al., 2006) e a larga utilização desta faixa do infravermelho na obtenção de dados por satélites (DALMOLIN et al., 2005; FORMAGGIO e EPIPHANIO, 2009). 

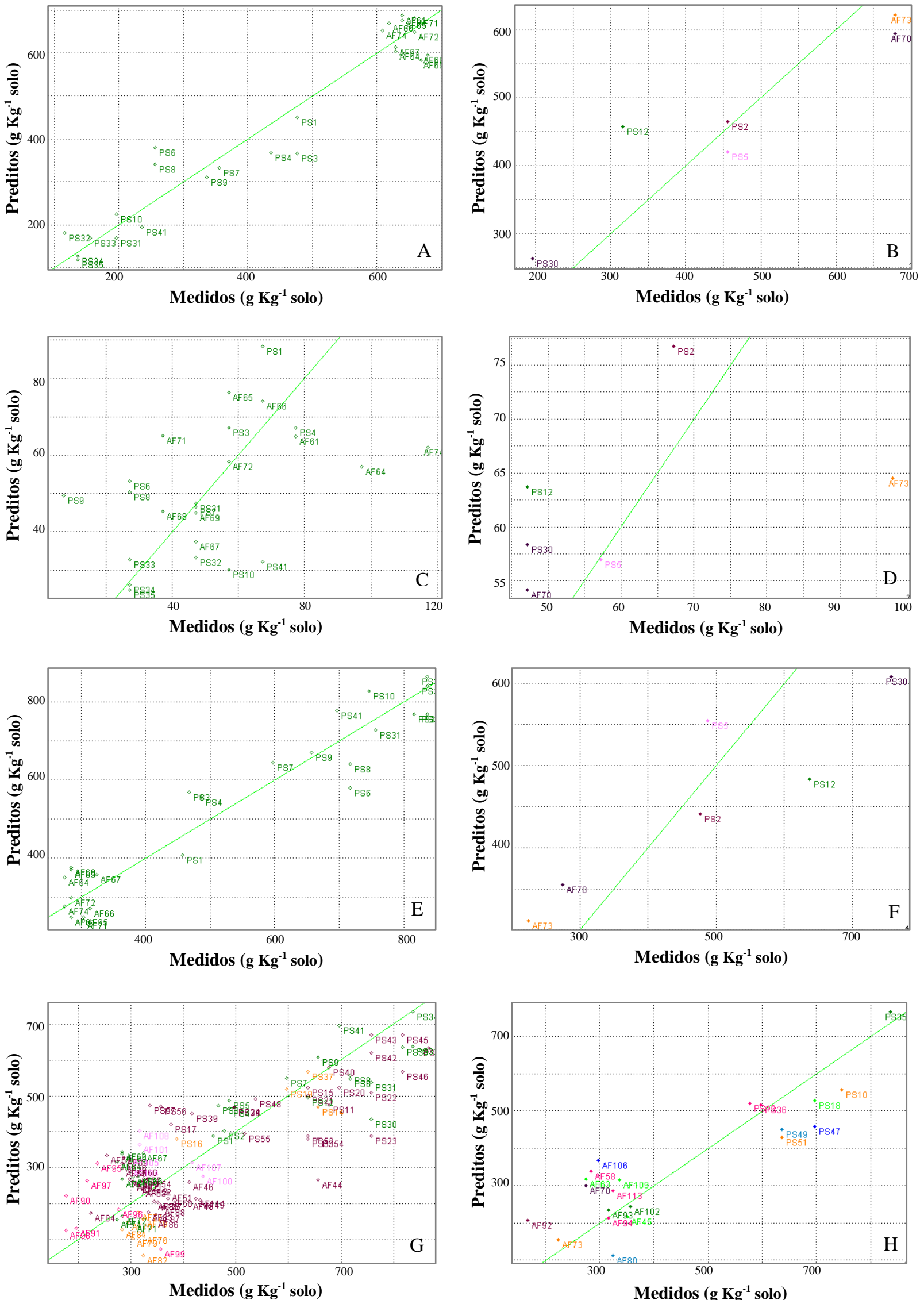

Figura 31 Gráficos dos valores medidos (de referência) versus valores preditos por modelos calculados com dados de NIRS, resultantes da validação cruzada (A, C, E e G) e da validação externa (B, D , F e H). (A) e (B) Argila pelo modelo Matas; (C) e (D) Silte pelo modelo Matas; (E) e (F) Areia pelo modelo Matas; (G) e (H) Areia pelo modelo Todos. As linhas indicam valores 1:1. 

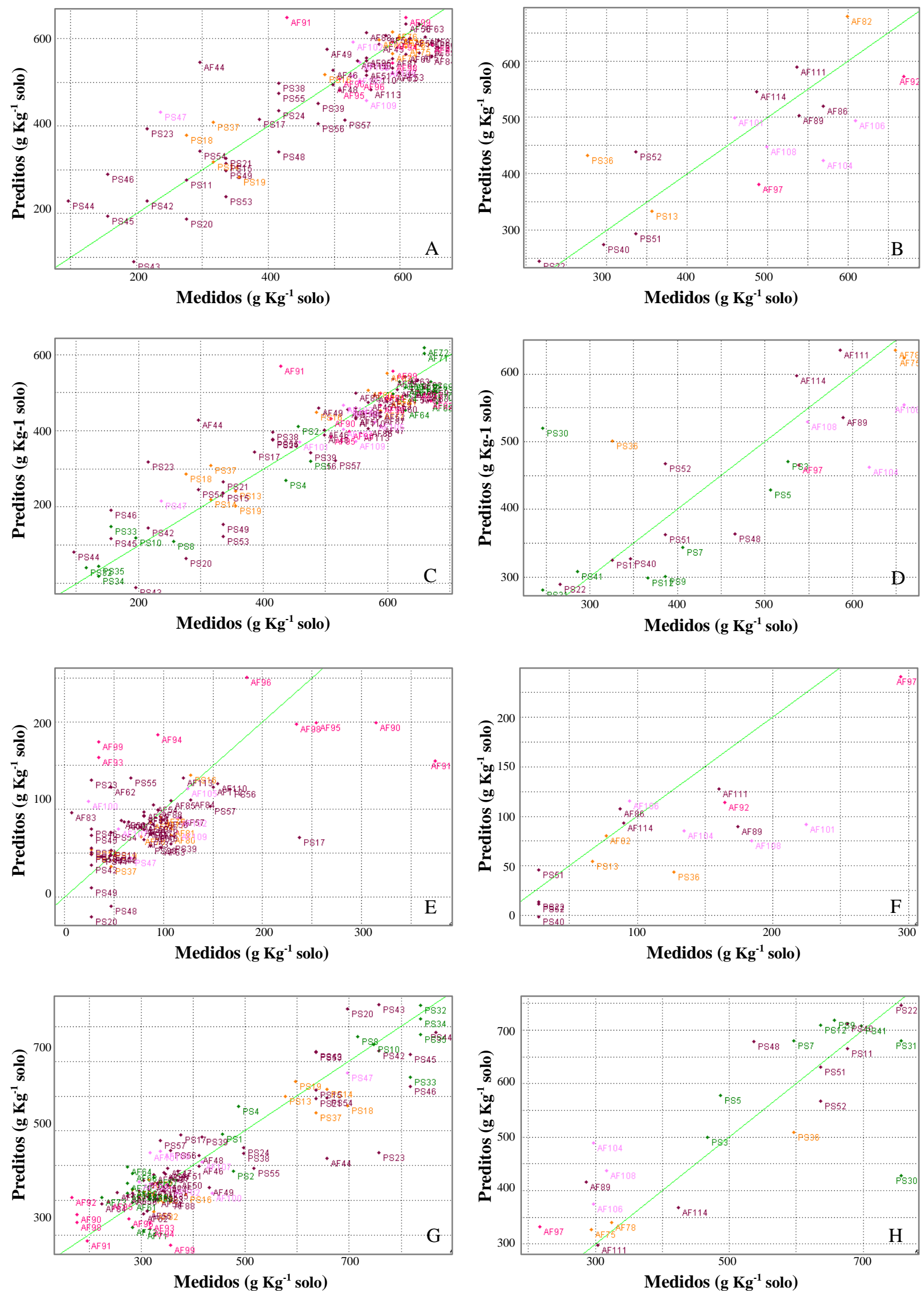

Figura 32 Gráficos dos valores medidos versus valores preditos por modelos calculados com dados de DRIFTS, resultantes da validação cruzada (A, C, E, G) e da validação externa (B, D, F, H). (A) e (B) Argila pelo modelo Manejados; (C) e (D) Argila pelo modelo Todos; (E) e (F) Silte pelo modelo Manejados; $(\mathrm{G})$ e (H) Areia pelo modelo Todos. As linhas indicam valores 1:1. 


\subsection{Matéria orgânica}

No grupo de matéria orgânica foram selecionados três fatores na PCA, totalizando 99,62\% de variância explicada e um Press Val igual a 1,82, conforme dados da Figura 33 e da Tabela 17.
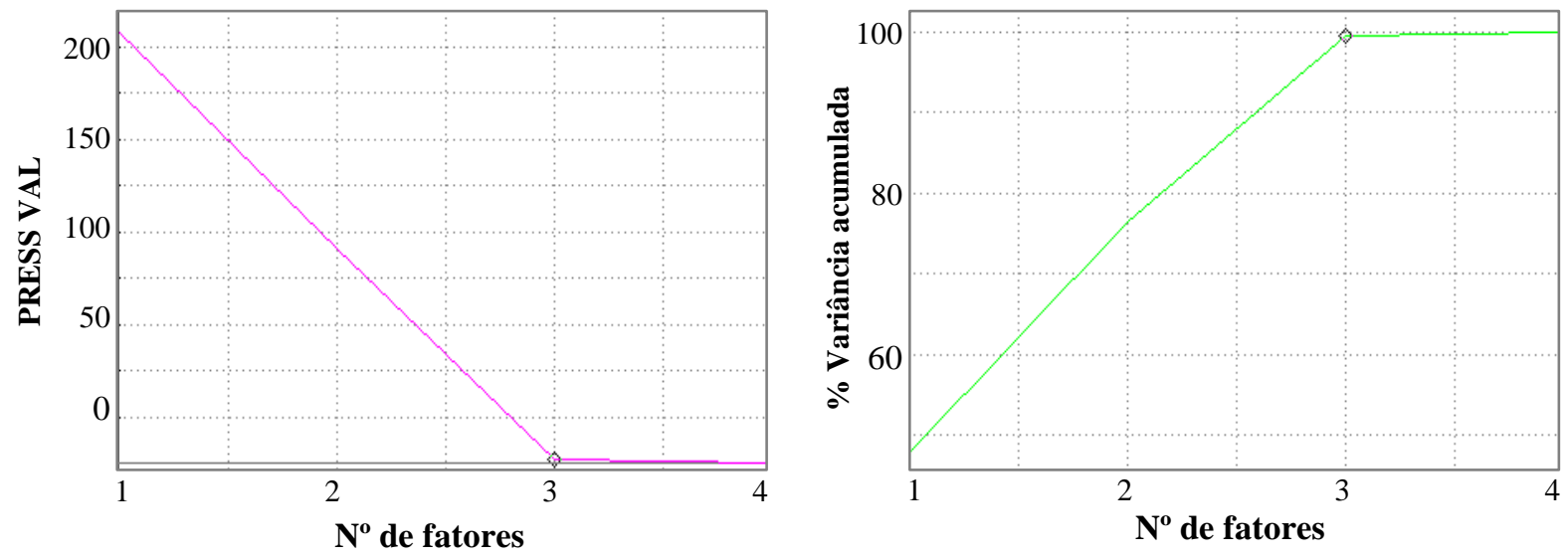

Figura 33 Gráfico de PRESS VAL versus número de fatores incluídos na PCA Matéria orgânica.

Tabela 17 Variância dos dados de matéria orgânica explicada pelas 3 PCs e erros de calibração e validação da PCA

\begin{tabular}{lccccc}
\hline & Variância & Percentual & \% Cumulativo & Press Val & Press Cal \\
\hline Fator 1 & 189,28 & 47,79 & 47,80 & 232,55 & 206,72 \\
Fator 2 & 113,23 & 28,59 & 76,39 & 115,56 & 93,48 \\
Fator 3 & 91,99 & 23,23 & 99,62 & 1,82 & 1,49 \\
Fator 4 & 1,49 & 0,38 & 100,00 & 0,00 & 0,00 \\
\hline
\end{tabular}

Observa-se na Figura 34B que as amostras de matas nativas e algumas provenientes de mata ciliar se destacam pela grande quantidade de carbono total e que amostras e sob integração possuem alto teores de nitrogênio. Os solos de mata da Embrapa Pecuária Sudeste se mostraram menos ricos em carbono, com menor relação $\mathrm{C} / \mathrm{N}$ que os solos de mata da Embrapa Arroz e Feijão.

Diversos solos sob pastagens demonstraram uma alta relação C/N (Figura 34B,D), característico de gramíneas, destacando-se os solos CNPAF de textura muito argilosa, o que era esperado devido à sua capacidade de armazenar carbono pela proteção física exercida por 
agregados presentes nesses solos. A maioria dos solos apresentou valores intermediários de COT.
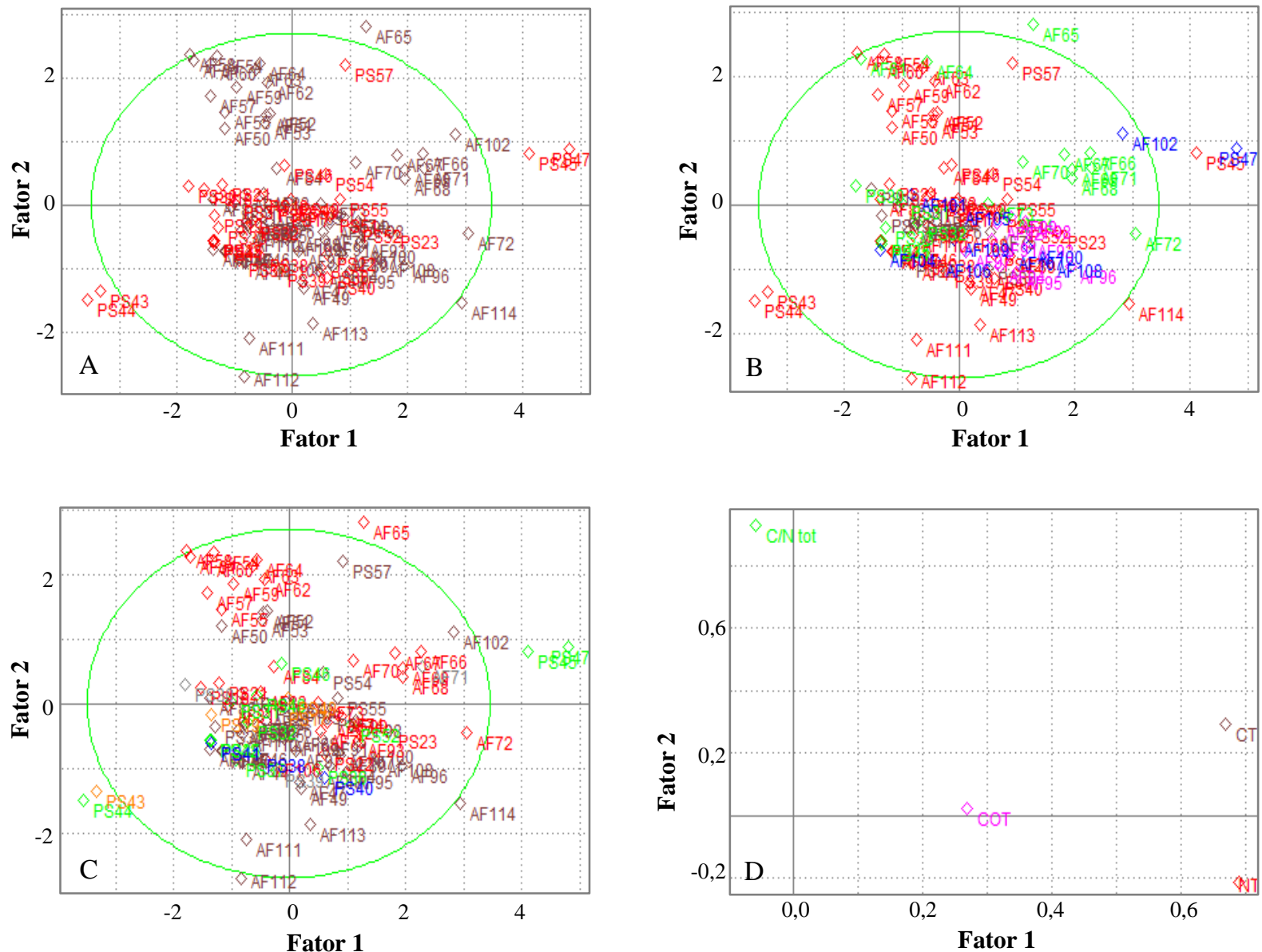

Figura 34 Gráficos de scores (A, B e C) e de loadings (D), Fator 1 versus Fator 2 resultantes de PCAs com dados auto-escalados de carbono orgânico, carbono total, nitrogênio total e razão C/N.Classes ativadas: (A) Localidade - cinza Santo Antônio de Goiás e vermelho São Carlos; (B) Uso do solo - cinza culturas, verde matas, vermelho pastagens, azul matas ciliares e rosa integração lavoura-pecuária; (C) Textura - cinza solos de textura não determinada, roxo solos argilosos, vermelho muito argilosos, verde franco argila arenosos, rosa franco argiloso, azul franco arenosos, laranja argilo arenosos, cinza claro areia franca.
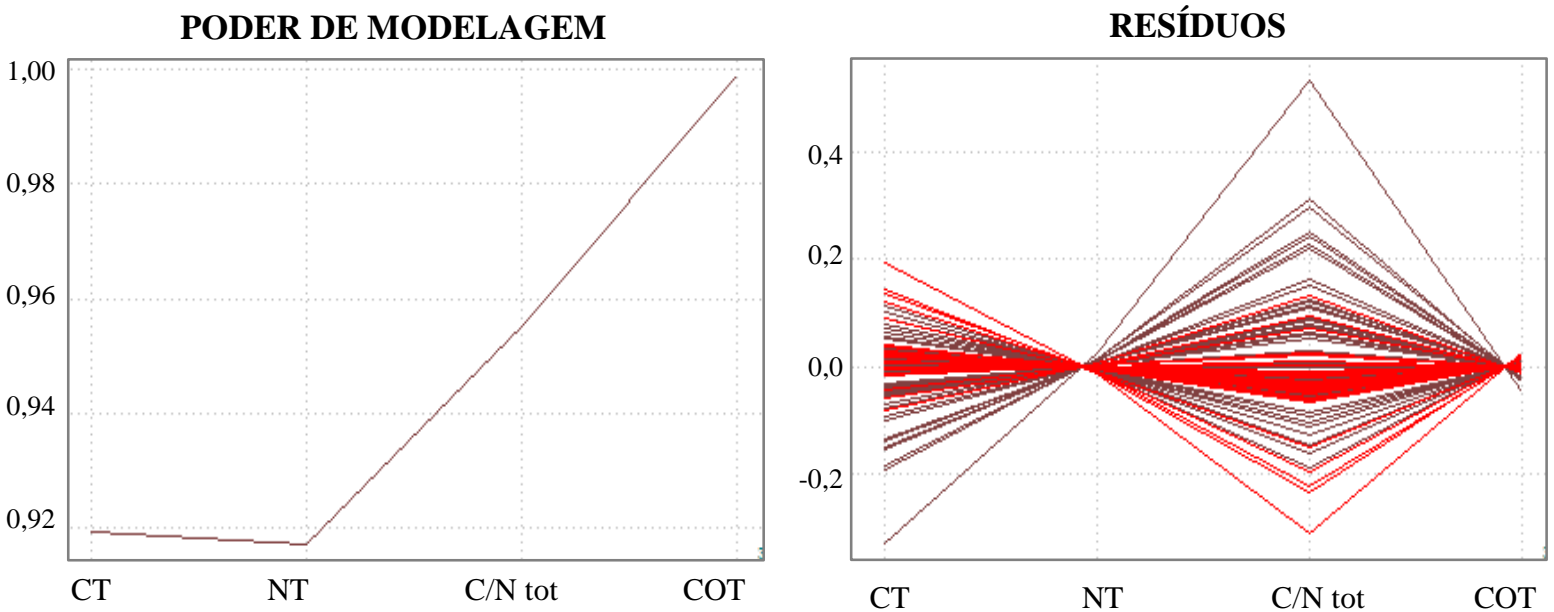

Figura 35 Gráficos apresentando poder de modelagem e resíduos associados a cada atributo componente do carbono orgânico e da análise elementar. 
No gráfico de loadings (Figura 34D) constata-se também a correlação entre as variáveis CT, NT e COT, pela proximidade entre elas.

Através dos gráficos de poder de modelagem e resíduos (Figura 35) verifica-se que o nitrogênio total e o carbono orgânico são propriedades com alto poder de modelagem associado a baixos resíduos, resultando em situação ideal para o seu uso em calibrações. Na verdade, todos esses atributos constituintes da matéria orgânica apresentaram alto poder de modelagem.

Os parâmetros para a avaliação da qualidade desses modelos de predição são detalhados nas Tabelas 18 a 21 e os teores de COT, CT, NT e C/N total, preditos por NIRS e DRIFTS, são apresentados na Tabela 22, e, graficamente, nas Figuras 36 e 37.

Tabela 18 Dados de validação cruzada e externa para os modelos de calibração em NIRS e DRIFTS para COT

\begin{tabular}{|c|c|c|c|c|c|c|c|c|c|}
\hline Modelo & $\mathbf{N C}^{1}$ & $\mathbf{R V C}^{1}$ & $\mathbf{S E V}^{2}$ & $\mathbf{N V}^{4}$ & $\mathbf{N F}^{3}$ & Intecepto & Inclinação & $\mathbf{R V E}^{4}$ & $\operatorname{Erro}(\%)$ \\
\hline CNPAF NIRS & 89 & 0,5425 & 7,30 & 23 & 4 & 16,02 & 0,42 & 0,6506 & 14,61 \\
\hline CNPAF DRIFTS & 84 & 0,6735 & 6,09 & 25 & 4 & 13,99 & 0,53 & 0,8352 & 13,82 \\
\hline CPPSE NIRS & 40 & 0,3412 & 10,68 & 10 & 4 & 20,32 & 0,27 & 0,6286 & 17,95 \\
\hline CPPSE DRIFTS & 39 & 0,5905 & 9,48 & 11 & 4 & 34,94 & $-0,05$ & $-0,1237$ & 26,12 \\
\hline MATAS NIRS & 18 & 0,5936 & 8,16 & 15 & 3 & 20,83 & 0,50 & 0,6718 & 21,84 \\
\hline MATAS DRIFTS & 25 & 0,7325 & 6,54 & 7 & 6 & 29,48 & 0,24 & 0,5031 & 25,34 \\
\hline TODOS NIRS & 129 & 0,3635 & 8,48 & 32 & 5 & 15,37 & 0,41 & 0,7398 & 22,47 \\
\hline TODOS DRIFTS & 126 & 0,6318 & 6,80 & 33 & 4 & 25,08 & 0,18 & 0,3278 & 20,04 \\
\hline MANEJADOS NIRS & 102 & 0,5729 & 5,73 & 26 & 4 & 17,59 & 0,22 & 0,3592 & 23,08 \\
\hline MANEJADOS DRIFTS & 101 & 0,6948 & 5,58 & 27 & 3 & 2,07 & 0,24 & 0,4047 & 17,43 \\
\hline
\end{tabular}

A melhor predição para COT foi realizada pelo modelo CNPAF DRIFTS, local que apresentou dois agrupamentos na PCA com dados de matéria orgânica, combinando o menor erro percentual com maiores coeficientes de regressão (RVC e RVE). Esse também foi melhor modelo para CT, confirmando a correlação entre esses dados (Tabela 19). 
Tabela 19 Dados de validação cruzada e externa para os aos modelos de calibração em NIRS e DRIFTS para CT

\begin{tabular}{lccccccccc}
\hline \multicolumn{1}{c}{ Modelo } & NC $^{1}$ & RVC $^{2}$ & SEV $^{3}$ & $\mathbf{N V}^{4}$ & $\mathbf{N F}^{5}$ & Intecepto $^{\text {Inclinação }}$ & RVE $^{6}$ & Erro (\%) $^{\text {(\% }}$ \\
\hline CNPAF NIRS & 55 & 0,4102 & 0,62 & 15 & 5 & 2,79 & 0,01 & 0,0385 & 18,95 \\
CNPAF DRIFTS & 56 & 0,5503 & 0,60 & 14 & 5 & 2,59 & 0,16 & 0,3052 & 23,02 \\
CPPSE NIRS & 26 & 0,0838 & 4,23 & 7 & 8 & $-1,90$ & 2,33 & 0,6266 & 65,89 \\
CPPSE DRIFTS & 39 & $-0,0021$ & 3,05 & 10 & 1 & 2,07 & 0,22 & 0,5566 & 46,27 \\
MATAS NIRS & 15 & $-0,2755$ & 5,18 & 4 & 2 & 8,29 & $-1,24$ & $-0,6116$ & 92,66 \\
MATAS DRIFTS & 23 & 0,0328 & 4,06 & 6 & 2 & 1,74 & 0,29 & 0,4036 & 42,40 \\
TODOS NIRS & 82 & $-0,1517$ & 2,09 & 21 & 1 & 3,33 & $-0,11$ & $-0,3182$ & 22,63 \\
TODOS DRIFTS & 95 & $-0,0396$ & 2,15 & 24 & 3 & 2,32 & 0,14 & $-0,1443$ & 35,83 \\
MANEJADOS NIRS & 67 & 0,0794 & 59,49 & 17 & 6 & 3,33 & $-0,21$ & $-0,3772$ & 34,01 \\
MANEJADOS DRIFTS & 72 & $-0,1300$ & 0,87 & 18 & 2 & 2,73 & 0,05 & 0,2049 & 33,48 \\
\hline
\end{tabular}

${ }^{1} \mathrm{NC}=$ número de amostras de calibração; ${ }^{2} \mathrm{RVC}=$ coeficiente de regressão obtido pela validação cruzada; ${ }^{3} \mathrm{SEV}=$ erro de validação cruzada (ver Equação 9); ${ }^{4} \mathrm{NV}=$ número de amostras de validação; ${ }^{5} \mathrm{NF}=$ número de fatores ou PCs utilizados no cálculo da PLS; ${ }^{6} \mathrm{RVE}=$ coeficiente de regressão obtido pela validação externa.

Tabela 20 Dados de validação cruzada e externa para os aos modelos de calibração em NIRS e DRIFTS para NT

\begin{tabular}{lccccccccc}
\hline \multicolumn{1}{c}{ Modelo } & NC $^{1}$ & $\mathbf{R V C}^{2}$ & $\mathbf{S E V}^{3}$ & $\mathbf{N V}^{4}$ & $\mathbf{N F}^{5}$ & Intecepto $^{\text {Inclinação }}$ & RVE $^{6}$ & Erro (\%) $^{\text {M }}$ \\
\hline CNPAF NIRS & 55 & 0,2136 & 0,66 & 15 & 4 & 0,23 & $-0,08$ & $-0,1836$ & 20,74 \\
CNPAF DRIFTS & 56 & 0,4773 & 0,06 & 14 & 3 & 0,25 & $-0,09$ & $-0,1623$ & 27,82 \\
CPPSE NIRS & 26 & $-0,0052$ & 0,59 & 7 & 4 & 0,25 & 0,13 & 0,0445 & 65,89 \\
CPPSE DRIFTS & 39 & $-0,087$ & 0,69 & 10 & 1 & 0,60 & 0,03 & 0,3407 & 146,99 \\
MATAS NIRS & 15 & $-0,1365$ & 0,98 & 4 & 10 & 2,92 & $-11,91$ & $-0,9346$ & 216,39 \\
MATAS DRIFTS & 23 & 0,3124 & 0,70 & 6 & 2 & 0,70 & 0,16 & 0,5710 & 216,95 \\
TODOS NIRS & 82 & $-0,0065$ & 0,29 & 21 & 1 & 0,21 & 0,11 & 0,1658 & 21,74 \\
TODOS DRIFTS & 95 & 0,1572 & 0,42 & 24 & 1 & 0,30 & 0,05 & 0,4962 & 73,52 \\
MANEJADOS NIRS & 67 & 0,4391 & 0,06 & 17 & 3 & 0,24 & $-0,14$ & $-0,2322$ & 31,10 \\
MANEJADOS DRIFTS & 72 & 0,1819 & 0,29 & 18 & 1 & 0,23 & 0,11 & 0,2976 & 43,39 \\
\hline
\end{tabular}

${ }^{1} \mathrm{NC}=$ número de amostras de calibração; ${ }^{2} \mathrm{RVC}=$ coeficiente de regressão obtido pela validação cruzada; ${ }^{3} \mathrm{SEV}=$ erro de validação cruzada (ver Equação 9); ${ }^{4} \mathrm{NV}=$ número de amostras de validação; ${ }^{5} \mathrm{NF}=$ número de fatores ou PCs utilizados no cálculo da PLS; ${ }^{6} \mathrm{RVE}=$ coeficiente de regressão obtido pela validação externa.

Esperava-se que os resíduos de validação fossem baixos na predição de constituintes quantificados pela análise elementar, visto que essa é uma técnica precisa e confiável e que a acurácia das quantificações pela calibração multivariada de espectros depende da precisão do método de referência. Tais calibrações não alcançaram a qualidade dos modelos obtidos por Vergnoux et al. (2009) em NIRS, com $r^{2}$ iguais a 0,97 e 0,97, Madari et al. (2006a) em DRIFTS, com $r^{2}$ iguais a 0,97 e 0,97, Ludwig et al. (2002) em NIRS, com $r^{2}$ iguais a 0,93 e 
0,91 e Chang et al. (2001) em NIRS, com $r^{2}$ de 0,87 e 0,85 para carbono e nitrogênio totais do solo. Morgan et al. (2009) e Aichi et al. (2009) obtiveram resultados nem tão bons para carbono $(0,73$ e 0,83$)$ usando NIRS.

Um provável erro instrumental pode ter ocasionado tais resultados nas predições de CT e NT, visto que estes elementos foram bem modelados por NIRS ou DRIFTS por todos esses autores.

Surpreendentemente, os menores erros de validação externa foram obtidos na predição da razão $\mathrm{C} / \mathrm{N}$ (Tabela 21), talvez devido à amplificação da variabilidade dos dados ocasionada por esse cálculo. Isto está de acordo com o poder de modelagem de $\mathrm{C} / \mathrm{N}$ total ilustrada na Figura 33, contrariando os resultados obtidos por Ludwig et al. (2002).

Tabela 21 Dados de validação cruzada e externa para os modelos de calibração em NIRS e DRIFTS para C/N

\begin{tabular}{lccccccccc}
\hline \multicolumn{1}{c}{ Modelo } & NC $^{1}$ & $\mathbf{R V C}^{2}$ & $\mathbf{S E V}^{3}$ & $\mathbf{N V}^{4}$ & $\mathbf{N F}^{5}$ & Intecepto $^{\text {Inclinação }}$ & RVE $^{6}$ & Erro (\%) $^{\text {In }}$ \\
\hline CNPAF NIRS & 55 & 0,5579 & 2,83 & 15 & 3 & 6,05 & 0,55 & 0,5233 & 9,58 \\
CNPAF DRIFTS & 56 & 0,7967 & 2,02 & 14 & 3 & 4,95 & 0,63 & 0,4202 & 9,54 \\
CPPSE NIRS & 26 & 0,3377 & 2,11 & 7 & 4 & 8,84 & 0,29 & 0,4392 & 8,55 \\
CPPSE DRIFTS & 39 & 0,3120 & 6,01 & 10 & 5 & 3,01 & 0,55 & 0,7576 & 134,17 \\
MATAS NIRS & 15 & 0,5516 & 2,83 & 4 & 3 & 0,19 & 0,97 & 0,7787 & 4,85 \\
MATAS DRIFTS & 23 & 0,8636 & 3,45 & 6 & 2 & 5,31 & 0,23 & 0,5981 & 196,86 \\
TODOS NIRS & 82 & 0,4729 & 2,60 & 21 & 2 & 9,92 & 0,29 & 0,7029 & 9,41 \\
TODOS DRIFTS & 95 & 0,7529 & 3,17 & 24 & 10 & 7,08 & 0,32 & 0,4178 & 146,97 \\
MANEJADOS NIRS & 67 & 0,3390 & 2,84 & 17 & 6 & 6,14 & 0,55 & 0,6889 & 10,72 \\
MANEJADOS DRIFTS & 72 & 0,5550 & 3,37 & 18 & 9 & 6,11 & 0,61 & 0,5434 & 47,13 \\
\hline
\end{tabular}

${ }^{1} \overline{\mathrm{NC}}=$ número de amostras de calibração; ${ }^{2} \mathrm{RVC}=$ coeficiente de regressão obtido pela validação cruzada; ${ }^{3} \mathrm{SEV}=$ erro de validação cruzada (ver Equação 9); ${ }^{4} \mathrm{NV}=$ número de amostras de validação; ${ }^{5} \mathrm{NF}=$ número de fatores ou PCs utilizados no cálculo da PLS; ${ }^{6} \mathrm{RVE}=$ coeficiente de regressão obtido pela validação externa.

Os valores de COT, CT, NT e C/N total, preditos para as amostras de validação, pelos melhores modelos de calibração, são detalhados na Tabela 22. 
Tabela 22 Valores medidos de referência e preditos pelos modelos CNPAF DRIFTS (COT E CT) E MATAS NIRS (C/N total)

\begin{tabular}{|c|c|c|c|c|c|c|c|c|}
\hline \multicolumn{3}{|c|}{ COT } & \multicolumn{3}{|c|}{ CT } & \multicolumn{3}{|c|}{$\mathrm{C} / \mathrm{N}$ total } \\
\hline Amostras & Medidos & Preditos & Amostras & Medidos & Preditos & Amostras & Medidos & Preditos \\
\hline AF11 & 21,84 & 24,07 & AF45 & 12,18 & 13,32 & PS32 & 13,26 & 11,68 \\
\hline AF12 & 20,28 & 24,07 & AF67 & 15,42 & 15,83 & PS41 & 12,50 & 12,90 \\
\hline AF31 & 20,28 & 21,88 & AF73 & 13,81 & 13,11 & AF70 & 15,30 & 15,05 \\
\hline AF35 & 23,40 & 22,98 & AF74 & 13,27 & 12,09 & AF73 & 13,81 & 14,17 \\
\hline AF36 & 20,28 & 22,86 & AF79 & 13,33 & 13,40 & - & - & - \\
\hline AF39 & 20,28 & 21,35 & AF80 & 13,22 & 14,05 & - & - & - \\
\hline AF41 & 33,54 & 31,81 & AF83 & 14,39 & 15,24 & - & - & - \\
\hline AF43 & 35,88 & 33,00 & AF87 & 12,18 & 13,72 & - & - & - \\
\hline AF44 & 30,00 & 26,85 & AF92 & 13,08 & 13,18 & - & - & - \\
\hline AF45 & 21,84 & 25,24 & AF93 & 12,36 & 13,21 & - & - & - \\
\hline AF46 & 20,28 & 22,22 & AF99 & 13,21 & 13,51 & - & - & - \\
\hline AF67 & 47,58 & 34,56 & AF102 & 16,03 & 13,64 & - & - & - \\
\hline AF68 & 42,90 & 35,73 & AF104 & 12,18 & 7,75 & - & - & - \\
\hline AF69 & 40,56 & 36,79 & AF107 & 11,93 & 14,42 & - & - & - \\
\hline AF71 & 38,22 & 34,36 & - & - & - & - & - & - \\
\hline AF72 & 47,58 & 36,60 & - & - & - & - & - & - \\
\hline AF73 & 46,02 & 41,27 & - & - & - & - & - & - \\
\hline AF79 & 24,18 & 32,50 & - & - & - & - & - & - \\
\hline AF80 & 25,74 & 35,38 & - & - & - & - & - & - \\
\hline AF81 & 26,52 & 36,41 & - & - & - & - & - & - \\
\hline AF82 & 28,08 & 26,14 & - & - & - & - & - & - \\
\hline AF83 & 30,42 & 30,48 & - & - & - & - & - & - \\
\hline AF102 & 26,52 & 29,14 & - & - & - & - & - & - \\
\hline AF107 & 28,08 & 29,61 & - & - & - & - & - & - \\
\hline AF109 & 44,46 & 39,29 & - & - & - & - & - & - \\
\hline
\end{tabular}

O modelo que resultou em melhores predições de $\mathrm{C} / \mathrm{N}$ total foi MATAS NIRS, o mesmo que se mostrou mais eficiente na quantificação de argila e areia. Este fato provoca um questionamento sobre a habilidade desta técnica na predição da matéria orgânica do solo. Como a textura influencia grandemente na retenção da matéria orgânica pela formação de complexos com argila e promoção da humificação, esse resultado pode ser consequiência da sensibilidade de NIRS ao tamanho de partícula.

Madari et al. (2006a) verificaram que as predições para CT são melhores em NIRS e DRIFTS quando existe homogeneidade de composição textural. Caso contrário, o infravermelho médio demonstra maior robustez trazendo valores mais precisos que o 
infravermelho próximo. Esta interferência da textura não foi detectada pelos autores na determinação do nitrogênio total.

Considerando esse estudo de Madari et al. (2006a), concluiu-se que existe sim alguns sinais de matéria orgânica nos espectros de NIRS, responsáveis pela calibração de C/N. Além disso, segundo Chang et al. (2001), o cálculo da primeira derivada pode atenuar o efeito de distribuição de tamanho das partículas.

Concordando com a maior robustez verificada em DRIFTS por Madari et al. (2006a), esta região do infravermelho também proporcionou melhores índices de validação em CT e NT, sendo superado por NIRS apenas na predição de C/N total.

Assim, a faixa do infravermelho médio mostrou-se mais sensível à presença de matéria orgânica, apesar dos fortes sinais de componentes minerais também detectados, sendo mais indicado para este tipo de predição. A razão C/N pode ser calculada após a partir desses valores de carbono e nitrogênio preditos, não sendo imprescindível a sua predição.

No caso de usar os espectros inteiros, é recomendável a realização de uma calibração para cada local amostrado, tendo em vista que as diferenças de mineralogia são mais marcantes do que as diferenças nos teores de carbono e nitrogênio. 

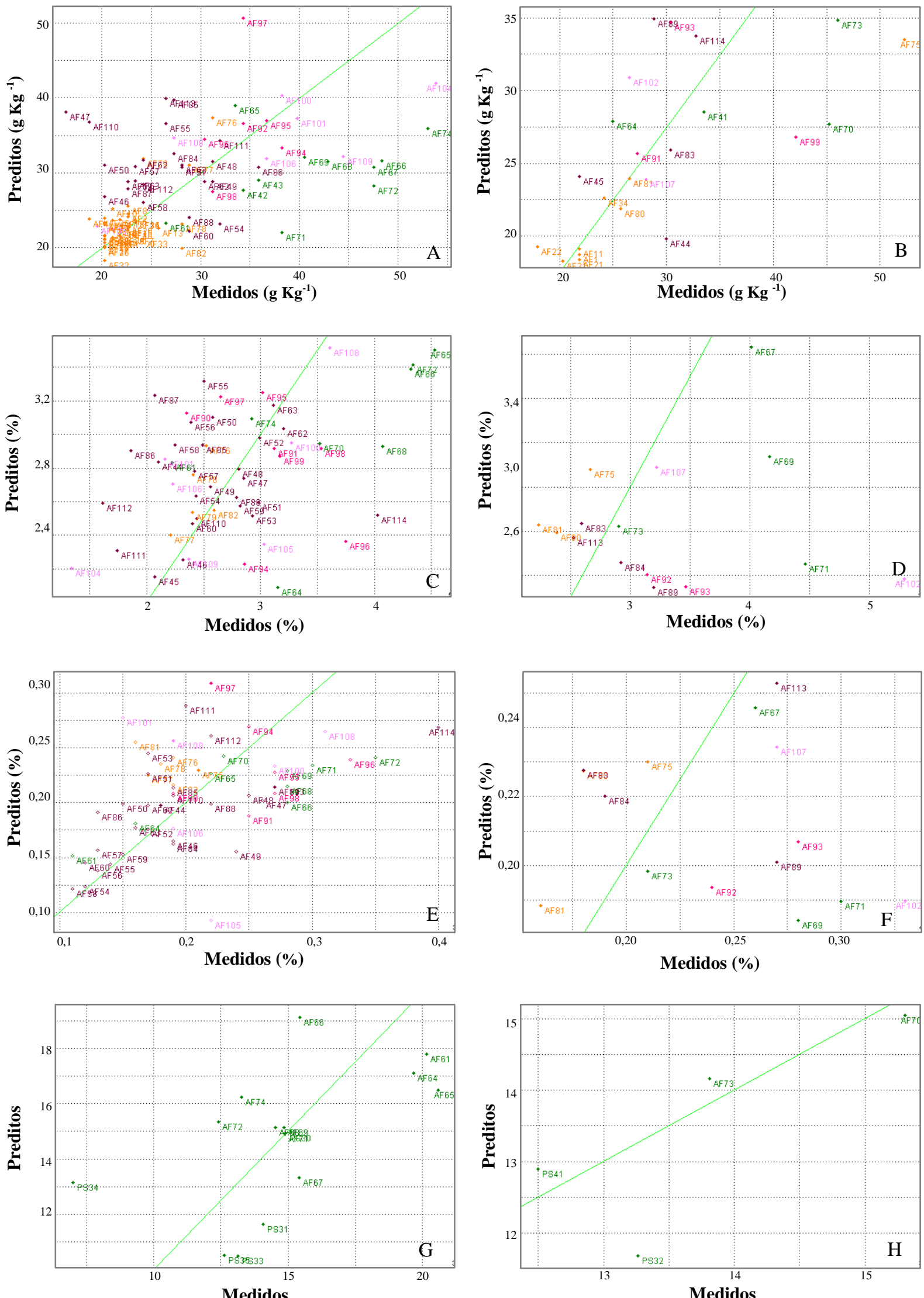

Figura 36 Gráficos dos valores medidos (referência) versus valores preditos, resultantes da validação cruzada (A, C e E) e da validação externa (B, D e F) de modelos calculados com dados de NIRS. (A) e (B) COT pelo modelo CNPAF; (C) e (D) CT pelo modelo CNPAF; (E) e (F) NT pelo modelo CNPAF; (G) e (H) CN pelo modelo MATAS. As linhas indicam valores 1:1. 

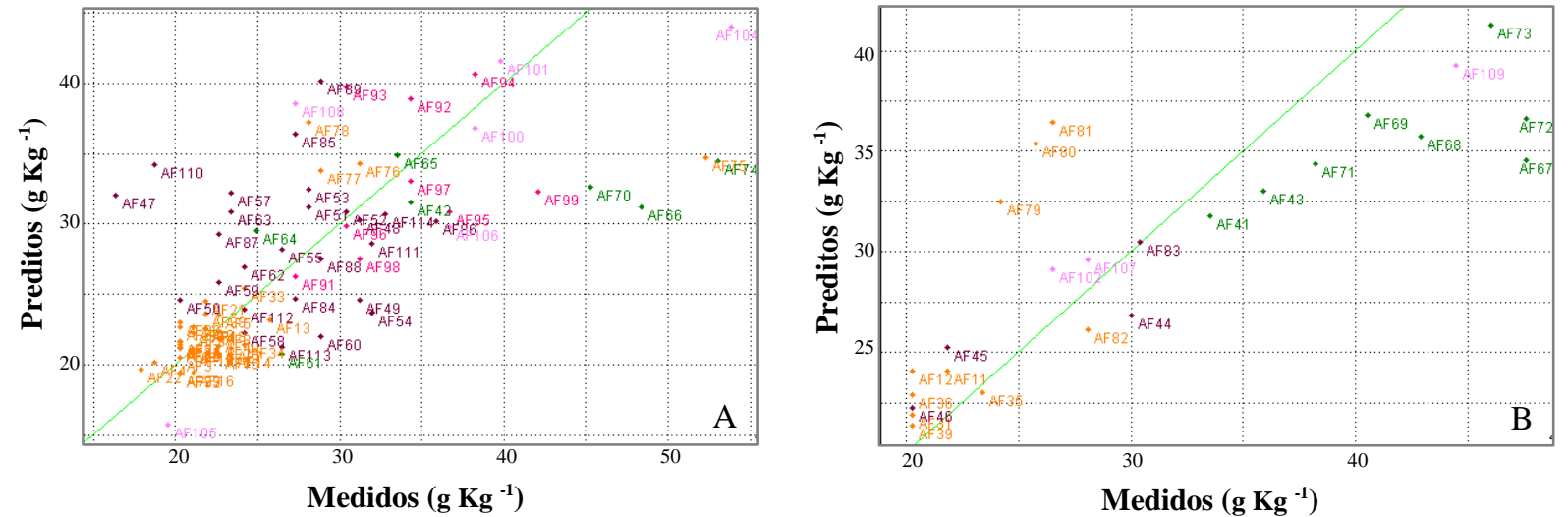

Medidos $\left(\mathrm{g} \mathrm{Kg}^{-1}\right)$
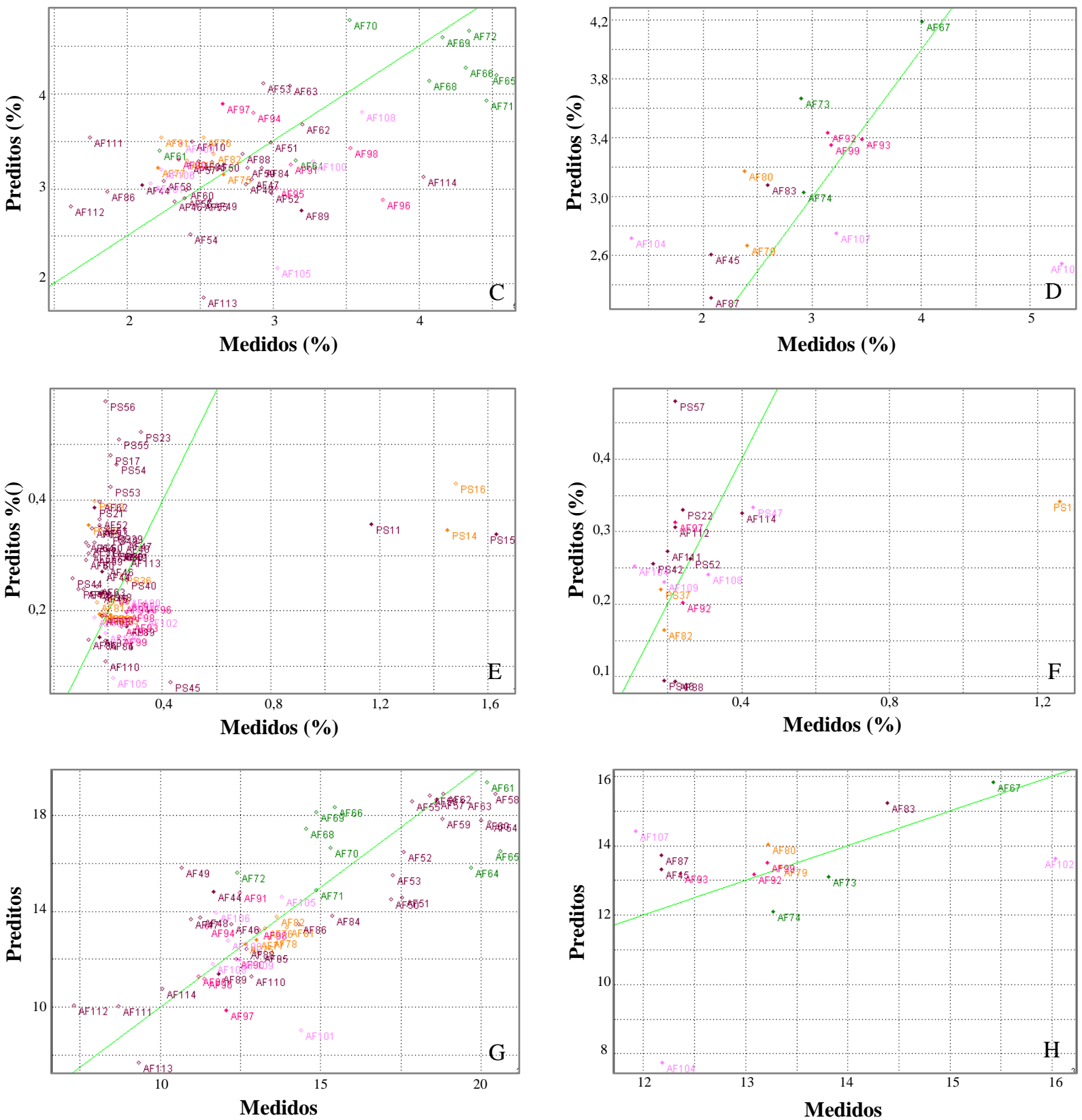

Figura 37 Gráficos dos valores medidos versus valores preditos, resultantes da validação cruzada (A, C e E) e da validação externa (B, D e F) de modelos calculados com dados de DRIFTS. (A) e (B) COT pelo modelo CNPAF; (C) e (D) CT pelo modelo CNPAF; (E) e (F) NT pelo modelo Manejados; (G) e (H) C/N pelo modelo CNPAF. As linhas indicam valores 1:1. 


\subsection{Biomassa microbiana}

Neste grupo de atributos do solo, denominado biomassa microbiana, estão incluídos o carbono e o nitrogênio de origem microbiana, a respiração basal do solo, o quociente metabólico, a relação $\mathrm{C} / \mathrm{N}$ microbiana e o quociente microbiano.

A PCA com os dados de biomassa microbiana foi realizada utilizando-se seis componentes principais ou fatores, porém apenas três foram necessários (Figura 38).
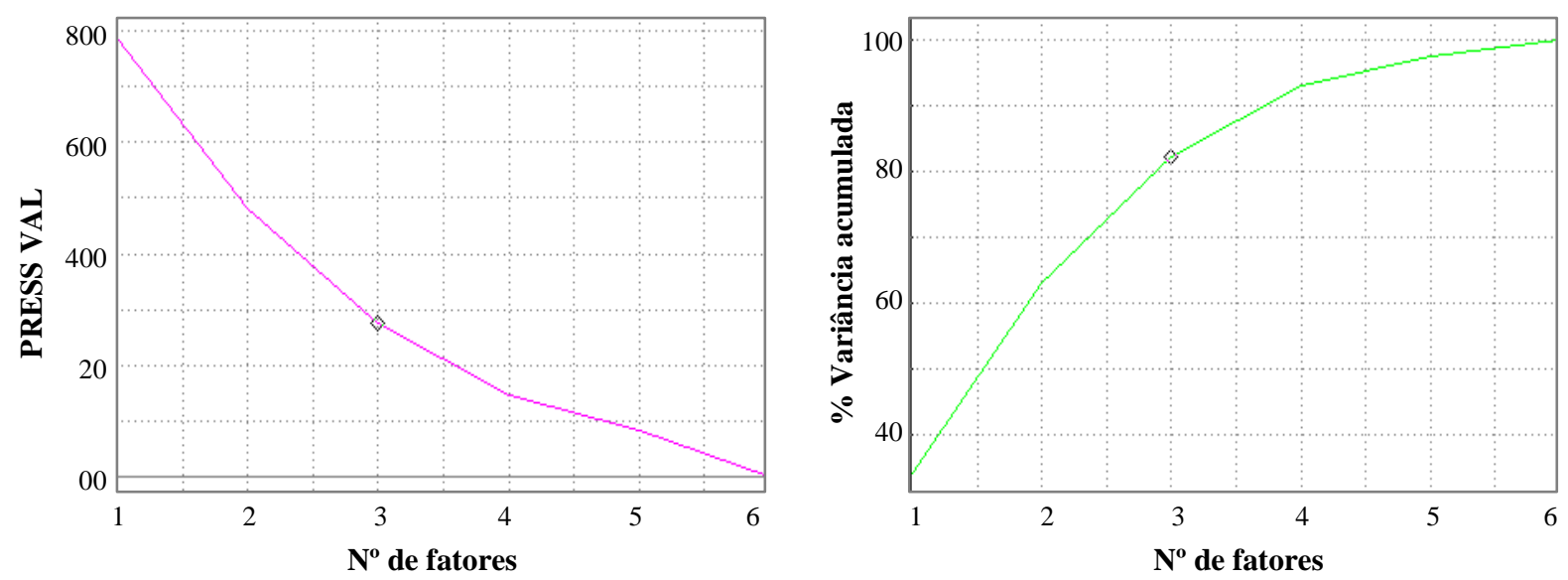

Figura 38 Gráfico de PRESS VAL versus número de fatores incluídos na PCA Biomassa Microbiana.

De acordo com a Tabela 23, utilizando-se três fatores, acumula-se uma variância de $82,32 \%$, explicada por essas três componentes principais, e atinge-se um valor de mediano de PRESS VAL, igual a 274,71.

Tabela 23 Variância dos dados de biomassa microbiana explicada pelas 6 PCs e erros de calibração e validação da PCA

\begin{tabular}{lccccc}
\hline & Variância & Percentual & \% Cumulativo & Press Val & Press Cal \\
\hline Fator 1 & 324,07 & 34,18 & 34,18 & 787,21 & 623,93 \\
Fator 2 & 273,31 & 28,83 & 63,01 & 482,03 & 350,63 \\
Fator 3 & 183,02 & 19,31 & 82,32 & 274,71 & 167,61 \\
Fator 4 & 100,51 & 10,60 & 92,92 & 148,07 & 67,10 \\
Fator 5 & 42,83 & 4,52 & 97,44 & 84,91 & 24,28 \\
Fator 6 & 24,28 & 2,56 & 100,00 & 0,00 & 0,00 \\
\hline
\end{tabular}

Em seguida são apresentados os gráficos de scores (Figura 39), nos quais se observa um acúmulo de amostras em torno do centro. Algumas amostras da Embrapa Pecuária 
Sudeste se distanciaram na direção do canto superior direito. Estes solos são provenientes de ambientes de matas nativas, separadas pelo alto teor de $\mathrm{C}_{\mathrm{MIC}}$ e $\mathrm{N}_{\mathrm{MIC}}$, atributos que se situam no mesmo local no gráfico de loadings (Figura 39D).

Quanto às amostras de solos com culturas e com mata ciliar, houve uma pequena segregação entre amostras de mesma classe, porém permeadas pelas amostras de pastagens. Enquanto as de mata ciliar se caracterizaram por uma atividade respiratória mais intensa e consequente alto quociente metabólico, as provenientes de culturas se destacaram pela alta relação $\mathrm{C} / \mathrm{N}$.
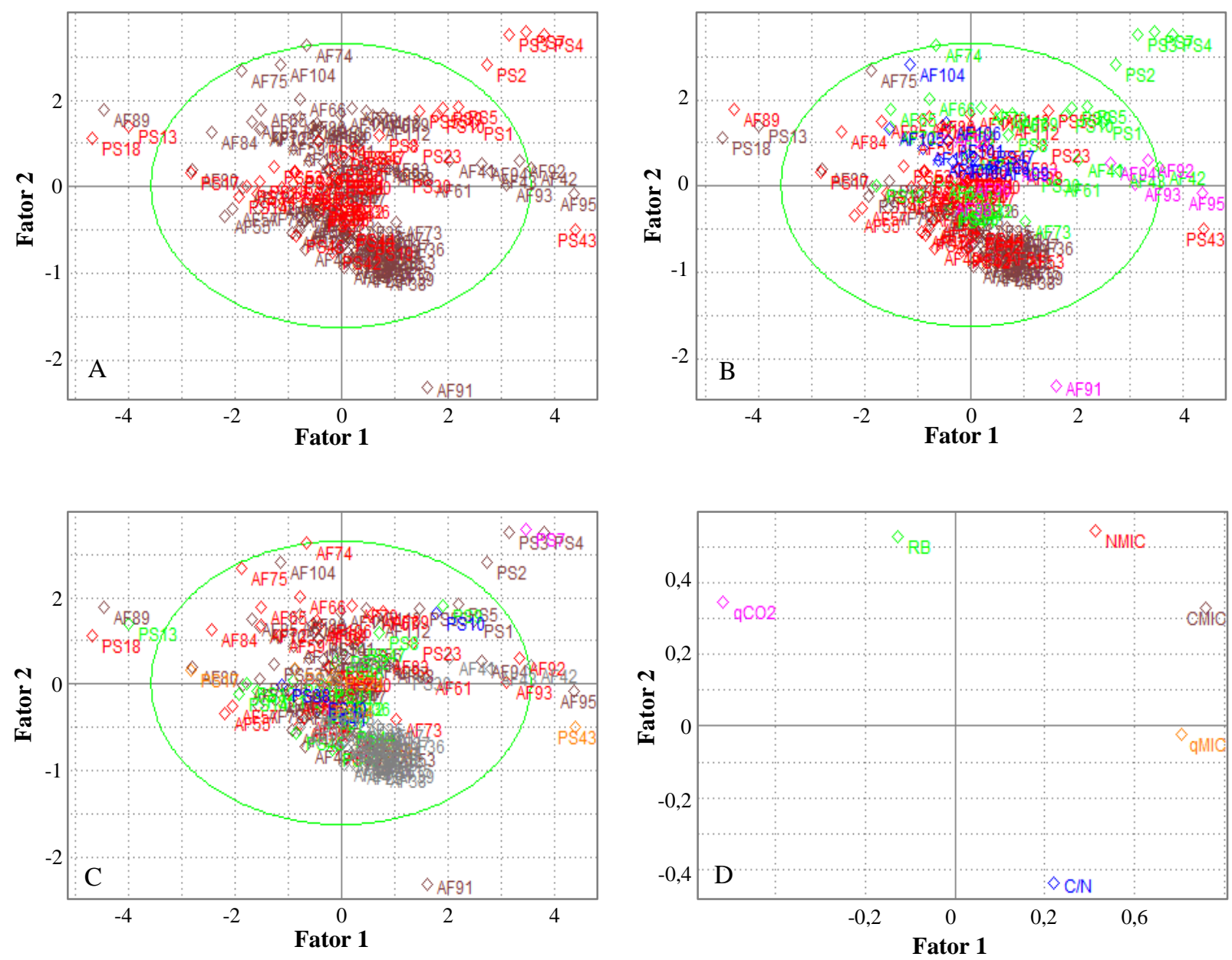

Figura 39 Gráficos de scores (A, B e C) e de loadings (D), Fator 1 versus Fator 2 resultantes de PCAs com dados auto-escalados de biomassa microbiana. Classes ativadas: (A) Localidade - cinza Santo Antônio de Goiás e vermelho São Carlos; (B) Uso do solo - cinza culturas, verde matas, vermelho pastagens, azul matas ciliares e rosa integração lavoura-pecuária; (C) Textura - cinza, solos de textura não determinada, roxo solos argilosos, vermelho muito argilosos, verde franco argila arenosos, rosa franco argiloso, azul franco arenosos, laranja argilo arenosos, cinza claro areia franca. 
Conforme esperado, as amostras de mata se localizaram em região de altos teores de $\mathrm{C}_{\text {MIC }}$ e $\mathrm{N}_{\text {MIC. }}$ Quanto ao quociente microbiano, as amostras PS 44-45 e AF 92-95, apresentaram os maiores valores, sendo visualizadas à direita no gráfico de scores. Pode-se afirmar que, em geral, os solos manejados possuem um maior quociente microbiano que os solos de matas nativas, justamente porque estes últimos contêm grande quantidade de carbono orgânico total, incluindo frações de difícil decomposição.

O carbono microbiano, nesta análise, demonstrou ter maior poder de modelagem (Figura 40), pois interferiu de maneira significativa na distribuição das amostras no gráfico de scores, assim como o $\mathrm{N}_{\mathrm{MIC}}$. Entretanto, esta medida está relacionada também com os maiores resíduos, ou seja, a diferença entre os valores originais e os valores da matriz reconstruída com três fatores foi grande $\left( \pm 200 \mathrm{~g} \mathrm{Kg}^{-1}\right.$ de carbono $)$.
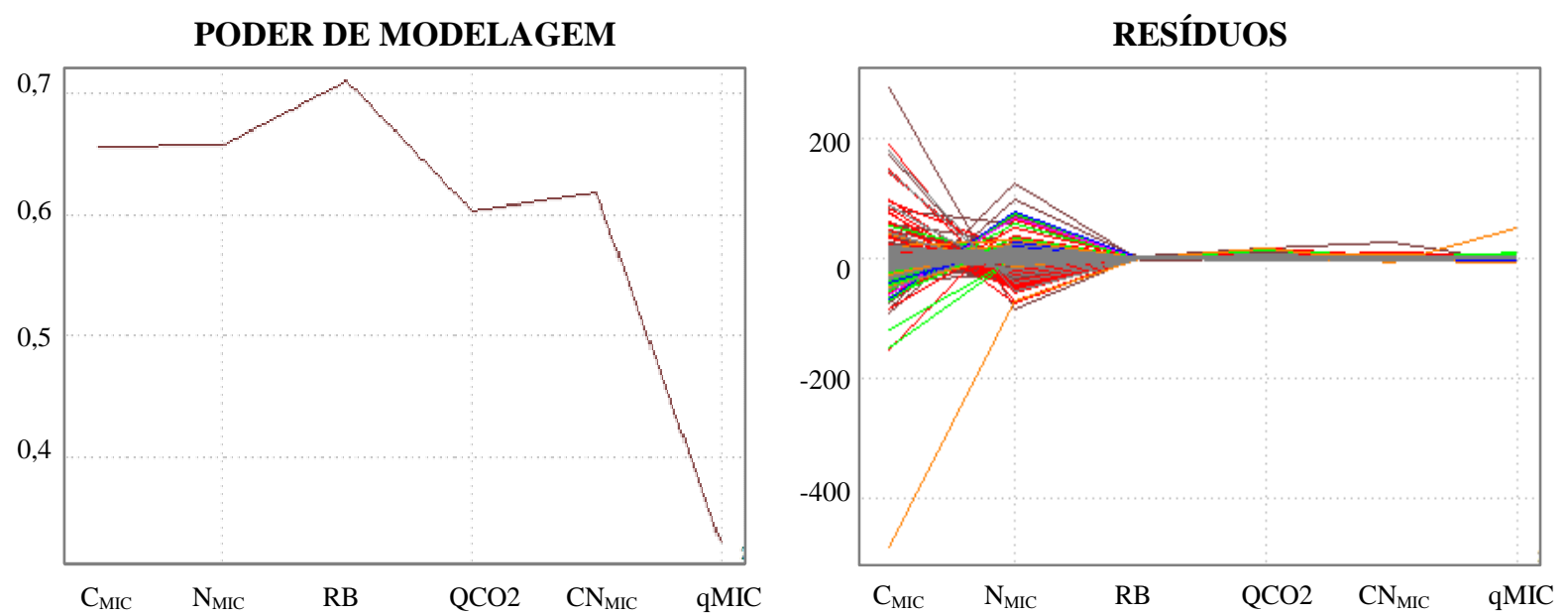

Figura 40 Gráficos apresentando poder de modelagem e resíduos associados a cada atributo componente da biomassa microbiana do solo: $\mathrm{N}_{\mathrm{MIC}}, \mathrm{C}_{\mathrm{MIC}}, \mathrm{RB}, \mathrm{qCO}_{2}, \mathrm{CN}_{\mathrm{MIC}}$ e qMIC.

Os gráficos de regressão entre valores preditos e medidos provenientes das validações cruzada e externa são apresentados nas Figuras 41 e 42. Os parâmetros utilizados para a comparação entre as diferentes calibrações para biomassa estão contidos nas Tabelas 24 a 29. 
Tabela 24 Dados de validação cruzada e externa para os modelos de calibração em NIRS e DRIFTS para $C_{\text {MIC }}$

\begin{tabular}{lccccccccc}
\hline \multicolumn{1}{c}{ Modelo } & NC $^{1}$ & $\mathbf{R V C}^{2}$ & $\mathbf{S E V}^{3}$ & $\mathbf{N V}^{4}$ & $\mathbf{N F}^{5}$ & Intecepto $^{\text {Inclinação }}$ & RVE $^{6}$ & Erro $(\%)^{\text {\% }}$ \\
\hline CNPAF NIRS & 91 & 0,3363 & 147,48 & 20 & 2 & 248,09 & 0,18 & 0,6207 & 35,33 \\
CNPAF DRIFTS & 84 & 0,4396 & 151,69 & 25 & 6 & 202,17 & 0,46 & 0,4970 & 53,66 \\
CPPSE NIRS & 42 & 0,6284 & 141,51 & 10 & 6 & 131,04 & 0,60 & 0,6440 & 82,60 \\
CPPSE DRIFTS & 39 & 0,6811 & 127,98 & 11 & 5 & 113,82 & 0,68 & 0,8220 & 75,61 \\
MATAS NIRS & 17 & 0,4655 & 180,80 & 15 & 3 & 305,48 & 0,51 & 0,4547 & 75,95 \\
MATAS DRIFTS & 25 & 0,7279 & 129,35 & 7 & 2 & 344,09 & 0,37 & 0,6545 & 81,01 \\
TODOS NIRS & 127 & 0,066 & 155,66 & 35 & 1 & 308,32 & 0,04 & 0,2487 & 94,80 \\
TODOS DRIFTS & 126 & 0,5012 & 143,74 & 33 & 7 & 193,74 & 0,46 & 0,5746 & 62,90 \\
MANEJADOS NIRS & 107 & 0,2881 & 116,67 & 23 & 1 & 252,95 & 0,10 & 0,5440 & 46,69 \\
MANEJADOS DRIFTS & 101 & 0,4814 & 116,13 & 27 & 4 & 176,47 & 0,31 & 0,4492 & 63,13
\end{tabular}

${ }^{1} \mathrm{NC}=$ número de amostras de calibração; ${ }^{2} \mathrm{RVC}=$ coeficiente de regressão obtido pela validação cruzada; ${ }^{3} \mathrm{SEV}=$ erro de validação cruzada (ver Equação 9); ${ }^{4} \mathrm{NV}=$ número de amostras de validação; ${ }^{5} \mathrm{NF}=$ número de fatores ou PCs utilizados no cálculo da PLS; ${ }^{6} \mathrm{RVE}=$ coeficiente de regressão obtido pela validação externa.

Tabela 25 Dados de validação cruzada e externa para os modelos de calibração em NIRS e DRIFTS para N MIC $_{\text {M }}$

\begin{tabular}{lccccccccc}
\hline \multicolumn{1}{c}{ Modelo } & NC $^{1}$ & $\mathbf{R V C}^{1}$ & $\mathbf{S E V}^{2}$ & $\mathbf{N V}^{4}$ & $\mathbf{N F}^{3}$ & Intecepto $^{\text {Inclinação }}$ & RVE $^{4}$ & Erro $(\%)^{(\%, 91}$ \\
\hline CNPAF NIRS & 91 & 0,6168 & 18,81 & 20 & 2 & 37,97 & 0,24 & 0,6295 & 35,91 \\
CNPAF DRIFTS & 84 & 0,6506 & 21,06 & 25 & 9 & 13,84 & 0,87 & 0,7488 & 33,72 \\
CPPSE NIRS & 42 & 0,5191 & 79,82 & 10 & 4 & 65,19 & 0,80 & 0,7555 & 104,00 \\
CPPSE DRIFTS & 39 & 0,7530 & 59,38 & 11 & 6 & 25,21 & 0,77 & 0,7319 & 52,52 \\
MATAS NIRS & 17 & 0,5898 & 84,50 & 15 & 2 & 69,40 & 0,59 & 0,7130 & 79,16 \\
MATAS DRIFTS & 25 & 0,8589 & 53,15 & 7 & 2 & 77,21 & 0,56 & 0,6966 & 51,67 \\
TODOS NIRS & 127 & 0,4838 & 54,58 & 35 & 1 & 51,97 & 0,28 & 0,5213 & 41,06 \\
TODOS DRIFTS & 126 & 0,6313 & 45,37 & 33 & 3 & 53,02 & 0,29 & 0,5213 & 41,02 \\
MANEJADOS NIRS & 107 & 0,6880 & 23,40 & 23 & 5 & 29,44 & 0,44 & 0,5054 & 34,08 \\
MANEJADOS DRIFTS & 101 & 0,7464 & 22,25 & 27 & 4 & 31,34 & 0,40 & 0,4565 & 30,00
\end{tabular}

${ }^{1} \mathrm{NC}=$ número de amostras de calibração; ${ }^{2} \mathrm{RVC}=$ coeficiente de regressão obtido pela validação cruzada; ${ }^{3} \mathrm{SEV}=$ erro de validação cruzada (ver Equação 9); ${ }^{4} \mathrm{NV}=$ número de amostras de validação; ${ }^{5} \mathrm{NF}=$ número de fatores ou PCs utilizados no cálculo da PLS; ${ }^{6} \mathrm{RVE}=$ coeficiente de regressão obtido pela validação externa.

Tabela 26 Dados de validação cruzada e externa para os modelos de calibração em NIRS e DRIFTS para RB

\begin{tabular}{lccccccccc}
\hline \multicolumn{1}{c}{ Modelo } & NC $^{1}$ & RVC $^{1}$ & SEV $^{2}$ & NV $^{4}$ & NF $^{3}$ & Intecepto $^{\text {Inclinação }}$ & RVE $^{4}$ & Erro (\%) $^{\text {(\%) }}$ \\
\hline CNPAF NIRS & 91 & 0,6038 & 1,39 & 20 & 2 & 1,35 & 0,38 & 0,7031 & 96,28 \\
CNPAF DRIFTS & 84 & 0,5983 & 1,51 & 25 & 3 & 1,48 & 0,30 & 0,3890 & 54,96 \\
CPPSE NIRS & 42 & 0,6197 & 0,49 & 10 & 4 & 1,26 & $-0,05$ & $-0,1532$ & 37,69 \\
CPPSE DRIFTS & 39 & 0,5214 & 0,56 & 11 & 3 & 1,47 & 0,03 & 0,0616 & 51,42 \\
MATAS NIRS & 17 & 0,6369 & 1,59 & 15 & 1 & 1,91 & 0,49 & 0,7112 & 91,42 \\
MATAS DRIFTS & 25 & 0,8014 & 1,09 & 7 & 4 & 1,87 & 0,12 & 0,3890 & 72,70 \\
TODOS NIRS & 127 & 0,5691 & 1,17 & 35 & 2 & 1,50 & 0,27 & 0,6161 & 87,12 \\
TODOS DRIFTS & 126 & 0,5767 & 1,20 & 33 & 4 & 1,55 & 0,30 & 0,5264 & 120,72 \\
MANEJADOS NIRS & 107 & 0,5275 & 1,21 & 23 & 4 & 1,57 & 0,39 & 0,7223 & 47,18 \\
MANEJADOS DRIFTS & 101 & 0,5862 & 1,14 & 27 & 4 & 1,20 & 0,42 & 0,5862 & 68,52
\end{tabular}

${ }^{1} \overline{\mathrm{NC}}=$ número de amostras de calibração; ${ }^{2} \mathrm{RVC}=$ coeficiente de regressão obtido pela validação cruzada; ${ }^{3} \mathrm{SEV}=$ erro de validação cruzada (ver Equação 9); ${ }^{4} \mathrm{NV}=$ número de amostras de validação; ${ }^{5} \mathrm{NF}=$ número de fatores ou PCs utilizados no cálculo da PLS; ${ }^{6} \mathrm{RVE}=$ coeficiente de regressão obtido pela validação externa. 
Tabela 27 Dados de validação cruzada e externa para os modelos de calibração em NIRS e DRIFTS para qCO ${ }_{2}$

\begin{tabular}{lccccccccc}
\hline \multicolumn{1}{c}{ Modelo } & NC $^{1}$ & $\mathbf{R V C}^{1}$ & $\mathbf{S E V}^{2}$ & $\mathbf{N V}^{4}$ & $\mathbf{N F}^{3}$ & Intecepto $^{\text {Inclinação }}$ & RVE $^{4}$ & Erro $(\%)^{\text {(\%) }}$ \\
\hline CNPAF NIRS & 91 & 0,5359 & 5,72 & 20 & 2 & 5,56 & 0,37 & 0,5773 & 86,19 \\
CNPAF DRIFTS & 84 & 0,5778 & 5,76 & 25 & 2 & 6,23 & 0,37 & 0,4828 & 59,50 \\
CPPSE NIRS & 42 & 0,2819 & 3,81 & 10 & 2 & 5,82 & 0,05 & 0,4380 & 42,48 \\
CPPSE DRIFTS & 39 & 0,1570 & 6,48 & 11 & 2 & 7,65 & 0,14 & 0,5841 & 93,46 \\
MATAS NIRS & 17 & 0,4791 & 5,09 & 15 & 1 & 5,80 & 0,32 & 0,5285 & 135,54 \\
MATAS DRIFTS & 25 & 0,6039 & 4,33 & 7 & 3 & 3,58 & 0,08 & 0,2717 & 38,25 \\
TODOS NIRS & 127 & 0,5431 & 4,31 & 35 & 2 & 7,15 & 0,05 & 0,2009 & 98,42 \\
TODOS DRIFTS & 126 & 0,4536 & 5,82 & 33 & 4 & 8,65 & 0,11 & 0,2997 & 162,62 \\
MANEJADOS NIRS & 107 & 0,2072 & 6,89 & 23 & 1 & 8,90 & 0,04 & 0,3000 & 72,43 \\
MANEJADOS DRIFTS & 101 & 0,4871 & 6,10 & 27 & 4 & 7,63 & 0,16 & 0,3285 & 106,47
\end{tabular}

${ }^{1} \overline{\mathrm{NC}}=$ número de amostras de calibração $;{ }^{2} \mathrm{RVC}=$ coeficiente de regressão obtido pela validação cruzada; ${ }^{3} \mathrm{SEV}=$ erro de validação cruzada (ver Equação 9); ${ }^{4} \mathrm{NV}=$ número de amostras de validação; ${ }^{5} \mathrm{NF}=$ número de fatores ou PCs utilizados no cálculo da PLS; ${ }^{6} \mathrm{RVE}=$ coeficiente de regressão obtido pela validação externa.

Tabela 28 Dados de validação cruzada e externa para os modelos de calibração em NIRS e DRIFTS para C/N $\mathrm{NIC}$

\begin{tabular}{lccccccccc}
\hline \multicolumn{1}{c}{ Modelo } & NC $^{1}$ & $\mathbf{R V C}^{1}$ & $\mathbf{S E V}^{2}$ & $\mathbf{N V}^{4}$ & $\mathbf{N F}^{3}$ & Intecepto $^{\text {Inclinação }}$ & RVE $^{4}$ & Erro $(\%)^{\text {(\%) }}$ \\
\hline CNPAF NIRS & 91 & $-0,1078$ & 4,64 & 20 & 1 & 5,94 & 0,16 & 0,2861 & 44,81 \\
CNPAF DRIFTS & 84 & 0,1188 & 4,76 & 25 & 3 & 6,49 & 0,09 & 0,1027 & 45,27 \\
CPPSE NIRS & 42 & 0,0890 & 5,83 & 10 & 7 & 3,00 & $-0,04$ & $-0,1825$ & 62,80 \\
CPPSE DRIFTS & 39 & 0,1400 & 2,08 & 11 & 2 & 3,71 & $-0,17$ & $-0,3957$ & 79,60 \\
MATAS NIRS & 17 & 0,7488 & 1,24 & 15 & 2 & 3,09 & 0,22 & 0,6226 & 43,63 \\
MATAS DRIFTS & 25 & 0,4184 & 3,29 & 7 & 5 & 1,59 & 1,00 & 0,6530 & 79,76 \\
TODOS NIRS & 127 & 0,2975 & 4,00 & 35 & 1 & 4,39 & 0,31 & 0,6093 & 107,78 \\
TODOS DRIFTS & 126 & 0,4220 & 3,84 & 33 & 4 & 2,91 & 0,40 & 0,5057 & 59,63 \\
MANEJADOS NIRS & 107 & 0,2364 & 4,26 & 23 & 1 & 5,17 & 0,15 & 0,3509 & 94,28 \\
MANEJADOS DRIFTS & 101 & 0,3657 & 4,29 & 27 & 4 & 2,07 & 0,66 & 0,5575 & 68,51 \\
\hline
\end{tabular}

${ }^{1} \mathrm{NC}=$ número de amostras de calibração; ${ }^{2} \mathrm{RVC}=$ coeficiente de regressão obtido pela validação cruzada; ${ }^{3} \mathrm{SEV}=$ erro de validação cruzada (ver Equação 9); ${ }^{4} \mathrm{NV}=$ número de amostras de validação; ${ }^{5} \mathrm{NF}=$ número de fatores ou PCs utilizados no cálculo da PLS; ${ }^{6} \mathrm{RVE}=$ coeficiente de regressão obtido pela validação externa.

Tabela 29 Dados de validação cruzada e externa para os modelos de calibração em NIRS e DRIFTS para qMIC

\begin{tabular}{lccccccccc}
\hline \multicolumn{1}{c}{ Modelo } & NC $^{1}$ & RVC $^{1}$ & SEV $^{2}$ & NV $^{4}$ & $\mathbf{N F}^{3}$ & Intecepto $^{\text {Inclinação }}$ & RVE $^{4}$ & Erro (\%) $^{\text {(\% }}$ \\
\hline CNPAF NIRS & 89 & 0,2824 & 4,20 & 23 & 2 & 10,34 & 0,13 & 0,3041 & 65,90 \\
CNPAF DRIFTS & 84 & 0,4449 & 4,46 & 25 & 8 & 10,07 & 0,19 & 0,1585 & 56,04 \\
CPPSE NIRS & 40 & $-0,0757$ & 11,97 & 10 & 1 & 9,81 & 0,075 & 0,2186 & 56,13 \\
CPPSE DRIFTS & 39 & 0,1970 & 11,51 & 11 & 1 & 8,95 & 0,22 & 0,4594 & 120,92 \\
MATAS NIRS & 18 & 0,6622 & 4,16 & 15 & 4 & 9,13 & 0,43 & 0,4141 & 55,05 \\
MATAS DRIFTS & 25 & 0,5522 & 3,97 & 7 & 5 & 8,66 & 0,51 & 0,8746 & 58,74 \\
TODOS NIRS & 129 & $-0,1141$ & 7,39 & 32 & 1 & 11,58 & 0,02 & 0,0875 & 65,68 \\
TODOS DRIFTS & 126 & 0,1722 & 7,65 & 33 & 3 & 9,68 & 0,00 & 0,00 & 64,54 \\
MANEJADOS NIRS & 102 & 0,1881 & 7,84 & 26 & 3 & 13,35 & $-0,080$ & $-0,1404$ & 82,16 \\
MANEJADOS DRIFTS & 101 & 0,2428 & 8,35 & 27 & 3 & 8,71 & 0,25 & 0,4047 & 72,94 \\
\hline
\end{tabular}

${ }^{1} \overline{\mathrm{NC}}=$ número de amostras de calibração; ${ }^{2} \mathrm{RVC}=$ coeficiente de regressão obtido pela validação cruzada; ${ }^{3} \mathrm{SEV}=$ erro de validação cruzada (ver Equação 9); ${ }^{4} \mathrm{NV}=$ número de amostras de validação; ${ }^{5} \mathrm{NF}=$ número de fatores ou PCs utilizados no cálculo da PLS; ${ }^{6} \mathrm{RVE}=$ coeficiente de regressão obtido pela validação externa. 
$\mathrm{C}_{\text {MIC }}$ foi mais bem predito por CPPSE DRIFTS, porém CNPAF NIRS apresentou o menor Erro\%. No gráfico de Y FIT deste modelo observam-se algumas amostras acima da linha 1:1 e outras abaixo, indicando duas retas possíveis. As amostras de cima são solos com alta taxa de respiração basal e $\mathrm{qCO}_{2}$, o que pode significar diferença qualitativa de matéria orgânica e comunidade microbiana.

Os valores de RVE obtidos para $\mathrm{C}_{\mathrm{MIC}}$ com CPPSE DRIFTS e $\mathrm{N}_{\mathrm{MIC}}$ com CNPAF DRIFTS são comparáveis com os coeficientes de regressão publicados por Ludwig et al. (2002) (0,76 e 0,74) e melhores que aqueles obtidos por R. Rinnan e A. Rinnan (2007) (0,79 e 0,60) em NIRS. O melhor modelo para $\mathrm{C}_{\mathrm{MIC}}$ superou aquele alcançado por Chang et al. (2001) $(r=0,60$ e $\mathrm{SEV}=389,71)$, porém estes e os modelos para $\mathrm{N}_{\mathrm{MIC}}$ não foram melhores que os resultados de Coûteaux et al. (2003) $(0,955$ e 0,969) e de Terhoeven-Urselmans et al. (2008) $(0,99$ e 1,03) em NIRS. Os modelos obtidos para RB (MANEJADOS NIRS), por sua vez, não confirmaram os valores alcançados por Chang et al. (2001), Ludwig et al. (2002) e Terhoeven-Urselmans (2008) $(r=0,82 ; r=0,96 ; r=1,00)$.

Em alguns dos trabalhos citados foi utilizado um maior número de amostras na validação (NV) do que na calibração (NC). Ludwig et al. (2002) adotaram $n_{C}=40$ e $n_{V}=80$ para calibrar com PLS modificado, ressaltando a importância de escolher amostras de calibração que cobrem toda a faixa de valores observado, e Chang et al. (2001) dividiram as amostras em $n_{C}=30$ e $n_{V}>700$ para posterior regressão com PCR.

Chang et al. (2001) observaram que as predições de propriedades bioquímicas do solo por NIRS foram mais precisas dentro de grupos de amostras de mesmo local e em solos com maiores teores de matéria orgânica, o que foi confirmado no caso de $\mathrm{C}_{\mathrm{MIC}}$ e $\mathrm{N}_{\text {MIC. }}$ Os resultados das validações para $\mathrm{C} / \mathrm{N}_{\text {MIC }}$ (MATAS NIRS) e qMIC (MATAS DRIFTS) indicam que esses índices, de maior significado na avaliação ambiental do que $\mathrm{C}_{\mathrm{MIC}}$ e $\mathrm{N}_{\mathrm{MIC}}$, podem ser razoavelmente preditos por NIRS e DRIFTS. Os coeficientes de regressão foram melhores 
que os apresentados por Ludwig et al. (2002), mas os erros percentuais ainda são muito altos. As calibrações para $\mathrm{qCO}_{2}$ não foram satisfatórias.

Observa-se que DRIFTS teve melhor desempenho na modelagem dos elementos $\left(\mathrm{C}_{\mathrm{MIC}}\right.$ e $\mathrm{N}_{\mathrm{MIC}}$ ). NIRS, por sua vez, se mostrou mais adequado nas predições da respiração basal e do quociente metabólico, propriedades preditas por uma relação indireta com os espectros, através de sua correlação com o conteúdo de biomassa microbiana $\left(\mathrm{C}_{\mathrm{MIC}}\right.$ e $\left.\mathrm{N}_{\mathrm{MIC}}\right)$, com a qualidade da matéria orgânica e com a textura.

Assim, é mais vantajoso optar pela técnica DRIFTS na quantificação do carbono e do nitrogênio microbianos. A partir desses valores, o quociente microbiano e a relação $\mathrm{C} / \mathrm{N}$ microbiana podem ser calculados. Com relação à respiração basal do solo, existem métodos práticos e mais precisos que a captura de $\mathrm{CO}_{2}$ por solução alcalina, que podem trazer melhores resultados nas calibrações por DRIFTS ou, até mesmo, dispensar essa alternativa espectroscópica. A vantagem de NIRS ser sensível a este parâmetro é a possibilidade futura de uma caracterização mais ampla do solo, através de dados obtidos por satélites. 
Tabela 30 Valores medidos de referência e preditos pelos modelos CNPAF DRIFTS $\left(\mathrm{C}_{\text {MIC }}\right.$ e $\left.\mathrm{N}_{\text {MIC }}\right)$ e MATAS NIRS (C/N $\left.\mathrm{N}_{\mathrm{MIC}}\right)$

\begin{tabular}{|c|c|c|c|c|c|c|c|c|}
\hline \multicolumn{3}{|c|}{$\mathrm{C}_{\mathrm{MIC}}$} & \multicolumn{3}{|c|}{$\mathbf{N}_{\mathrm{MIC}}$} & \multicolumn{3}{|c|}{$\mathrm{C} / \mathbf{N}_{\mathrm{MIC}}$} \\
\hline Amostras & Medidos & Preditos & Amostras & Medidos & Preditos & Amostras & Medidos & Preditos \\
\hline AF11 & 240,60 & 350,34 & AF11 & 30,21 & 37,25 & AF41 & 6,29 & 5,25 \\
\hline AF12 & 152,50 & 350,34 & AF12 & 32,17 & 37,25 & AF43 & 7,59 & 5,17 \\
\hline AF31 & 242,66 & 305,96 & AF31 & 30,10 & 30,94 & PS1 & 2,53 & 2,28 \\
\hline AF35 & 303,14 & 214,84 & AF35 & 39,65 & 27,95 & PS3 & 2,00 & 2,43 \\
\hline AF36 & 341,45 & 227,31 & AF36 & 45,70 & 39,83 & PS5 & 2,21 & 3,24 \\
\hline AF39 & 288,13 & 213,40 & AF39 & 31,03 & 41,14 & PS8 & 2,08 & 3,26 \\
\hline AF41 & 614,69 & 502,91 & AF41 & 97,73 & 80,77 & PS9 & 2,10 & 3,50 \\
\hline $\mathrm{AF} 43$ & 731,04 & 457,33 & AF43 & 96,33 & 70,31 & PS12 & 1,36 & 4,03 \\
\hline $\mathrm{AF} 44$ & 165,20 & 177,47 & AF44 & 40,09 & 28,23 & PS30 & 3,15 & 2,31 \\
\hline AF45 & 165,36 & 170,91 & AF45 & 22,08 & 41,01 & PS35 & 2,75 & 4,22 \\
\hline AF46 & 185,14 & 186,22 & AF46 & 34,71 & 46,69 & PS41 & 3,85 & 3,85 \\
\hline AF67 & 546,15 & 451,07 & AF67 & 87,78 & 105,73 & AF64 & 11,77 & 5,64 \\
\hline AF68 & 403,13 & 601,65 & AF68 & 66,04 & 110,59 & AF67 & 6,22 & 6,71 \\
\hline AF69 & 551,88 & 667,63 & AF69 & 89,32 & 113,54 & AF70 & 5,61 & 5,67 \\
\hline AF71 & 382,26 & 566,58 & AF71 & 70,08 & 91,55 & AF73 & 14,75 & 4,90 \\
\hline AF72 & 274,38 & 506,76 & AF72 & 64,02 & 93,81 & - & - & - \\
\hline AF73 & 497,39 & 439,98 & AF73 & 33,73 & 86,83 & - & - & - \\
\hline AF79 & 280,99 & 350,66 & AF79 & 30,87 & 56,85 & - & - & - \\
\hline AF80 & 79,58 & 461,60 & AF80 & 43,17 & 35,95 & - & - & - \\
\hline AF81 & 205,35 & 382,51 & AF81 & 40,00 & 33,27 & - & - & - \\
\hline AF82 & 247,51 & 325,73 & AF82 & 30,62 & 20,05 & - & - & - \\
\hline AF83 & 426,21 & 201,85 & AF83 & 96,08 & 81,38 & - & - & - \\
\hline AF102 & 277,90 & 127,21 & AF102 & 58,78 & 66,48 & - & - & - \\
\hline AF107 & 300,65 & 260,58 & AF107 & 54,29 & 53,37 & - & - & - \\
\hline AF109 & 434,28 & 392,93 & AF109 & 81,66 & 81,84 & - & - & - \\
\hline
\end{tabular}



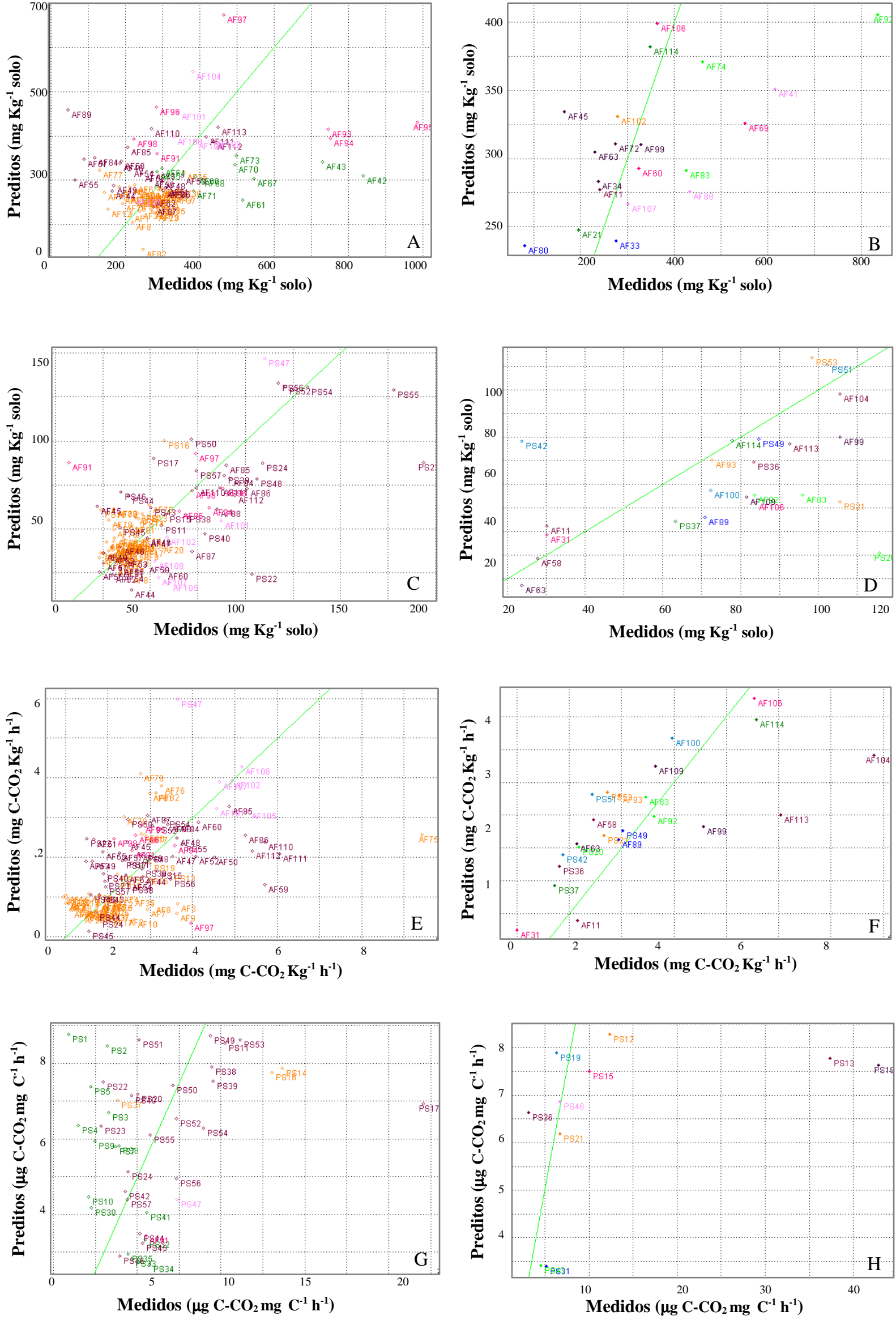

Continua... 
...continua figura anterior

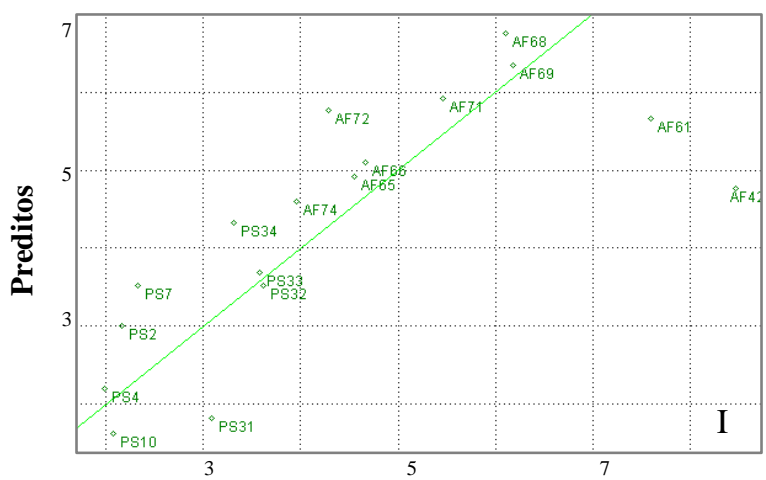

Medidos

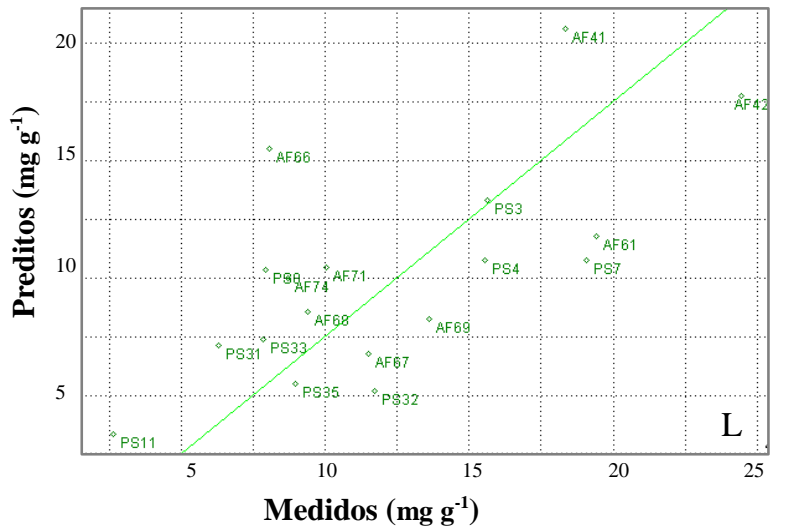

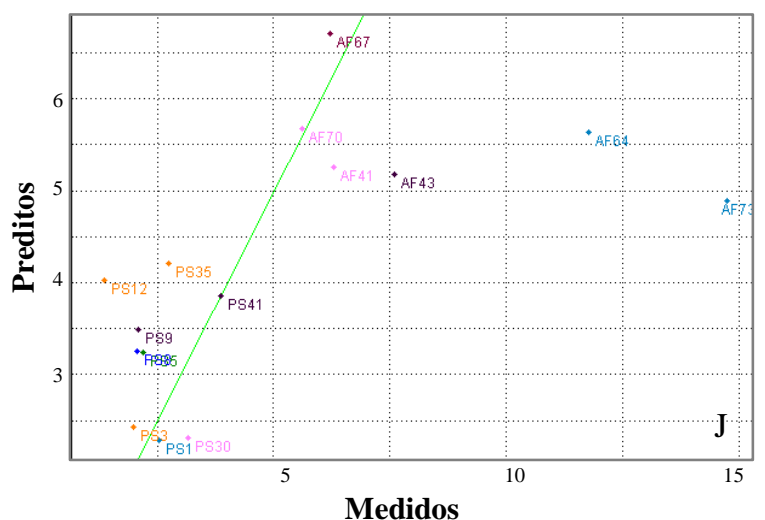

Medidos

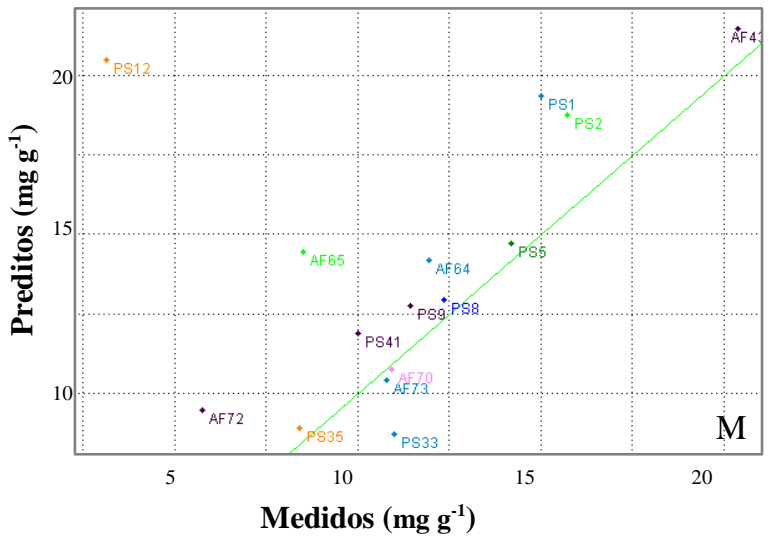

Figura 41 Gráficos dos valores medidos (de referência) versus valores preditos por modelos calculados com dados de NIRS, resultantes da validação cruzada (A, C, E, G, I) e da validação externa (B, D, F, H, J). (A) e (B) $\mathrm{C}_{\text {MIC }}$ pelo modelo

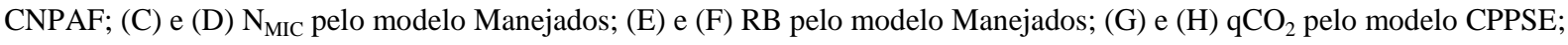
(I) e (J) $\mathrm{CN}_{\text {MIC }}$ pelo modelo MATAS; (L) e (M) qMIC pelo modelo MATAS. As linhas indicam valores 1:1. 

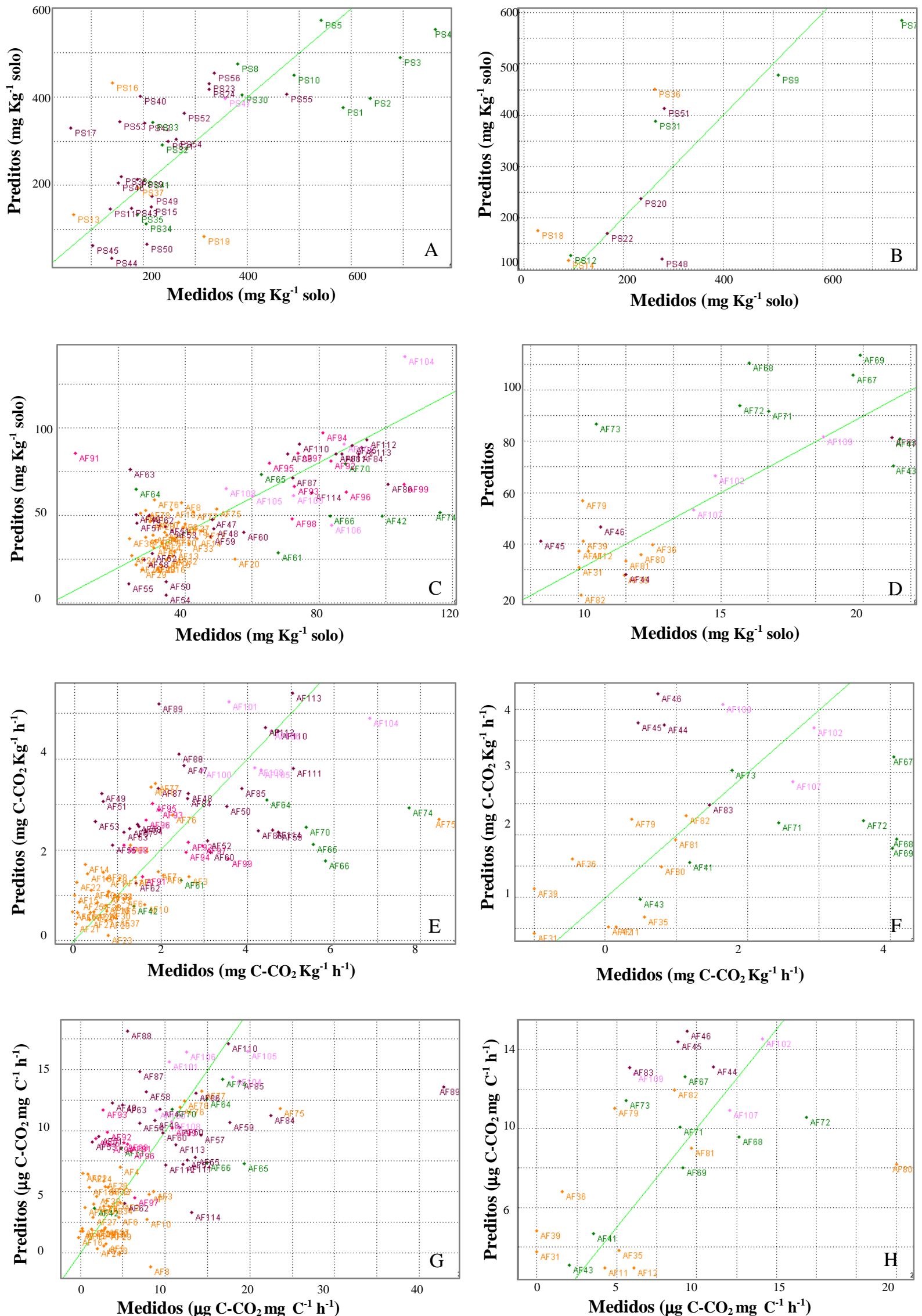

Continua.. 
...continua figura anterior
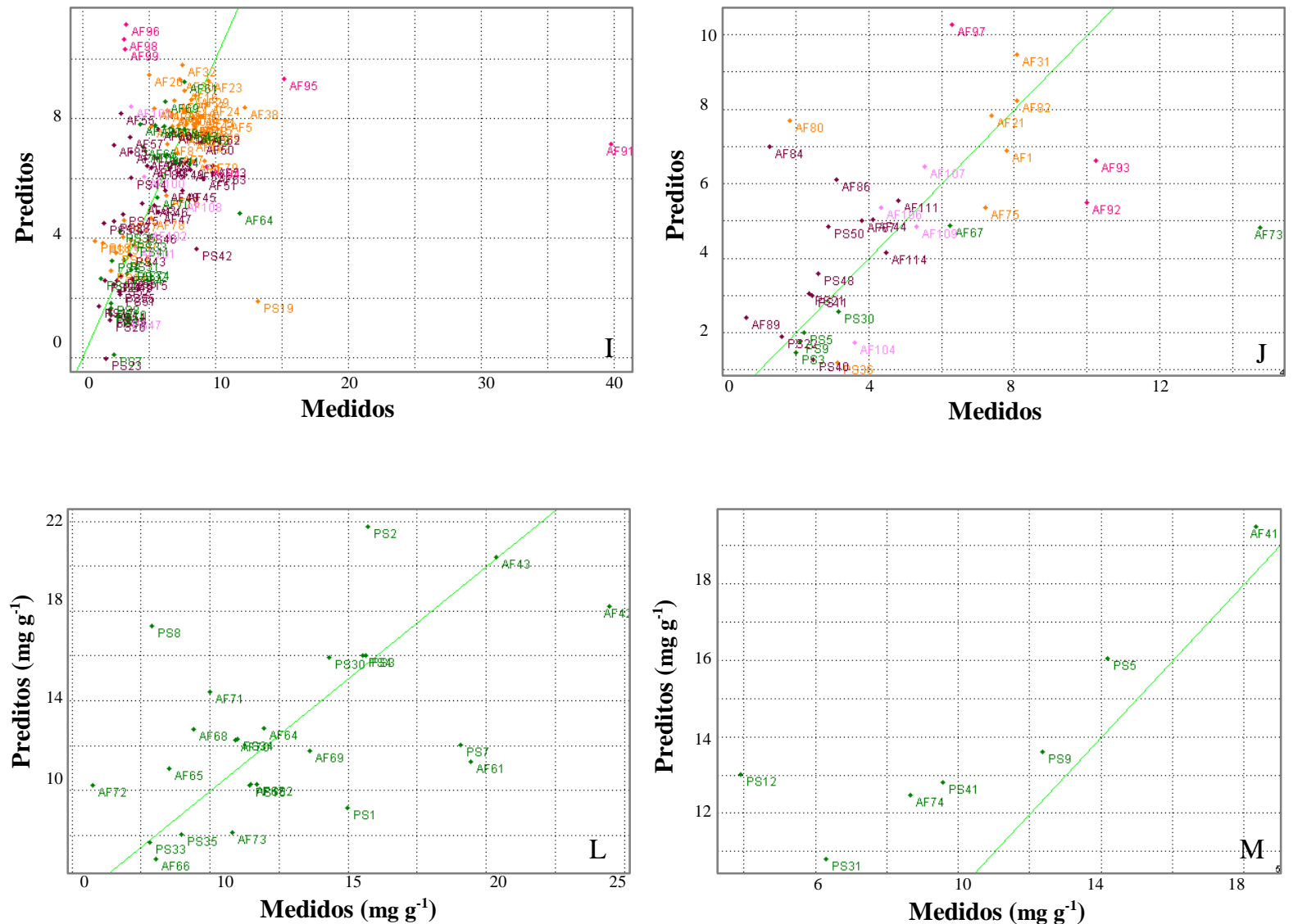

Figura 42 Gráficos dos valores medidos (de referência) versus valores preditos por modelos calculados com dados de NIRS, resultantes da validação cruzada (A, C, E, G, I, L) e da validação externa (B, D, F, H, J). (A) e (B) $\mathrm{C}_{\mathrm{MIC}}$ pelo modelo CNPAF; (C) e (D) N $\mathrm{N}_{\text {MIC }}$ pelo modelo Manejados; (E) e (F) RB pelo modelo Manejados; (G) e (H) $\mathrm{qCO}_{2}$ pelo modelo CPPSE; (I) e (J) $\mathrm{CN}_{\text {MIC }}$ pelo modelo MATAS; (L) e (M) qMIC pelo modelo MATAS. As linhas indicam valores 1:1. 


\section{CONCLUSÕES}

Observa-se que, dentre as técnicas utilizadas para análise de solo, a espectroscopia se mostrou mais sensível às diferenças entre solos de classes distintas. Tanto NIRS quanto DRIFTS identificaram bem os locais de coleta e, razoavelmente, os usos do solo e a textura.

Os diferentes locais de coleta dos solos, assim como o uso destes com culturas, pastagens ou preservação, foram características que distinguiram as amostras na análise de componentes principais. A textura não foi uma classificação que explicou bem a dispersão das amostras.

A calibração de subgrupos amostrais segundo local e uso do solo em geral melhorou a precisão dos modelos, tendo em vista o destaque dos modelos CNPAF DRIFTS e MATAS NIRS, na predição de matéria orgânica, biomassa microbiana e textura.

Na análise elementar, as quantificações de CT e NT têm a mesma precisão resultando em calibrações semelhantes. A abundância de CT no solo é compensada pela especificidade de algumas bandas a NT (bandas de amida I e amida II), que não são tão mascaradas pelos sinais de componentes minerais de solo.

Os coeficientes de regressão encontrados para as propriedades argila, silte, areia, COT, $\mathrm{C}_{\text {MIC }}$ e qMIC se enquadram na categoria $\mathrm{A}(0,8<\mathrm{r}<1,0)$ proposta por Chang et al. (2001), indicando que esses atributos podem ser acuradamente quantificados pela espectroscopia. As predições de $\mathrm{C} / \mathrm{N}$ total, $\mathrm{N}_{\mathrm{MIC}}, \mathrm{C} / \mathrm{N}_{\mathrm{MIC}}$ e $\mathrm{RB}$ se enquadraram na categoria $\mathrm{B}(0,5<\mathrm{r}<0,8)$ e podem ser melhoradas utilizando-se estratégias de calibração, entretanto aquelas classificadas como $\mathrm{C}\left(\mathrm{CT}, \mathrm{NT}\right.$ e $\left.\mathrm{qCO}_{2}\right)$ podem não ser confiáveis devido a algum erro analítico no procedimento padrão ou pelo alto desvio inerente ao método utilizado como referência.

As predições por DRIFTS foram, em geral, melhores que aquelas com calibrações em NIRS, provavelmente, devido à maior quantidade de informação disponível nesses espectros e pela maior intensidades dos sinais. 


\section{APLICAÇÕES DA ESPECTROSCOPIA NO INFRAVERMELHO}

Os modelos construídos para textura mostraram-se robustos, alcançando bons resultados com todos os solos. Estes cálculos podem ser aplicados para solos arenosos até muito argilosos, sendo provável o sucesso com solos de diversas regiões do país.

O destaque para o modelo CNPAF DRIFTS na quantificação de matéria orgânica e biomassa microbiana sugere grande potencial de uso da espectroscopia no estudo das mudanças climáticas e estoques de carbono no solo. A utilização de solos de mesma textura nas calibrações se mostra promissora para a melhoria da precisão dessas quantificações por DRIFTS.

O uso da espectroscopia resulta em economia de tempo e custo. Enquanto as determinações de textura e matéria orgânica demoram, em média, 3 horas por amostra e o procedimento convencional para biomassa microbiana, um período de 9 dias, a espectroscopia fornece tais dados em 2 minutos.

O custo da análise espectroscópica está concentrado na aquisição do equipamento, que pode ser facilmente compensado considerando-se a economia de aproximadamente $\mathrm{R} \$ 9,00$ por amostra, em relação às análises convencionais. Estas envolvem a compra de reagentes químicos, tanto para a análise quanto para o tratamento dos resíduos.

O procedimento alternativo implicaria somente na secagem e moagem do solo, havendo estudos no sentido de eliminar por completo o preparo da amostra, utilizando-se o solo úmido e sem moagem (Terhoeven-Urselmans et al., 2008). Tais estudos mostram a tendência de se analisar amostras ambientais na forma mais próxima da original.

A espectroscopia se constitui, portanto, em método confiável, pois os espectros refletem a constituição química da amostra, de maneira que os sinais observados também indicam o estado da amostra, com grande sensibilidade. 


\section{TRABALHOS FUTUROS}

Existem diversas formas de avaliar os resultados gerados neste trabalho, que durante o curto período do mestrado não puderam ser realizadas. Os procedimentos que podem ser aplicados no intuito de melhorar as calibrações são:

a) Seleção e utilização das regiões mais informativas para cada propriedade a ser predita;

b) Atualização constante da base de dados;

c) Calibração através de redes neurais;

d) Agrupamento das amostras segundo a textura para posterior calibração;

e) Agrupamento das amostras segundo a taxonomia para posterior calibração;

f) Utilização de número de amostras de validação maior do que número de amostras de calibração, no caso de um grande universo amostral com mais de 700 amostras;

g) Seleção de métodos de referência com alta precisão, de preferência validados, e utilização de ambientes com temperatura e umidade controladas;

h) Predição de classes, utilizando-se índices de qualidade de solo e métodos estatísticos como PLS-DA. 


\section{REFERÊNCIAS}

AICHI, H.; FOUAD, Y.; WALTER, C. ; VISCARRA-ROSSEL, R. A. ; CHABAANE, Z. L. ; SANAA, M. Regional predictions of soil organic carbon content from spectral reflectance measurements. Biosystems engineering, v. 104, p. 442-446, 2009.

ALVARENGA, M. I. N.; SIQUEIRA, J. O.; DAVIDE, A. C. Teor de carbono, biomassa microbiana, agregação e micorriza em solos de cerrado com diferentes usos. Ciência e Agrotecnologia, v. 23, n. 3, p. 617-625, 1999.

ANDERSON, J.P.E.; DOMSCH, K.H. A physiological method for the quantitative measurement of microbial biomass in soils. Soil Biology and Biochemistry, v. 10, n. 3, p. 215-221, 1978.

ANDERSON, T. H.; DOMSCH, K.H. The metabolic quotient for $\mathrm{CO}_{2}\left(\mathrm{qCO}_{2}\right)$ as a specific activity parameter to assess the effects of environment conditions, such as $\mathrm{pH}$, on the microbial biomass of forest soils. Soil Biology and Biochemistry, v. 25, p. 393-395, 1993.

ANJOS, L. H. C.; PEREIRA, M. G.; FONTANA, A. Matéria orgânica e pedogênese. In: SANTOS, G.de A.; CAMARGO, F.A.de O. (Ed.) Fundamentos da matéria orgânica do solo: ecossistemas tropicais e subtropicais. Porto Alegre: Metrópole, 2008. p. 65-86.

BALDOCK, J. A.; NELSON, P. N. Soil organic matter. In: SUMMER, M. E. (Ed.) Handbook of soil science. Flórida: CRC, 1999. Seção B, cap. 2, p. B-37.

BALOTA, E.L.; COLOZZI-FILHO, A.; ANDRADE, D.S.; HUNGRIA, M. Biomassa microbiana e sua atividade em solos sob diferentes sistemas de preparo e sucessão de culturas. Revista Brasileira de Ciência do solo, v. 22, p. 641-649, 1998.

BARBOSA, L. C. A. Espectroscopia no infravermelho: na caracterização de compostos orgânicos. Viçosa: Editora da Universidade Federal de Viçosa, 2007. 189p.

BAYER, C; MIELNICZUK, J. Dinâmica e função da Matéria orgânica. In: In: SANTOS, G.de A.; CAMARGO, F.A.de O. (Ed.) Fundamentos da matéria orgânica do solo: ecossistemas tropicais e subtropicais. Porto Alegre: Metrópole, 2008. p. 7-18.

BEEBE, K. R.; PELL, R. J.; SEASHOLTZ, M. B. Chemometrics: a practical guide. New York: John Wiley, 1998, p. 46-47.

BEN-DOR, E.; BANIN, A. Near-Infrared analysis as a rapid method to simultaneously evaluate several soil properties. Soil Science Society of America Journal, v. 59, p. 364-372, 1995.

BLANCO, M.; COELHO, J.; ITURRIAGA, H.; MASPOCH, S.; BERTARN, E. Simultaneous determination of rubber additives by FT-IR Spectrophoyometry with multivariate calibration. Applied Spectroscopy, v.49, p.747-753, 1995.

BOLIN, B.; COOK, R. B. C, N, P and S Cycles: Major reservoirs and fluxes. In: BOLIN, B.; COOK, R. B. The major biogeochemical cycles and their interactions. New York: John Wiley, 1983. Disponível em: <http://www.icsu-scope.org/downloadpubs/scope21/chapter02.html>. Acesso em: 02 jan. 2010.

BOT, A.; BENITES, J. The importance of soil organic matter: key to drought-resistant soil and sustained food production. Roma: Food and agriculture organization of the united nations (FAO), 2005, 93p. (FAO soils bulletin, 80). 
BROADBENT, F.E. The soil organic fraction. Advances in Agrononomy, v. 5, p. 153-183, 1953.

CAMARGO, F. A. O.; SILVA, L. S.; GIANELLO, C.; TEDESCO, M. J.; VIDOR, C. Nitrogênio orgânico do solo. In: SANTOS, G.de A.; CAMARGO, F.A.de O. (Eds.) Fundamentos da matéria orgânica do solo: ecossistemas tropicais e subtropicais. Porto Alegre: Metrópole, 2008. p. 87-100.

CAMPBELL, C. A.; BIEDERBECK,V.O.; ZENTNER, R. P.; LAFOND, G. P. Effect of crop rotations and cultural practices on siol organic matter, microbial biomass and respiration in a thin Black Chernozem. Canadian Journal of Soil Science, v. 71, p. 363-376, 1991.

CANELLAS, L. P. Distribuição da matéria orgânica e características de ácidos húmicos em solos com adição de resíduos de origem urbana. Pesquisa Agropecuária Brasileira, v. 36, n. 12, p. 1529-1538, 2001.

CANELLAS, L. P.; MENDONÇA, E. S.; DOBBSS, L. B.; BALDOTTO, M. A.; VELOSO A. C. X.; SANTOS, G. A.; AMARAL SOBRINHO, N. M. B. Reações da matéria orgânica. In: SANTOS, G.de A.; CAMARGO, F.A.de O. (Ed.) Fundamentos da matéria orgânica do solo: ecossistemas tropicais e subtropicais. Porto Alegre: Metrópole, 2008. p. 45-61.

CARDOSO, M.O. Métodos para quantificação da biomassa microbiana do solo. Agropecuária Técnica, v. 25, n. 1, p. 1-12, 2004.

CARVALHO, F. Atributos bioquímicos como indicadores da qualidade do solo em florestas de Araucaria angustifólia (Bert.) O. Ktze. no estado de São Paulo. 79 f. 2005. Dissertação (Mestrado em Ecologia de Agroecossistemas). Escola Superior Luiz de Queiroz (ESALQ), Universidade de São Paulo, Piracicaba, 2005.

CERETTA, C. A.; BAYER, C.; DICK, D. P.; MARTIN-NETO, L.; COLNAGO, L. A. Métodos Espectroscópicos. In: SANTOS, G. A.; SILVA, L. S.; CANELLAS, L. P.; CAMARGO, F. A. O. (Ed.) Fundamentos da matéria orgânica do solo: ecossistemas tropicais e subtropicais, Porto Alegre: Metropole, 2008. p. 201-228.

CERRI, C.C. Conceitos básicos. 2008. Disponível em: <web.cena.usp.br/apostilas/Cerri/conceitosbasicos.ppt>. Acesso em: 26 nov. 2008.

CHANG, C.W.; LAIRD, D.A.; MAUSBACH, M.J.; HURBURGH, C.R.J. Near-Infrared Reflectance Spectroscopy-Principal Components Regression Analyses of Soil Properties. Soil Science Society of America Journal , v. 65, p. 480-490, 2001.

CHANG, C.-W., LAIRD, D.A. Near-infrared reflectance spectroscopic analysis of soil C and N. Soil Science v. 167, n. 110, p. 116, 2002.

COATES, J. Review of IR sampling methods. In: WORKMAN JÚNIOR., J.; SPRINSTEEN, A. (Ed.) Applied spectroscopy: a compact reference for practitioners. San Diego: Academic Press, 1998. p49-91.

CONCEIÇÃO, M.; MANZATTO, C.V.; ARAÚJO, W.S.; MARTIN-NETO, L.; SAAB, S.C.; CUNHA, T.J.F.; FREIXO, A.A. Estudo comparativo de métodos de Determinação do teor de Matéria Orgânica em solos orgânicos do estado do Rio de Janeiro. Pesquisa em Andamento, Embrapa Solos, n. 3, p. 1-5, 1999.

COLEMAN, T. L.; AGBU, P. A.; MONTGOMERY, O. L.; GAO, T.; PRASAD, S. Spectral Band Selection for Quantifying Selected Properties in Highly Weathered Soils. Soil Science, v. 151, p. 331397, 1991. 
COÛTEAUX, M.M.; BJORN, B. ROVIRA, P. Near infrared reflectance spectroscopy for determination of organic matter fractions including microbial biomass in coniferous forest soils. Soil Biology and Biochemistry, v. 35, p. 1587-1600, 2003.

DALMOLIN, R.S.D.; GONÇALVES, C. N.; KLAMT, E.; DICK, D. P. Relação entre os constituintes do solo e seu comportamento espectral. Ciência Rural, v. 35, n. 2, p. 481-489, 2005.

DE-POLLI, H.; GUERRA, J. G. M. C, N e P na biomassa microbiana do solo. In: SANTOS, G.de A.; CAMARGO, F.A.de O. (Ed.) Fundamentos da matéria orgânica do solo: ecossistemas tropicais e subtropicais. Porto Alegre: Metrópole, 2008. p. 263-273.

DEMATTÊ, J.A.M.; CAMPOS R.C.; ALVES, M.C.; FIORIO, P.R.; NANNI; M.R. Visible-NIR reflectance: a new aproach on soil evaluation. Geoderma, v. 121, p. 95-112, 2004.

DEMATTÊ, J. A. M.; SILVA, M. L. S.; ROCHA, G. C.; CARVALHO, L.A.; FORMAGGIO, A. R.; FIRME, L. P. Variações espectrais em solos submetidos à aplicação de torta de filtro. Revista Brasileira de Ciência do Solo, v. 29, p. 317-326, 2005.

DUCKWORTH, J. H. Spectroscopic quantitative analysis. In: WORKMAN J.R.J.; SPRINSTEEN, A. (Ed.) Applied spectroscopy: a compact reference for practitioners. San Diego-USA: Academic Press, 199 p. $93-164$.

EBERHARDT, D. N.; VENDRAME, P. R. S; BECQUER, T.; GUIMARÃES, M. F. Influência da granulometria e da mineralogia sobre a retenção do fósforo em latossolos sob pastagens no cerrado. Revista Brasileira de Ciência do Solo, v. 32, p. 1009-1016, 2008.

EMBRAPA SOLOS. Manual de métodos de análise de solo. 2. ed. Rio de Janeiro: EMBRAPACNPS, 1997. 212p.

EMBRAPA SOLOS. Sistema brasileiro de classificação de solos. 2. ed. Rio de Janeiro: EMBRAPACNPS, 2006. 306p.

EMBRAPA SOLOS. Projeto carbono. Disponível em: <http://www.cnps.embrapa.br/carbono/antecedentes/antecedentes.html> Acesso em: 28 dez. 2009.

ESSINGTON, M. E. Soil and water chemistry: an integrative approach. London: CRC, 2004. 534 p.

FEIDEN, A. Agroecologia: introdução e conceitos. In: AQUINO, A. M.; ASSIS, R. L. (Ed.). Agroecologia: princípios e técnicas para uma agricultura orgânica sustentável. Brasília: Embrapa Informação Tecnológica, 2005. 517 p.

FERREIRA, M. M.; FERNANDES, B.; CURI, N. Mineralogia da fração argila e estrutura de latossolos da região sudeste do Brasil. Revista Brasileira de Ciência do Solo, v. 23, p. 507-514, 1999.

FERREIRA, J.A.; SIMÕES, M. L.; MILORI, D. M. B. P.; MARTIN-NETO, L. HAYES, M. H. B.; MAO, J. Caracterização espectroscópica da matéria orgânica do solo. São Carlos: Embrapa Instrumentação Agropecuária, 2004. 3p. (Circular Técnica, ${ }^{\circ}{ }^{24}$ ).

FILIP, Z.; HERMANN, S. An attempt to differentiate Pseudomonas spp. and other soil bacteria by FT-IR spectroscopy. European Journal of Soil Biology, v. 37, p. 137-143, 2001.

FISK, M.C.; RUETHER, K.F.; YAVITT, J.B. Microbial activity and functional composition among northern peatland ecosystems. Soil Biology and Biochemistry, v. 35, n. 4, p. 591-602, 2003. 
FORMAGGIO, A. R.; EPIPHANIO, J. C. N. Feições espectrais e parâmetros analíticos de solos tropicais brasileiros. In: SIMPÓSIO BRASILEIRO DE SENSORIAMENTO REMOTO, 10, 2001, Foz do Iguaçu, Anais. São José dos Campos: Sociedade Brasileira de Sensoriamento Remoto, 2001. p. $1399 \quad-1401 . \quad$ Disponível em: <http://marte.dpi.inpe.br/col/dpi.inpe.br/lise/2001/09.20.18.07/doc/1399.1401.221.pdf>. Acesso em 29 dez. 2009.

GAMA-RODRIGUES, E. F. Biomassa microbiana e ciclagem de nutrientes. In: SANTOS, G. A.; CAMARGO, F. A. O. (Ed.). Fundamentos da matéria orgânica: ecossistemas tropicais e subtropicais. Porto Alegre: Gênesis, 2008. p.159-168.

GERZABEK, M. H.; ANTIL, R. S.; KOGEL-KNABNER, I.; KNICKER, H.; KIRCHMANN, H. HABERHAUER, G. How are soil use and management reflected by soil organic matter characteristics: a spectroscopic approach. European Journal of Soil Science, v. 57, p. 485-494, 2006.

GRISI, B.M. Temperature increase and its effect on microbial biomass and activity of tropical and temperate soils. Revista de Microbiologia, v. 28, p. 5-10, 1997.

IBGE. Mapa de solos do Brasil, 2005. Disponível em:< http://mapas.ibge.gov.br/solos/viewer.htm>. Acesso em: 28 dez. 2009.

IBOMCHA SINGH, L.; YADAVA, P. S. Spatial distribution of microbial biomassa in relation to land-use in subtropical systems of north-east India. Tropical Ecology, v. 47, p. 63-70, 2006.

INSAM, H.; DOMSCH, K.H. Relationship between soil organic carbon and microbial biomass on chronosequences of reclamation sites. Microbial Ecology, v.15, p. 177-188, 1988.

ISLAM, K. R.; WEIL, R. R. Soil quality indicator properties in mid-Atlantic soils as influenced by conservation management. Journal of Soil and Water Conservation, v. 55, p. 69-78, 2000.

JACKSON, M.L. Analisis quimico de suelos. Barcelona: Omega, 1982. p. 282-309.

JANIK, L.J.; MERRY, R.H.; SKJEMSTAD, J.O. Can mid infra-red diffuse reflectance analysis replace soil extractions? Australian Journal of Experimental Agriculture, v. 38, n. 7, p. 681- 696, 1998.

JENKINSON, D. S.; POWLSON, D.S. The effects of biocidal treatments on metabolism in soil-I. Fumigation with chloroform. Soil Biology and Biochemistry, v. 8, p. 167-177, 1976.

JENKINSON, D. S.; LADD, J. N. Microbial biomass in soil: measurement and turnover. In: PAUL, E. A. ; LADD, J. N. Soil Biochemistry, v. 5, p. 415-473, 1981.

KIRK, J. L.; BEAUDETTE, L. A.; HART, M.; MOUTOGLIS, P.; KLIRONOMOS, J. N.; LEE, H.; TREVORS, J. T. Methods of studying soil microbial diversity. Journal of Microbiological Methods, v. 58, p. 169-188, 2004.

KOENIG, J.L. Spectroscopy of polymers. Washington: American Chemical Society, 1992. 328 p.

LAMBAIS, M. R.; CURY, J. C.; MALUCHE-BARETTA, C. R.; BULL, R. C. Diversidade microbiana do solo: definindo novos paradigmas. Tópicos em Ciência do Solo, v. 4, p. 43-84, 2005.

LEONARDO, H.C.L. Indicadores da qualidade de solo e água para a avaliação do uso sustentável da microbacia hidrográfica do rio Passo Cue, região oeste do estado do Paraná. 2003.121 f. Dissertação (Mestrado em Recursos Florestais). Escola Superior Luiz de Queiroz, Universidade de São Paulo, Piracicaba, 2003. 
LIMA, A.; CAPOBIANCO, J. P. R. Alcance territorial da legislação ambiental e a consolidação do uso agropecuário de terras no Brasil. Belém: Instituto de Pesquisa Ambiental da Amazônia, 2009. 5 p.

LIN, Q.; BROOKES, P. C. An evaluation of the substrate-induced respiration method. Soil Biology and Biochemistry, v. 31, p. 1969-1983, 1999.

LINCOLN, T.; ZEIGER, E. Fisiologia Vegetal. 4. ed., Porto Alegre: Artmed, 2009, 848 p.

LUDWIG, B.; KHANNA, P. K.; BAUHUS, J.; HOPMANS, P. Near infrared spectroscopy of forest soils to determine chemical and biological properties related to soil sustainability. Forest Ecology and Management, v. 171, p. 121-132, 2002.

MCCARTY, G. W.; REEVES III, J. B.; REEVES, V. B.; FOLLETT, R. F.; KIMBLE, J. M. Midinfrared and near-infrared diffuse reflectance spectroscopy for soil carbon measurement. Soil Science Society of America Journal v. 66, p. 640-646, 2002.

MADARI, B. E.; REEVES III, J. B.; COELHO, M.R.; MACHADO, P.L.O.A.; DE-POLLI, H.; COELHO, R.M.; BENITES, V.M.; SOUZA, L.F.; MCCARTY, G.W. Mid- and Near-infrared Spectroscopic Determination of Carbon in a Diverse Set of Soils from the Brazilian National Soil Collection. Spectroscopy Letters, v. 38, p. 721-740. 2005.

MADARI, B. E.; REEVES, J. B.; MACHADO, P. O. A.; GUIMARÃES, C. M.; TORRES, E.; McCARTY, G.W. Mid- and near-infrared spectroscopic assessment of soil compositional parameters and structural indices in two Ferrasols. Geoderma,v. 136, p. 1-15, 2006a.

MADARI, B. E.; REEVES III, J. B.; COELHO, M. R.; MACHADO, P. L. O. A.; DE-POLLI, H.; COELHO, R. M.; BENITES, V. M.; SOUZA, L. F.; McCARTY, G. W. Espectroscopia infravermelha para a determinação de carbono do solo: Perspectiva de um método economicamente viável e ambientalmente seguro. Santo Antônio de Goiás: Embrapa Arroz e Feijão, 2006b. 6 p. (Comunicado Técnico, 126).

MADARI, B. E.; REEVES III, J. B. Espectroscopia no infravermelho aplicada à análise qualitativa e quantitativa de solos e plantas. In: ENCONTRO SOBRE METODOLOGIAS DA EMBRAPA, 23., 2008, Belém. Disponível em: <http://xiiimet.cpatu.embrapa.br/arquivos/Minicurso\%20$\% 20$ Espectroscopia\%20no\%20Infravermelho\%20Aplicada\%20a\%20Analise.pdf $>$. Acesso em: 02 jan. 2010.

MARCOLIN, C.D. Propriedades físicas de nitossolo e latossolos argilosos sob plantio direto. 2006. 110 f. Dissertação (Mestrado em Agronomia) - Universidade de Passo Fundo, Passo Fundo, 2006.

MARK, H.; WORKMAN, J. Statistics in spectroscopy. 2. ed. San Diego: Academic Press, 2003. 328 p.

MARTIN-NETO, L.; MILORI, D.M.B.P; DA SILVA, W.T.L. (Ed.) Humic substances in the soil and water environment. São Carlos: Embrapa/Rima, 2004. v. 1.

MESSERSCHMIDT, I. Análise quantitativa por espectroscopia no infrafermelho médio empregando técnicas de refletância e calibração multivariada. 1999. 138 f. Tese (Doutorado em Química). Instituto de Química, Universidade Estadual de Campinas, Campinas, 1999.

MITTELMANN, A.; SOBRINHO, F.S.; OLIVEIRA, J.S.; FERNANDES, S.B.V.; LAJÚS, C.A.; MIRANDA, M.; ZANATTA, J.C.; MOLETTA, J.L. Avaliação de híbridos comerciais de milho para utilização como silagem na Região Sul do Brasil. Ciência Rural, v. 35 n. 3, p. 684-690, 2005. 
MOREIRA, F. M. S.; SIQUEIRA, J. O. Microbiologia e bioquímica do solo. 2. ed. Lavras: Editora UFLA, 2006. 729 p.

MOREIRA, A.; MALAVOLTA, E. Dinâmica da matéria orgânica e da biomassa microbiana em solo submetido a diferentes sistemas de manejo na Amazônia Ocidental. Pesquisa Agropecuária Brasileira, v. 39, n.11, p. 1103-1110, 2004.

MORGAN, C .L. S.; WAISER, T. H.; BROWN, D. J.; HALLMARK, C. T. Simulated in situ characterization of soil organic and inorganic carbon with visible near-infrared diffuse reflectance spectroscopy. Geoderma, v. 151, p. 249-256, 2009.

NAES, T.; ISAKSSON, T.; FEARN, T.; DAVIES, T. A user friendly guide to multivariate calibration and classification. Chichester: NIR Publications, 2002. 344 p.

NAUMANN, D., SCHULTZ, C. P., HELM, D. What can infrared spectroscopy tell us about structure and composition of intact bacterial cells? In: MANTSCH, H. H., CHAPMANN, D. (Ed.) Infrared Spectroscopy of biomolecules. New York: Wiley-Liss, 1996. 359 p.

NELSON, D. W.; SOMMERS, L. E. Total carbon, organic carbon and organic matter. In: SPARKS, D. L. Methods of soil analysis. Madison: Soil Science Society of America and American Society of Agronomy, 1996. Pte. 3. p. 963-1010. (Chemical Methods-SSSA Book Series, 5).

NIEMEYER, J.; CHEN, Y.; BOLLAG, J.M. Characterization of humic acids, composts and peat by diffuse reflectance Fourier-transform infrared spectroscopy. Soil Science Society of America Journal, v. 56, p. 130-135, 1992.

NOGUEIRA, A. R.; SOUZA, G. B.; BATISTA, L. A. R. Determinação espectrofotométrica de nitrogênio em digeridos de plantas em sistema de análise por injeção em fluxo. Química Nova, v. 19, p. 1, 1996.

OLENDZKI, R.N. Caracterização das interações de substâncias húmicas com a matéria inorgânica em solos de cultivo de arroz irrigado: contribuição à aquisição de dados essenciais para avaliação global do sequestro de carbono no solo. 2006. 134 f. Tese (Doutorado em Química) Universidade Federal do Paraná, Curitiba, 2006.

OSIRO, D.; COLETA-FILHO, H. D.; MACHADO, M.A.; COLNAGO, L.A. Uso de FTIR par a análise de bactérias causadoras do cancro cítrico e CVC. São Carlos: Embrapa Instrumentação Agropecuária, 2000. 5 p. (Comunicado Técnico, 40).

PALMBORG, C.; NORDGREN, A. Modelling microbial activity and biomass in forest soil with substrate quality measured using near infrared reflectance spectroscopy. Soil Biology and Biochemistry, v. 25, n. 12, p. 1713-1718, 1993.

PREVEDELLO, C. L. Física do solo: com problemas resolvidos. Curitiba: SAEAFS, 1996. 446p.

PRIMAVESI, O.; PRIMAVESI, A. C. P. A.; PEDROSO, A. F.; CAMARGO, A. C.; RASSINI, J. B.; ROCHA-FILHO, J.; OLIVEIRA, G. P.; CORREA, L. A.; ARMELIN, M. J. A.; VIEIRA, S. R.; DECHEN, S. C. F. Microbacia hidrográfica do ribeirão Canchin: um modelo real de laboratório ambiental. São Carlos:Embrapa Pecuária Sudeste, 1999. 133 p. (Boletim de Pesquisa n.5).

REEVES III, J.B.; McCARTY, G.W. Quantitative analysis of agricultural soils using near infrared reflectance spectroscopy and fibre-optic probe. Journal of Near Infrared Spectroscopy v. 9, p. 2534, 2001. 
REEVES III, J.B. Mid-infrared diffuse reflectance spectroscopy: Is sample dilution with $\mathrm{KBr}$ necessary, and if so, when. American Laboratory, v. 35 n. 8, p. 24-28, 2003.

REEVES, J. B.; FRANCIS B. A; HAMILTON S. K. Specular reflection and diffuse reflectance spectroscopy of soils. Applied Spectroscopy, v. 59, p. 39-46, 2005.

RESCK, D. V. S.; FERREIRA, E. A. B.; FIGUEIREDO, C. C.; ZINN, Y. L. Dinâmica da matéria orgânica no Cerrado. In: SANTOS, G.de A.; CAMARGO, F.A.de O. (Ed.) Fundamentos da matéria orgânica do solo: ecossistemas tropicais e subtropicais. Porto Alegre: Metrópole, 2008. p. 359-406.

RINNAN, R.; RINNAN, A. Application of near infrared reflectance (NIR) and fluorescence spectroscopy to analysis of microbiological and chemical properties of artic soil. Soil Biology and Biochemistry, v. 39, p. 1664-1673, 2007.

RODRIGUES, R. Ex-ministro da Agricultura, 2009. Disponível em:

$<$ http://www.bbc.co.uk/portuguese/noticias/2009/03/090331_brasil_agricultura_ac.shtml>. Acesso em: 29 dez. 2009.

RUSSELL, J. D.; FRASER, A. R. Infrared methods. In: WILSON, M. J. (Ed.) Clay mineralogy: spectroscopy and chemical determinative methods. London: Chapman e Hall, 1994. cap. 2.

SCHUMACHER, B. A. Methods for the determination of total organic carbon (TOC) in soils and sediments. United States Environmental Protection Agency, Environmental Sciences Division, National Exposure Research Laboratory, Las Vegas, 2002. Disponível em: <http://www.epa.gov/esd/cmb/research/papers/bs116.pdf>. Acesso: 02 jan. 2010.

SEGNINI, A. Estrutura e estabilidade da matéria orgânica em áreas com potencial de seqüestro de carbono do solo. 2007. $131 \mathrm{f}$. Tese (Doutorado em Química Analítica), Instituto de Química de São Carlos, Universidade de São Paulo, São Carlos, 2007.

SEGNINI, A.; dos SANTOS, L.M.; da SILVA, W.T.L.; MARTIN-NETO, L.; BORATO, C.E.; MELO, W.J.; BOLONHEZI, D. Estudo comparativo de métodos para a determinação da concentração de carbono em solos com altos teores de Fe (Latossolos). Química Nova, v. 31, n. 1, p. 94-97, 2008.

SENA, M. M.; POPPI, R. J.; FRIGHETTO, R. T. S.; VALARINI, P. J. Avaliação do uso de métodos quimiométricos em análise de solos. Química Nova, v. 23, n. 4, p. 547-556, 2000.

SHENK, J.S.; WESTERHAUS, M.O. The application of near infrared spectroscopy (NIRS) to forage analysis. In: FAHEY, G.C.; MOSSER, L.E.; MERTENS, D.R.; COLLINS, M. (Ed.) Proceedings of the National conference on Forage Quality Evaluation and Utilization. Madison: American Society of Agronomy, 1994. p. 406-449.

SILVA, A. C.; TORRADO, P. D.; ABREU JUNIOR, J. S. Métodos de quantificação da matéria orgânica do solo. Revista da Universidade de Alfenas, v. 5, p. 21-26, 1999.

SILVERSTEIN, R. M.; WEBSTER, F. X.; KIEMLE, D. J. Identificação espectrométrica de compostos orgânicos. 7. ed.Tradução de Ricardo Bicca de Alencastro. Rio de Janeiro: LTC, 2007. $490 \mathrm{p}$.

SMITH, B. C. Fundamentals of Fourier transform infrared spectroscopy. Bota Raton: CRC Press, 1996. $202 \mathrm{p}$.

SOUZA, E. D.; CARNEIRO, M.A.C.; BARBOSA, H.P.; SILVA, C.A.; BUZZETTI, S. Frações do carbono orgânico, biomassa e atividade microbiana em um Latossolo Vermelho sob cerrado 
submetido a diferentes sistemas de manejos e usos do solo. Acta Scientiarium Agronomy, v. 28, n. 3, p. 323-329, 2006.

SPARLING, G.P.; ROSS, D.J. Biochemical methods to estimate soil microbial biomass: current development and applications. In: MULUNGOY, K.; MERCKX, R. (Ed.). Soil organic matter dynamics and sustainability of tropical agriculture. Leuven: Willey- Sayce, 1993. p. 21-37.

TABATABAI, M.A. Soil organic matter testing: an overview. In: TABATABAI, M.A. Soil organic matter: analysis and interpretation. Madison: SSSA, 1996. p. 1-9. (SSSA Special Publication, 46).

TERHOEVEN-URSELMANS, T., SCHMIDT, H.; JOERGENSEN, R. G.; LUDWIG, B. Usefulness of near-infrared spectroscopy to determine biological and chemical soil properties: Importance of sample pre-treatment. Soil Biology and Biochemistry, v. 40, p. 1178-1188, 2008.

TERRA-FILHO, M.; SATOSHI, K. Câncer pleuropulmonar ocupacional. Jornal Brasileiro de Pneumologia, v. 32 (Supl 2), p. 78-86, 2006.

VANCE, E.D.; BROOKES, P.C.; JENKINSON, D.S. An extraction method for measuring soil microbial biomass. Soil Biology and Biochemistry, v. 19, p. 703-707, 1987a.

VANCE, E. D.; BROOKES, P. C.; JENKINSON, D. S. Microbial biomass measurements in forests soils: the use of the chloroform fumigation-incubation method in strongly acid soils. Soil Biology and Biochemistry, v. 19, p. 697-702, 1987b.

VERGNOUX, A.; DUPUY, N.; GUILIANO, M.; VENNETIER, M.; THÉRAULAZ, F. ; DOUMENQ, P. Fire Impact on forest soils evaluated using near-infrared spectroscopy and multivariate calibration. Talanta, v. 80, p. 39-47, 2009.

VISCARRA-ROSSEL, R.A.; WALVOORT, T.D.J.J.; MCBRATNEY, A.B.; JANIK, L.J.; SKJEMSTAD, J.O. Visible, near infrared, mid infrared or combined diffuse reflectance spectroscopy for simultaneous assessment of various soil properties. Geoderma, v. 131, p. 59-75, 2006.

WARDLE, D.A. Metodologia para quantificação da biomassa microbiana do solo In: HUNGRIA, M.; ARAÚJO, R.S. (Ed.) Manual de métodos empregados em estudos de microbiologia agrícola. Santo Antônio de Goiás: Embrapa Arroz e Feijão, 1994. 542 p. (Documentos, 46).

WESTAD, F.; SCHMIDT, A.; KERMIT, M. Incorporating band-assignment in near infrared spectroscopy regression models. Journal of Near Infrared Spectroscopy, v. 16, p. 265-273, 2008.

WILLIAMS. P.; NORRIS, K. Near-infrared Technology in the Agricultural and Food Industries. 2. ed. St. Paul: American Association of Cereal Chemists, 2001. 312 p.

WHIFFEN, D. H. Spectroscopy. 2. ed. New York: John Wiley and Sons, 197. 206 p.

WORKMAN, J. R. Optical Spectrometers. In: WORKMAN J. R., J.; SPRINSTEEN, A. (Ed.) Applied spectroscopy: a compact reference for practitioners. San Diego: Academic Press, 1998. p. 4-91. 
ANEXO I

Mapa de solos do Brasil. Fonte: IBGE, 2005.

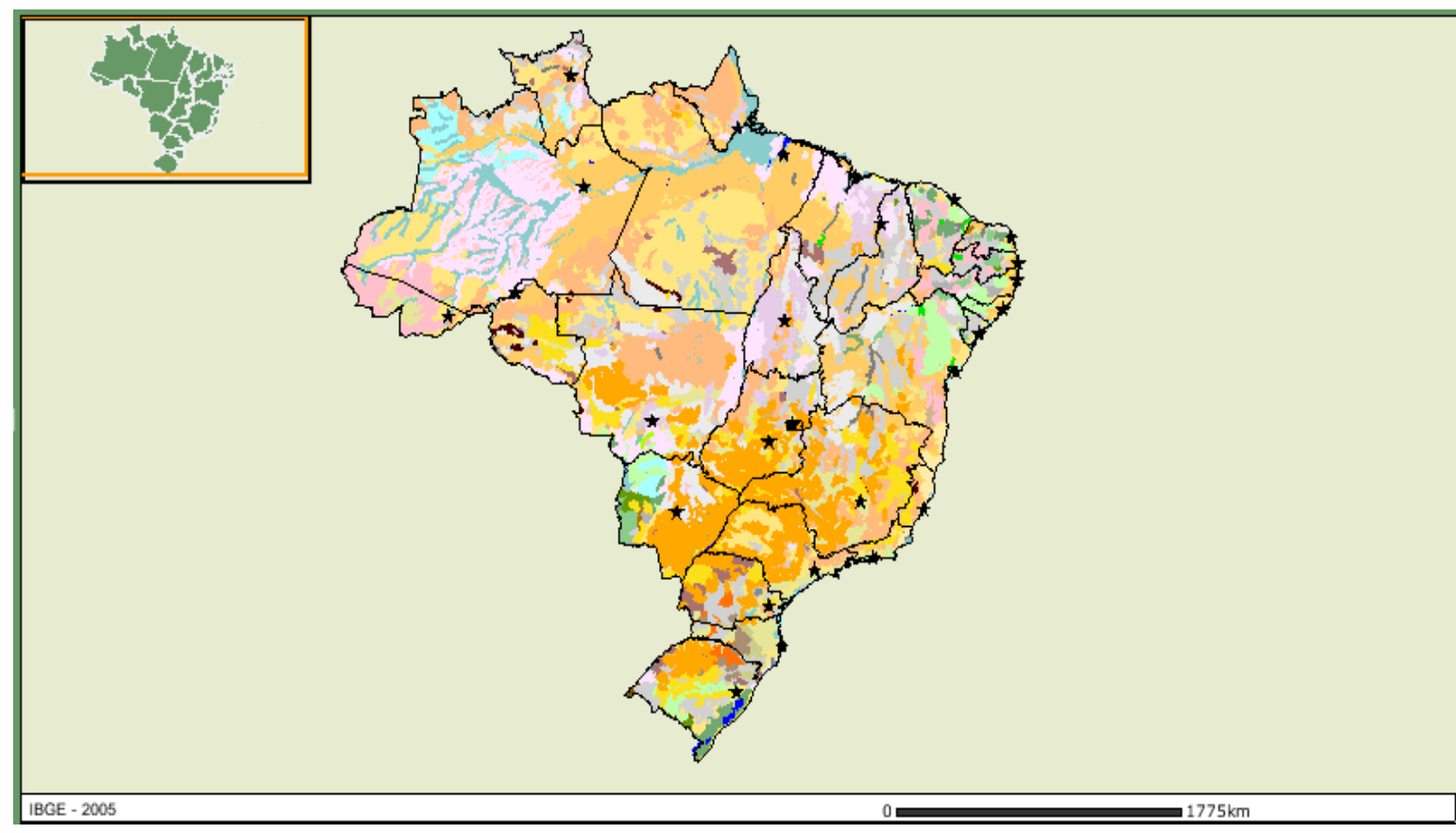

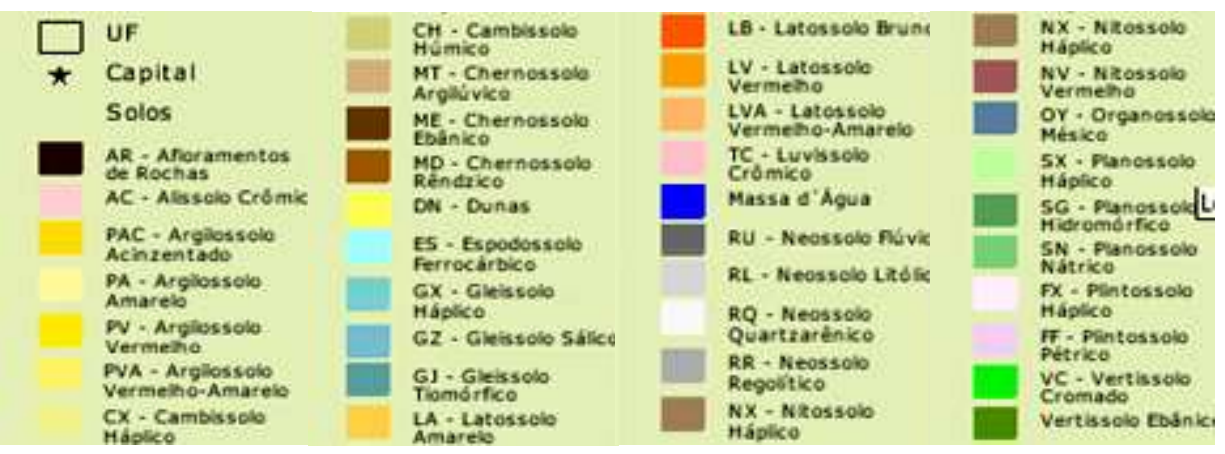




\section{ANEXO II}

Resultados de validação cruzada e validação externa referentes aos modelos de calibração em NIRS para o grupo amostral TODOS sem transformação dos dados e com a $1^{\mathrm{a}}$ e $2^{\mathrm{a}}$ derivadas

\begin{tabular}{|c|c|c|c|c|c|c|c|c|}
\hline & Transformação & RVC & SEV & $n^{\circ}$ de fatores & Intecepto & Inclinação & RVE & Erro (\%) \\
\hline $\mathrm{C}_{\mathrm{MIC}}$ & $\mathrm{d}_{0}$ & 0,6065 & 127,51 & 7 & 146,28 & 0,59 & 0,8297 & 47,87 \\
\hline $\mathrm{C}_{\mathrm{MIC}}$ & $\mathrm{d}_{1}$ & 0,3711 & 161,53 & 6 & 172,80 & 0,50 & 0,7544 & 59,48 \\
\hline $\mathrm{C}_{\mathrm{MIC}}$ & $\mathrm{d}_{2}$ & 0,1898 & 155,19 & 2 & 304,98 & & 0,0145 & 73,04 \\
\hline $\mathrm{N}_{\mathrm{MIC}}$ & $\mathrm{d}_{0}$ & 0,7350 & 51,09 & 7 & 16,34 & 0,74 & 0,9212 & 34,38 \\
\hline $\mathrm{N}_{\mathrm{MIC}}$ & $\mathrm{d}_{1}$ & 0,5906 & 61,63 & 4 & 32,46 & 0,55 & 0,7873 & 40,91 \\
\hline $\mathrm{N}_{\mathrm{MIC}}$ & $\mathrm{d}_{2}$ & 0,4707 & 67,19 & 3 & 50,75 & & 0,4925 & 51,66 \\
\hline $\mathrm{RB}$ & $\mathrm{d}_{0}$ & 0,4040 & 0,67 & 8 & 1,09 & 0,22 & 0,4538 & 106,82 \\
\hline $\mathrm{RB}$ & $\mathrm{d}_{1}$ & 0,4433 & 0,64 & 6 & 0,84 & 0,56 & 0,7572 & 61,64 \\
\hline $\mathrm{RB}$ & $\mathrm{d}_{2}$ & 0,3882 & 0,67 & 5 & 1,09 & & 0,4133 & 80,45 \\
\hline $\mathrm{qCO}_{2}$ & $\mathrm{~d}_{0}$ & 0,3469 & 6,35 & 6 & 4,03 & 0,45 & 0,6209 & 118,69 \\
\hline $\mathrm{qCO}_{2}$ & $\mathrm{~d}_{1}$ & 0,3710 & 6,50 & 6 & 4,57 & 0,34 & 0,4150 & 131,96 \\
\hline $\mathrm{qCO}_{2}$ & $\mathrm{~d}_{2}$ & 0,2291 & 7,04 & 4 & 6,29 & & 0,1545 & 151,76 \\
\hline $\mathrm{CN}_{\mathrm{MIC}}$ & $\mathrm{d}_{0}$ & 0,7743 & 1,87 & 3 & 2,18 & 0,66 & 0,9012 & 49,38 \\
\hline $\mathrm{CN}_{\mathrm{MIC}}$ & $\mathrm{d}_{1}$ & 0,7949 & 1,79 & 4 & 1,82 & 0,71 & 0,8986 & 35,51 \\
\hline $\mathrm{CN}_{\text {MIC }}$ & $\mathrm{d}_{2}$ & 0,7510 & 1,95 & 3 & 2,51 & & 0,8567 & 55,01 \\
\hline COT & $\mathrm{d}_{0}$ & 0,7649 & 5,77 & 7 & 4,74 & 0,84 & 0,9519 & 26,07 \\
\hline $\mathrm{COT}$ & $\mathrm{d}_{1}$ & 0,6913 & 6,44 & 5 & 9,31 & 0,70 & 0,8796 & 41,36 \\
\hline $\mathrm{COT}$ & $\mathrm{d}_{2}$ & 0,4222 & 8,19 & 4 & 18,97 & 0,26 & 0,4689 & 64,70 \\
\hline qMIC & $\mathrm{d}_{0}$ & 0,4179 & 3,86 & 4 & 11,21 & 0,03 & 0,2041 & 51,20 \\
\hline qMIC & $\mathrm{d}_{1}$ & 0,2073 & 4,11 & 1 & 11,73 & $-0,02$ & $-0,2590$ & 53,75 \\
\hline qMIC & $\mathrm{d}_{2}$ & 0,1589 & 4,16 & 1 & 11,54 & $-0,02$ & $-0,2519$ & 51,89 \\
\hline
\end{tabular}




\section{ANEXO III}

Resultados de validação cruzada e validação externa referentes aos modelos de calibração em DRIFTS para o grupo amostral TODOS sem transformação dos dados e com a $1^{\mathrm{a}}$ e $2^{\mathrm{a}}$ derivadas

\begin{tabular}{|c|c|c|c|c|c|c|c|c|}
\hline & Transformação & RVC & SEV & $\mathrm{n}^{0}$ de fatores & Intecepto & Inclinação & RVE & Erro $(\%)$ \\
\hline $\mathrm{C}_{\mathrm{MIC}}$ & $\mathrm{d}_{0}$ & 170,01 & 0,3156 & 6 & 221,94 & 0,31 & 0,3937 & 77,64 \\
\hline $\mathrm{C}_{\mathrm{MIC}}$ & $\mathrm{d}_{1}$ & 165,64 & 0,3958 & 5 & 223,13 & 0,29 & 0,3626 & 72,29 \\
\hline $\mathrm{C}_{\mathrm{MIC}}$ & $\mathrm{d}_{2}$ & 170,10 & 0,3354 & 5 & 265,09 & 0,17 & 0,2023 & 84,67 \\
\hline $\mathrm{N}_{\mathrm{MIC}}$ & $\mathrm{d}_{0}$ & 51,17 & 0,5363 & 3 & 48,48 & 0,29 & 0,5696 & 82,13 \\
\hline $\mathrm{N}_{\mathrm{MIC}}$ & $\mathrm{d}_{1}$ & 52,19 & 0,5751 & 6 & 33,80 & 0,44 & 0,6402 & 63,30 \\
\hline $\mathrm{N}_{\mathrm{MIC}}$ & $\mathrm{d}_{2}$ & 53,88 & 0,5182 & 5 & 37,72 & 0,43 & 0,6670 & 67,83 \\
\hline $\mathrm{RB}$ & $\mathrm{d}_{0}$ & 1,20 & 0,6082 & 7 & 0,98 & 0,44 & 0,7144 & 79,79 \\
\hline $\mathrm{RB}$ & $\mathrm{d}_{1}$ & 1,29 & 0,5280 & 6 & 0,96 & 0,43 & 0,6171 & 84,28 \\
\hline $\mathrm{RB}$ & $\mathrm{d}_{2}$ & 1,34 & 0,4951 & 7 & 0,89 & 0,44 & 0,6428 & 78,16 \\
\hline $\mathrm{qCO}_{2}$ & $\mathrm{~d}_{0}$ & 5,20 & 0,4719 & 5 & 6,17 & 0,12 & 0,3624 & 70,35 \\
\hline $\mathrm{qCO}_{2}$ & $\mathrm{~d}_{1}$ & 5,52 & 0,3676 & 5 & 6,05 & 0,11 & 0,2754 & 84,94 \\
\hline $\mathrm{qCO}_{2}$ & $\mathrm{~d}_{2}$ & 5,54 & 0,3836 & 5 & 6,31 & 0,07 & 0,2252 & 78,95 \\
\hline $\mathrm{CN}_{\text {MIC }}$ & $\mathrm{d}_{0}$ & 2,51 & 0,5411 & 5 & 5,29 & 0,07 & 0,2815 & 69,17 \\
\hline $\mathrm{CN}_{\text {MIC }}$ & $\mathrm{d}_{1}$ & 2,71 & 0,4648 & 6 & 5,30 & 0,09 & 0,3603 & 69,09 \\
\hline $\mathrm{CN}_{\mathrm{MIC}}$ & $\mathrm{d}_{2}$ & 2,60 & 0,5046 & 4 & 5,45 & 0,06 & 0,2714 & 76,15 \\
\hline $\mathrm{COT}$ & $\mathrm{d}_{0}$ & 7,45 & 0,6026 & 6 & 15,03 & 0,46 & 0,5890 & 28,10 \\
\hline COT & $\mathrm{d}_{1}$ & 7,80 & 0,5595 & 5 & 15,92 & 0,42 & 0,5054 & 30,15 \\
\hline $\mathrm{COT}$ & $\mathrm{d}_{2}$ & 8,02 & 0,5227 & 3 & 19,34 & 0,29 & 0,4052 & 36,68 \\
\hline qMIC & $\mathrm{d}_{0}$ & 7,00 & 0,1243 & 6 & 10,05 & 0,06 & 0,2931 & 77,30 \\
\hline qMIC & $\mathrm{d}_{1}$ & 7,01 & 0,1254 & 10 & 10,12 & 0,08 & 0,2758 & 77,74 \\
\hline qMIC & $\mathrm{d}_{2}$ & 7,17 & 0,0140 & 4 & 10,84 & 0,03 & 0,1661 & 75,34 \\
\hline
\end{tabular}

